Fall 1928

\title{
1928 Cedrus Yearbook
}

\section{Cedarville College}

Follow this and additional works at: https://digitalcommons.cedarville.edu/yearbooks

Part of the Higher Education Commons, Organizational Communication Commons, and the Public Relations and Advertising Commons

\section{Recommended Citation}

Cedarville College, "1928 Cedrus Yearbook" (1928). Yearbooks. 82.

https://digitalcommons.cedarville.edu/yearbooks/82

This Book is brought to you for free and open access by DigitalCommons@Cedarville, a service of the Centennial Library. It has been accepted for inclusion in Yearbooks by an authorized administrator of DigitalCommons@Cedarville. For more information, please contact digitalcommons@cedarville.edu. 


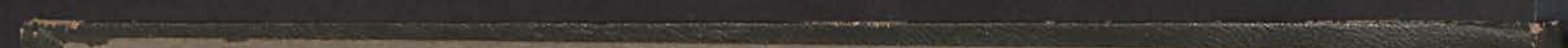

1

f:

I

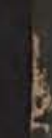




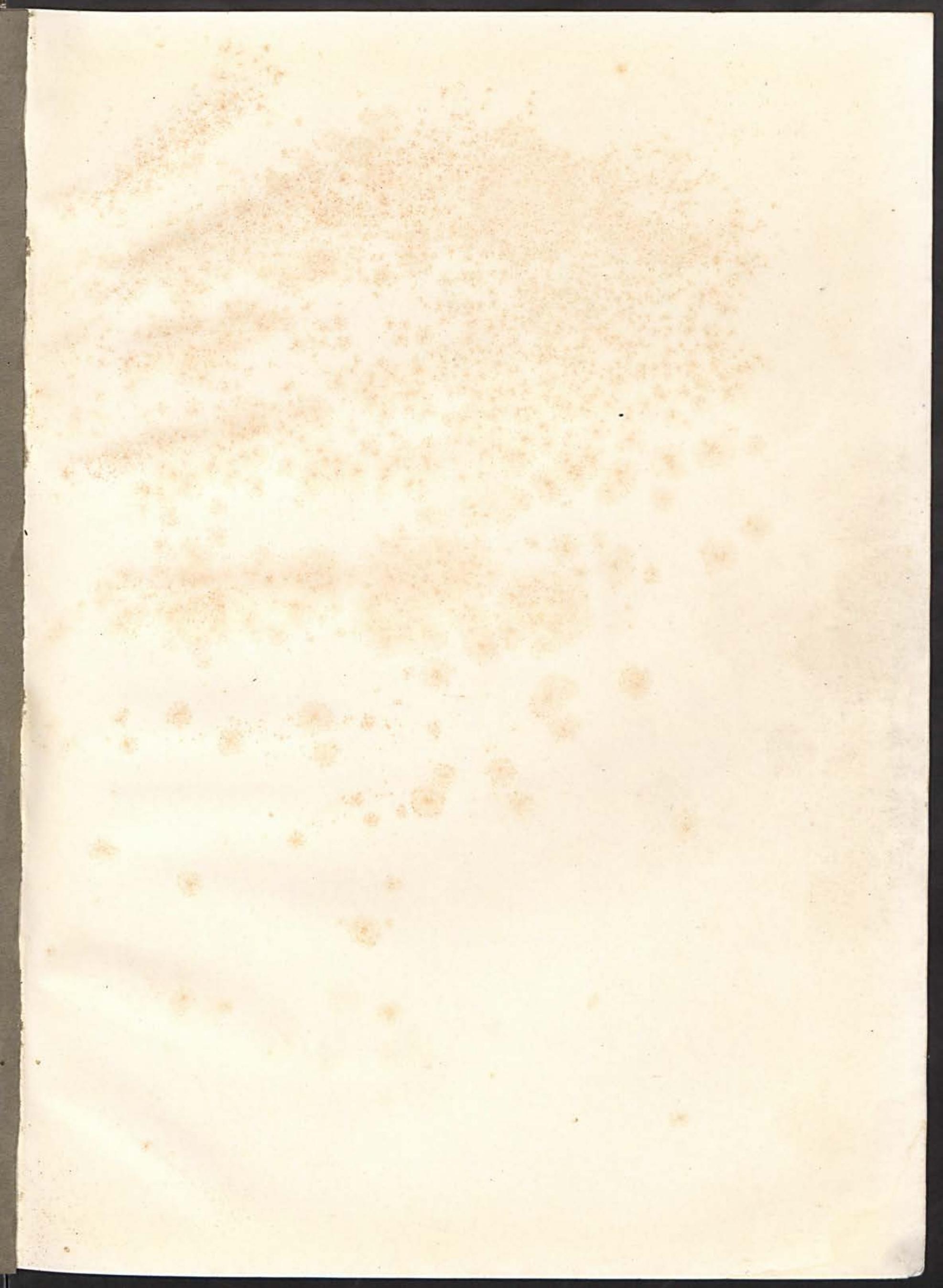



Orfe
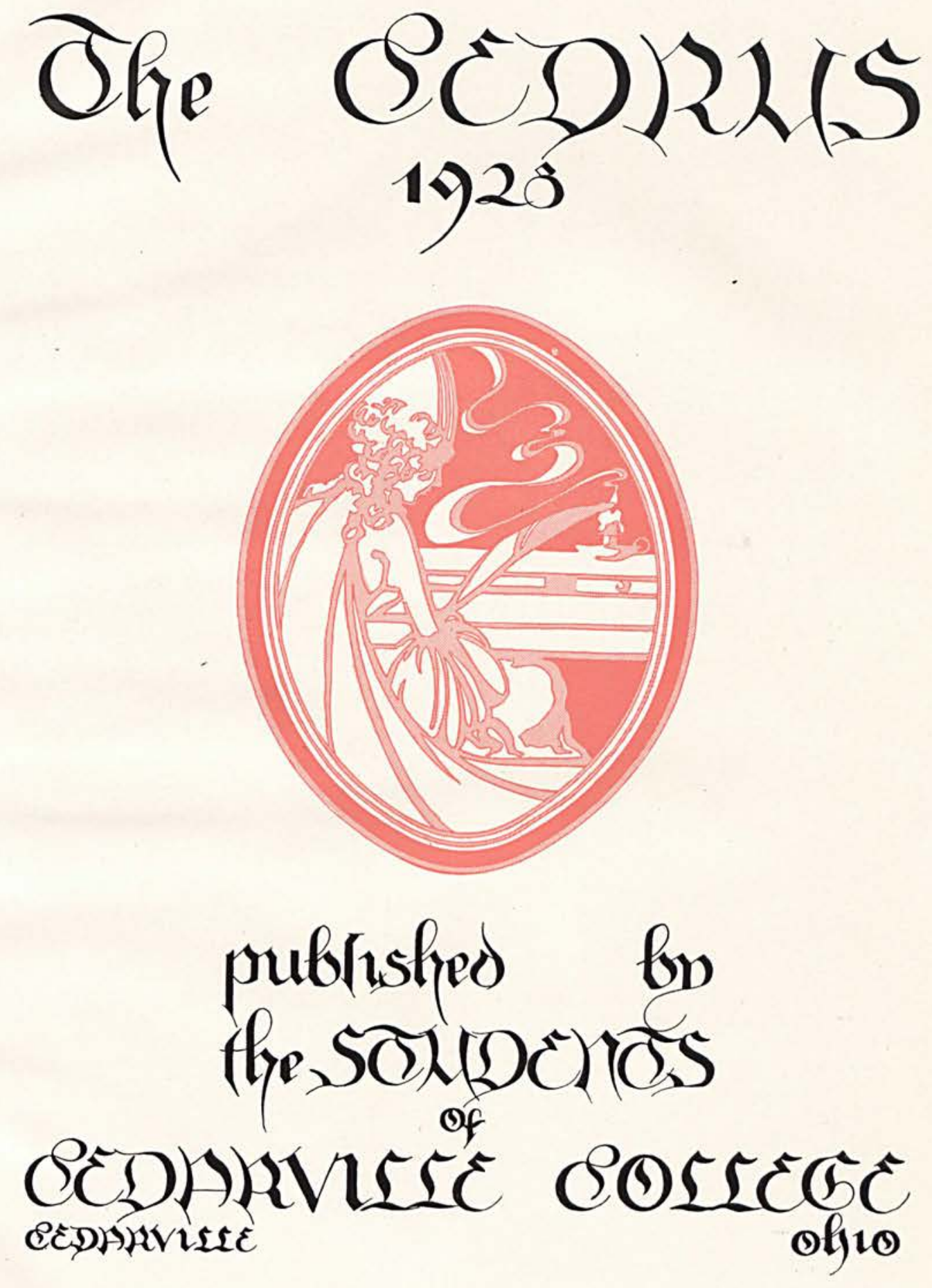


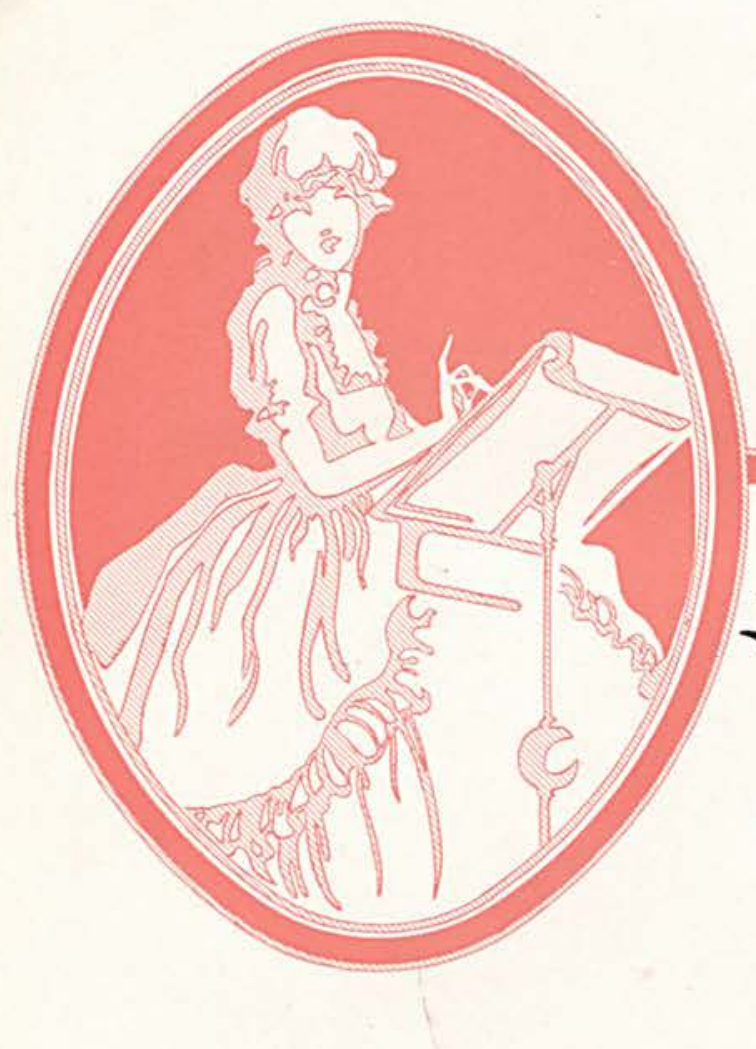

forenory

Avoruer year has pauxat. leaving its many memories, its failures and successes, its joys and disappointments. It is the privilege of the 1928 Cedrus Staff, in compiling the record and events of the past year, to place them against a background which will recall them to the fullest extent. For the recording of the greater occasions, words and pictures seem entirely inadequate. The strain of examinations, the excitement of the basketball season, the glory of the campus in spring-the impressions of these can be but poorly set down. It is hoped, however, that by recalling these high moments, the memory of the closing year will be kept forever fresh to those who have had a part in making this bit of history for our beloved Alma Mater. 


\section{(О) (ธE)}

I. THE COLLEGE

II. THE FACULTY

III. CLASSES

IV. ATHLETICS

V. ORGANIZATIONS

VI. ACTIVITIES 


\title{
取edication
}

\author{
To that Colonial spirit-the \\ spirit of achievement, which has \\ given us our heritage of ideals and \\ moral aims; the light which guides \\ toward firmness, yet fineness; the \\ spirit of originality in thought and \\ action; the spirit which has inspired \\ the highest accomplishments in all \\ types of American activity-the \\ Cedrus of 1928 is affectionately \\ dedicated.
}




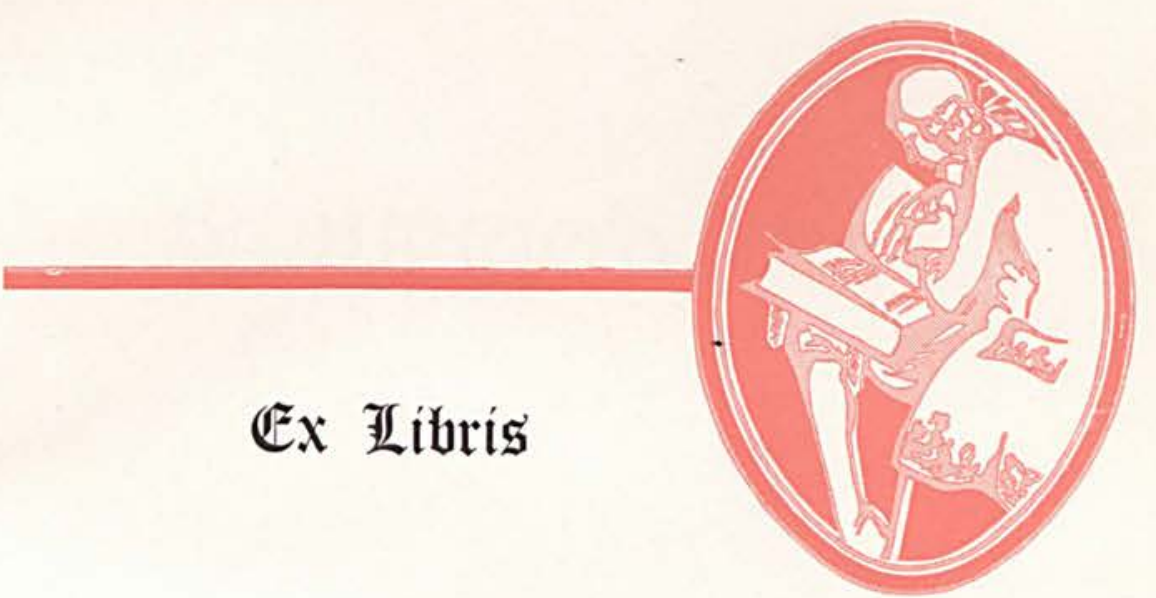




\section{coprris)}

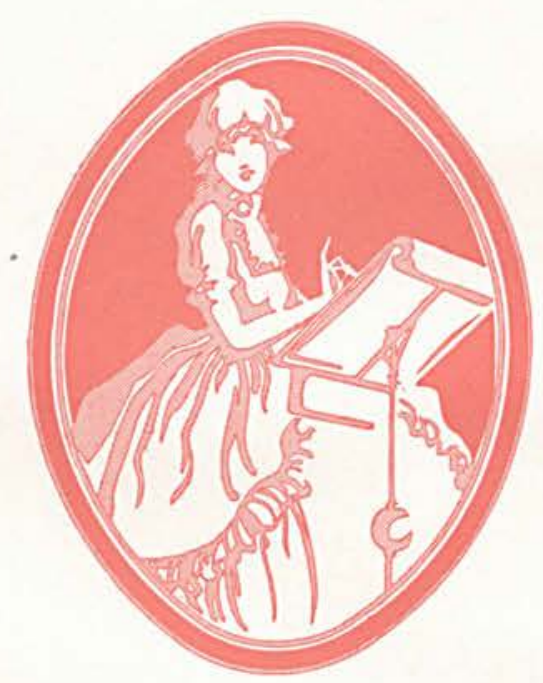

MARI WẼSCER

ebicor in eHicf

Jardes rórousan

BUSTIESS MATAAER 


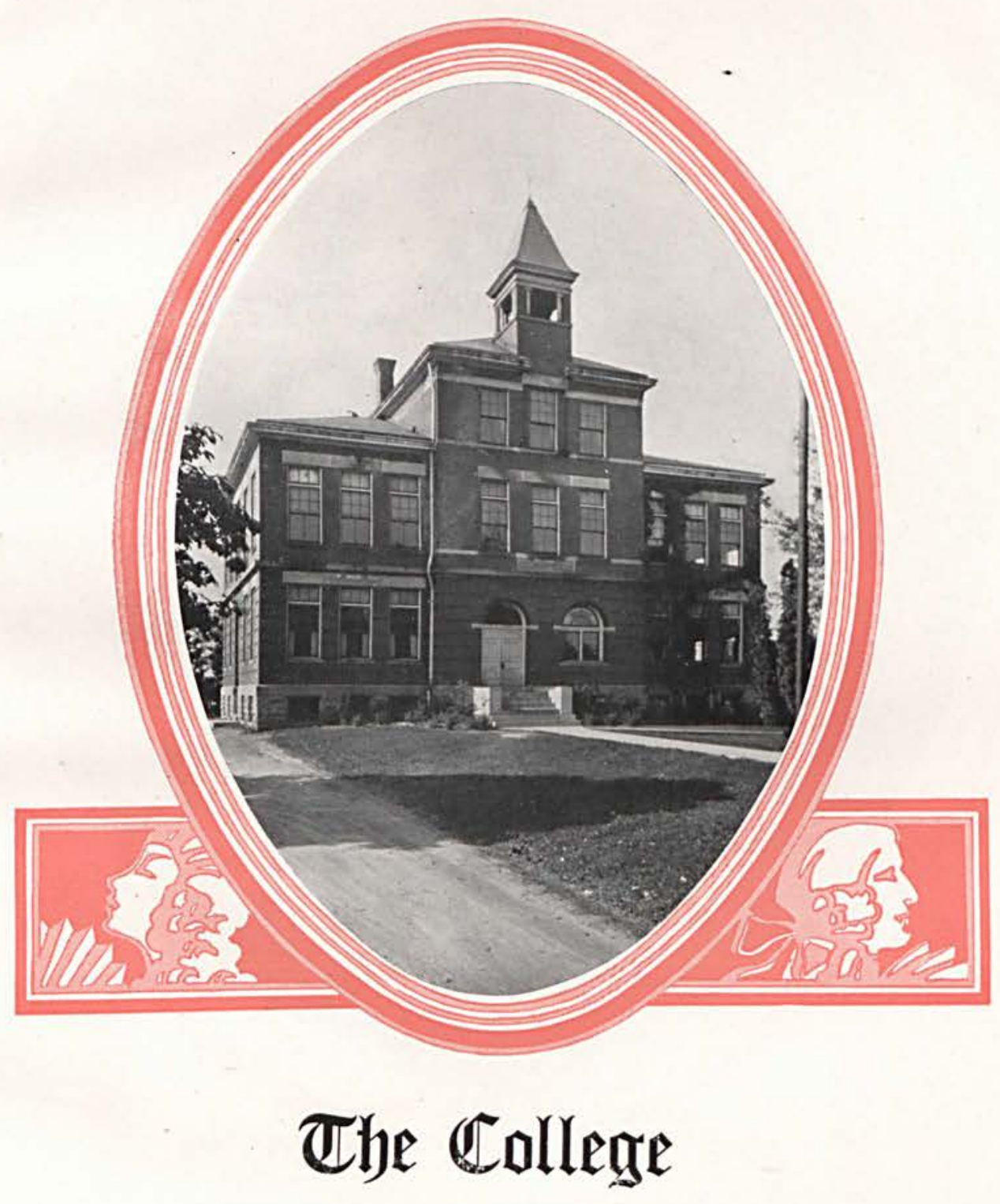




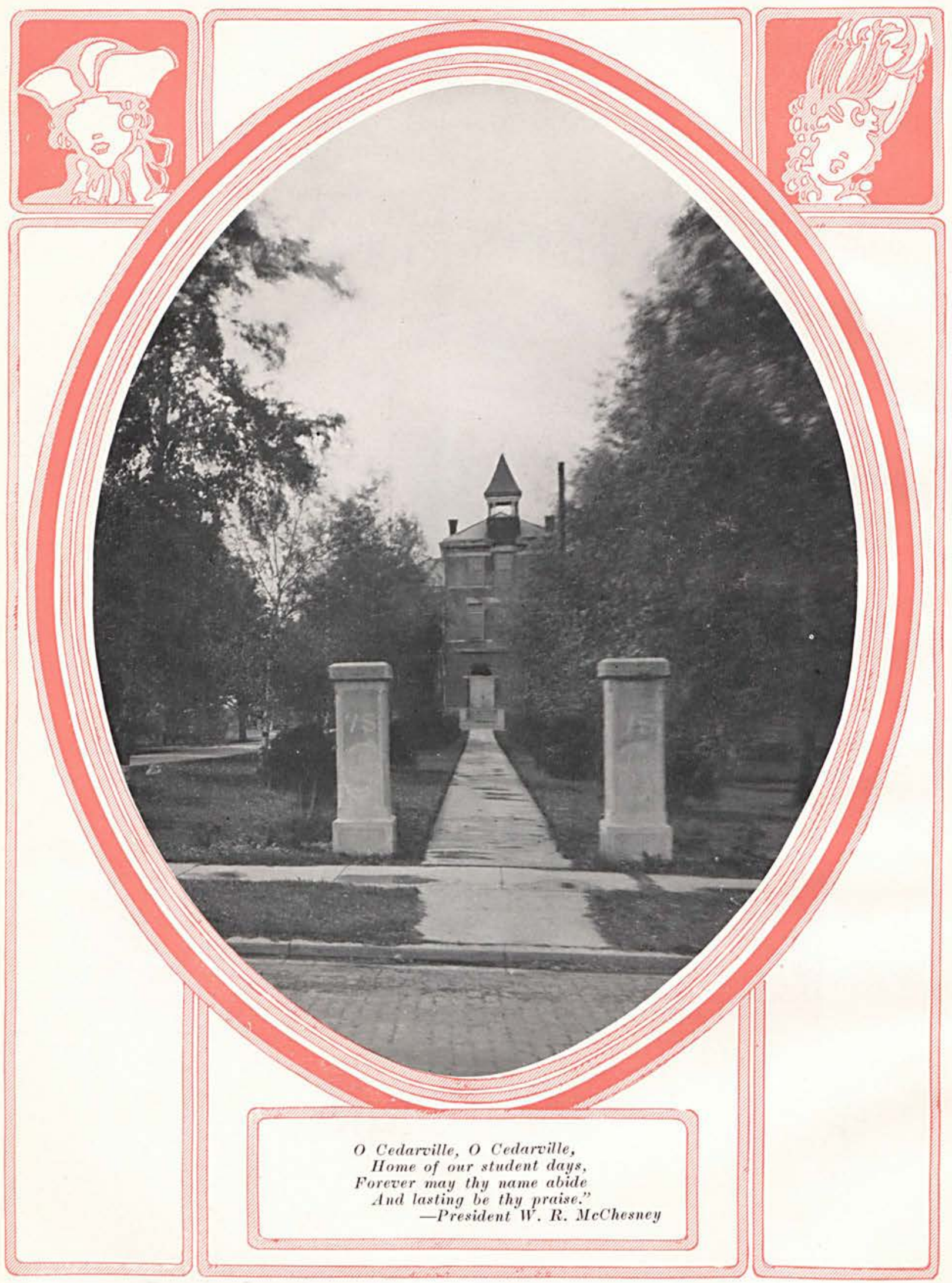




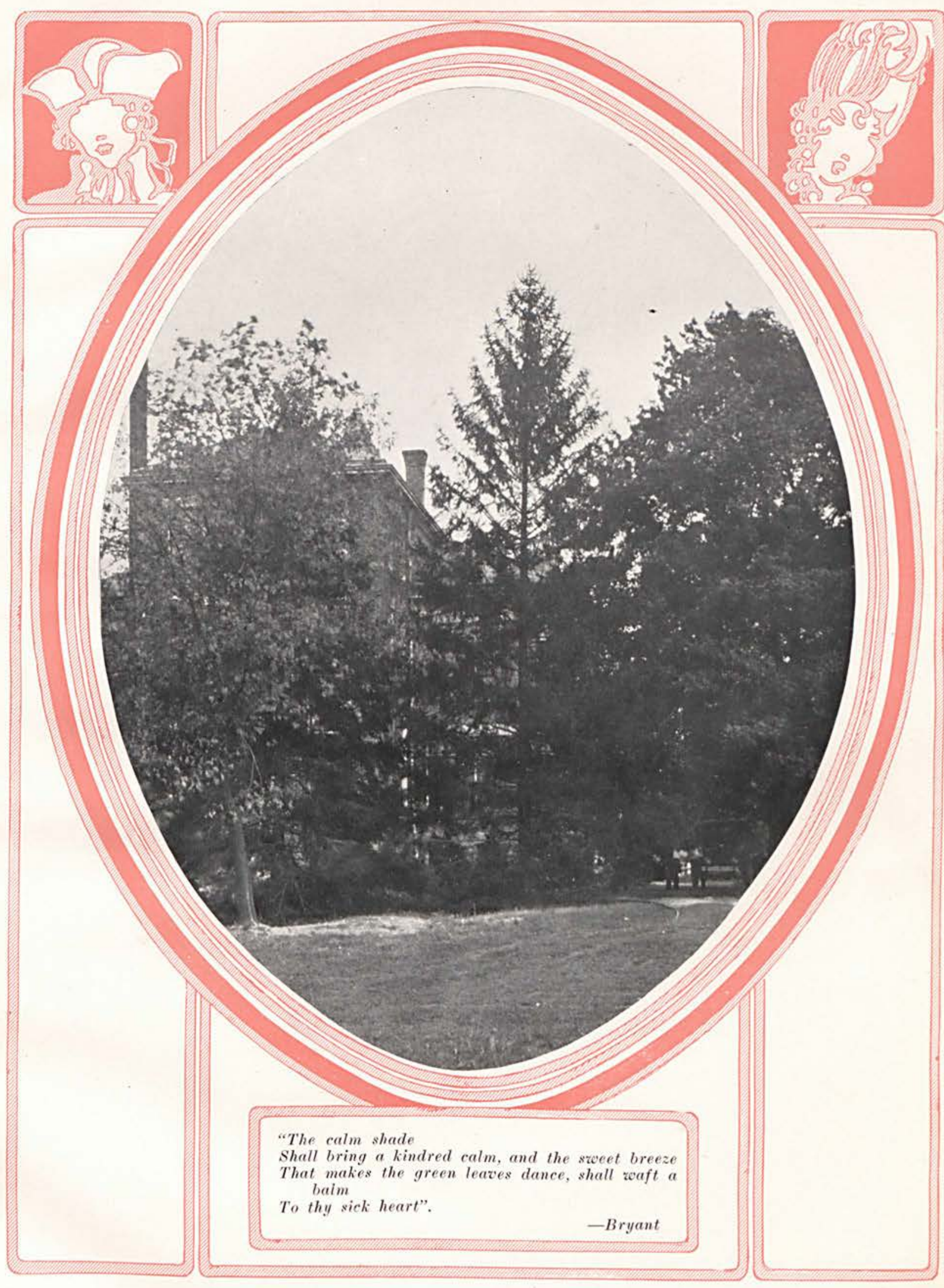




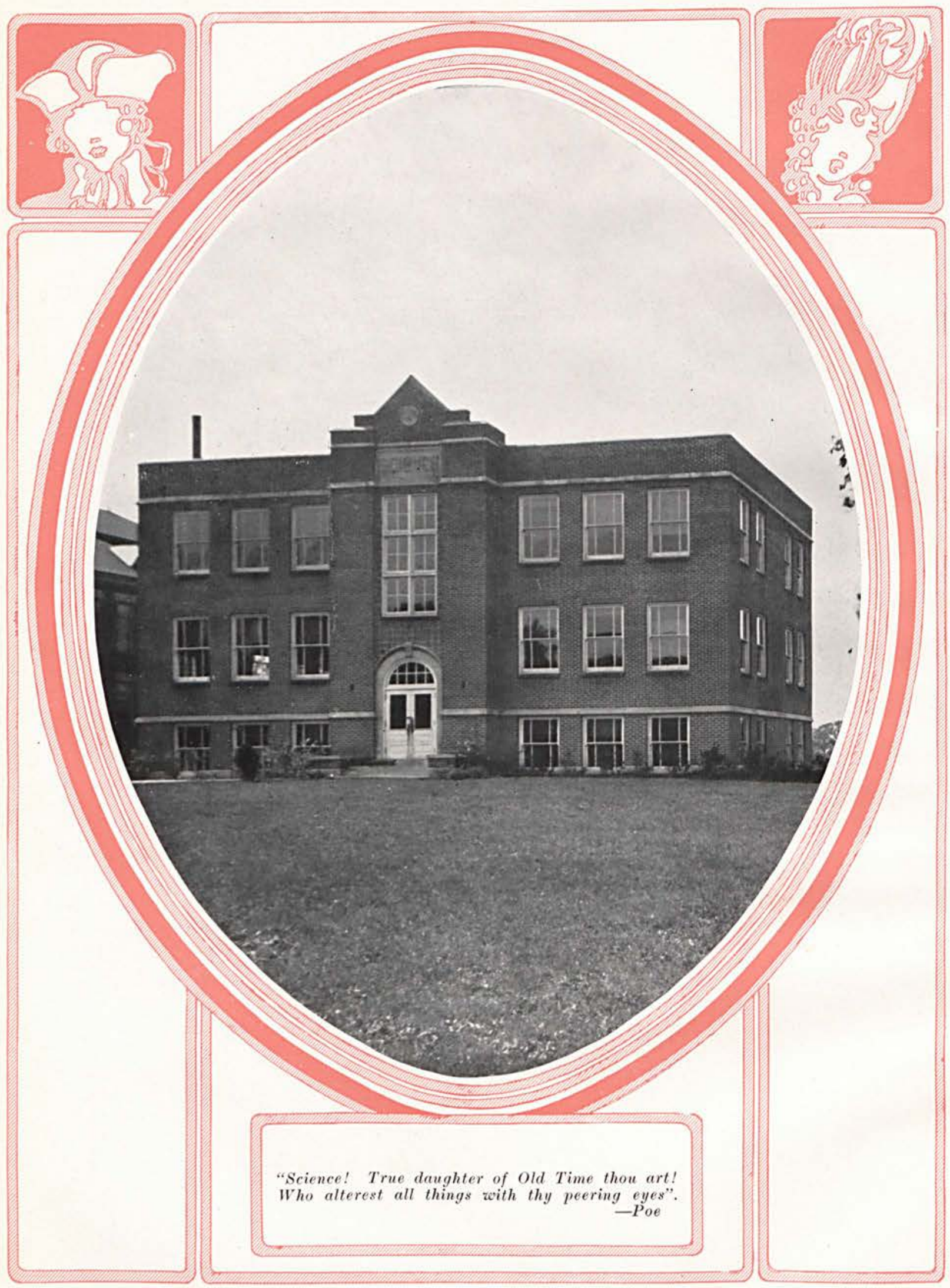




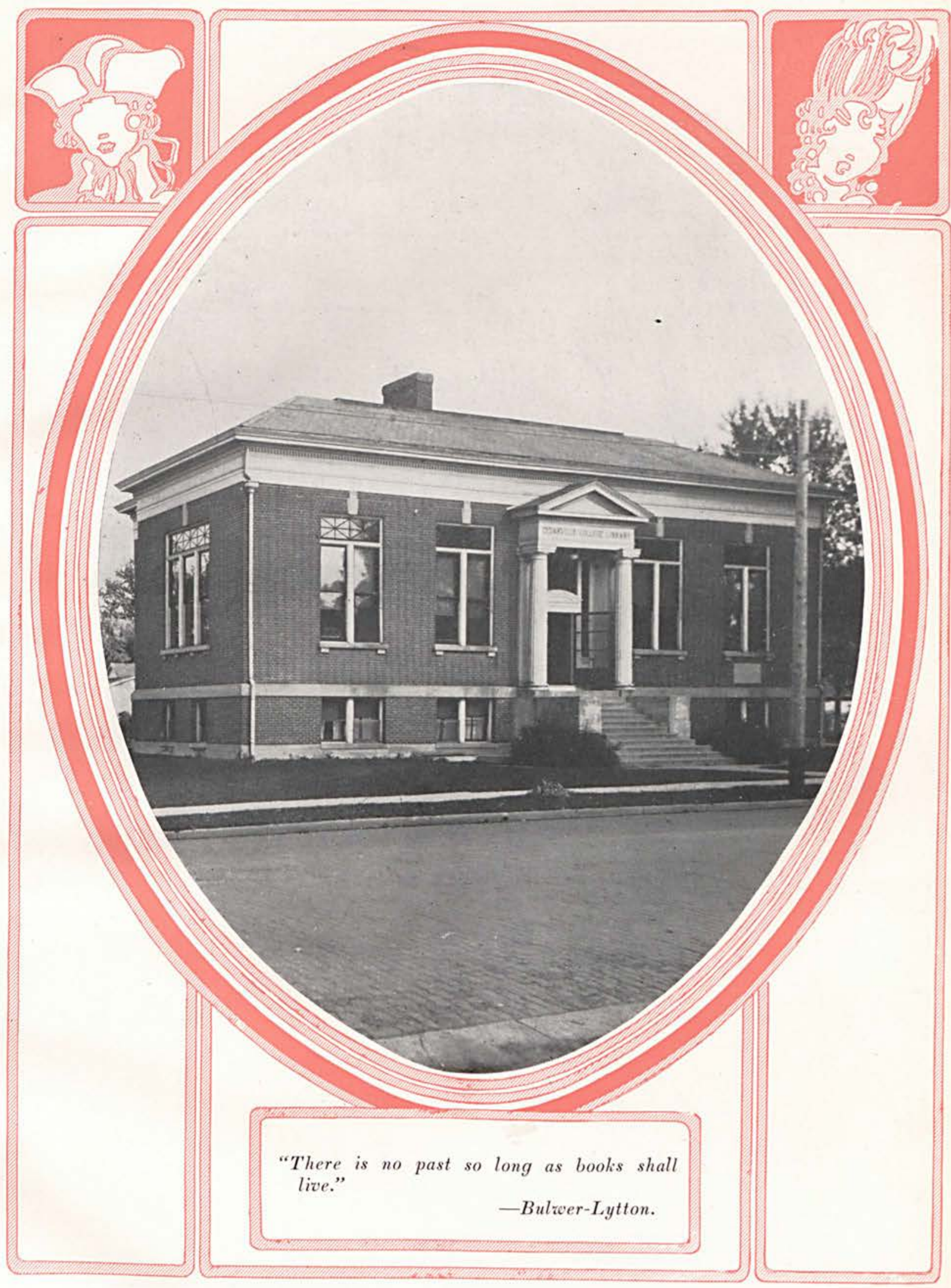




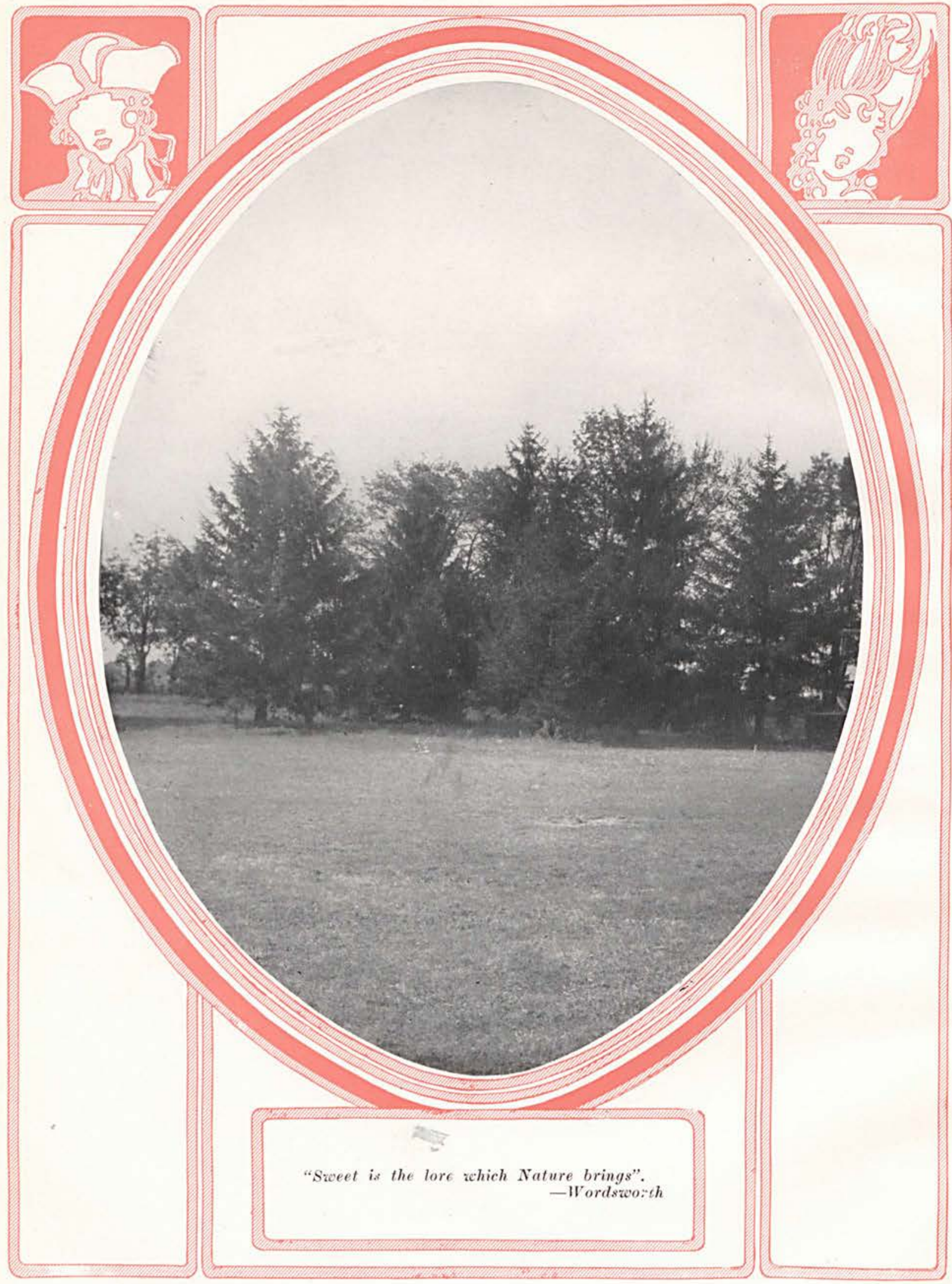




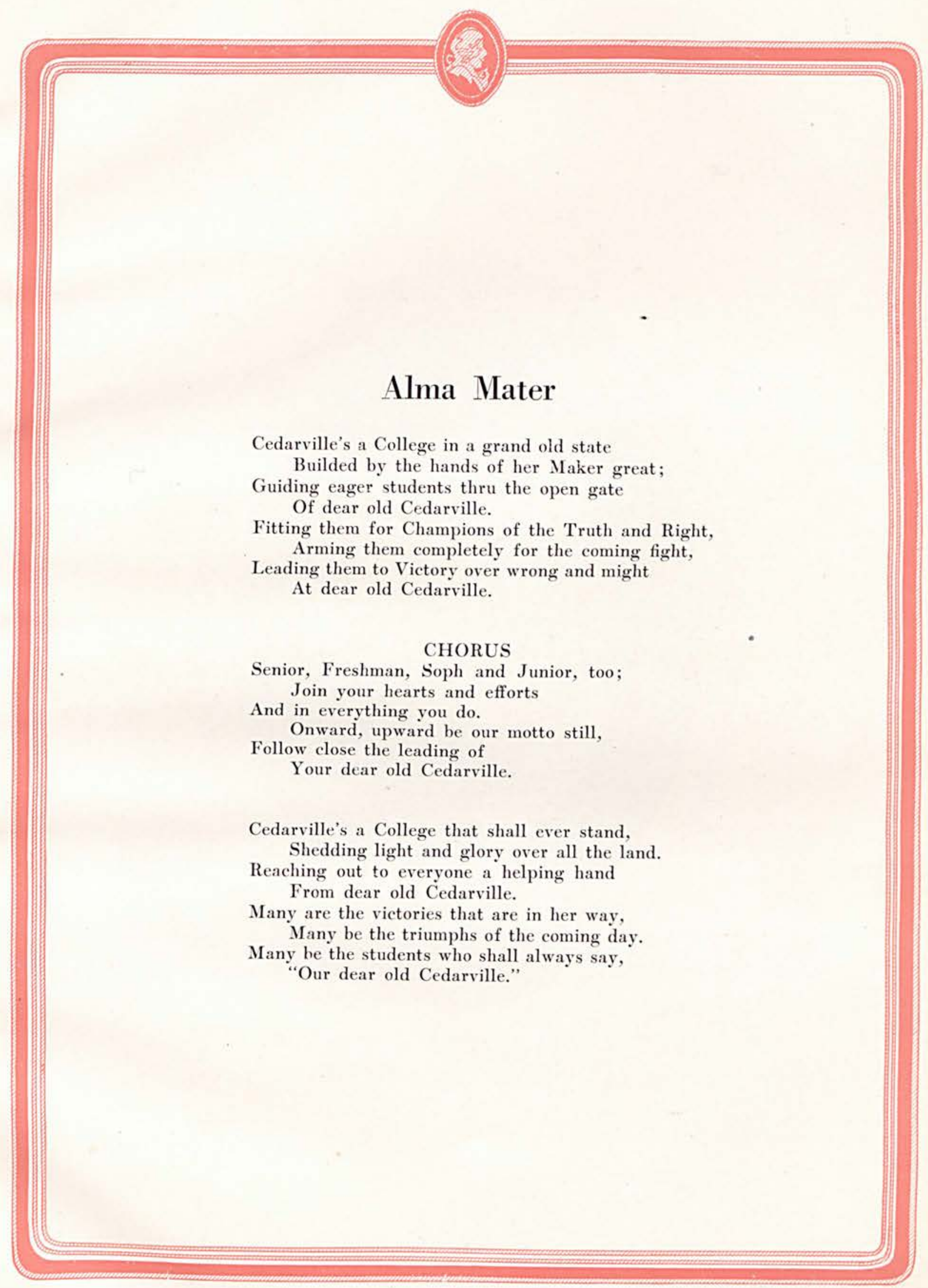

Page Thirteen 


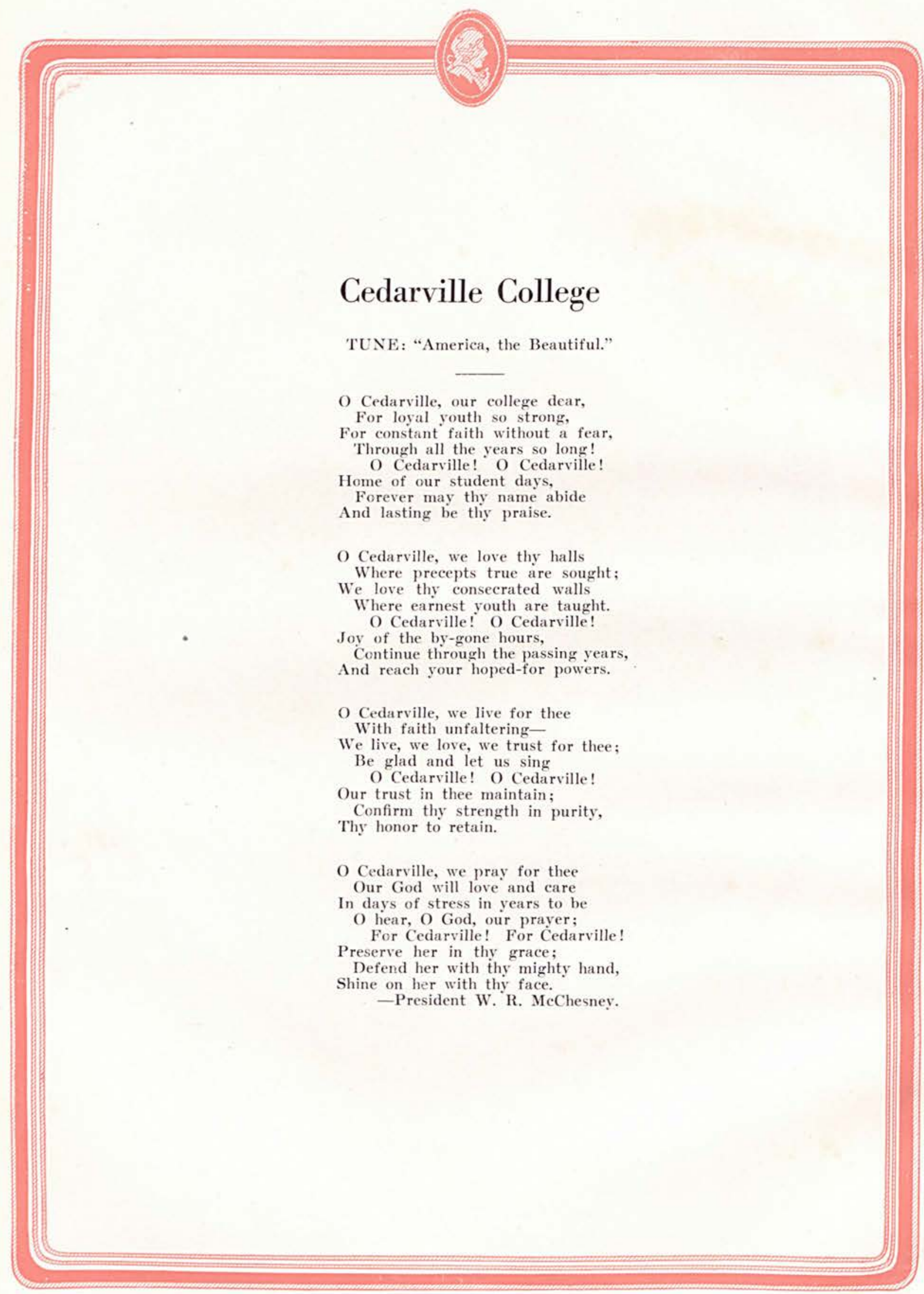

Page Fourteen 


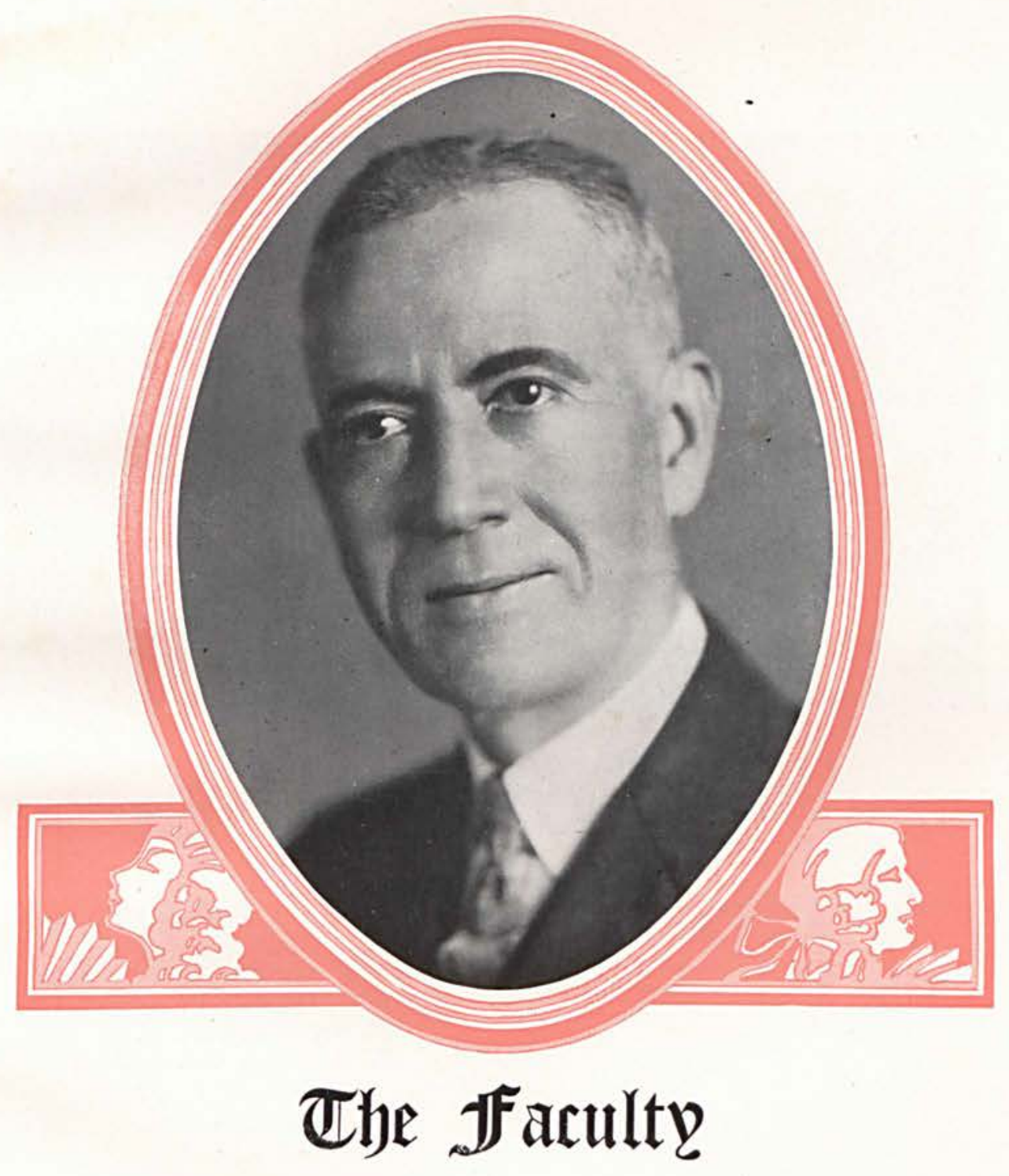




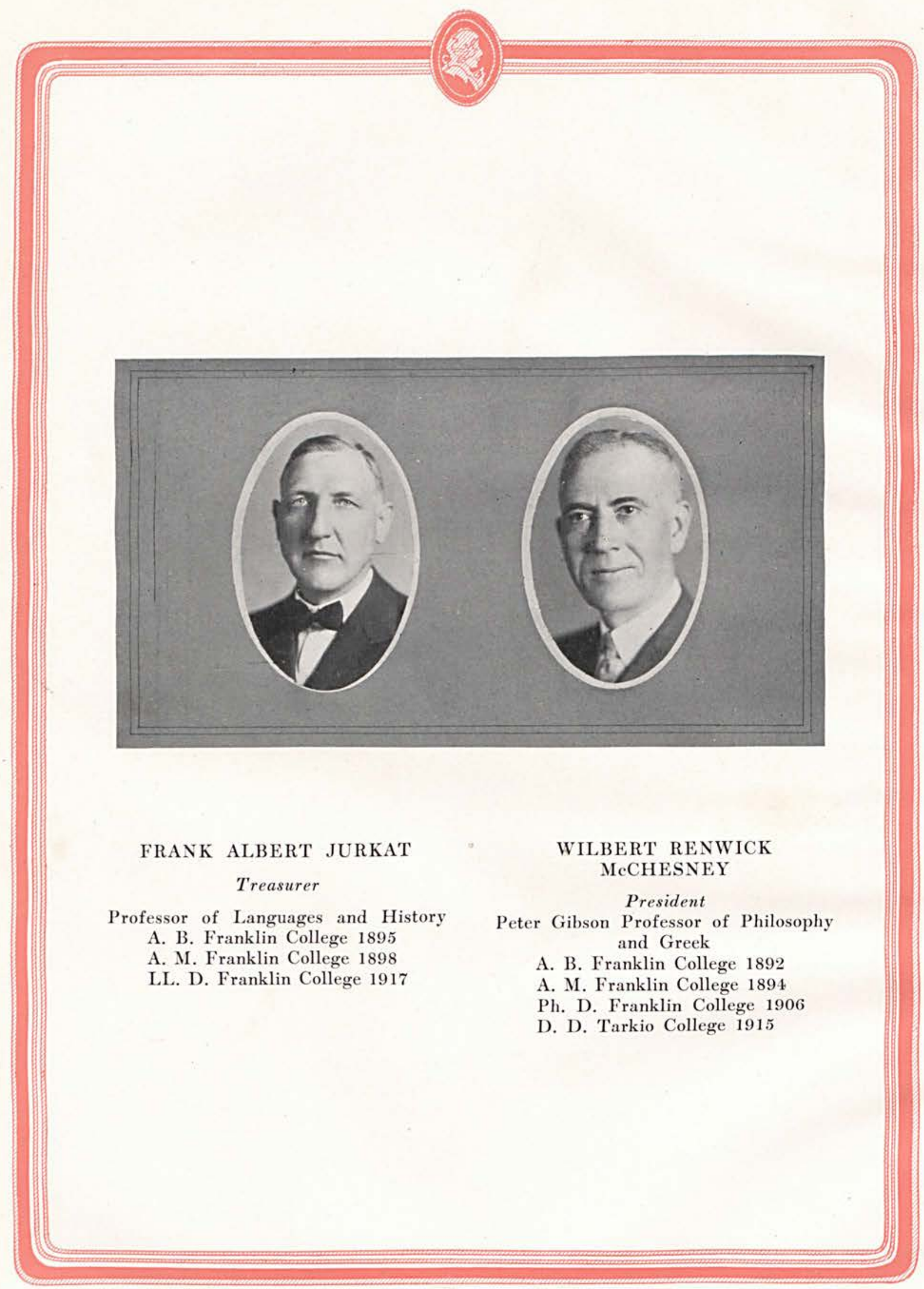

Page Sixteen 


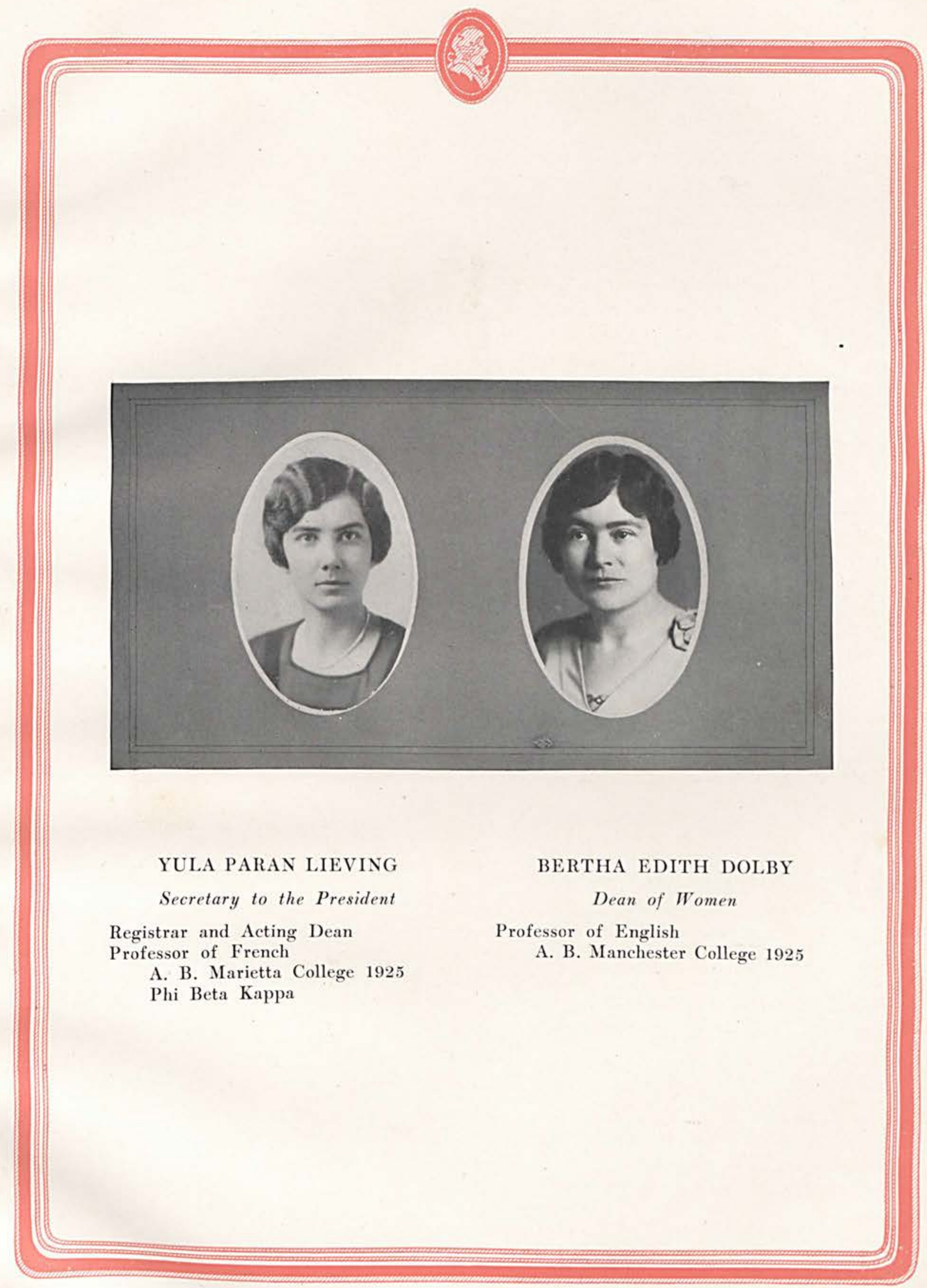

Page Seventeen 


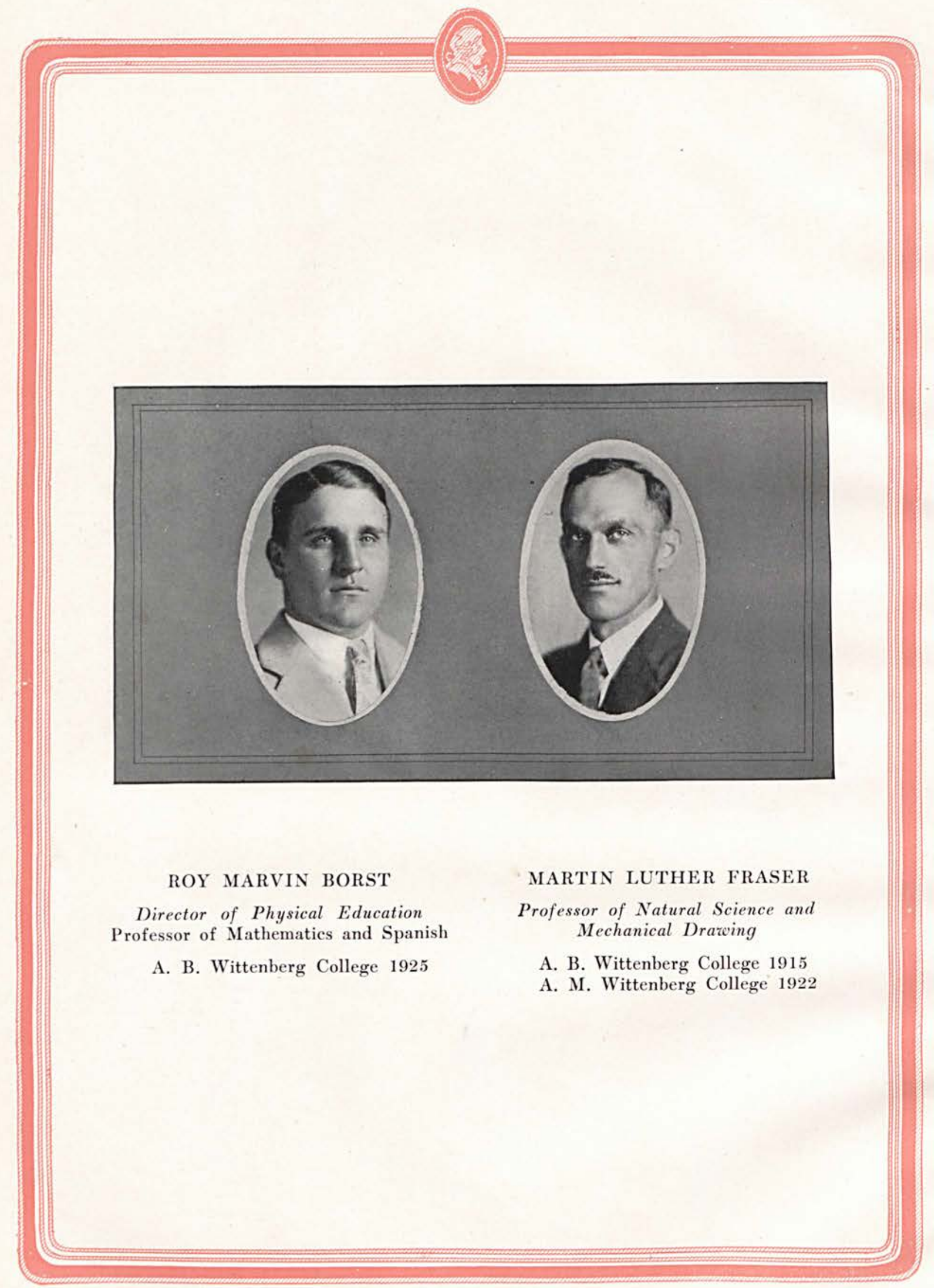

Page Eighteen 


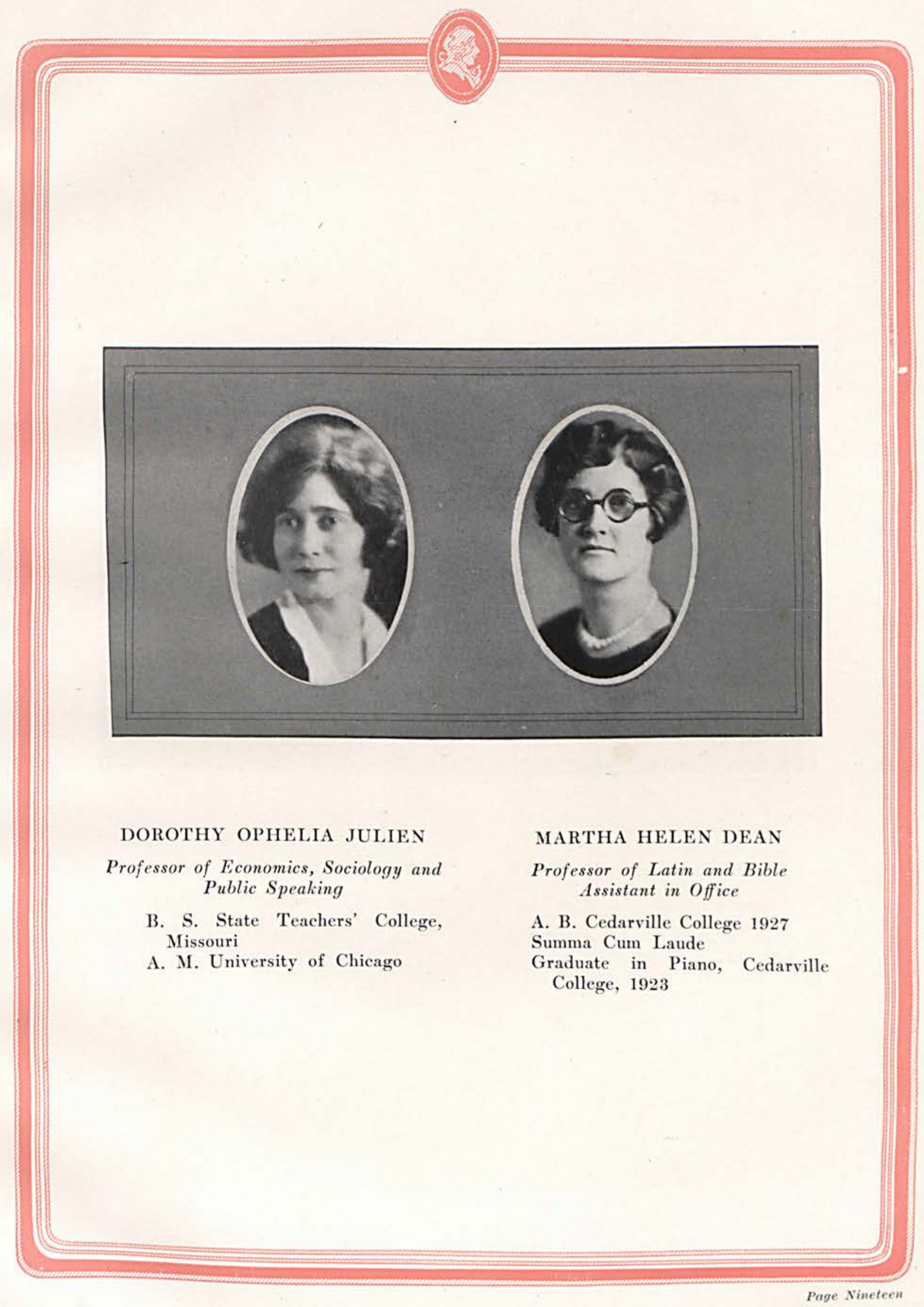




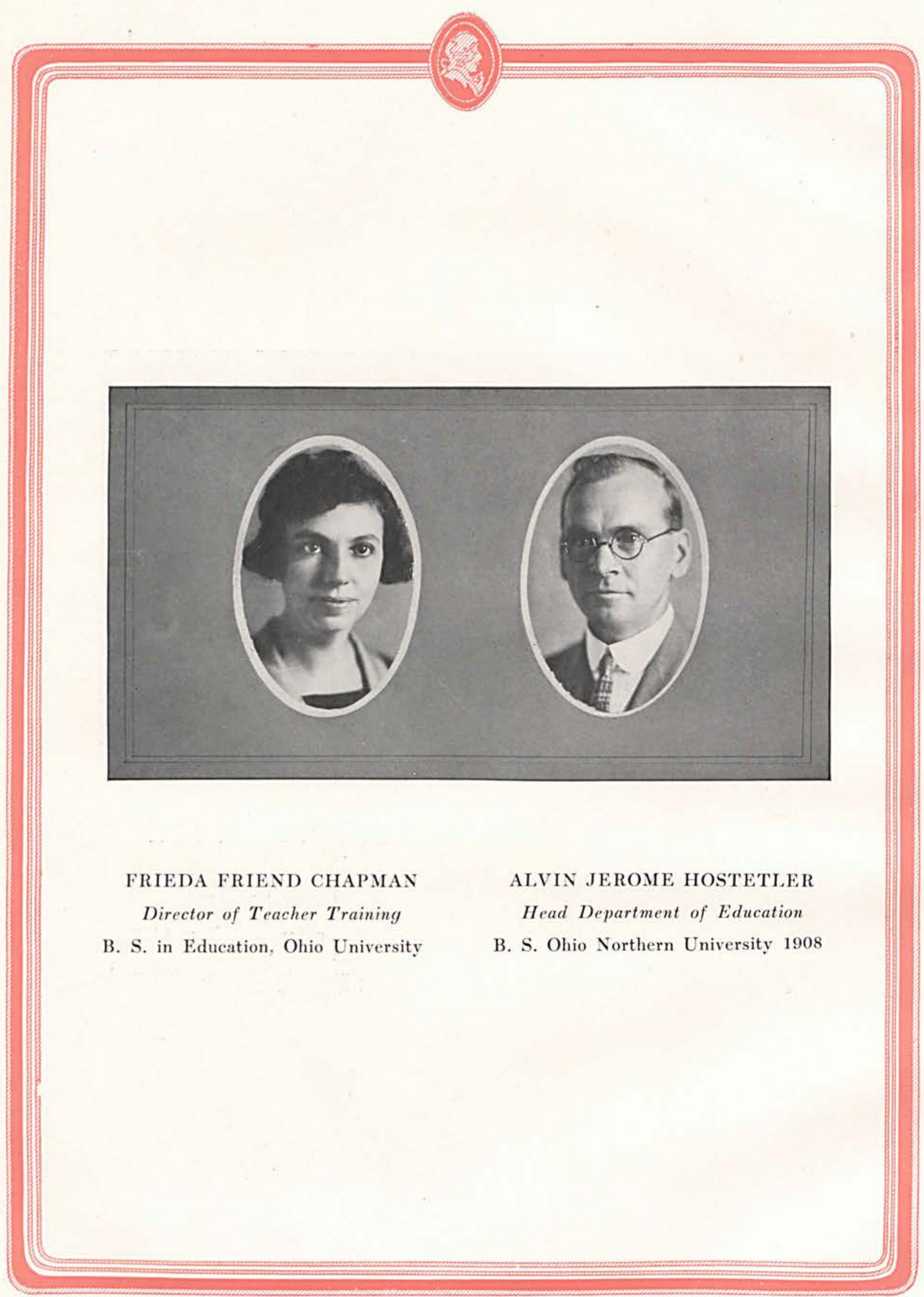

Page Twenty 


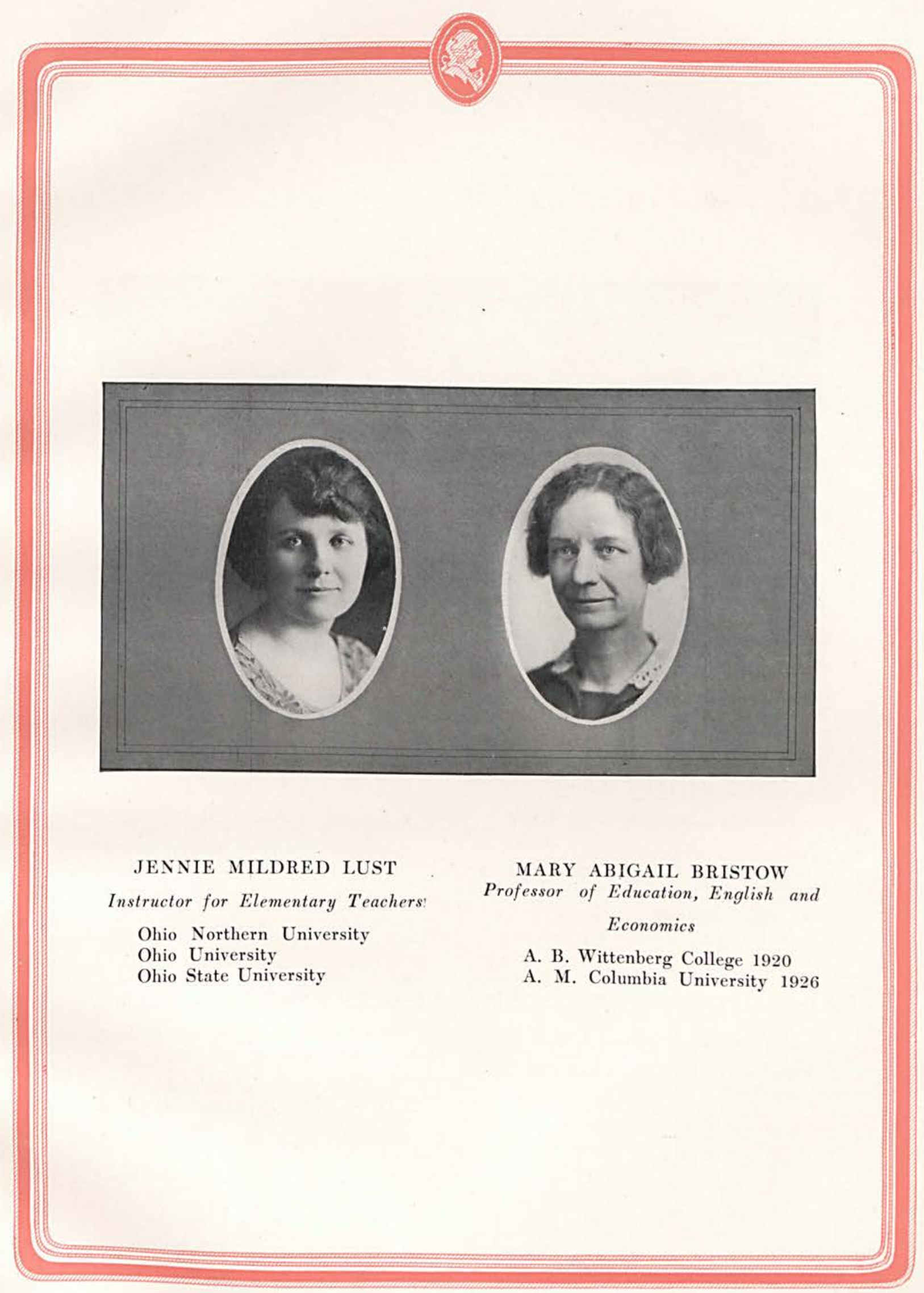

Page Twenty-one 


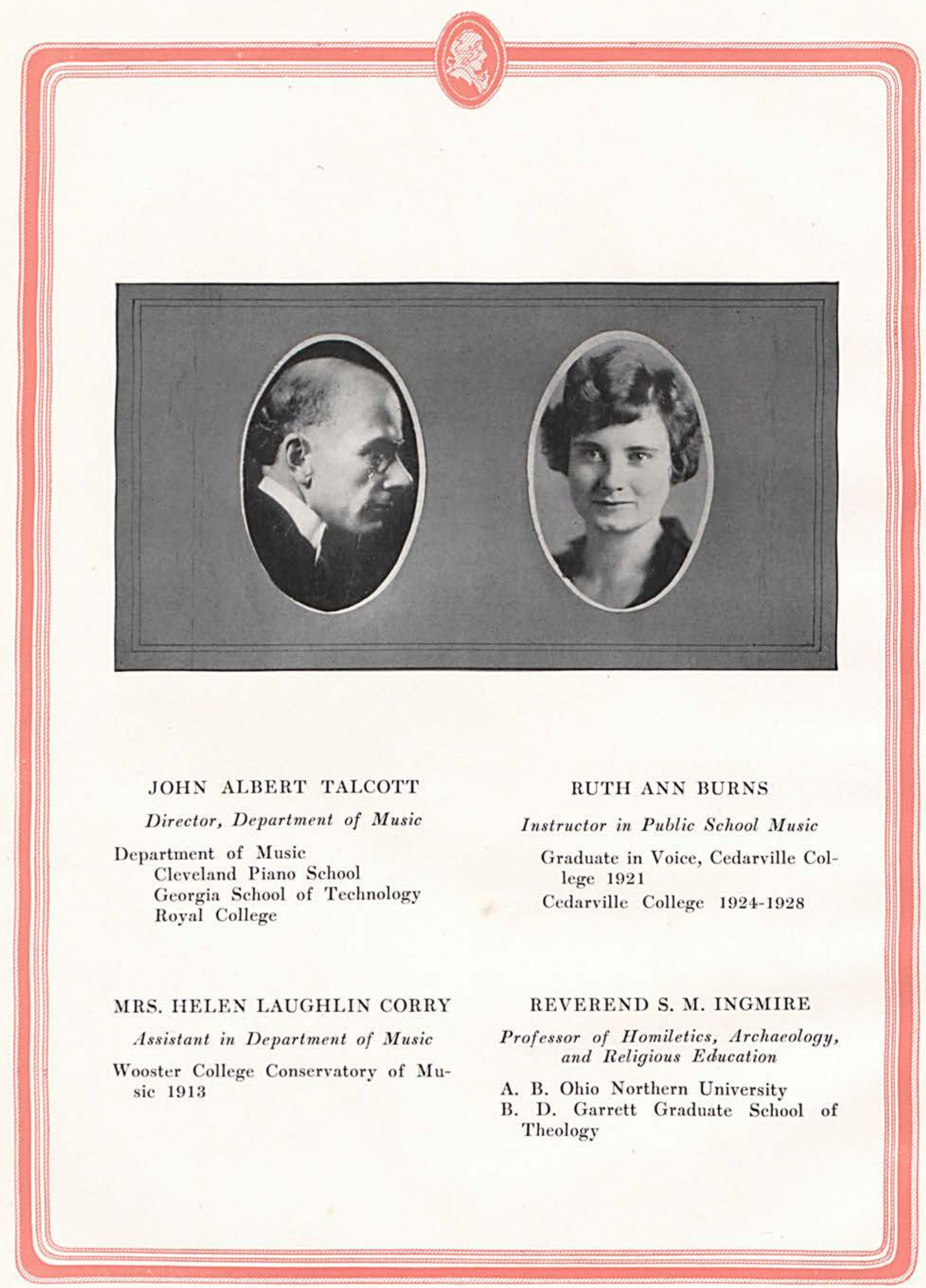

Page Twenty-two 


\section{Instructors and Assistants}

Gertrude Dooley Instructor in History

Ernest Gibson Assistant in Chemistry

Ernest Gibson Assistant in Physical Education

James Beam Assistant in Biology

Cecil Ewbank Instructor in Physics

James Stormont Instructor in Physics

Kenneth Little. Instructor in Saxophone

Lucile Tanner. Instructor in Plane Geometry

James Lemon Instructor in Plane Geometry

Helen Thompson Instructor in Algebra and Solid Geometry

Helen Thompson. Assistant in Office

Hilma Raisanen Assistant in Office

Edith Wigal Assistant in English

Viola Curry Instructor in English

Irene Shannon. Assistant in Physical Education

Charles Griffith Janitor 


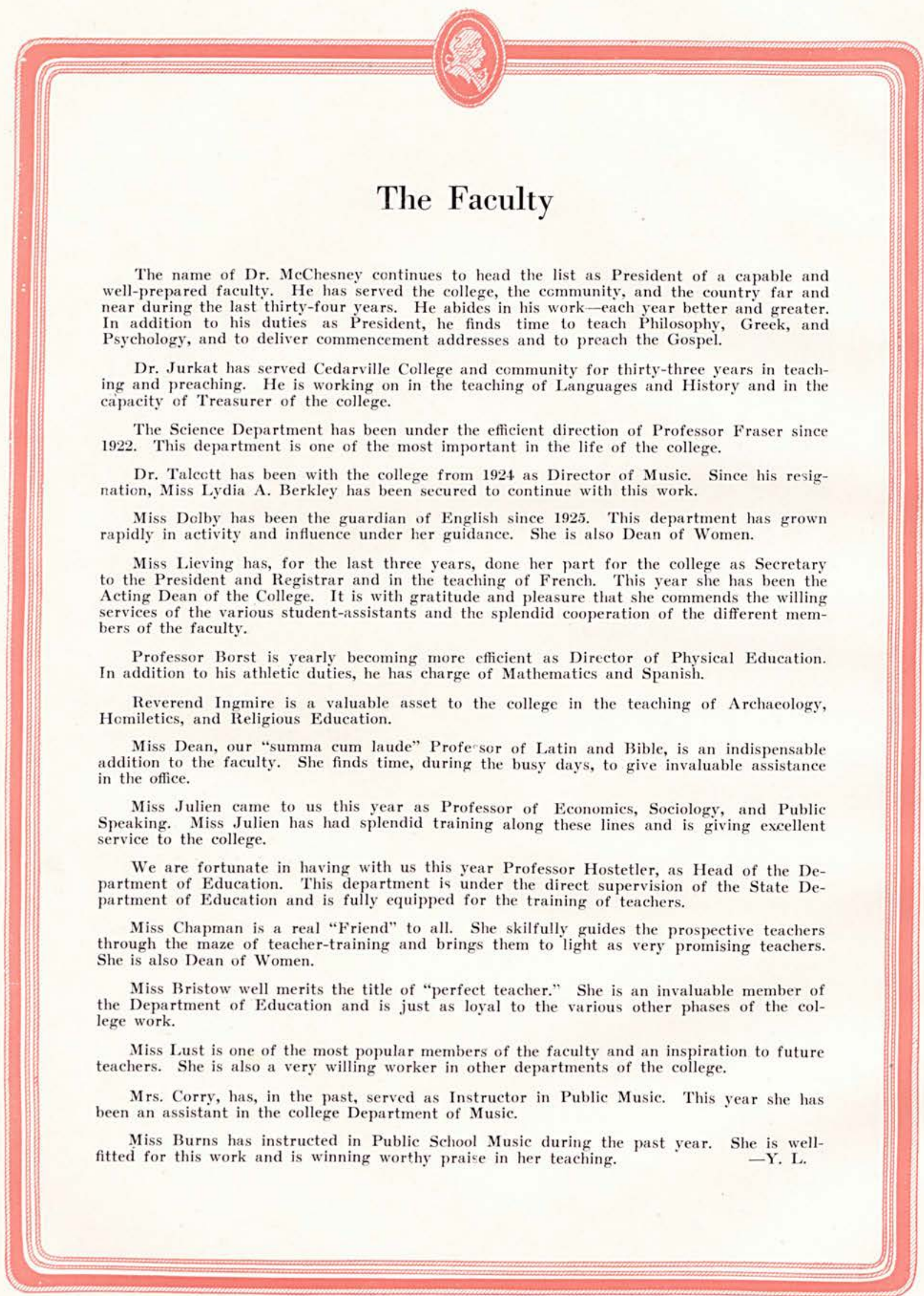

Page Twenty-four 


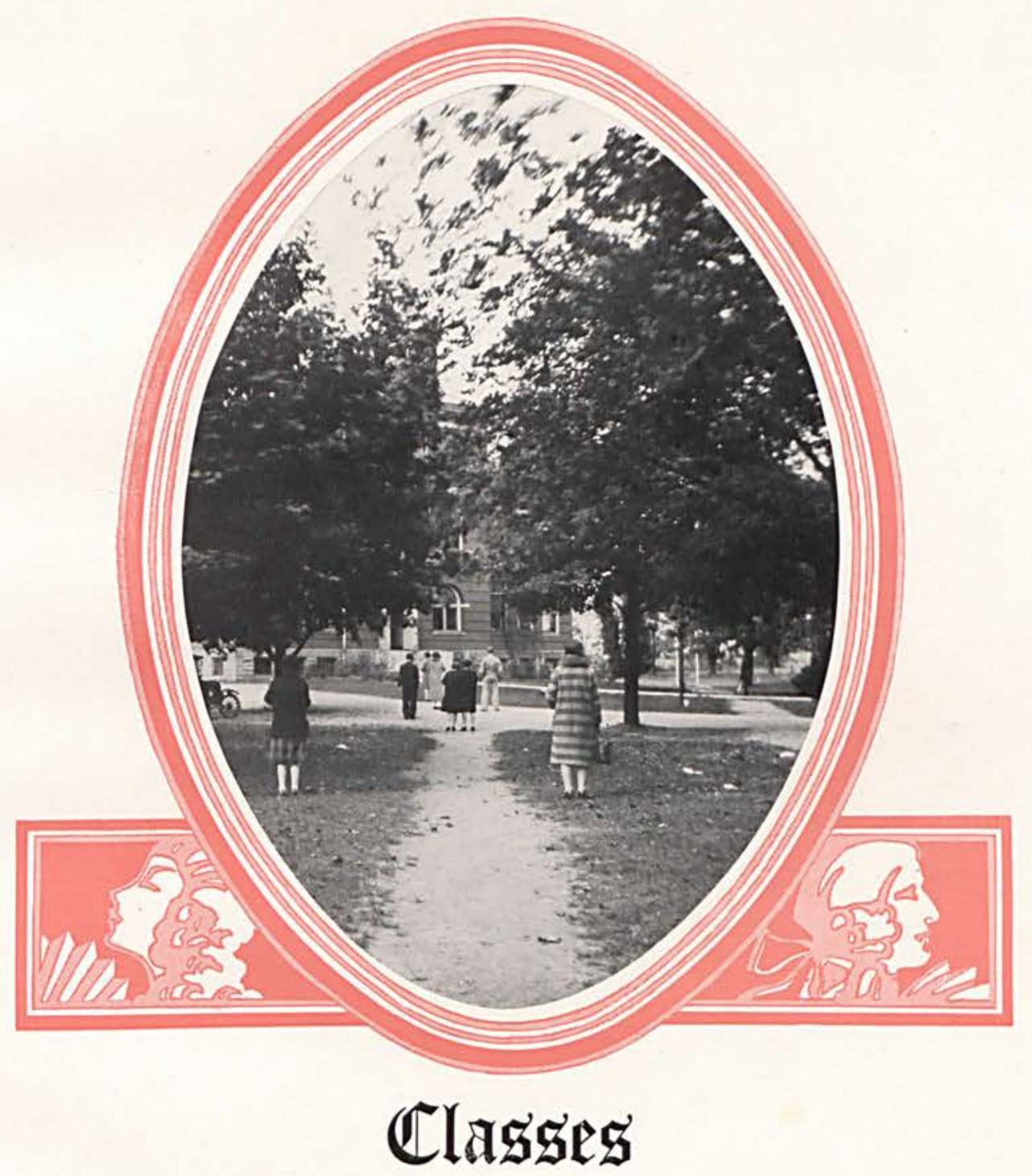




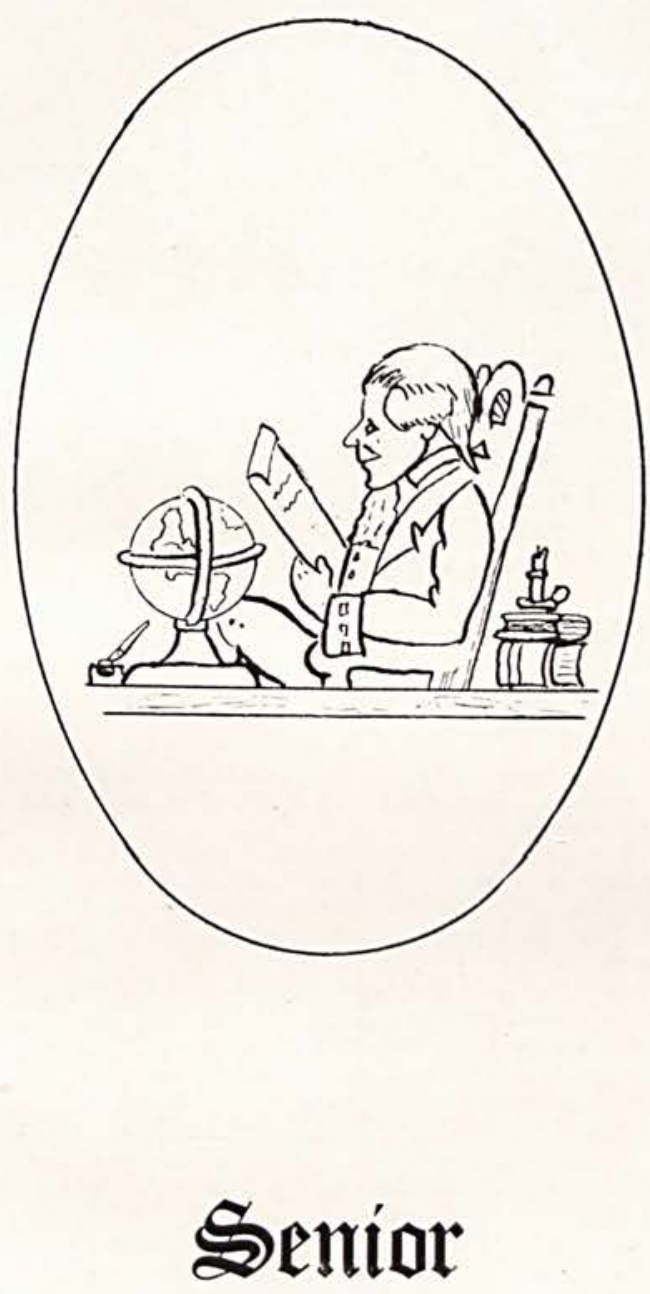

Page Twenty-seven 


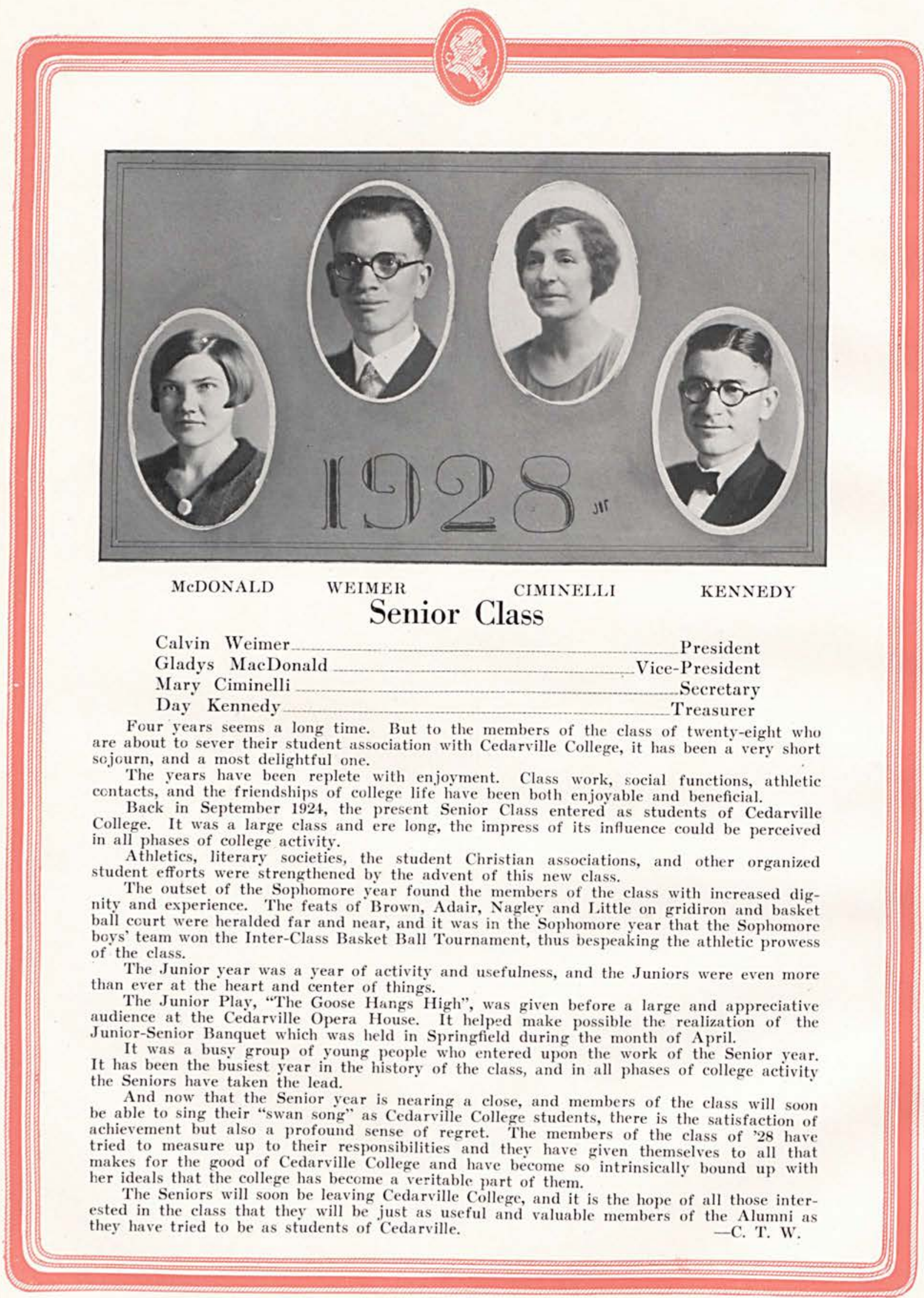

Page Twenty-eight 


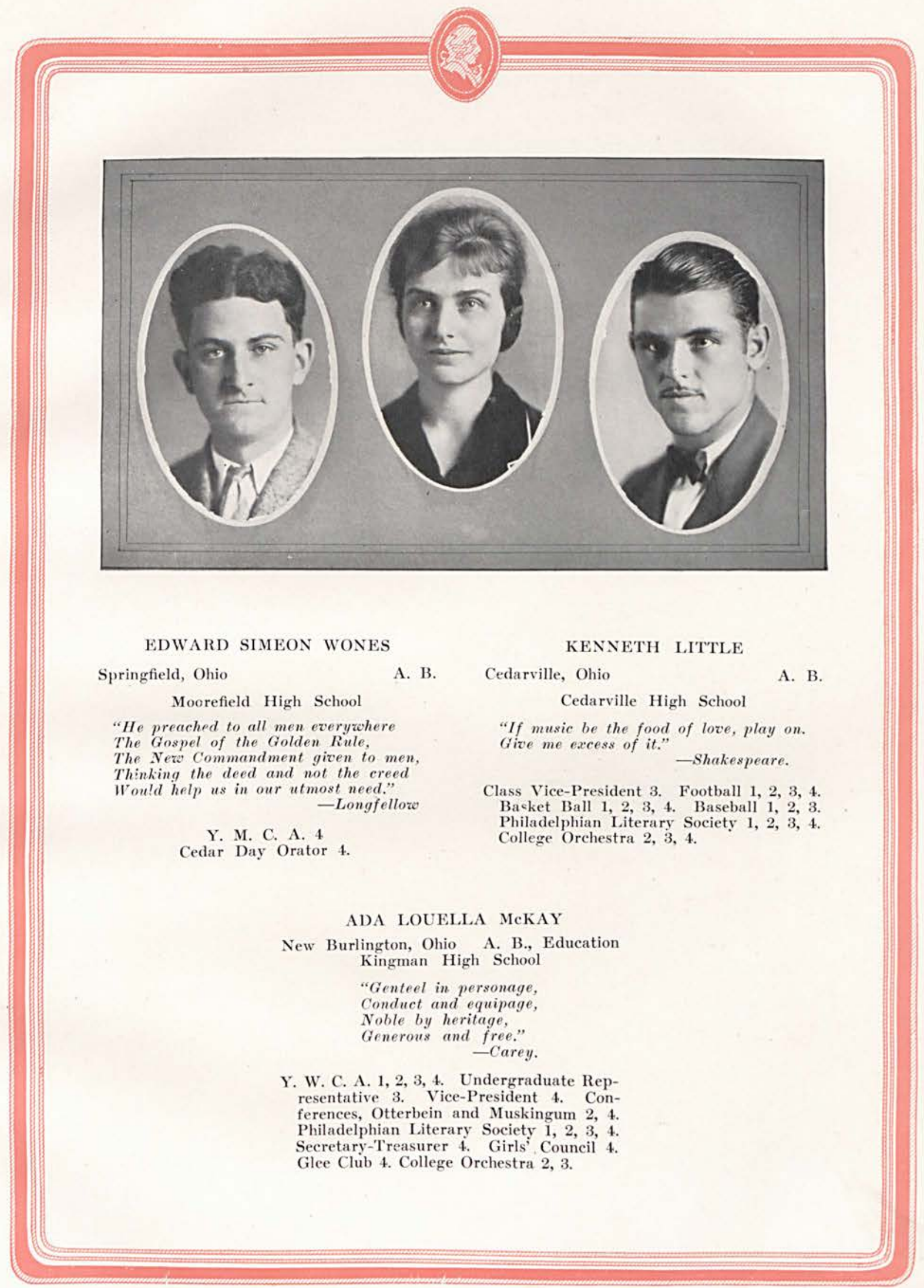

Page Twenty-nine 


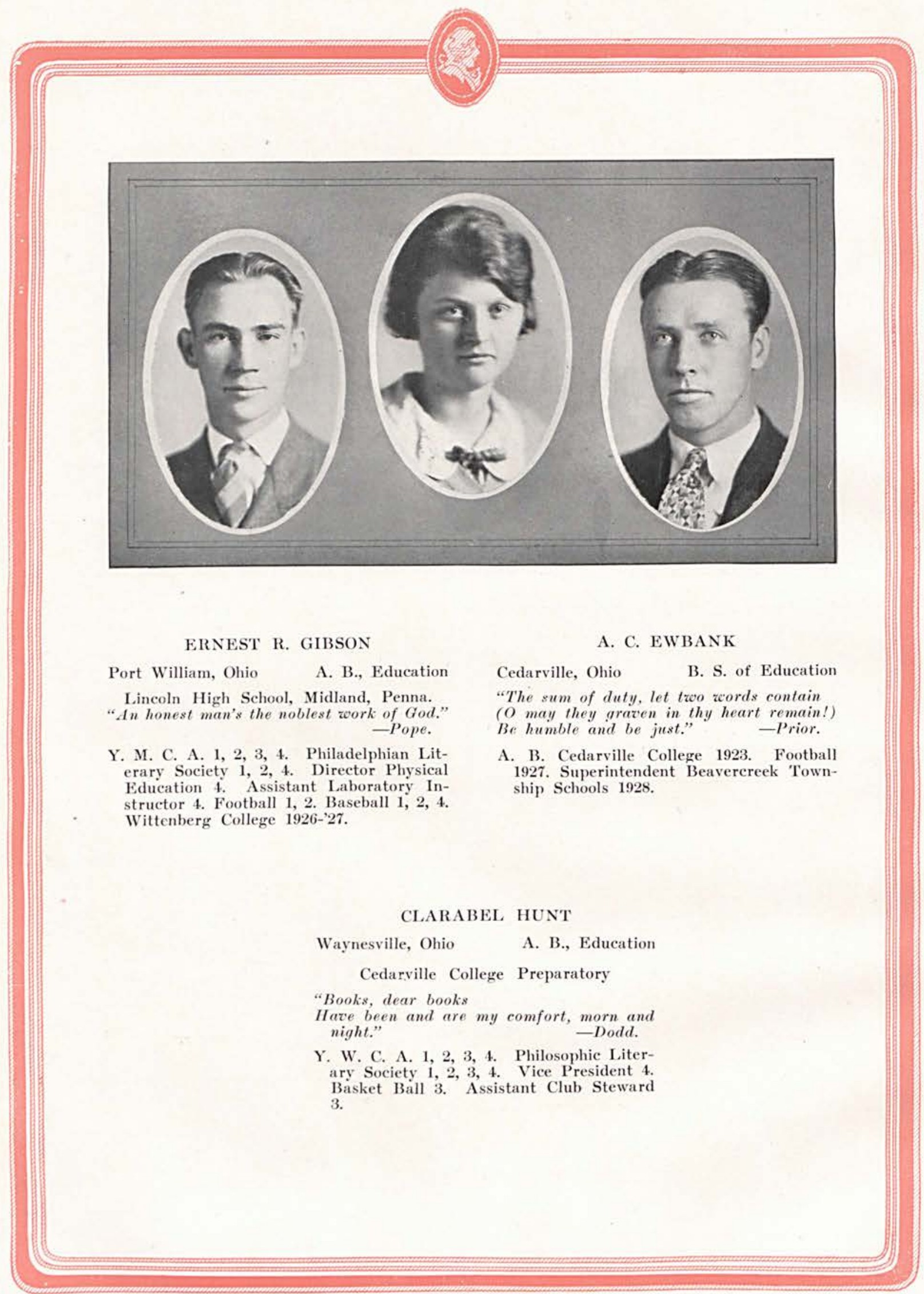

Page Thirty 


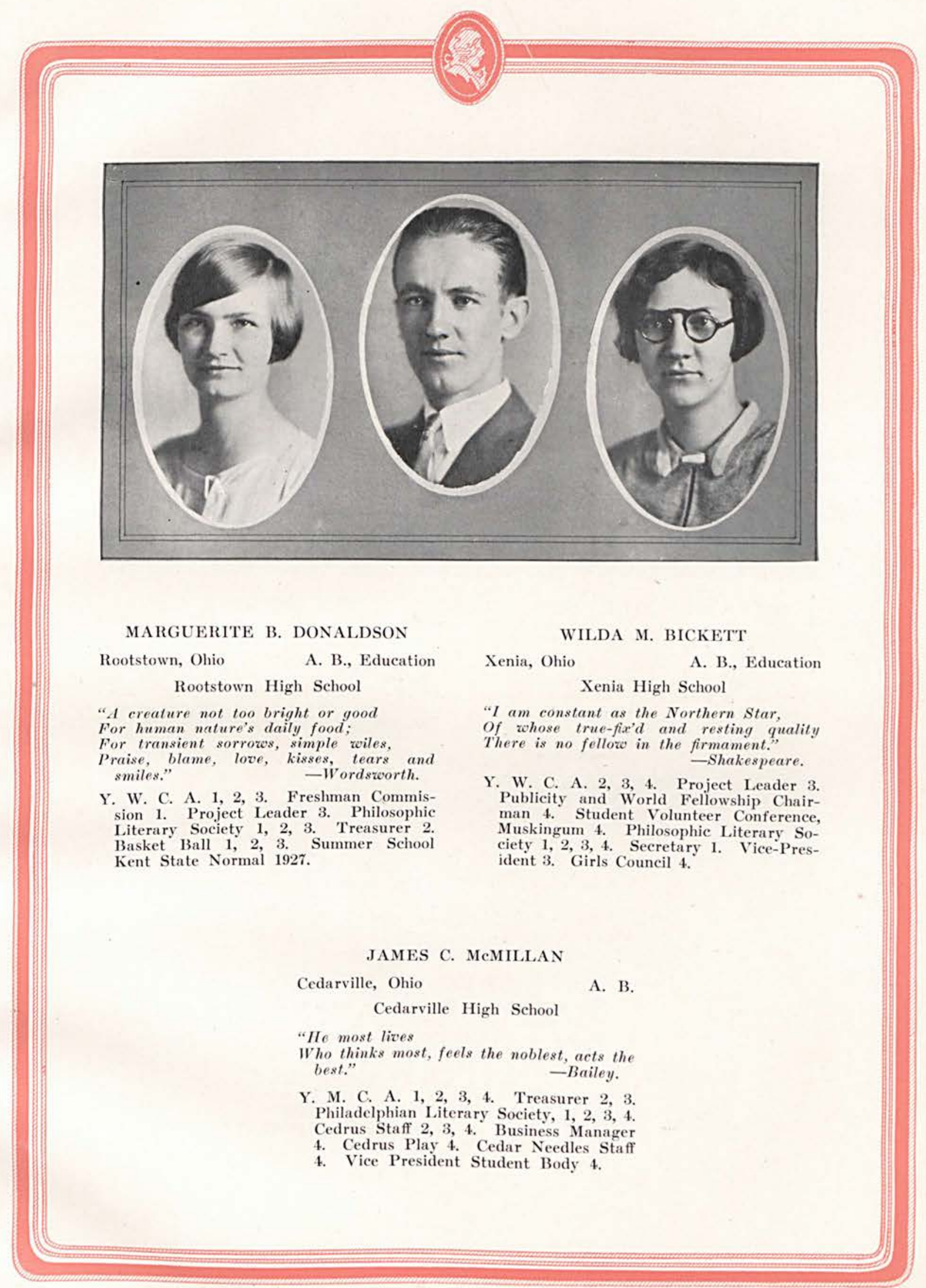

Page Thirty-one 


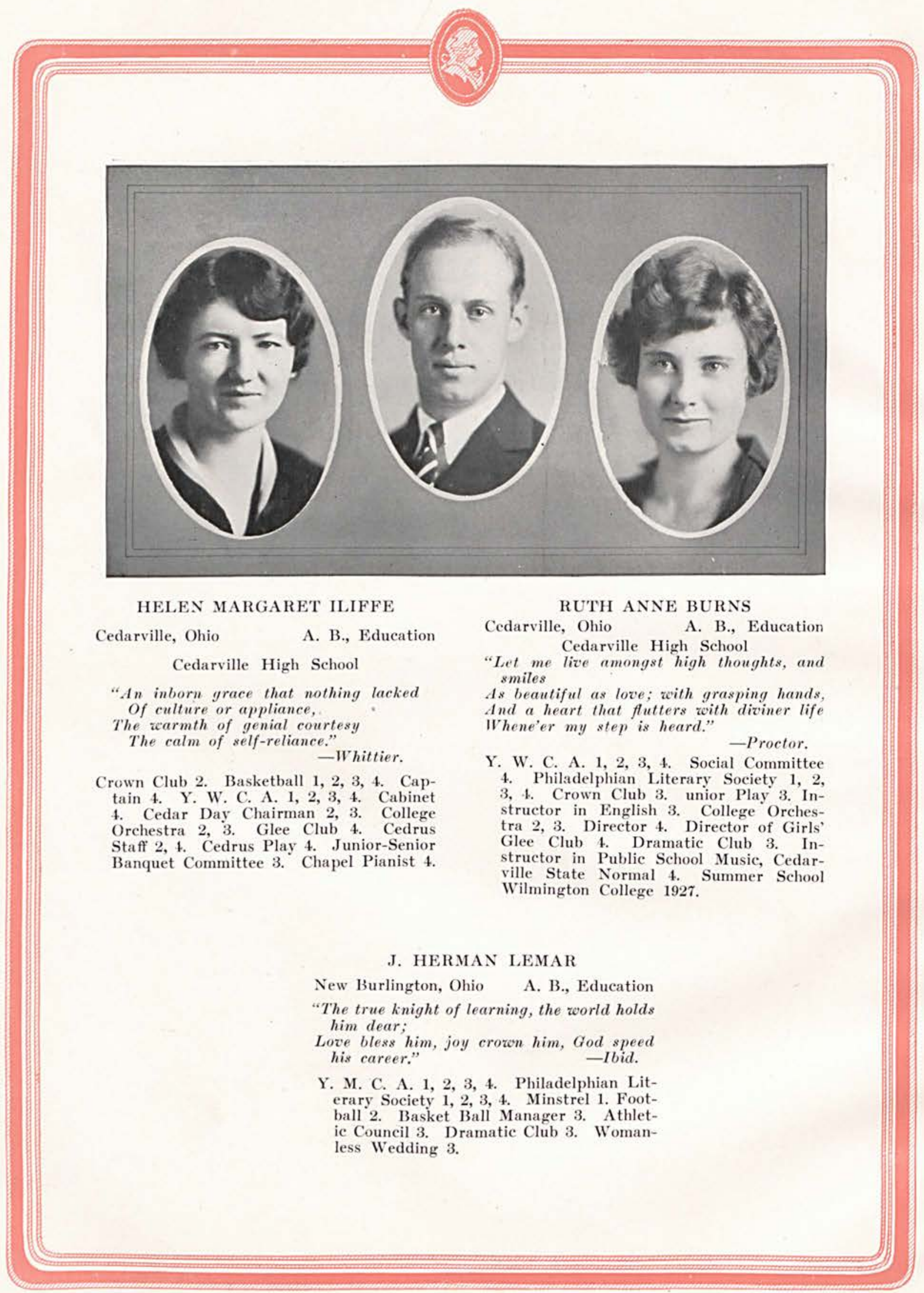

Page Thirty-two 


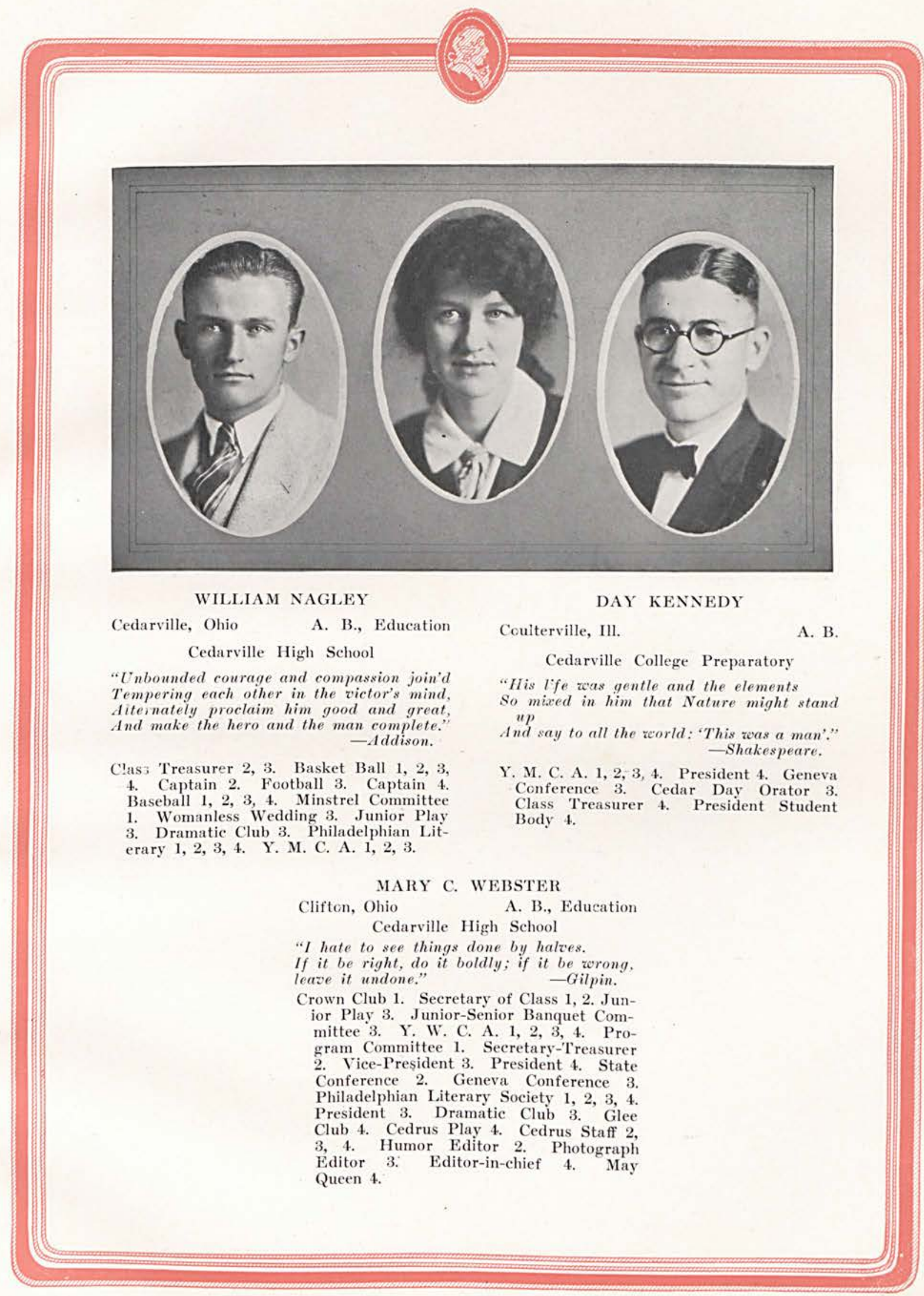

Page Thirty-three 


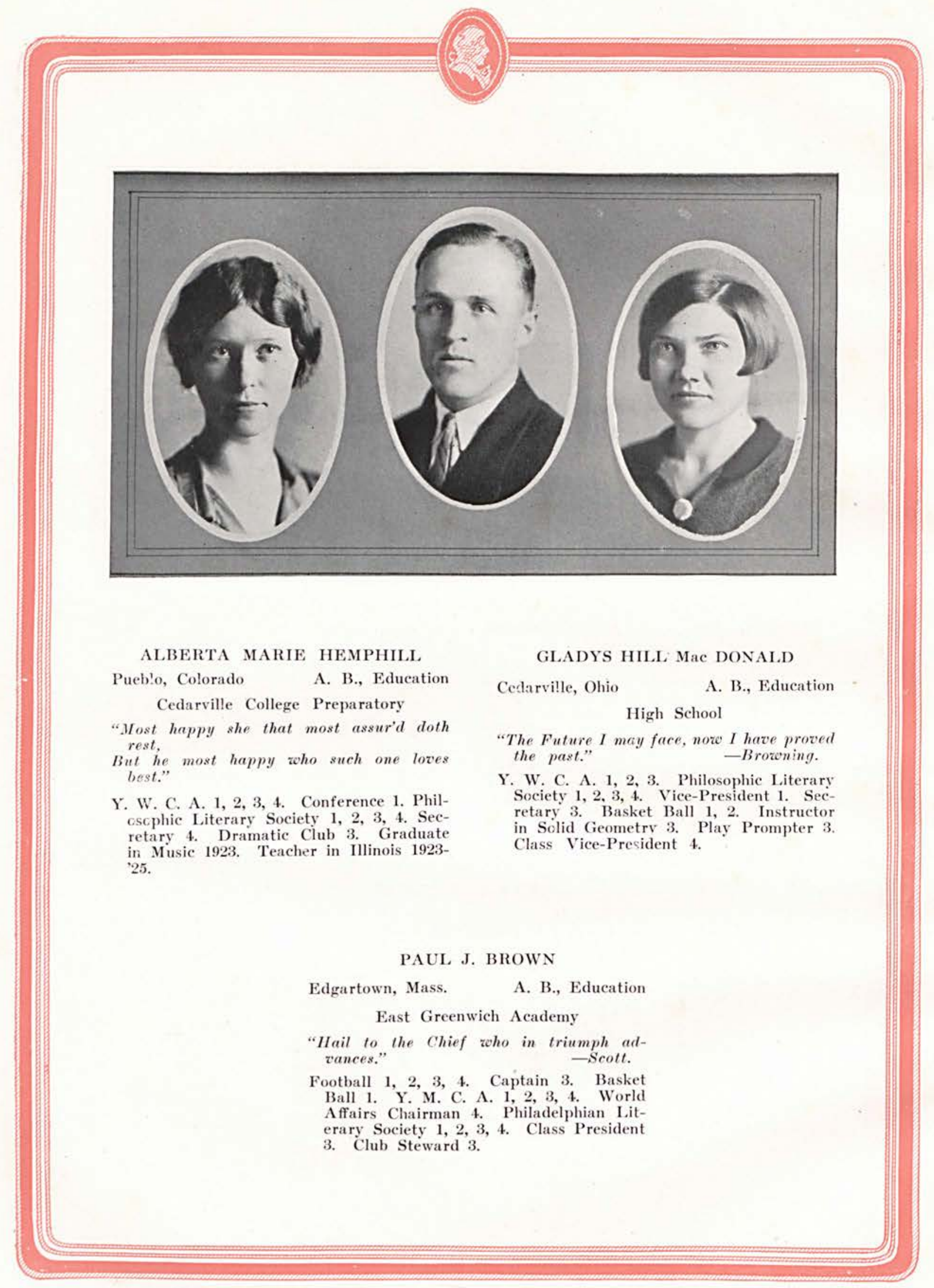

Page Thirty-four 


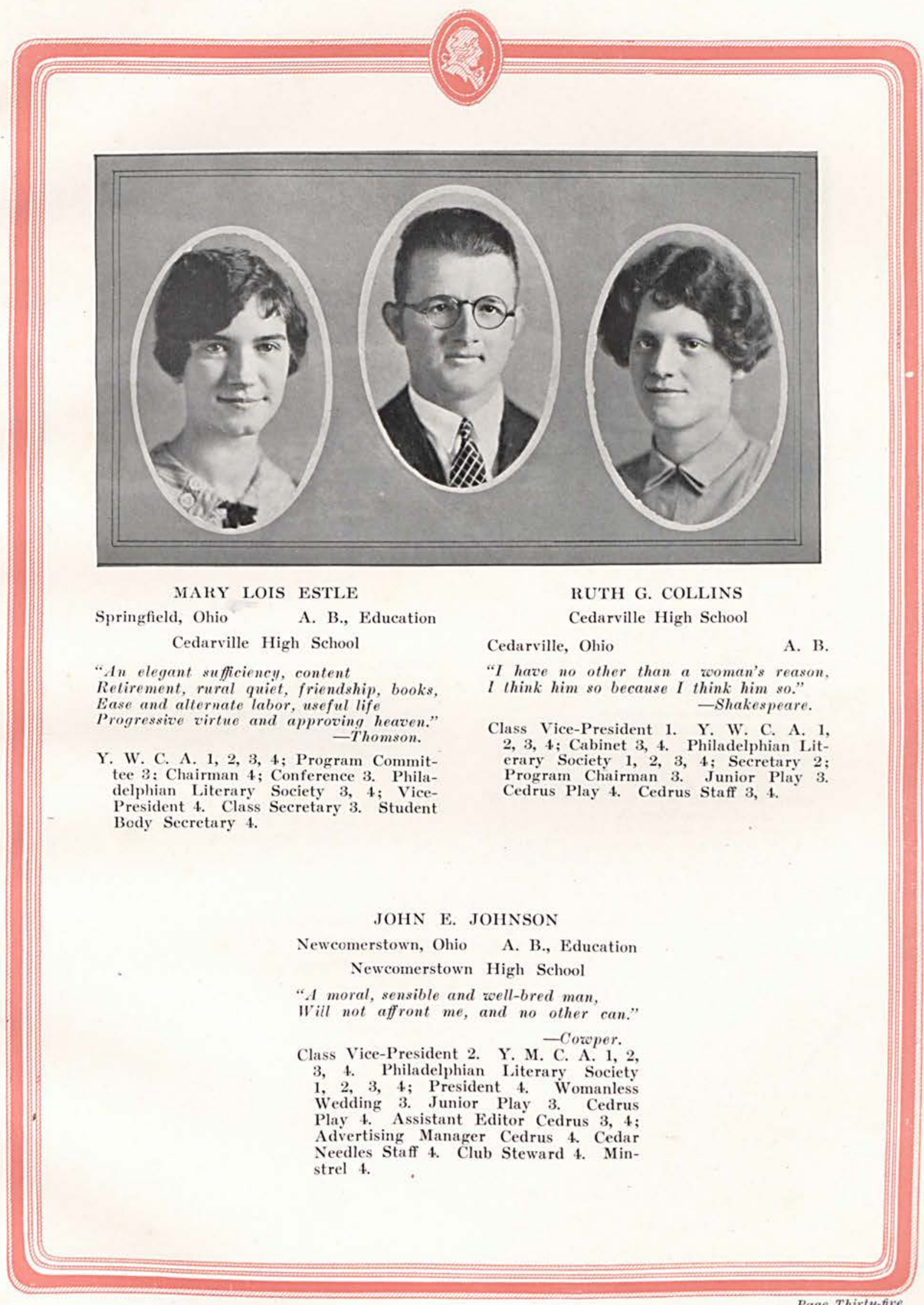

Page Thirty-five 


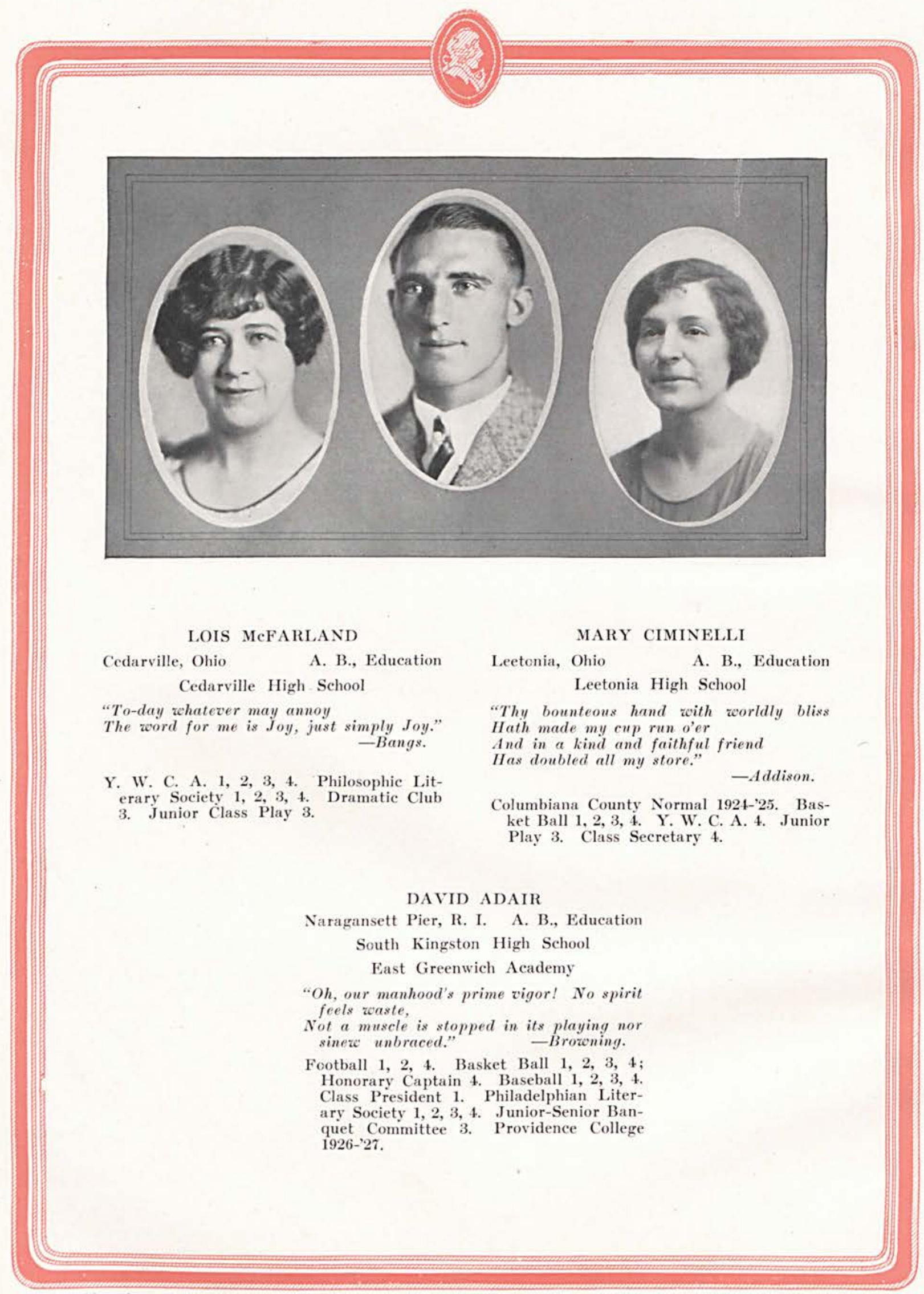

Page Thirty-six 


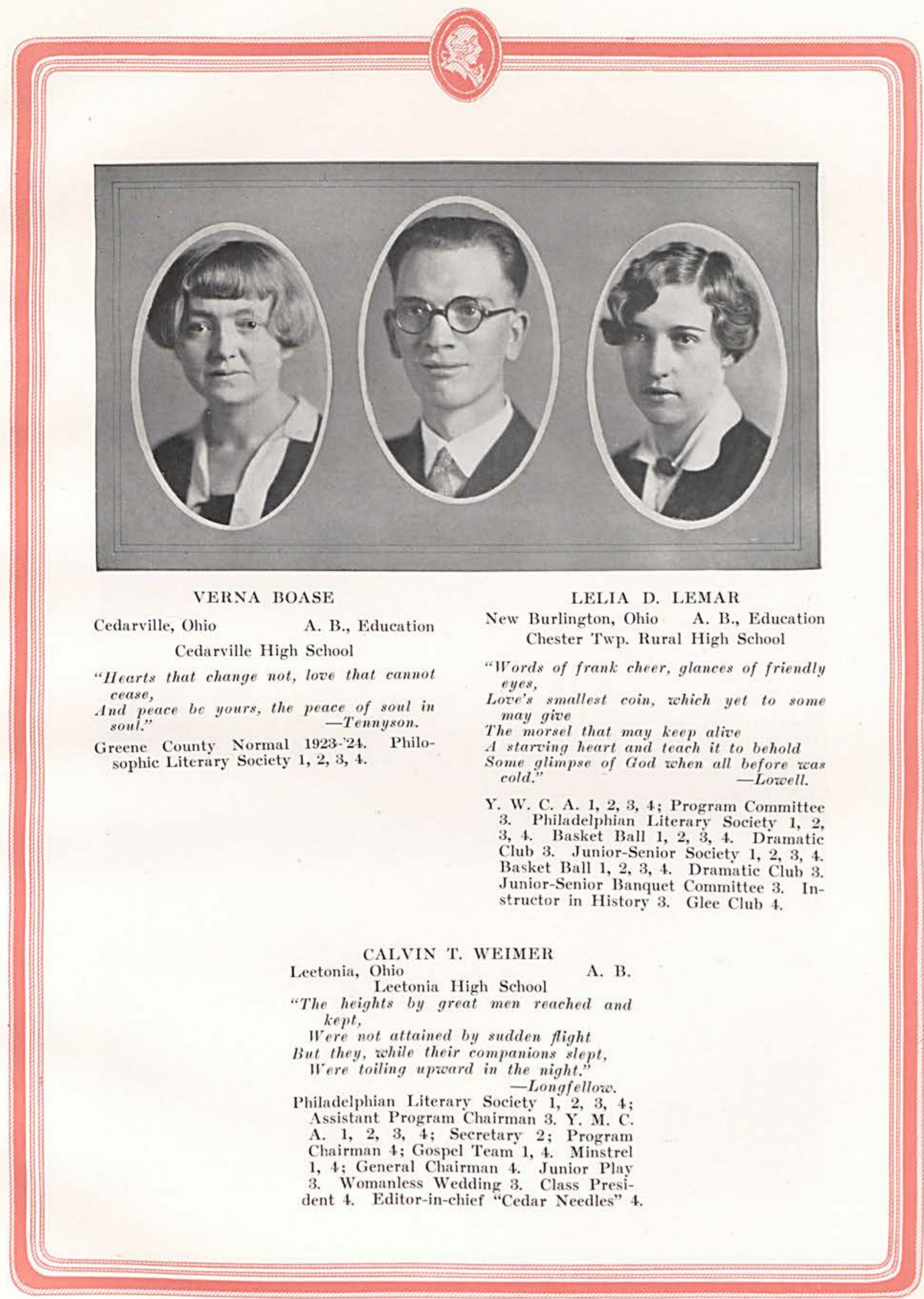

Page Thirty-seven 


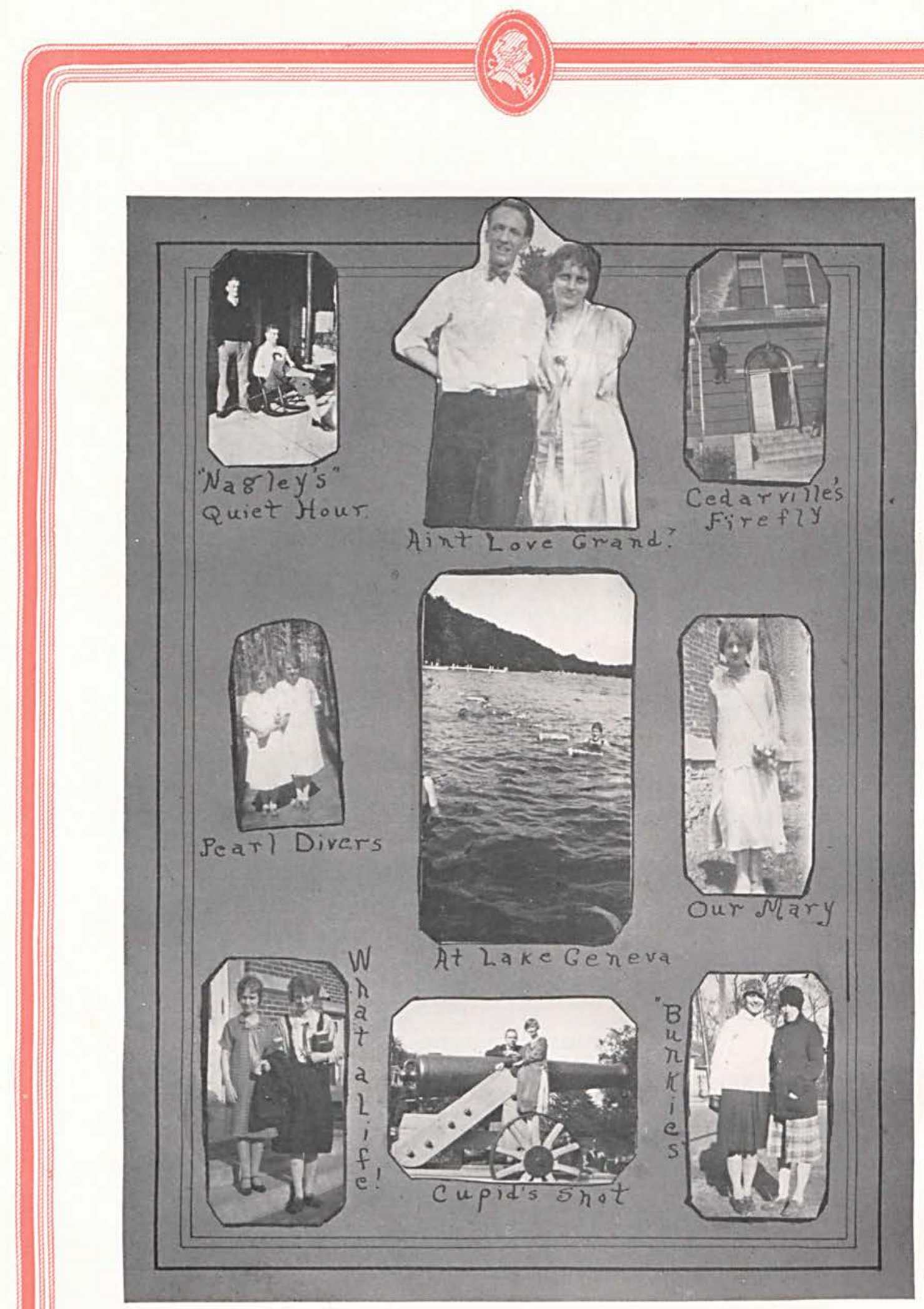

Page Thirty-eight 



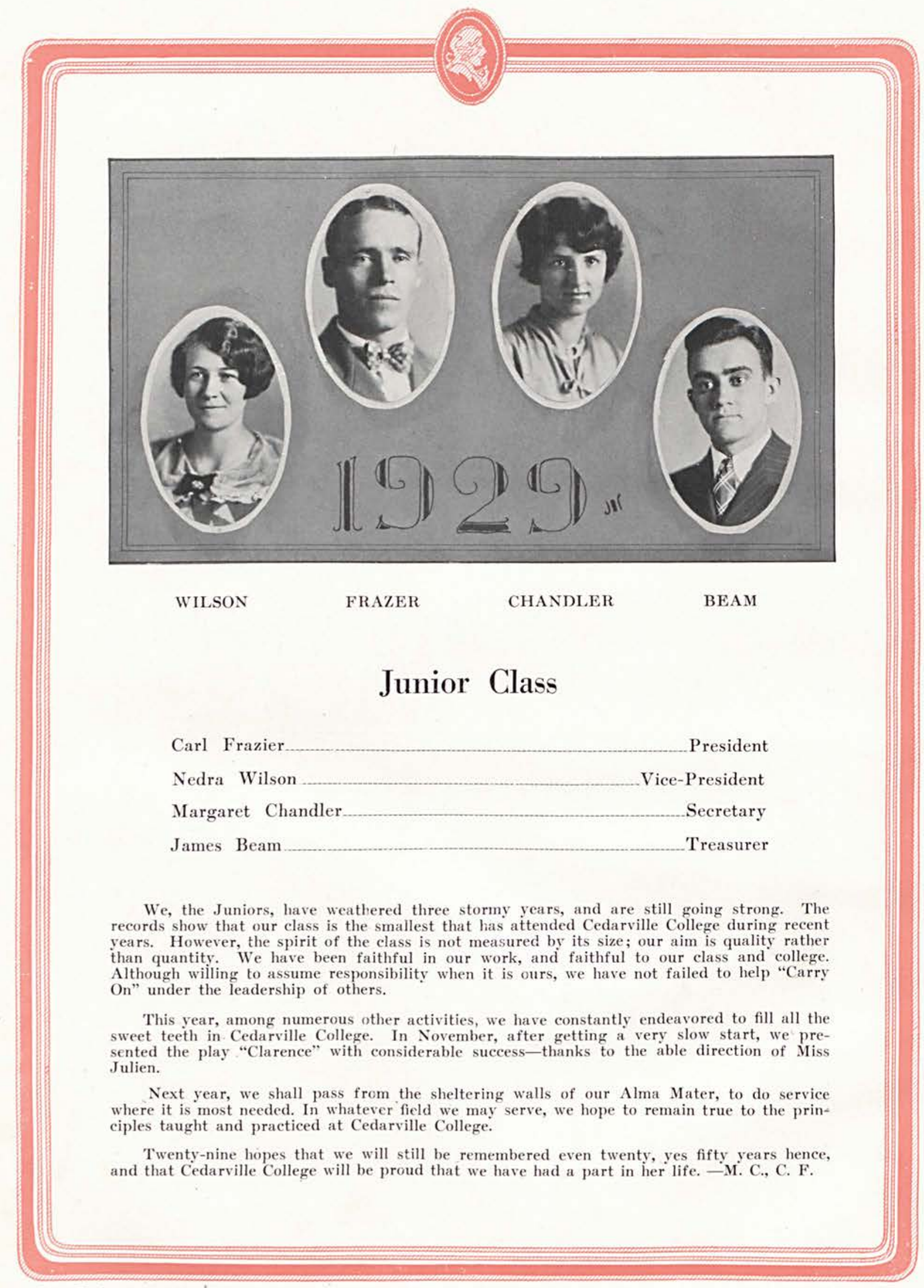

Page Forty 


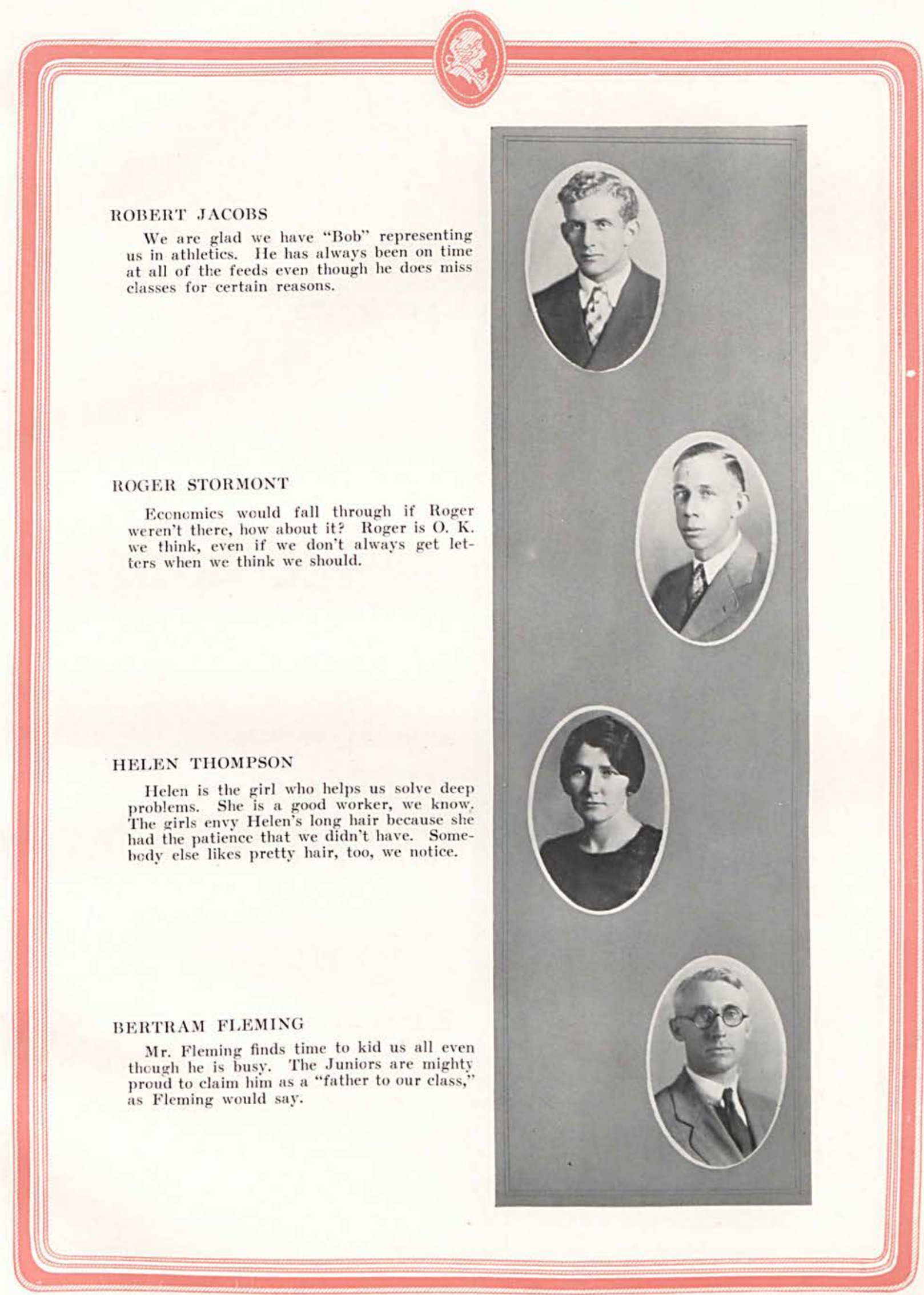

Page Forty-one 


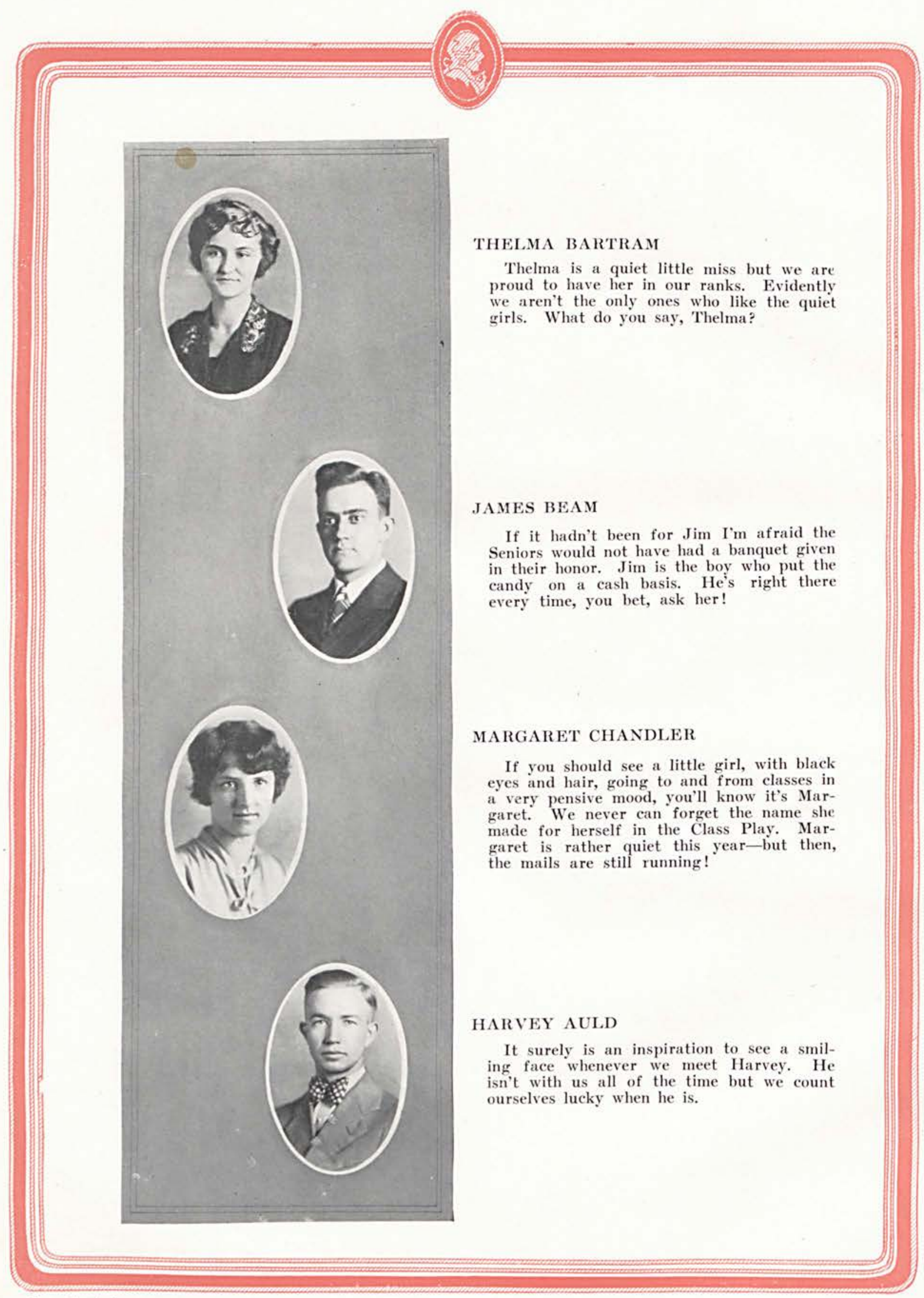

Page Forty-two 


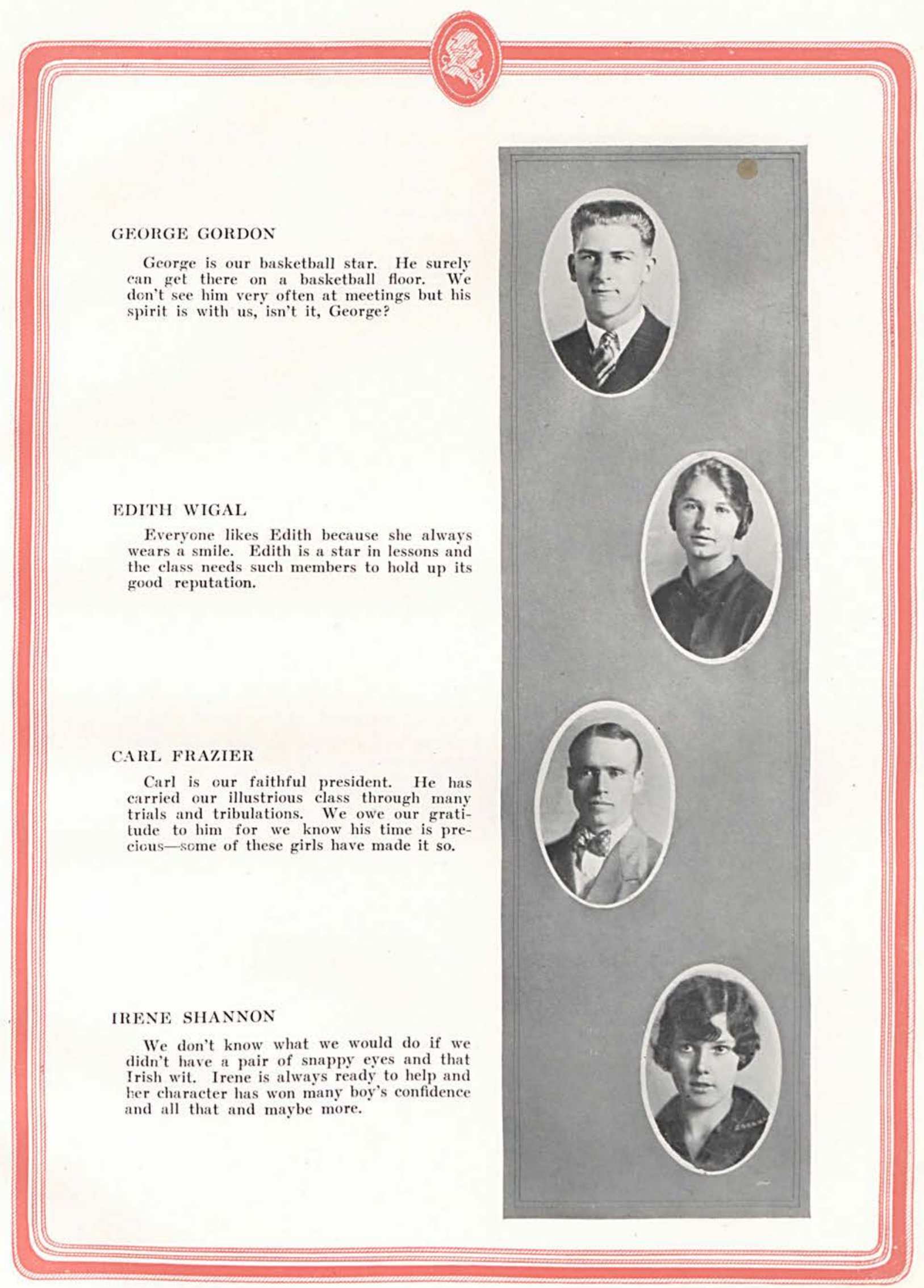

Page Forty-three 


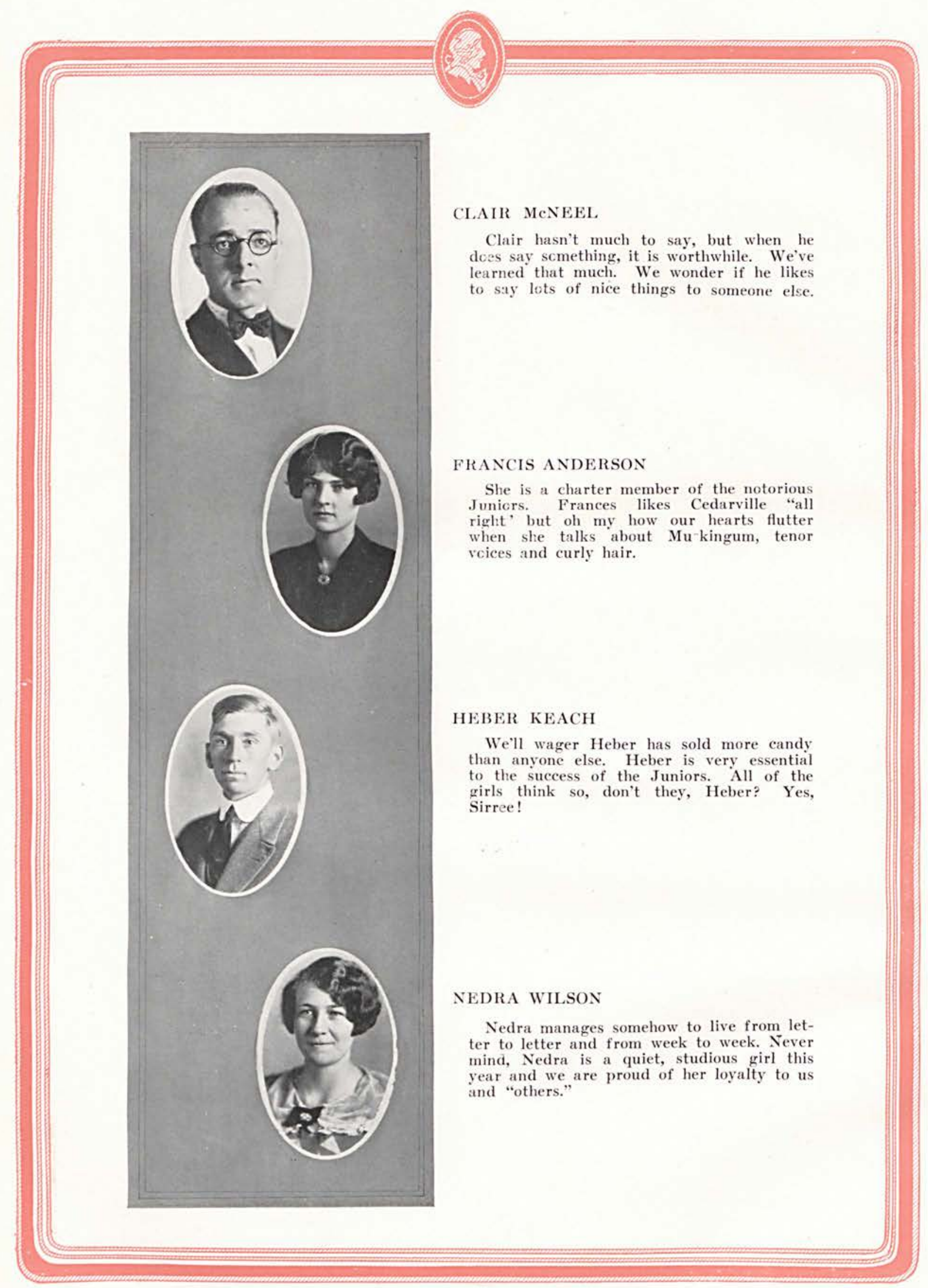

Page Forty-four 


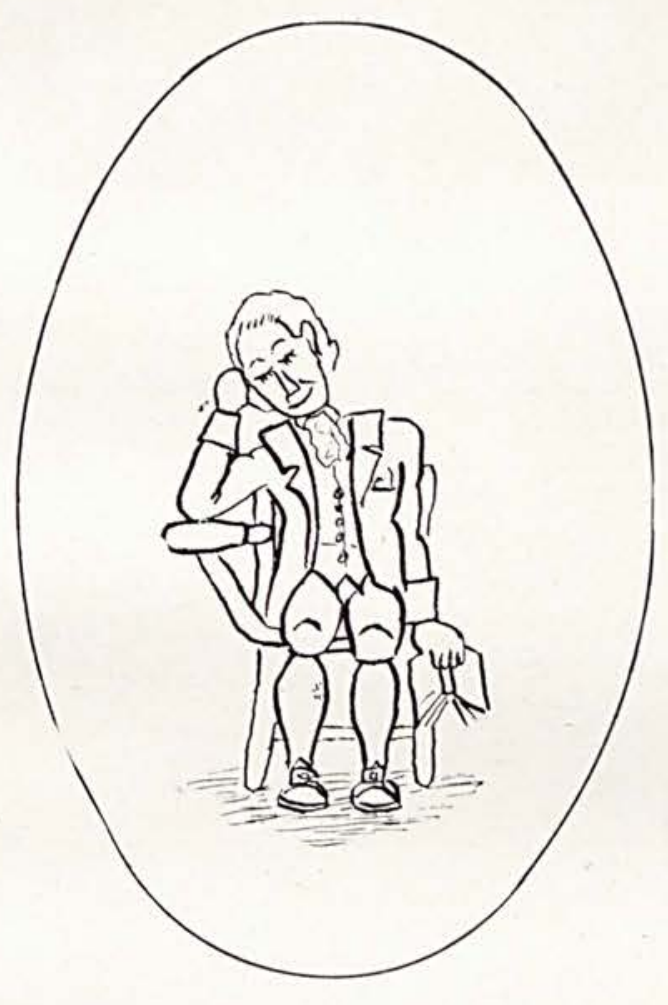

Sophomare 


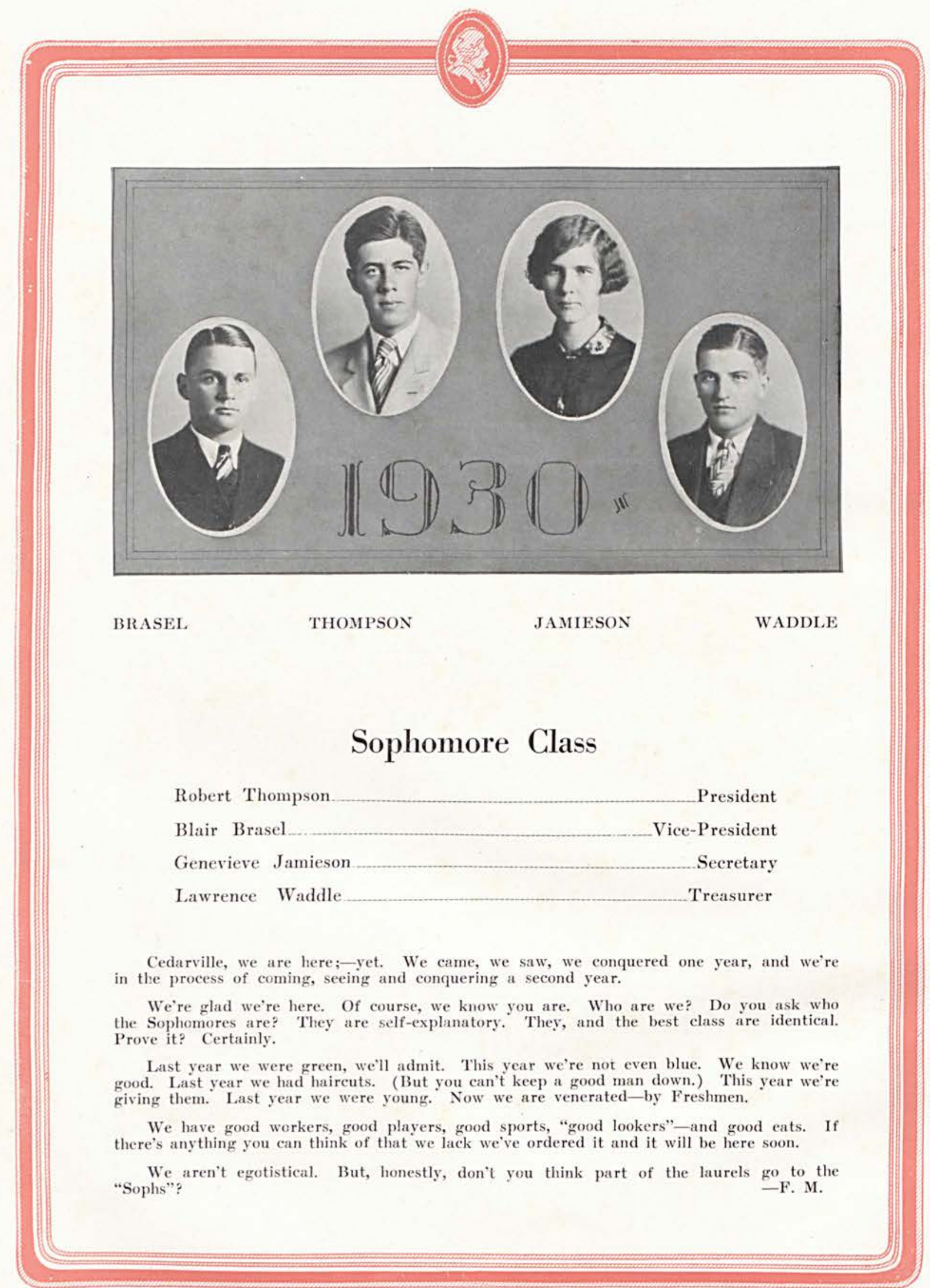

Page Forty-six 


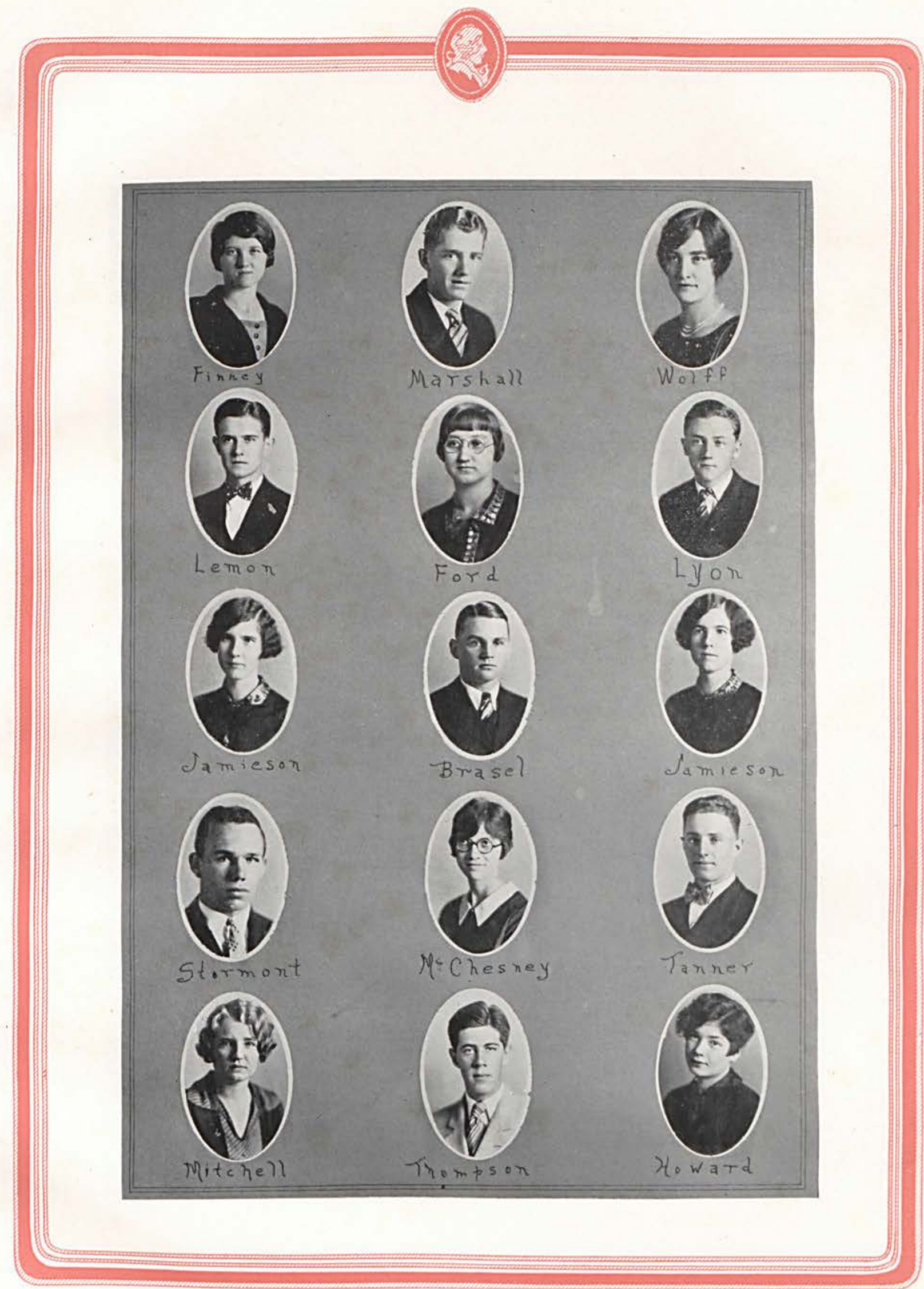

Page Forty-seven 


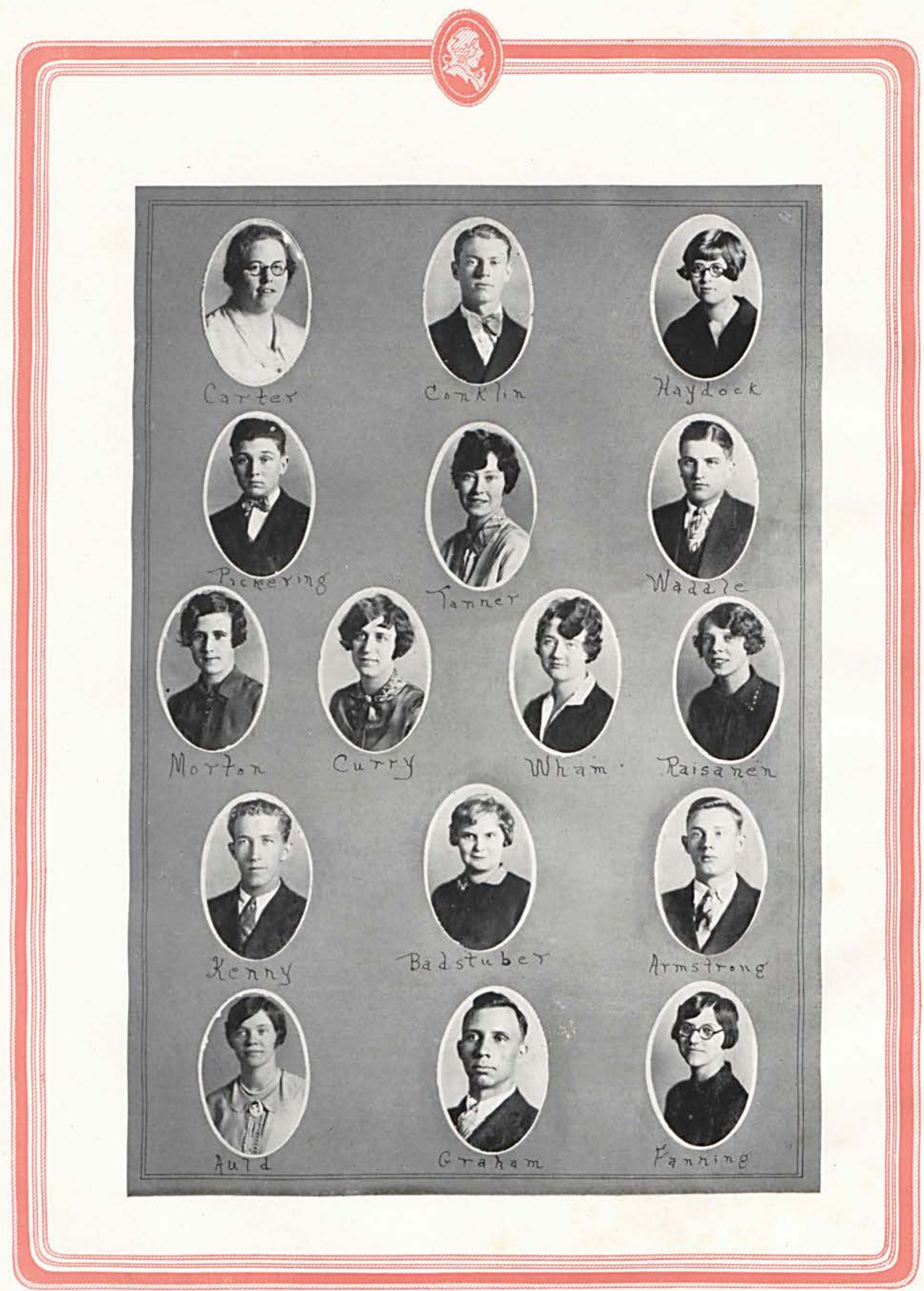

Page Forty-eight 


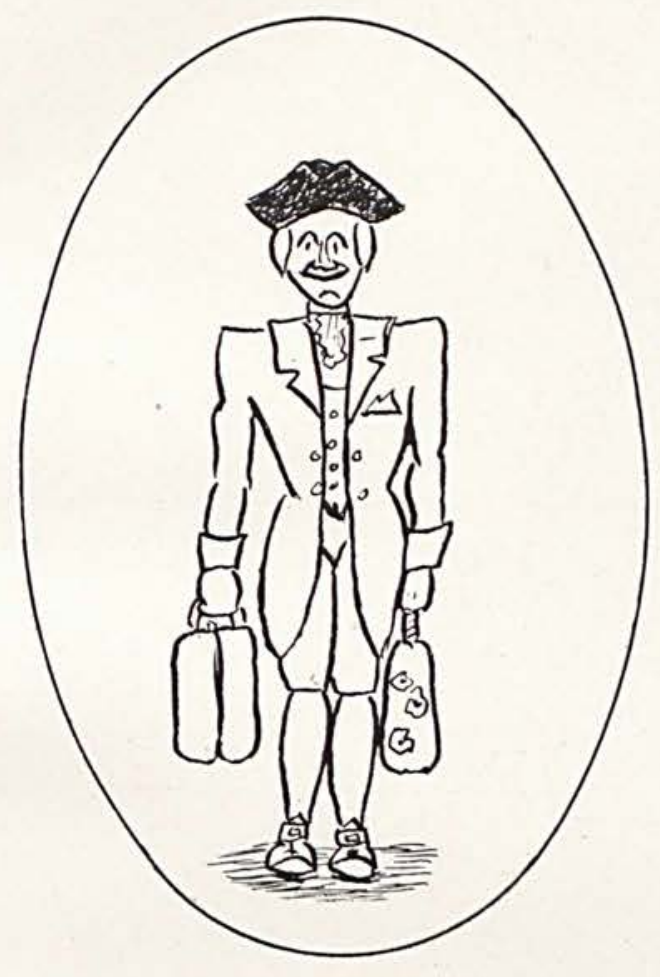

Jirestimen 


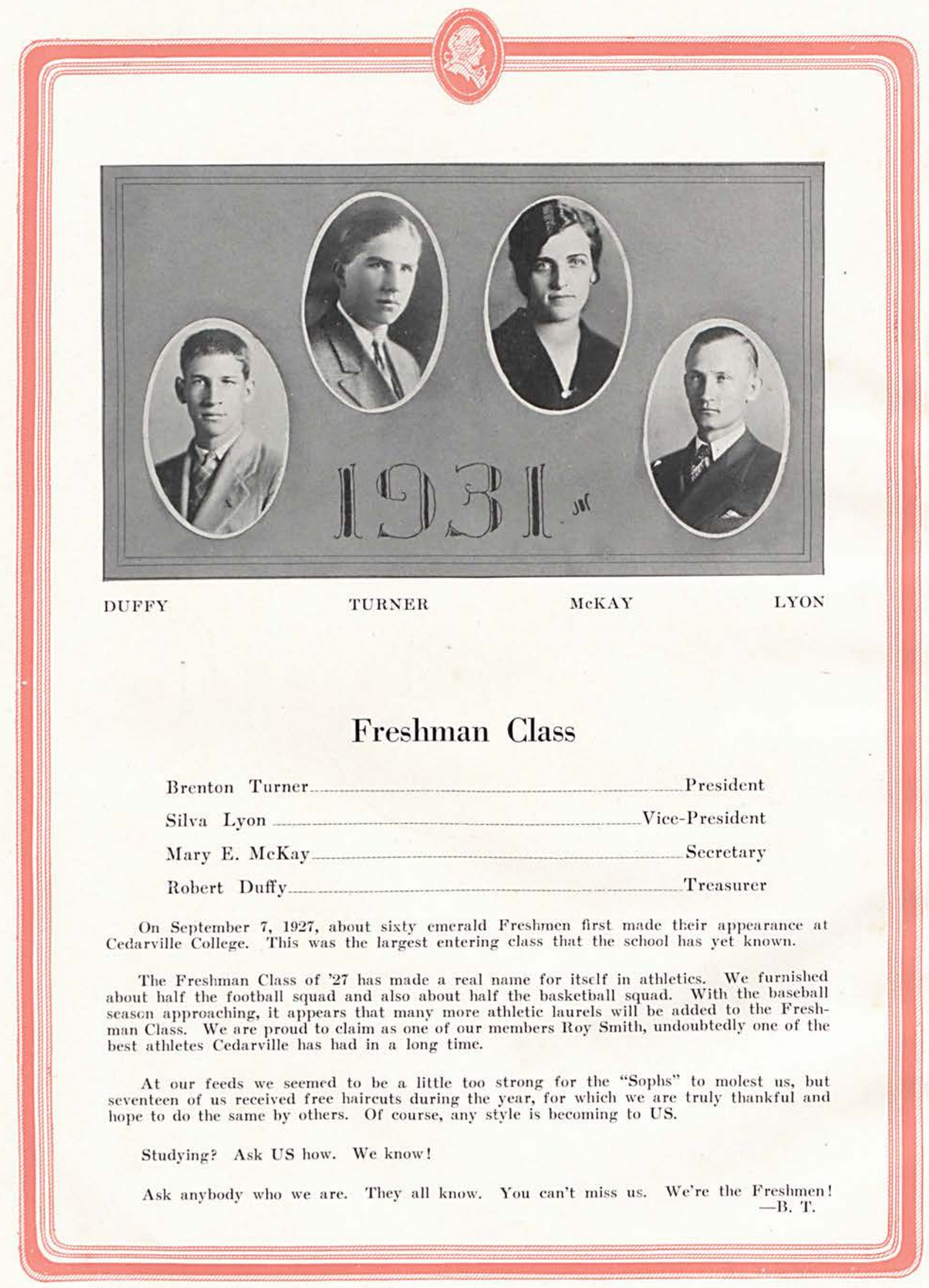

Page Fifty 


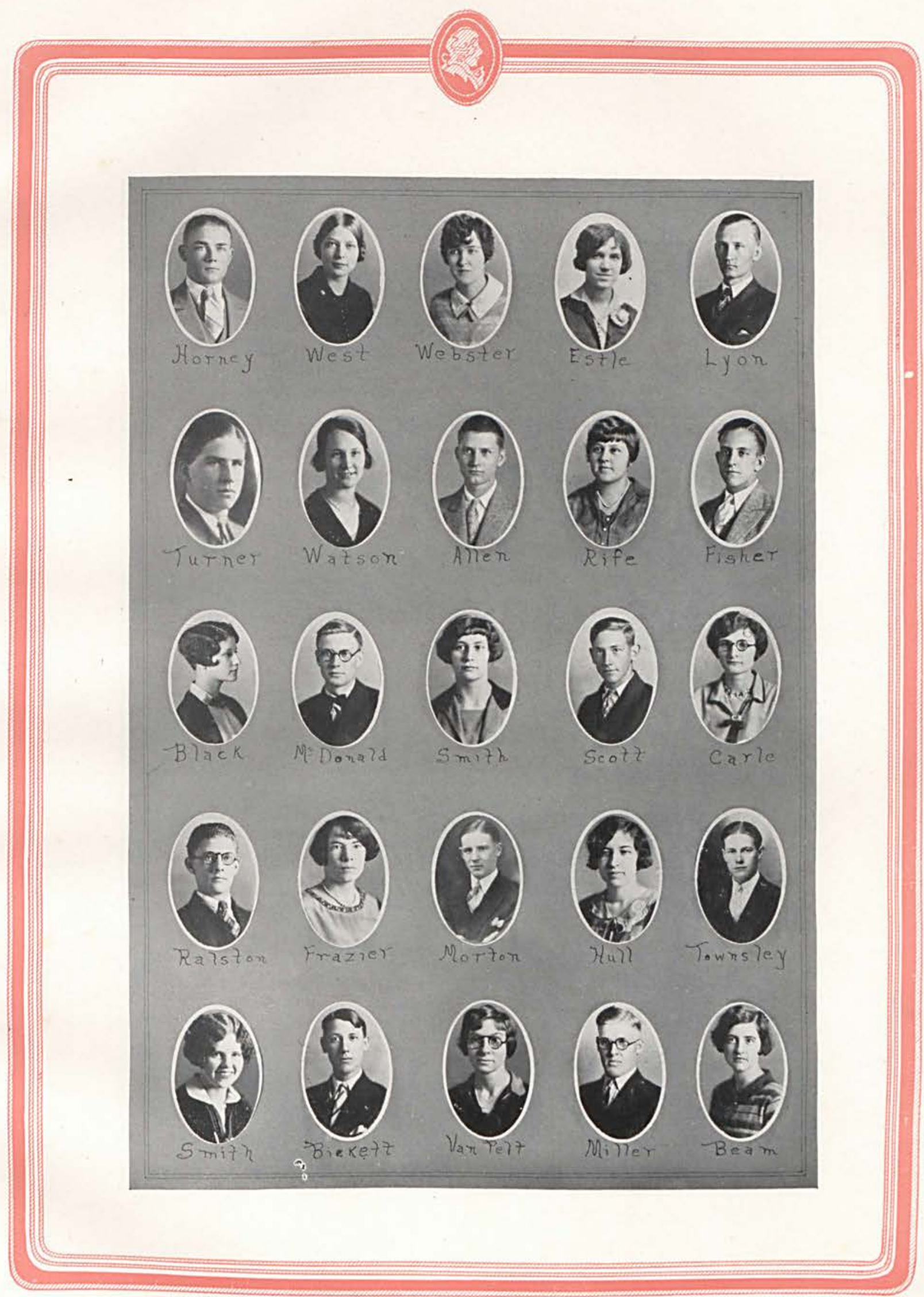




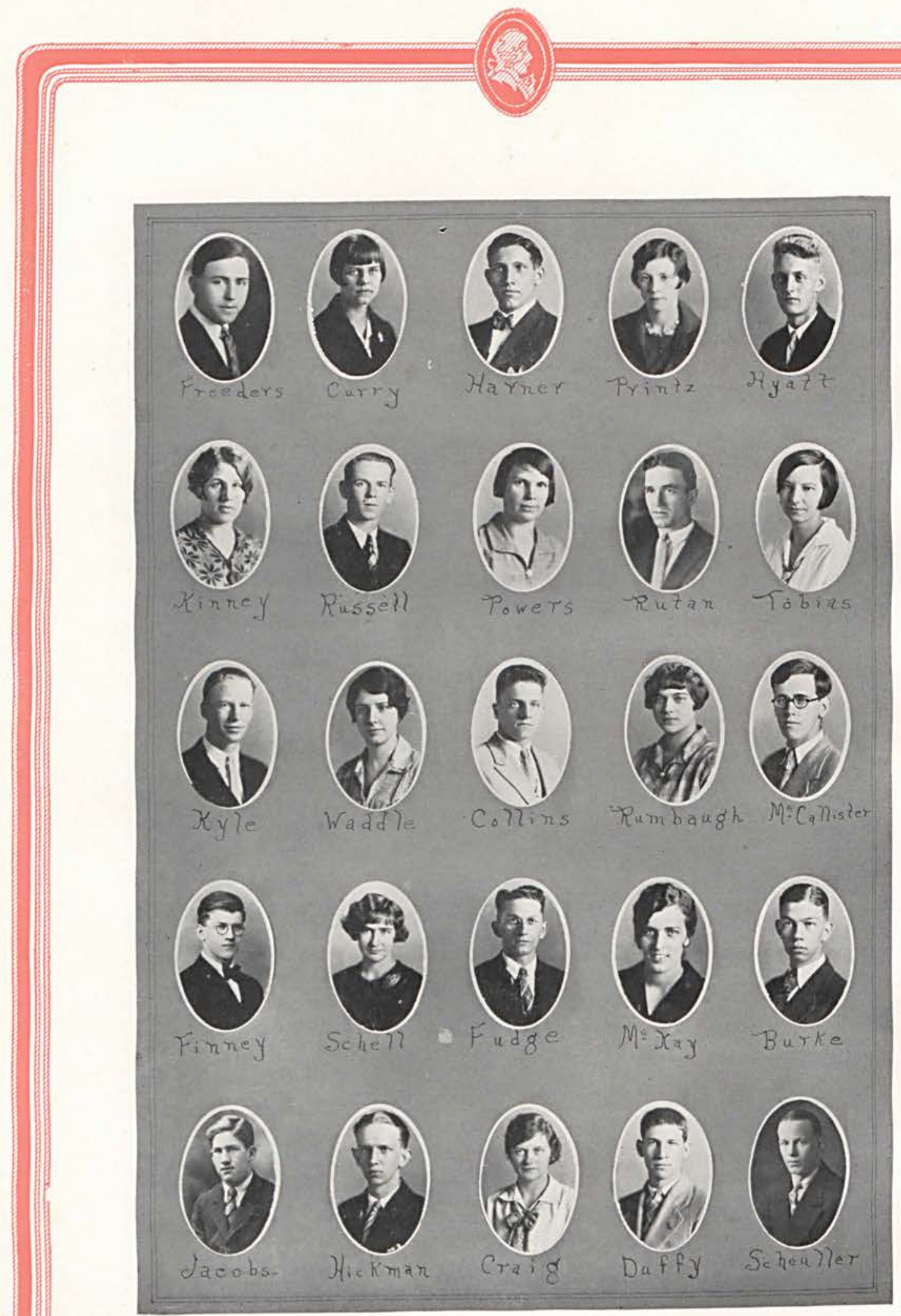

Page Fifty-two 


\section{Cedarville State Normal}

The educational department of Cedarville College has been reorganized with the cooperation of the State Department of Education, and is under its direct supervision. Three courses of instruction prepared by the State Department are offered. These are designed to prepare teachers for lower elementary, upper elementary, and high school instruction.

The outstanding feature is the attempt to present all subject matter from the professional standpoint. This is not a new idea and has proven successful wherever attempted. Much needs to be done to improve and extend this type of instruction for training teachers for better service.

Observation and student teaching are necessary to fix desirable professional ideals and habits. This is done in the public schools of Cedarville. The fine spirit of cooperation, and convenient location near the College make an ideal situation for the work.

The success of this first year's work is quite satisfactory to all concerned. However, any new enterprise is apt to grow gradually in size and efficiency, and it is the hope of those immediately concerned, that this venture may grow to larger proportions as the years pass. With the decrease of the county normals, a greater number will be seeking admission at other institutions; and with more rigid requirements preliminary to entering upon the work of teaching, a longer period in training will be necessary. These conditions will no doubt insure growth for this department.

Initial steps have already been taken to extend the two-year normal course to a four-year course leading to the degree of Bachelor of Science in Education. Opportunities equal to the best are thus afforded for any who may desire such advantages.

A group large enough to make the work interesting is desirable. But our aim is for efficient work rather than for large numbers; to aid ambitious young people with ability, at small cost; and to set high ideals for those who seek our aid, that they may so equip themselves as to become masters within their spheres of influence.

A. J. H. 


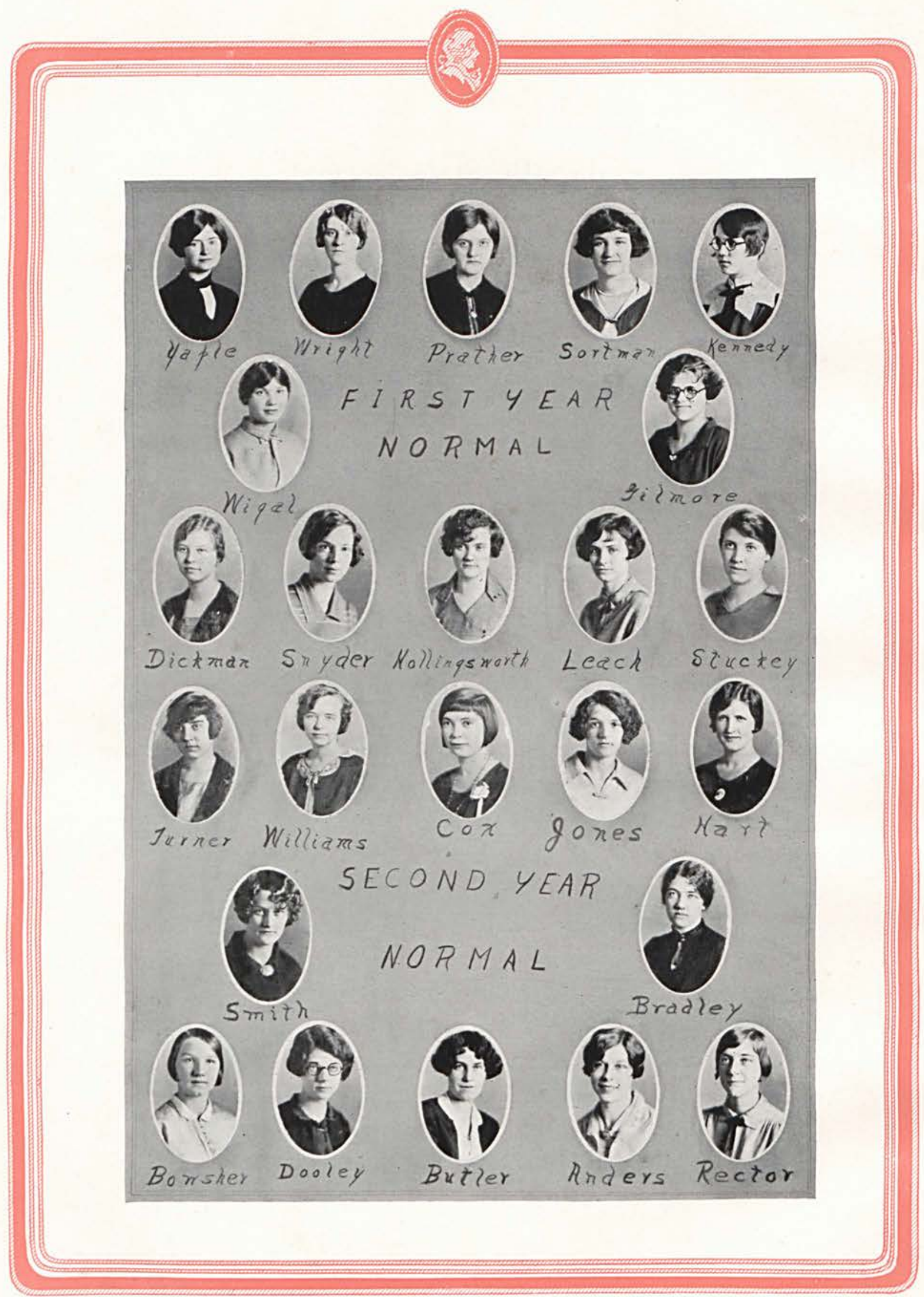

Page Fifty-four 


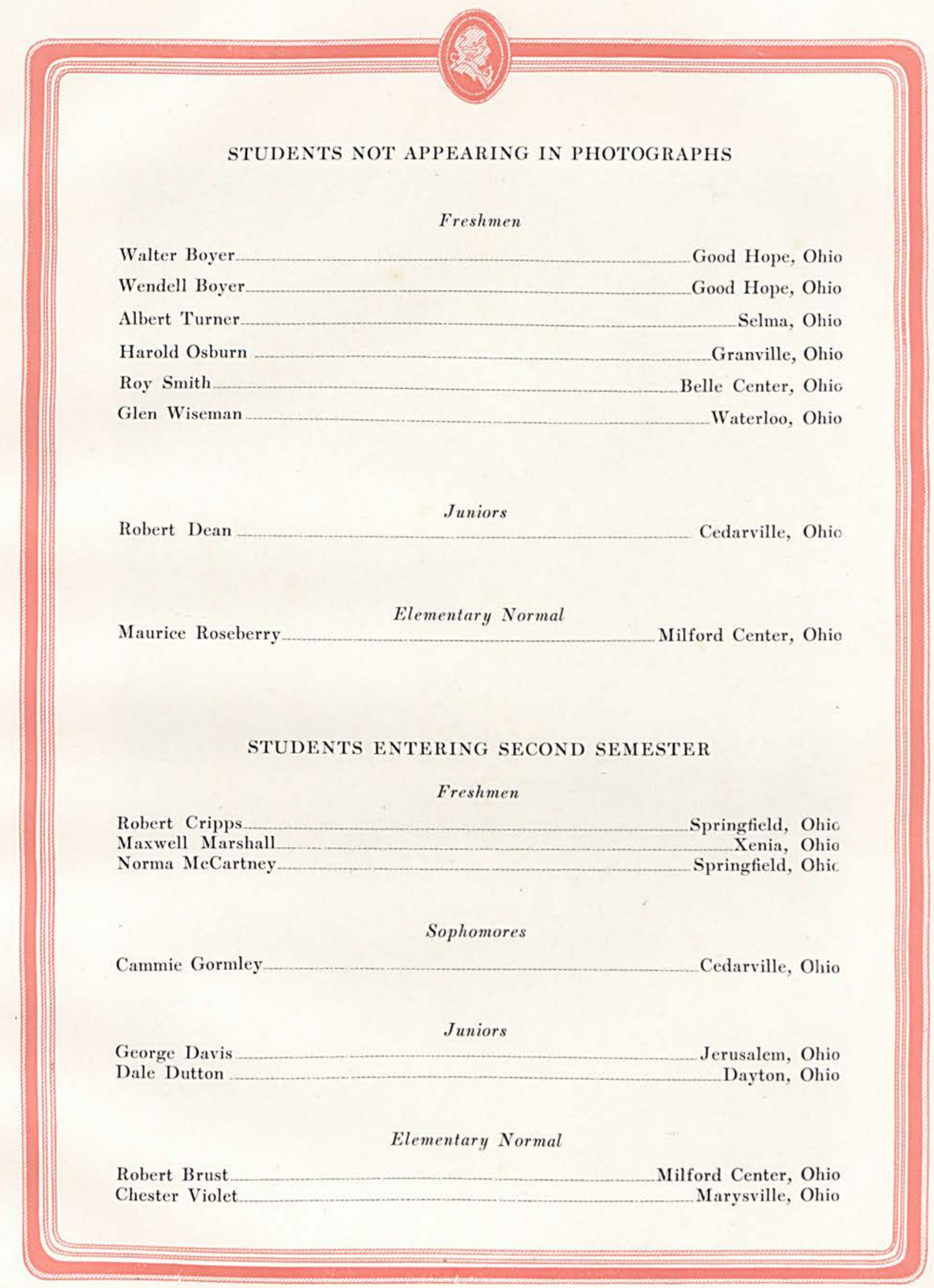

Page Fifty-five 


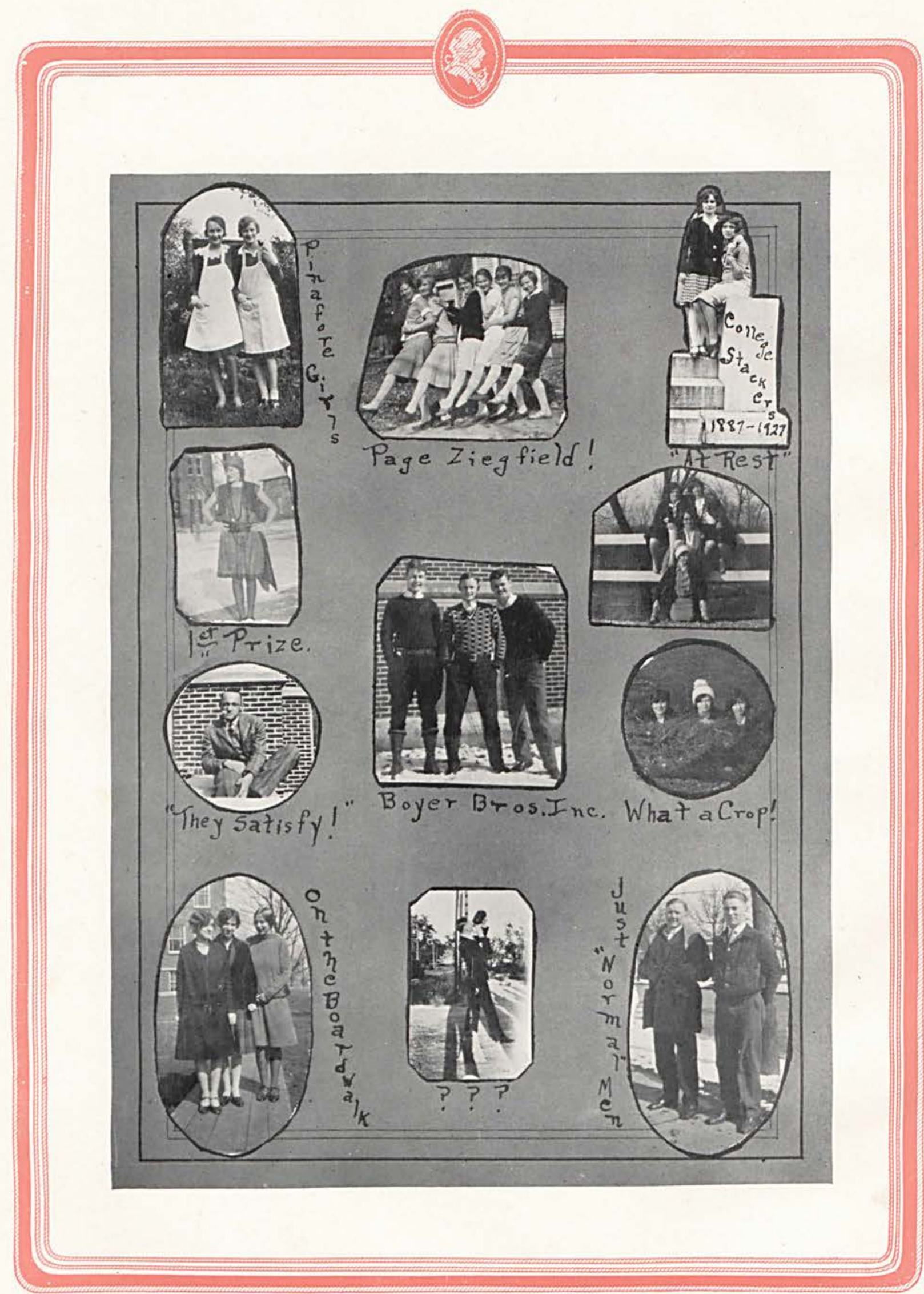

Page Fifty-six 


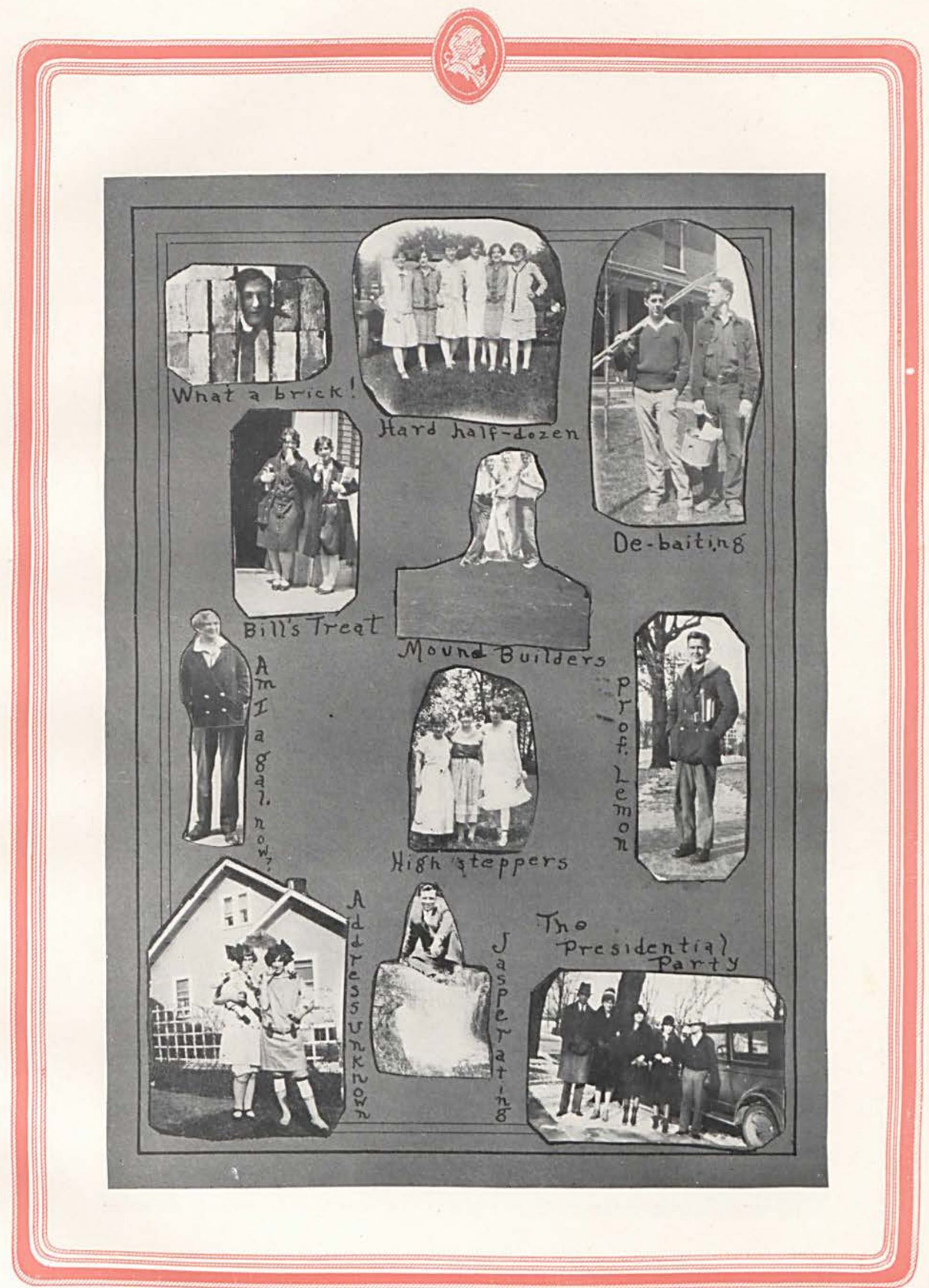

Page Fifty-seven 


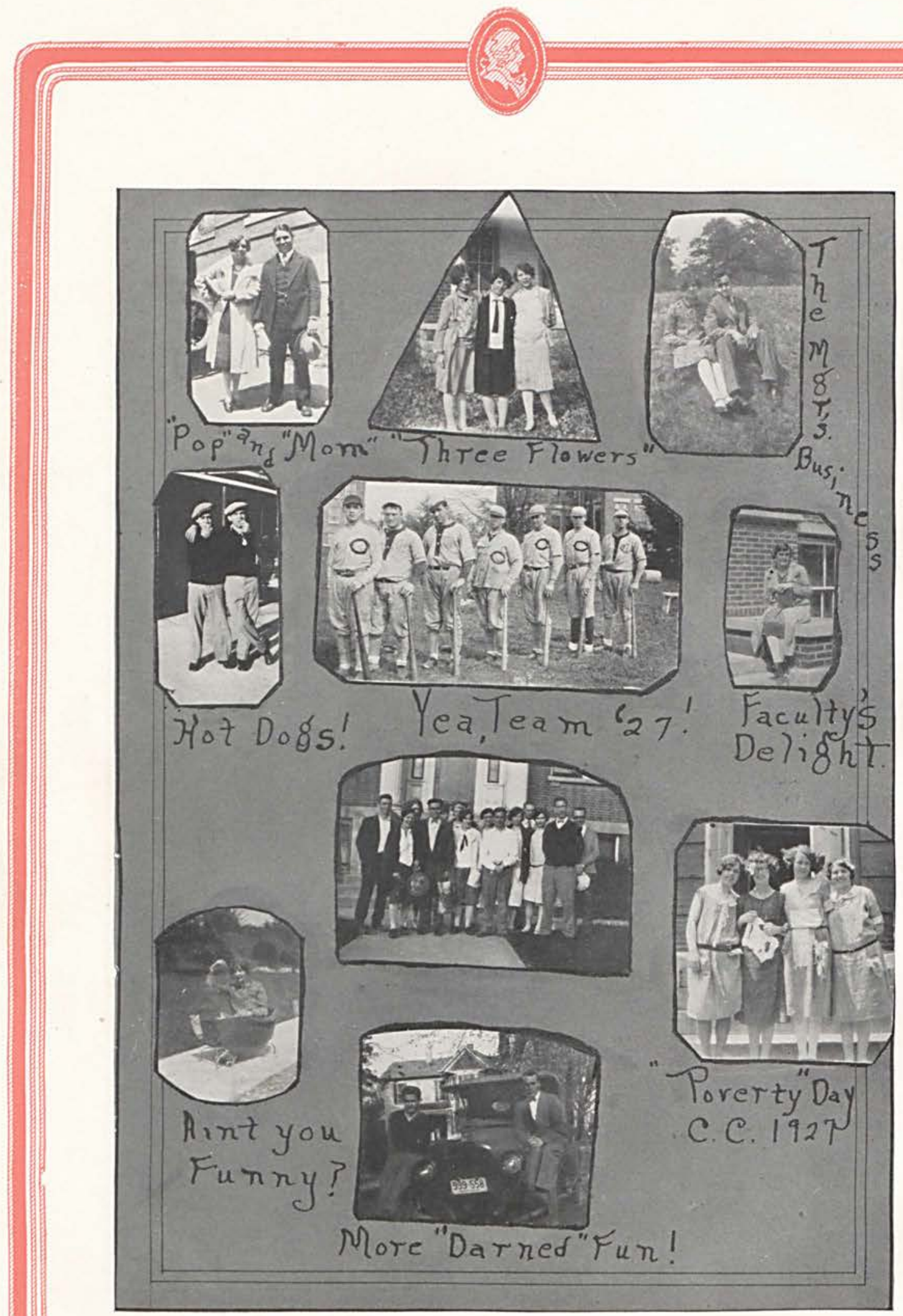

Page Fifty-eight 


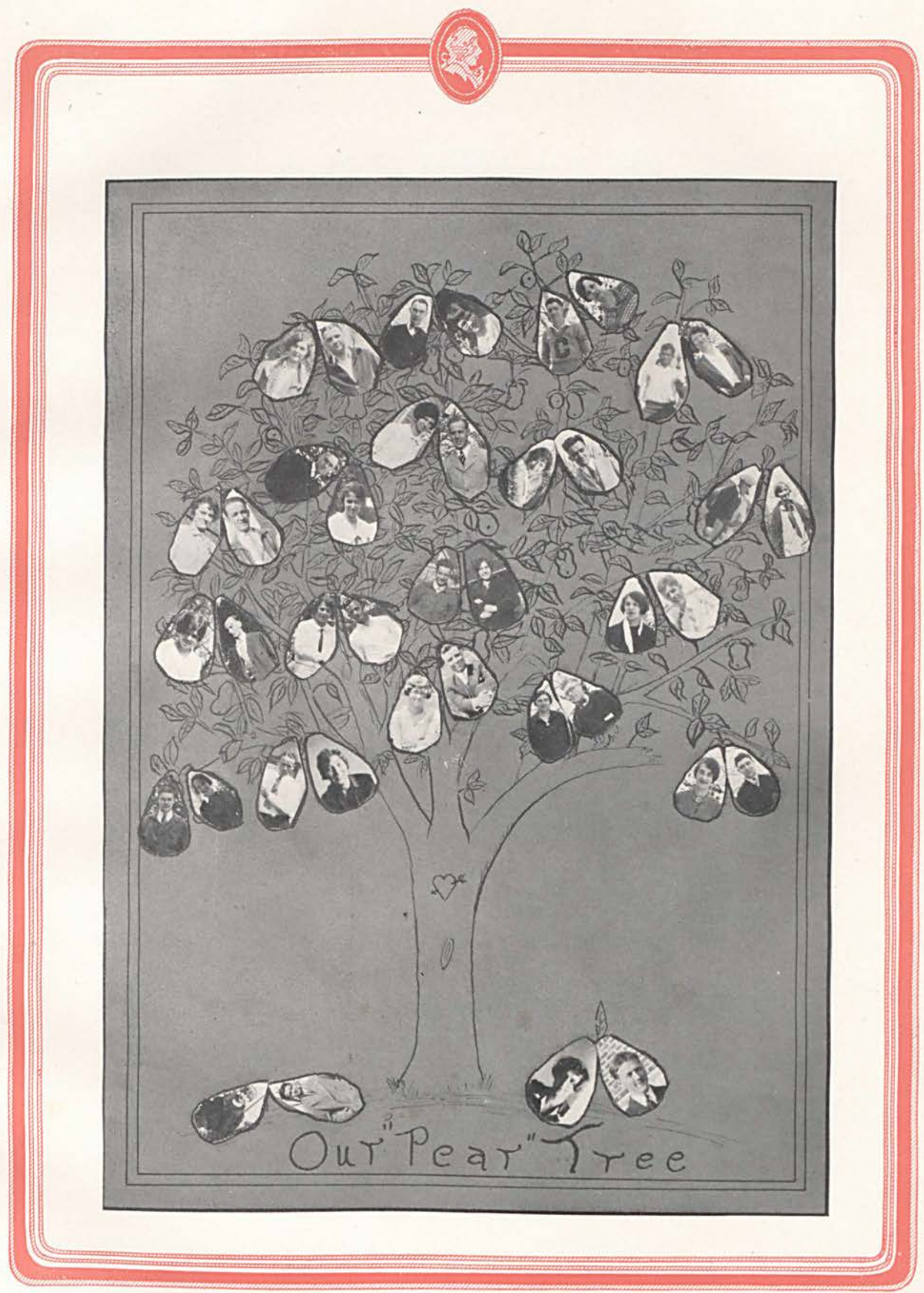




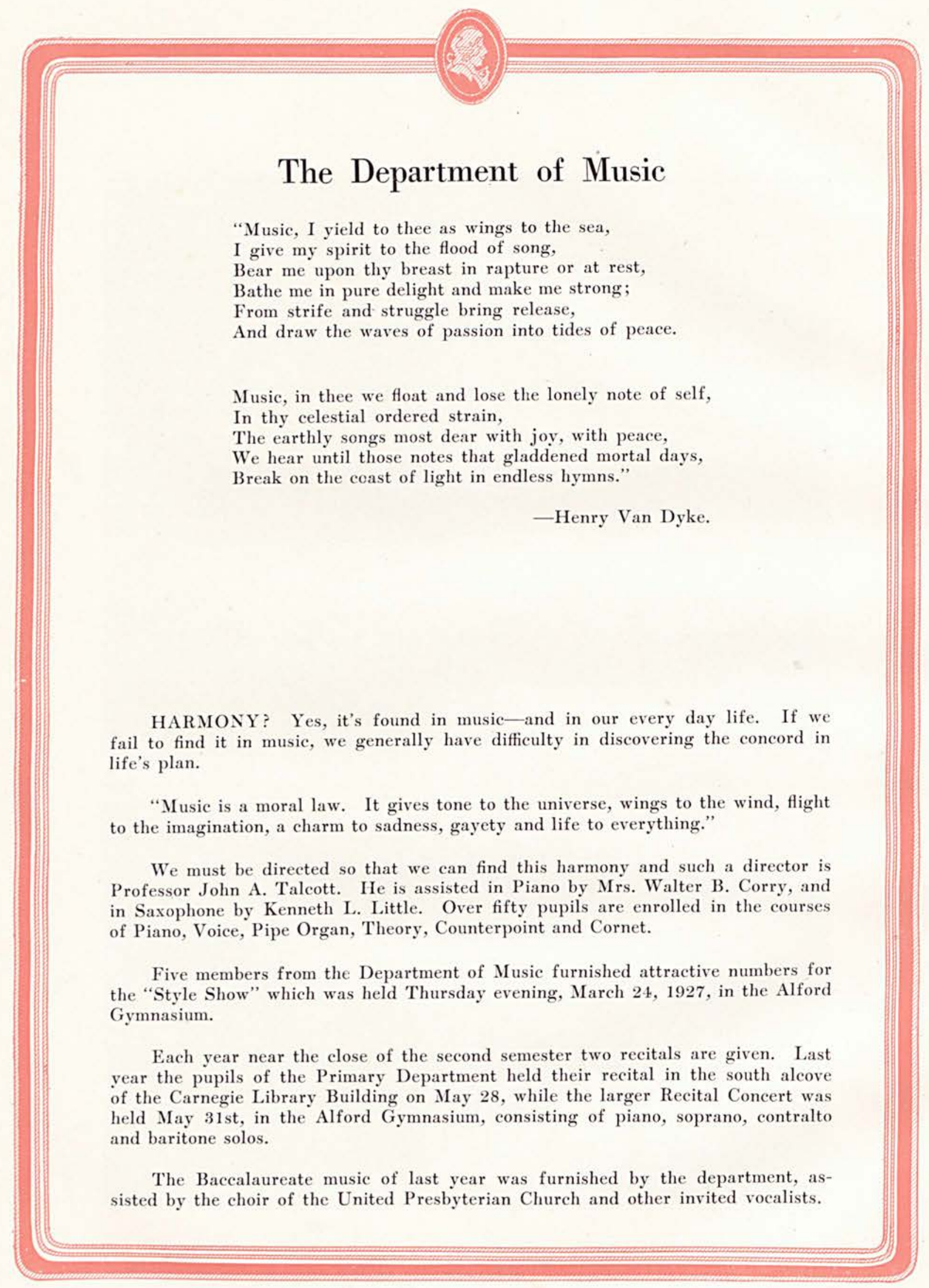

Page Sixty 


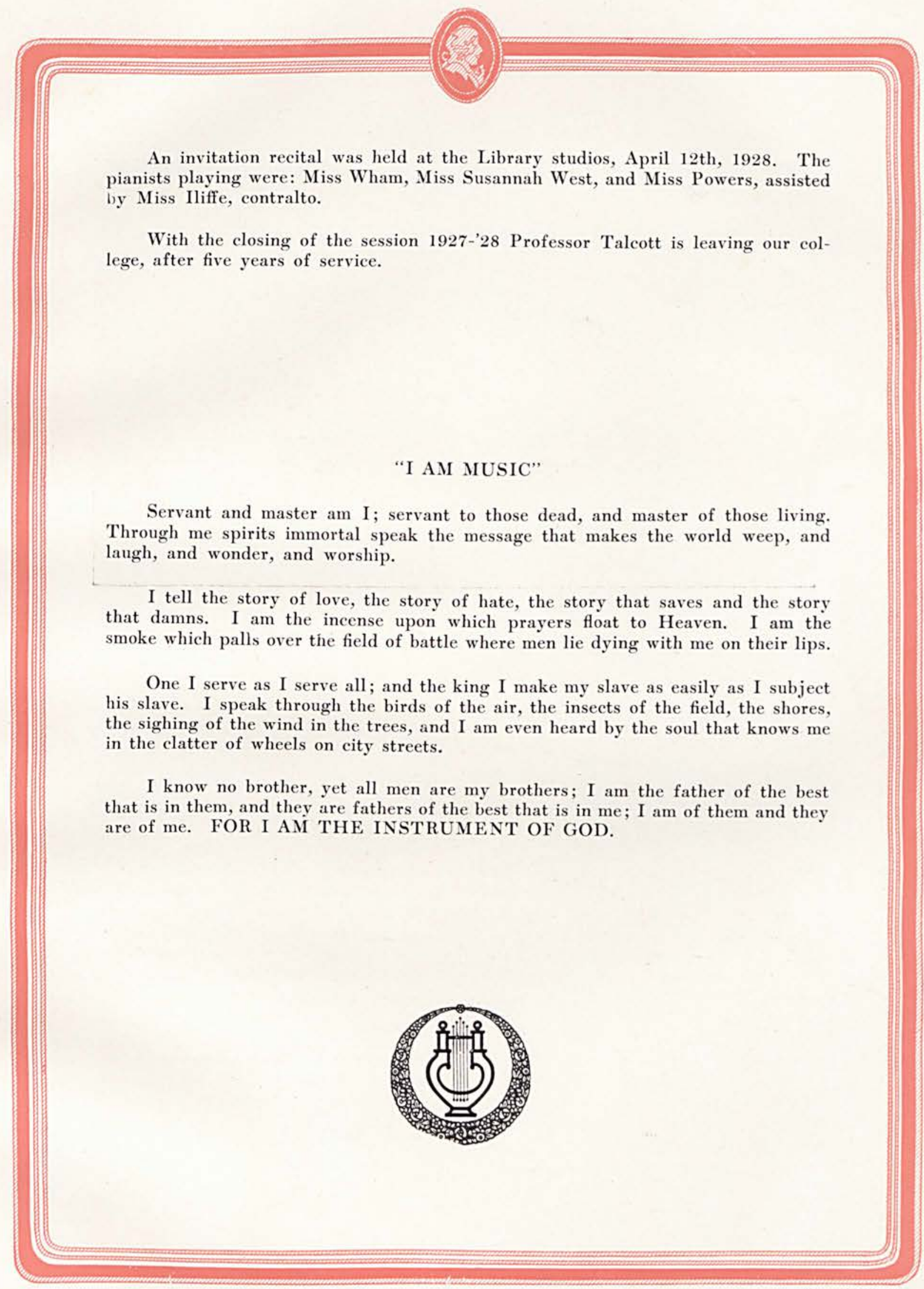

Page Sixty-one 


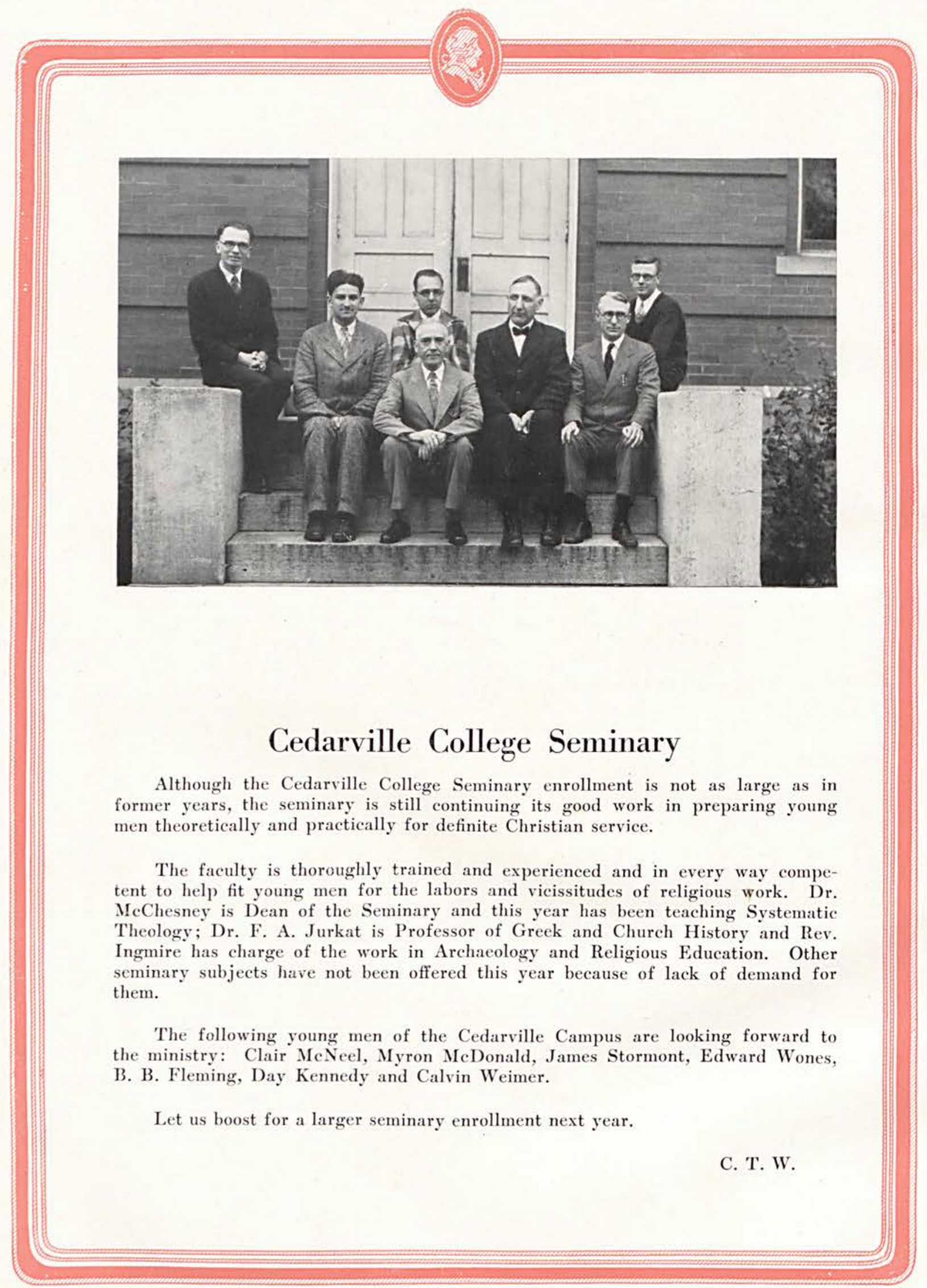

Page Sixty-two 


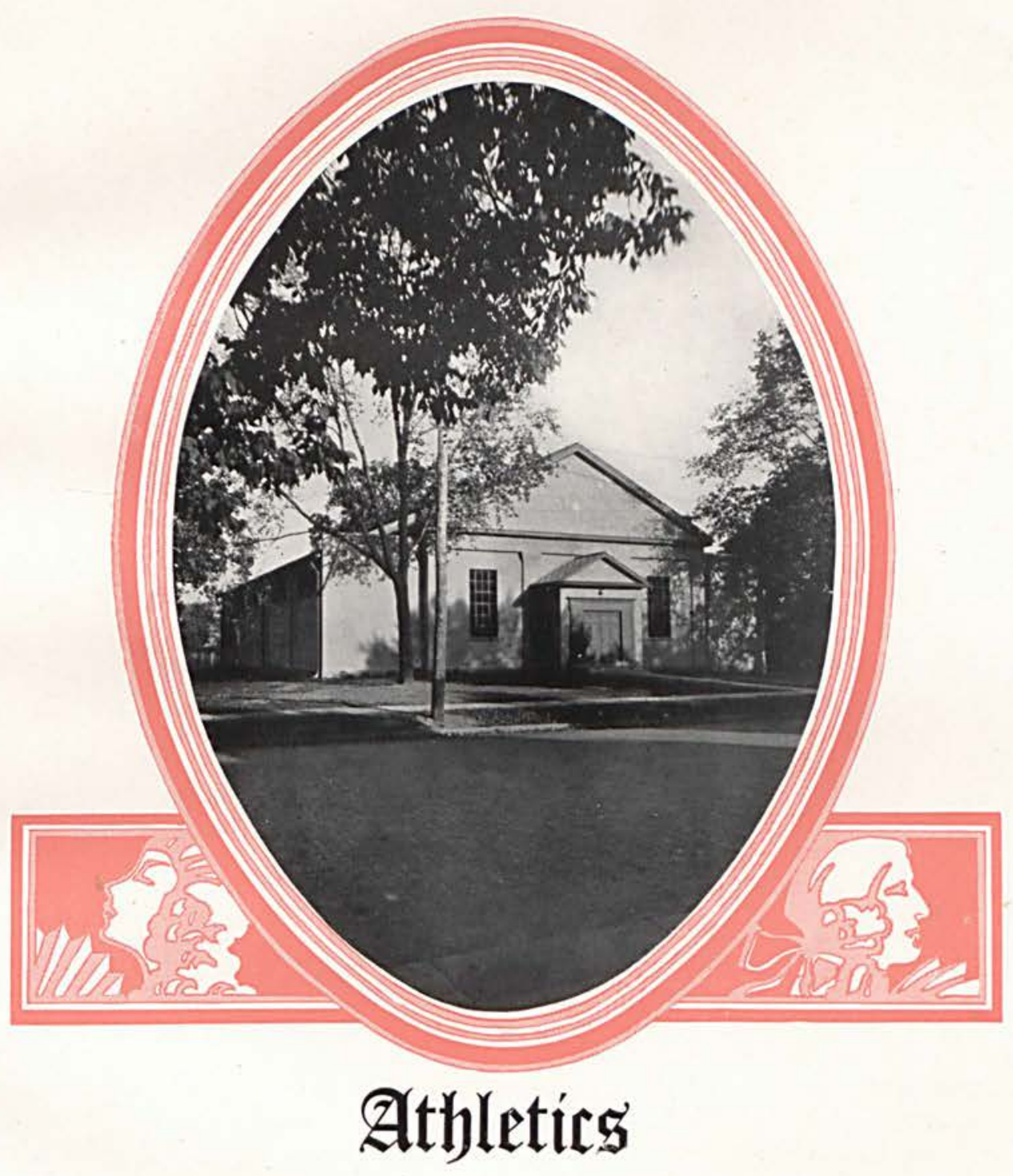





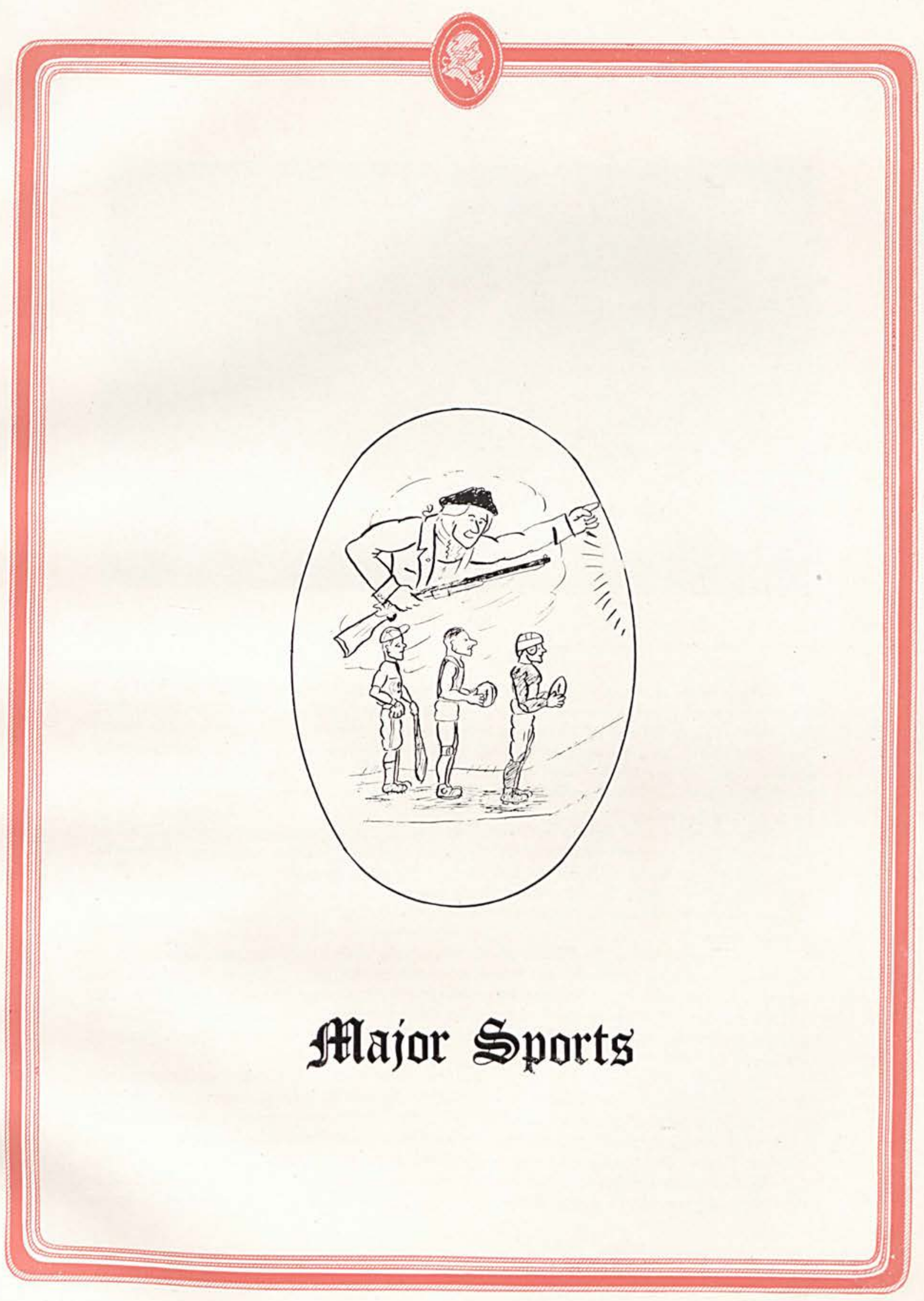




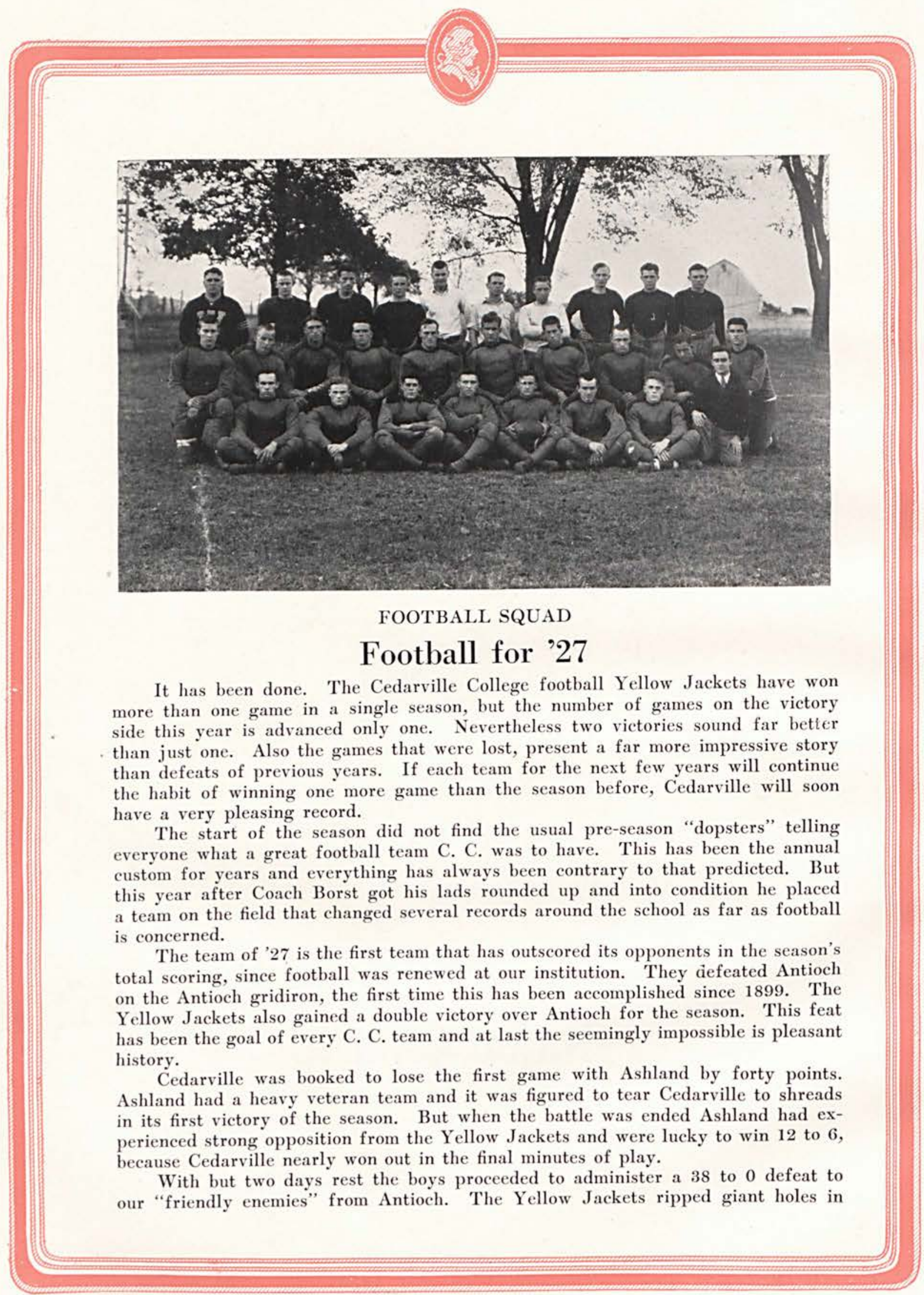

Page Sixty-six 


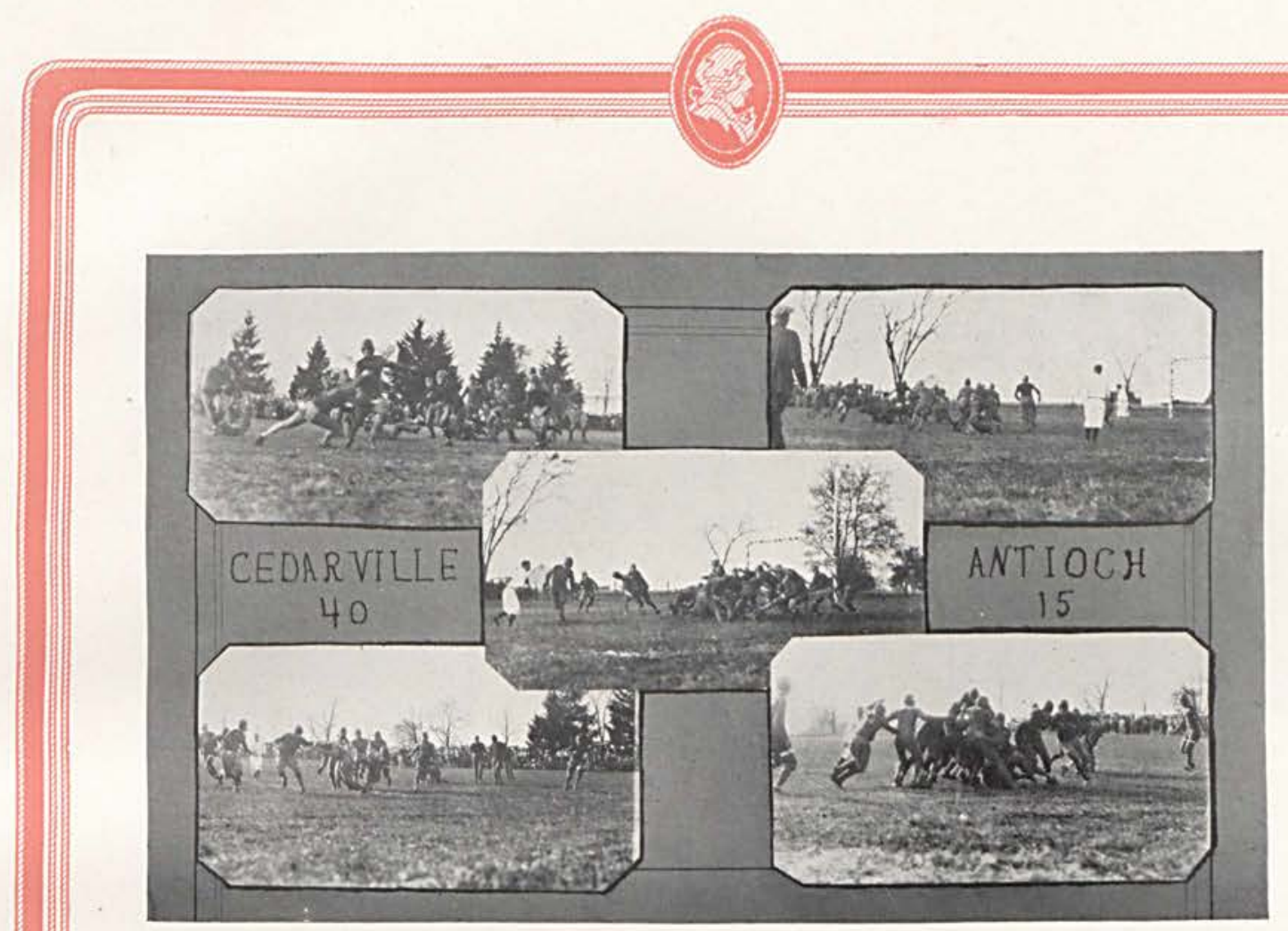

the enemy's line, skirted their ends with ease, and tossed passes over their heads consistently for long gains. Antioch threatened but once during the entire contest; this was just after the game started. The Yellow Jackets called time-out and it was unanimously decided that they form a stone wall defense. These intentions were carried out perfectly. They were so perfect we doubt if all of Antioch could have crushed the wall. As soon as Cedarville received the ball on downs Adair took the ball and zig-zagged through the entire Antioch team, running eighty yards for a touchdown. Late in the last half this same fleet footed Yellow Jacket (no remarks from the Zoologists, please) caused another sensation; the second time though, the jaunt covered a distance of ninety yards.

The following Friday brought on the annual scramble with Capital. This was Cedarville's one grand chance to wallop "Jerry" Katherman and his band of football warriors. Our boys had the far better team; they were supposed to win. Two forgotten feminine folks, though, found their way into the contest and perchance they both settled down in the camp of the Columbus lads. "Dame Fortune" and "Lady Luck" are the ladies mentioned above, in case you have not guessed. Cedarville was leading 7 to 6 . The game was nearly over. Cedarville had cleanly and decisively outplayed their opponents all afternoon. A lucky break was Capital's only chance; and they got it. A diminutive, substitute, Capital end, recovered a Cedarville fumble. He tucked the ball in his arms and with the speed of three scared antelopes struck out for the goal line; the farther he ran the faster he ran. Capital 12, Cedarville 7. This little "unknown" had brought sudden and unexpected hilarity to the Capital stands and caused more sudden and unexpected gloom in the Cedarville group. Cedarville made another touchdown on the last play of the game, but after the timekeepers, umpire and referee got together they decided the game had ended with the preceding play. Just another football game lost by C. C. That's all.

The next week unearthed another game lost by one touchdown. Someone must have clipped the Yellow Jackets wings because they got off to a very poor start. 


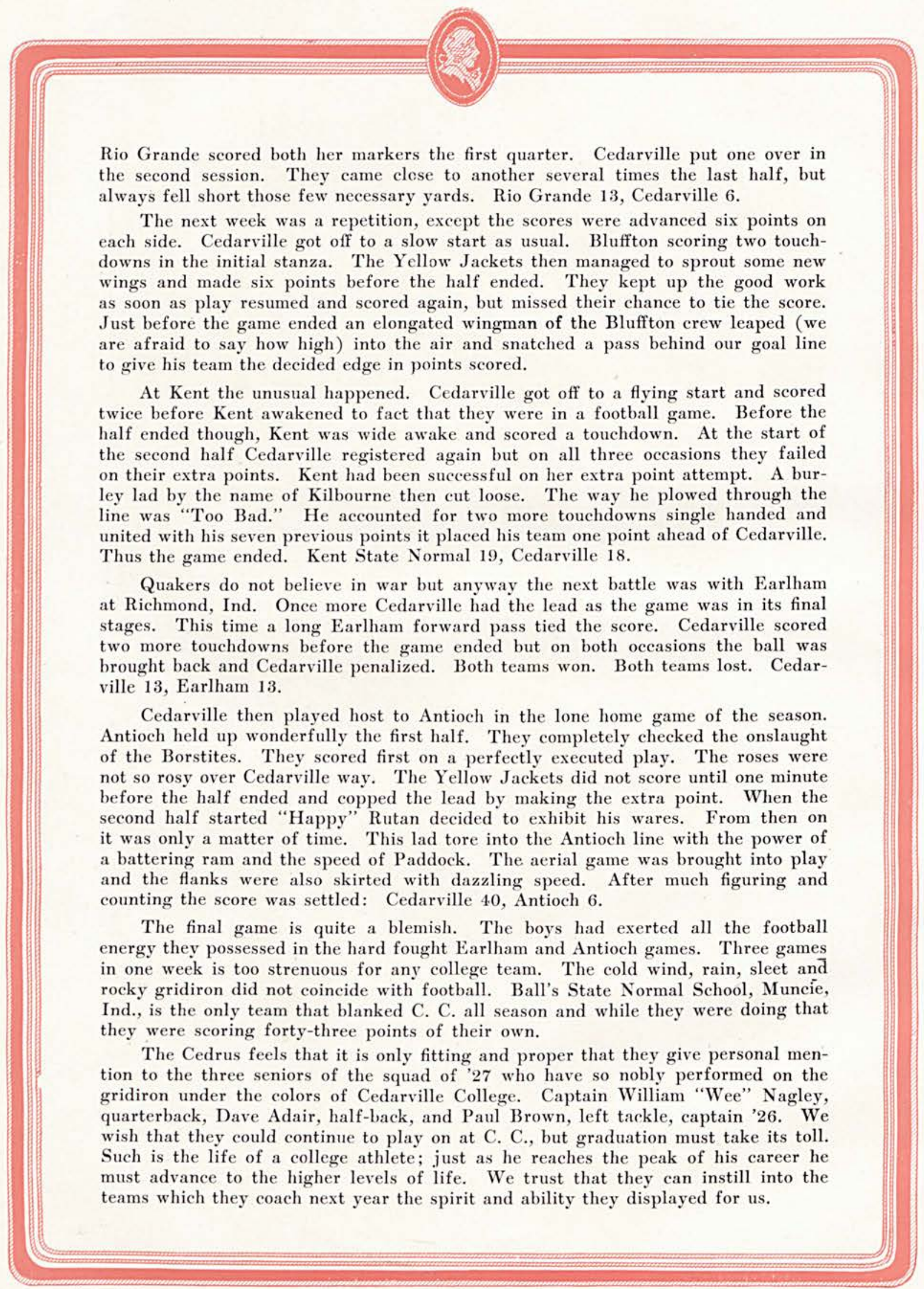

Page Sixty-eight 


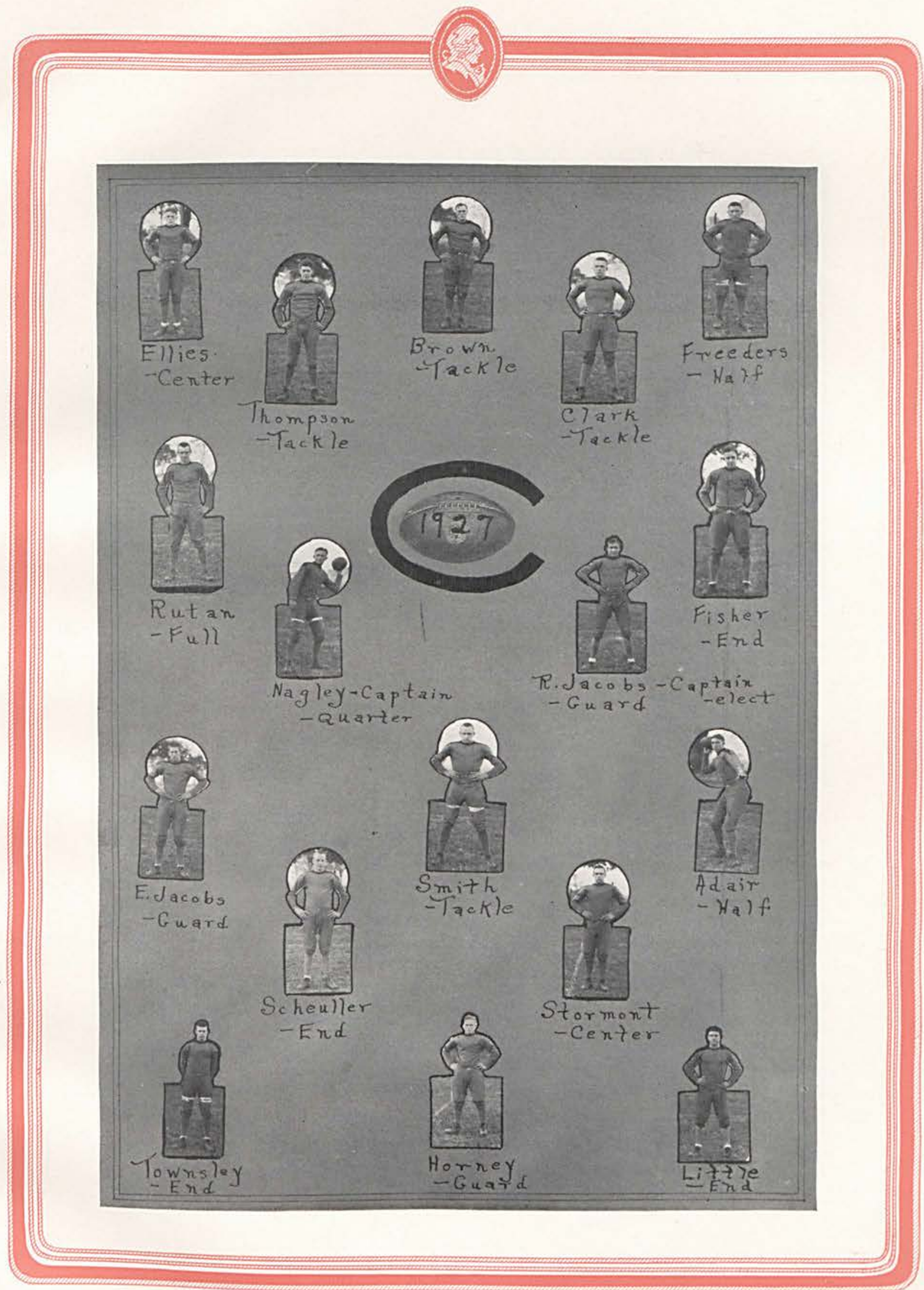




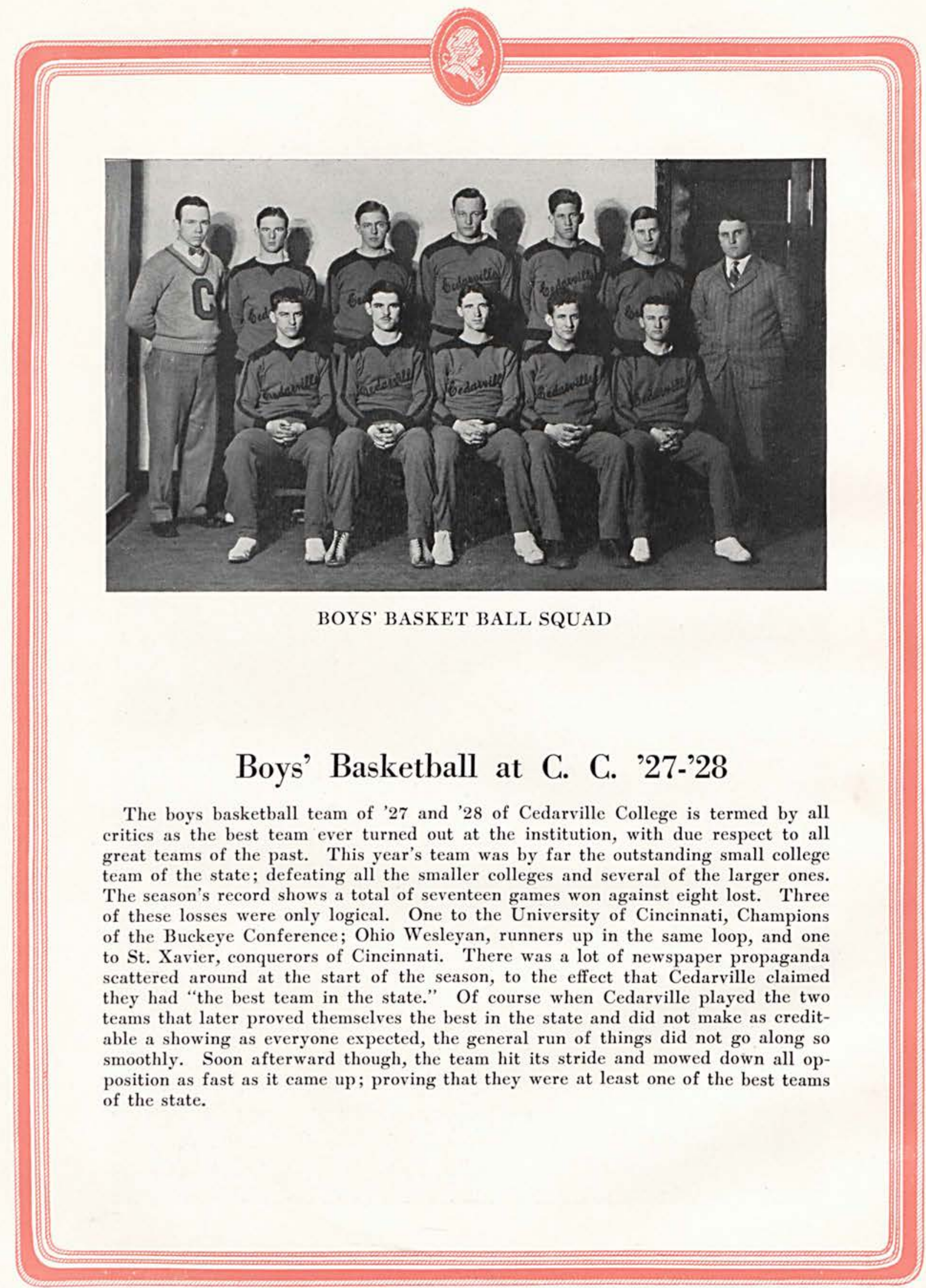

Page Seventy 


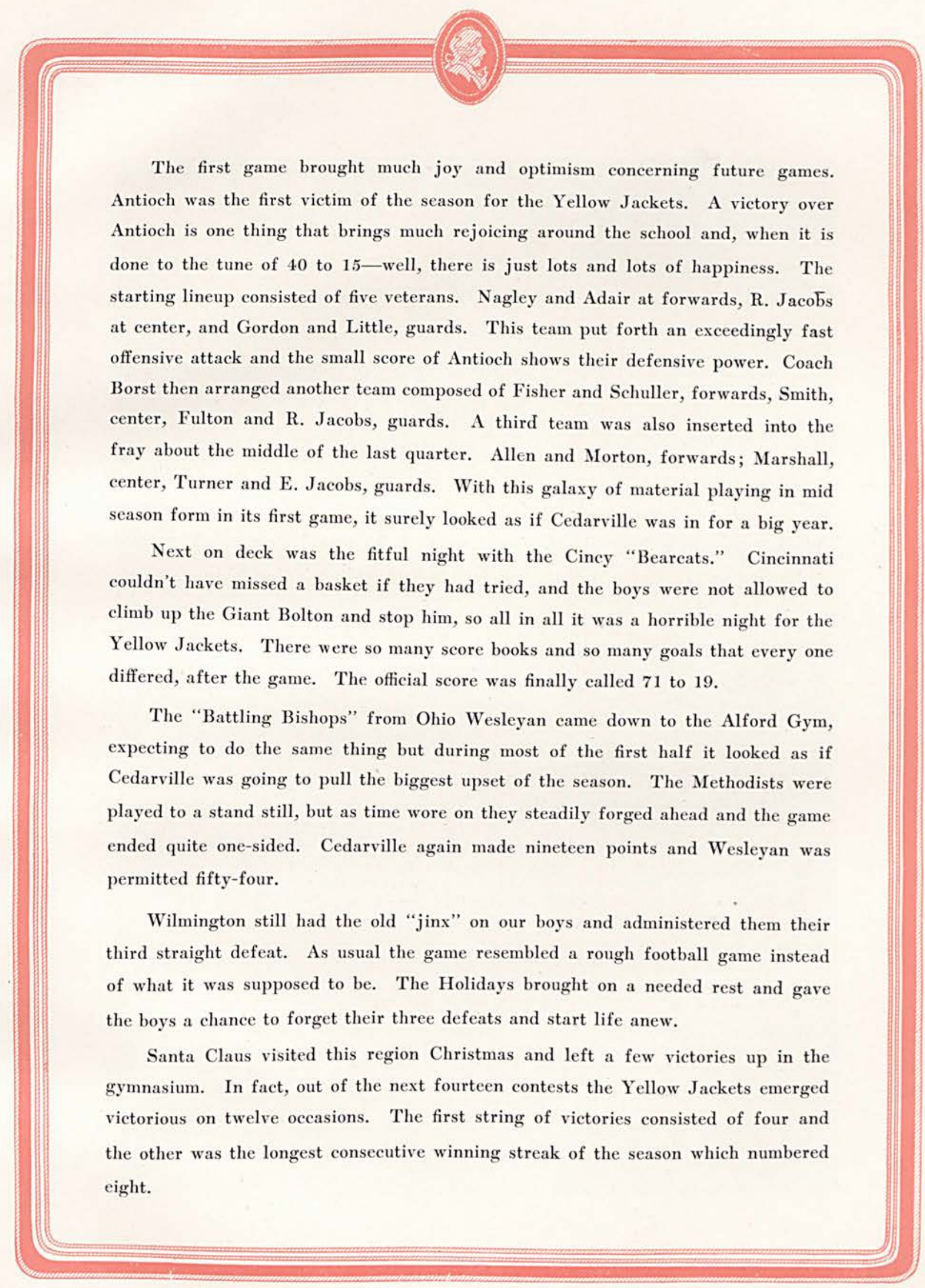

Page Seventy-one 


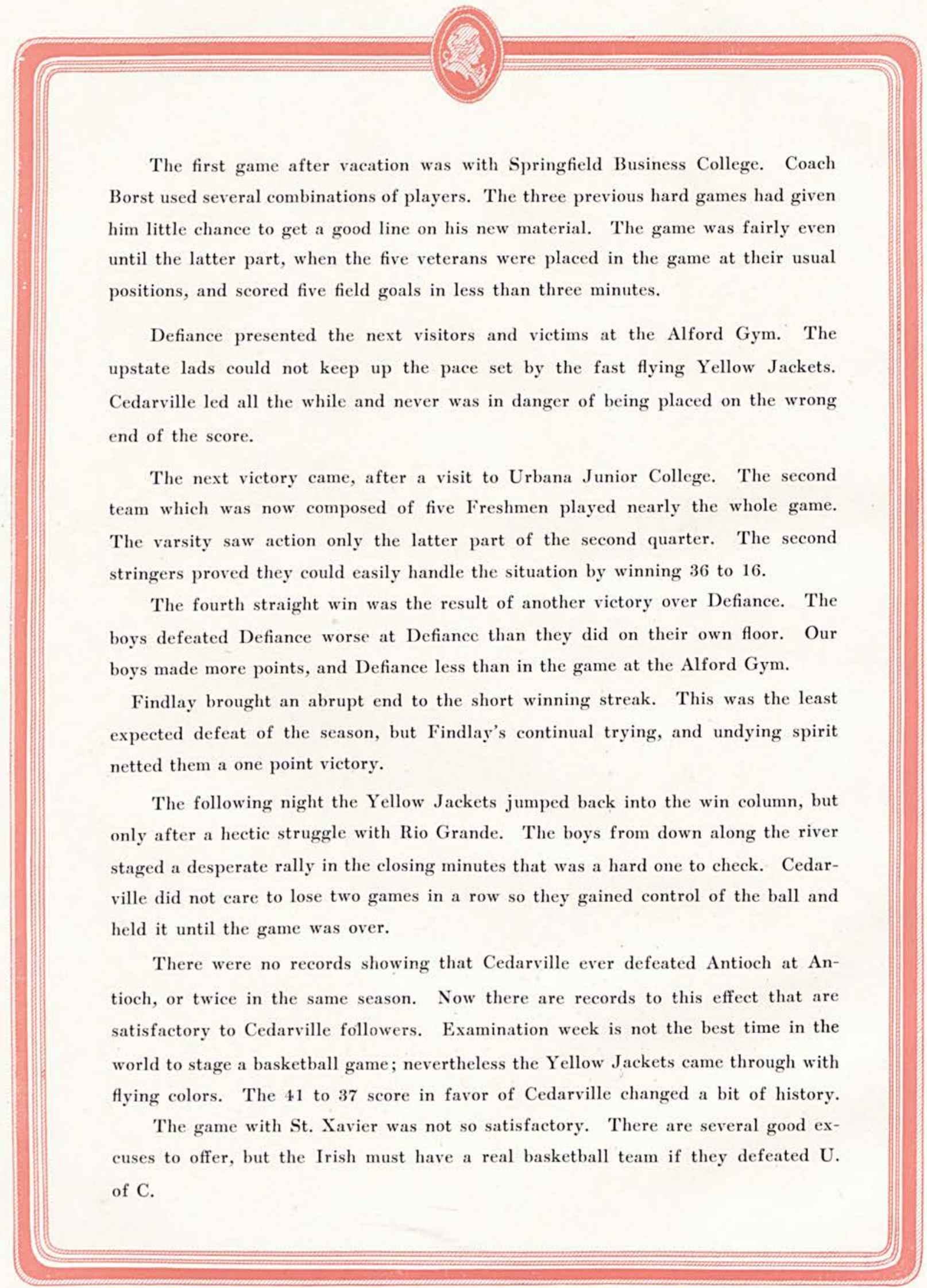

Page Seventy-two 


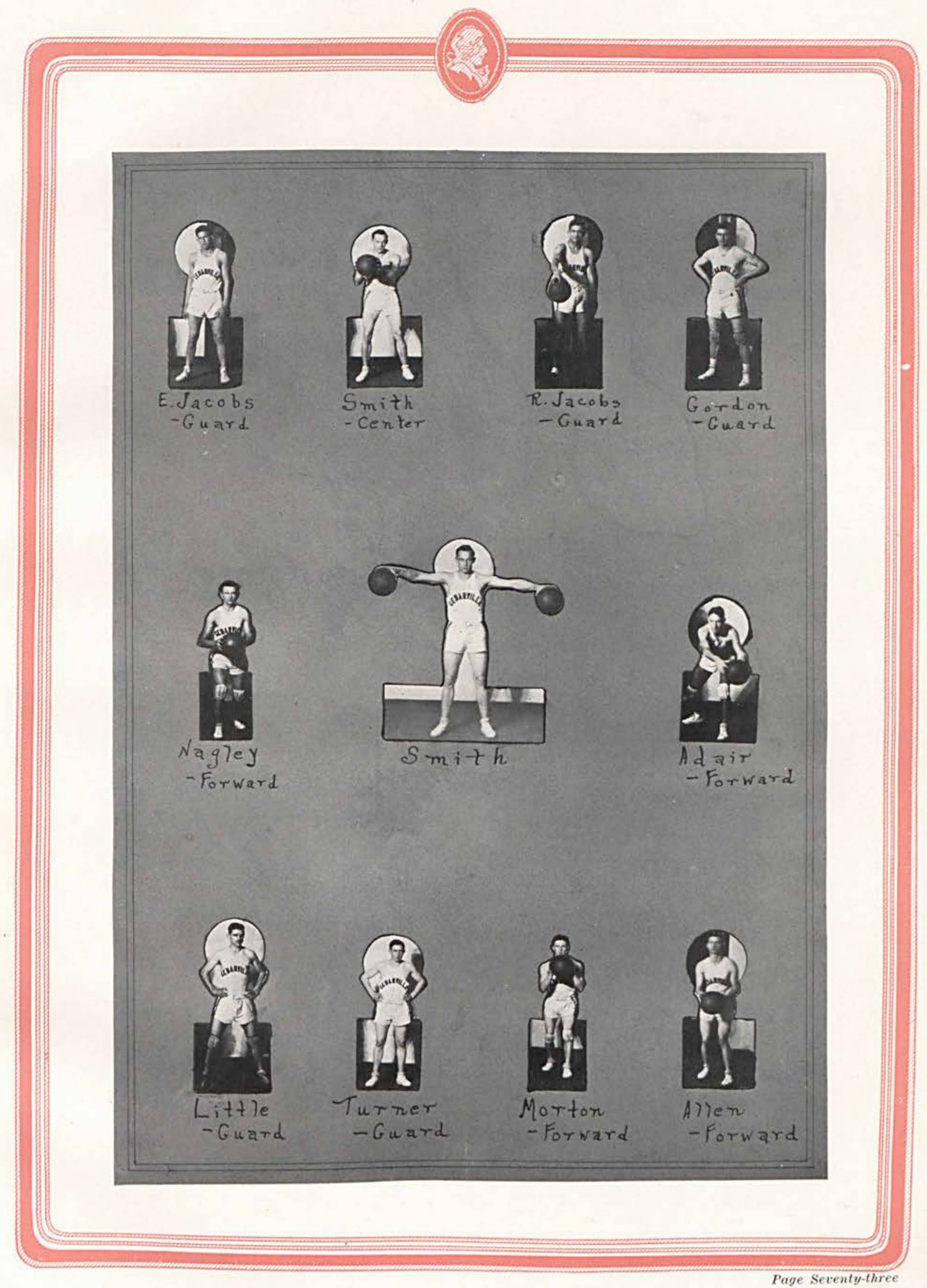




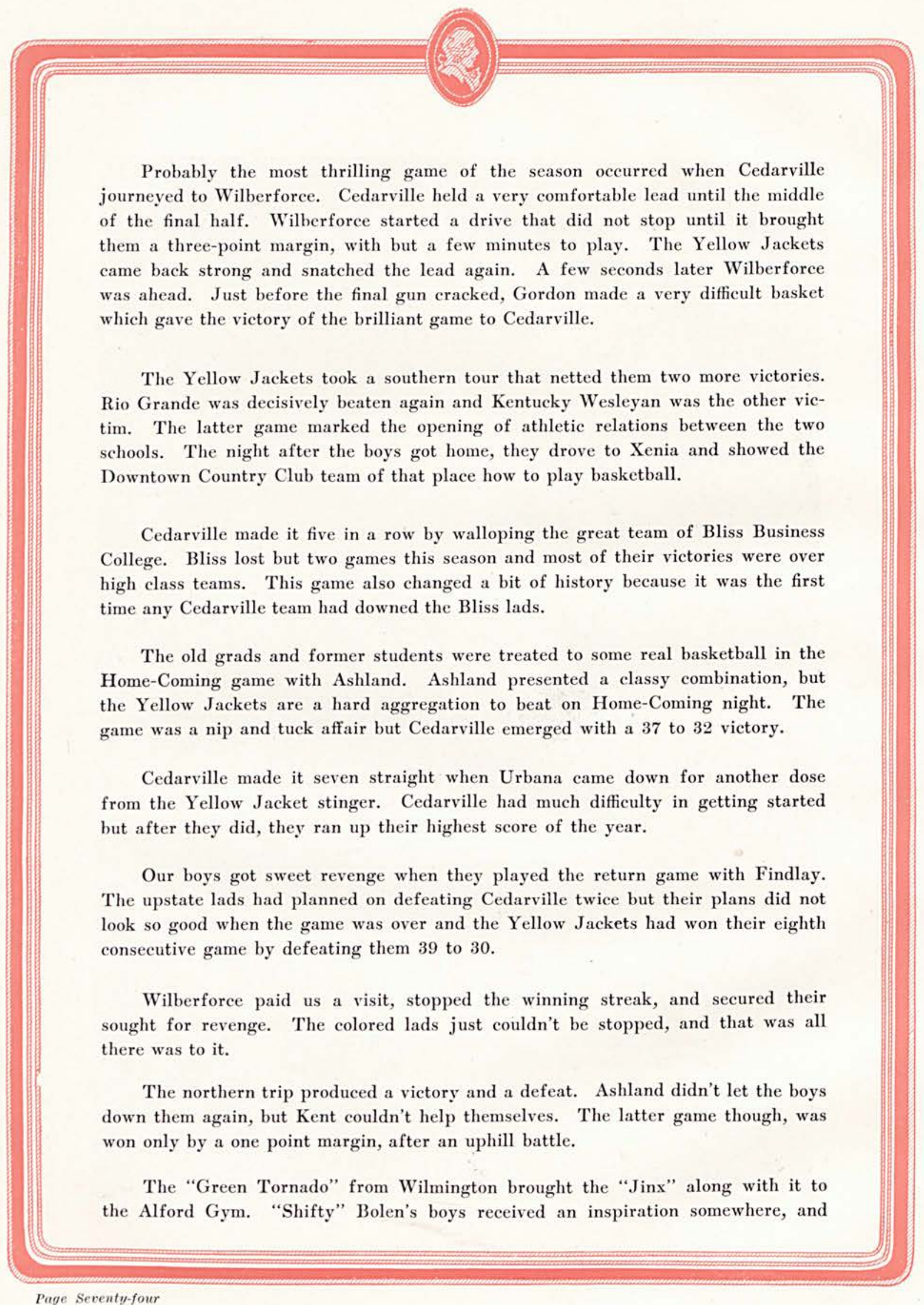

Page Seventy-four 



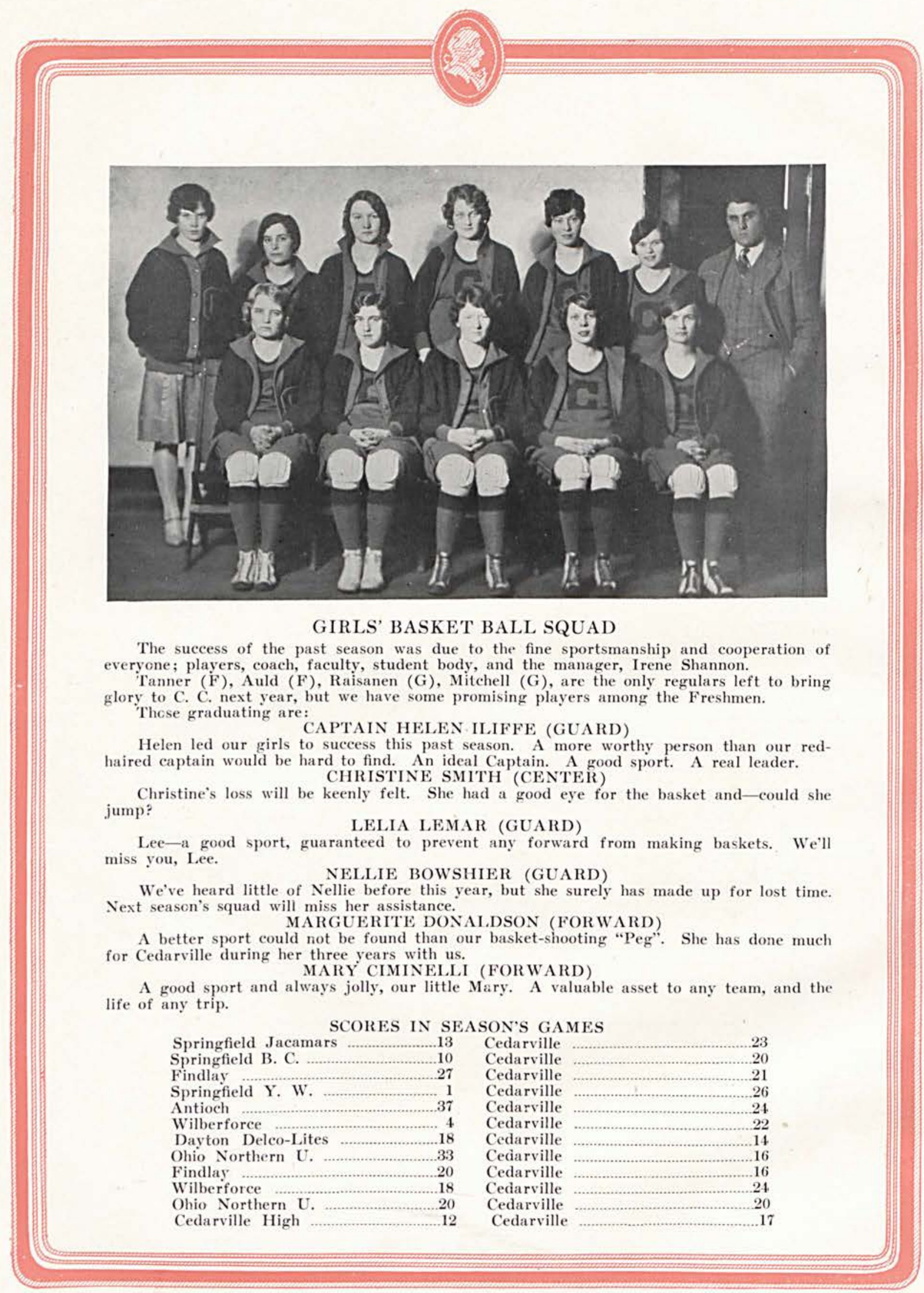

Paye Seventy-six 


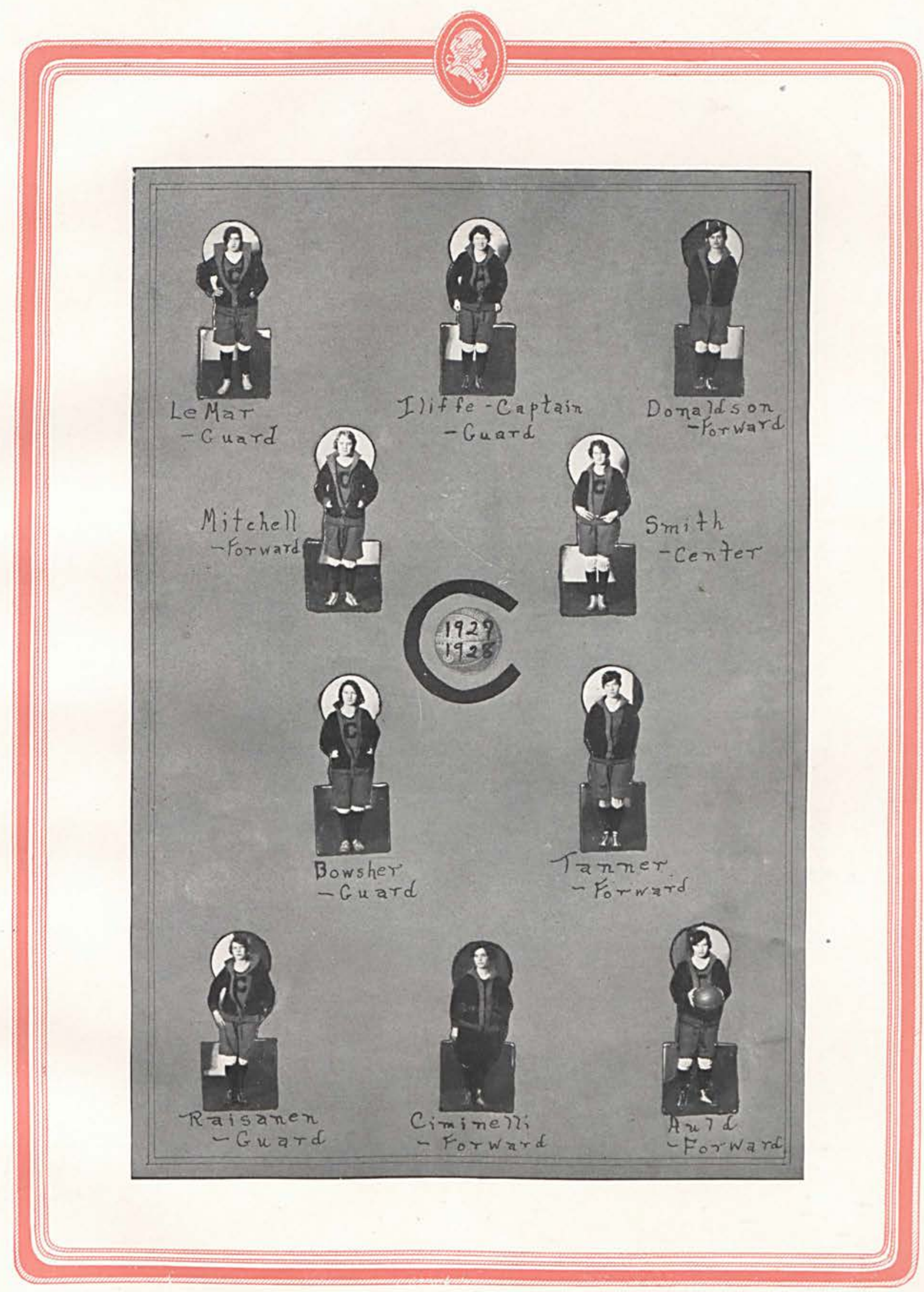

Page Seventy-seven 


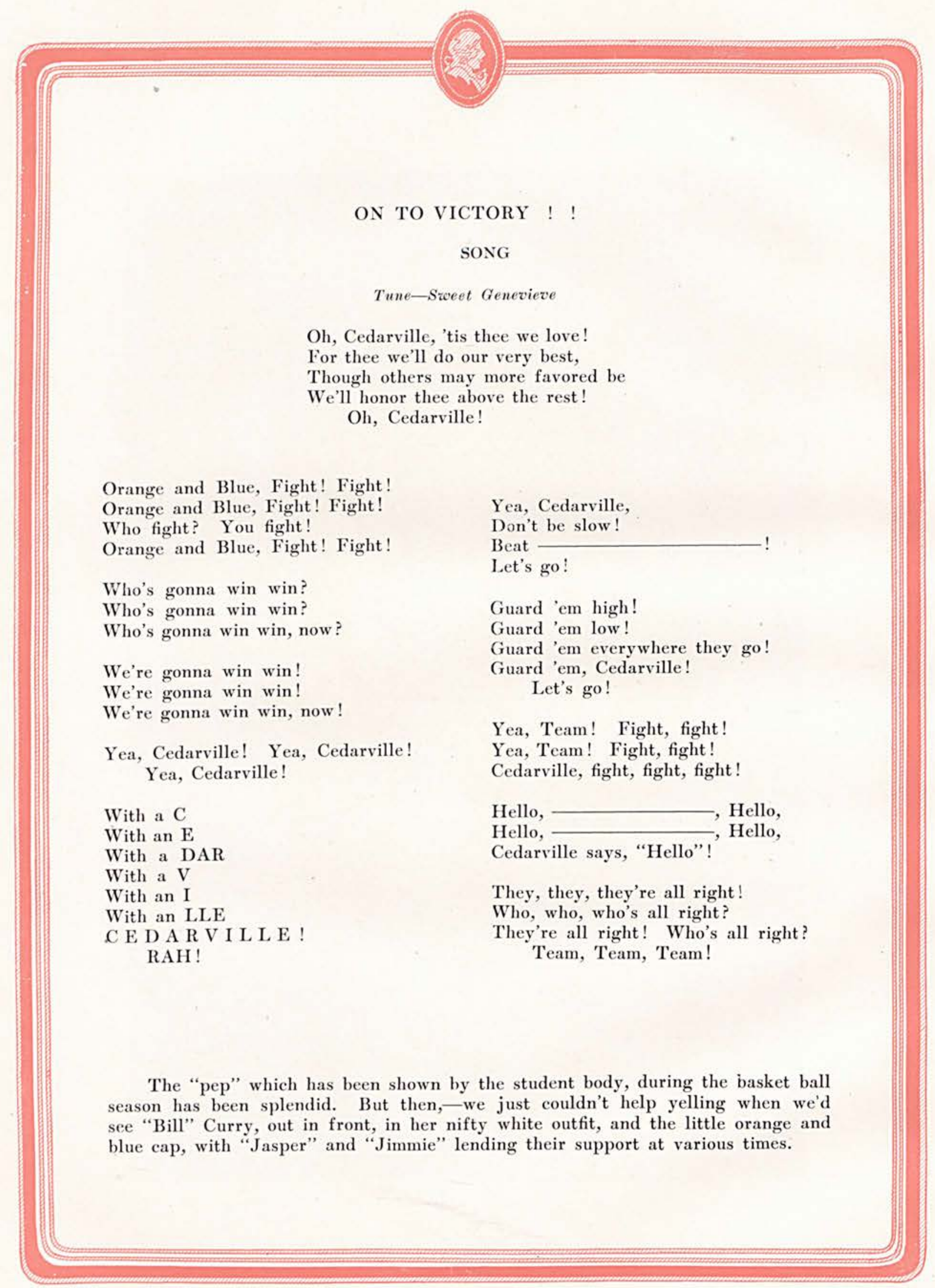

Page Seventy-eight 


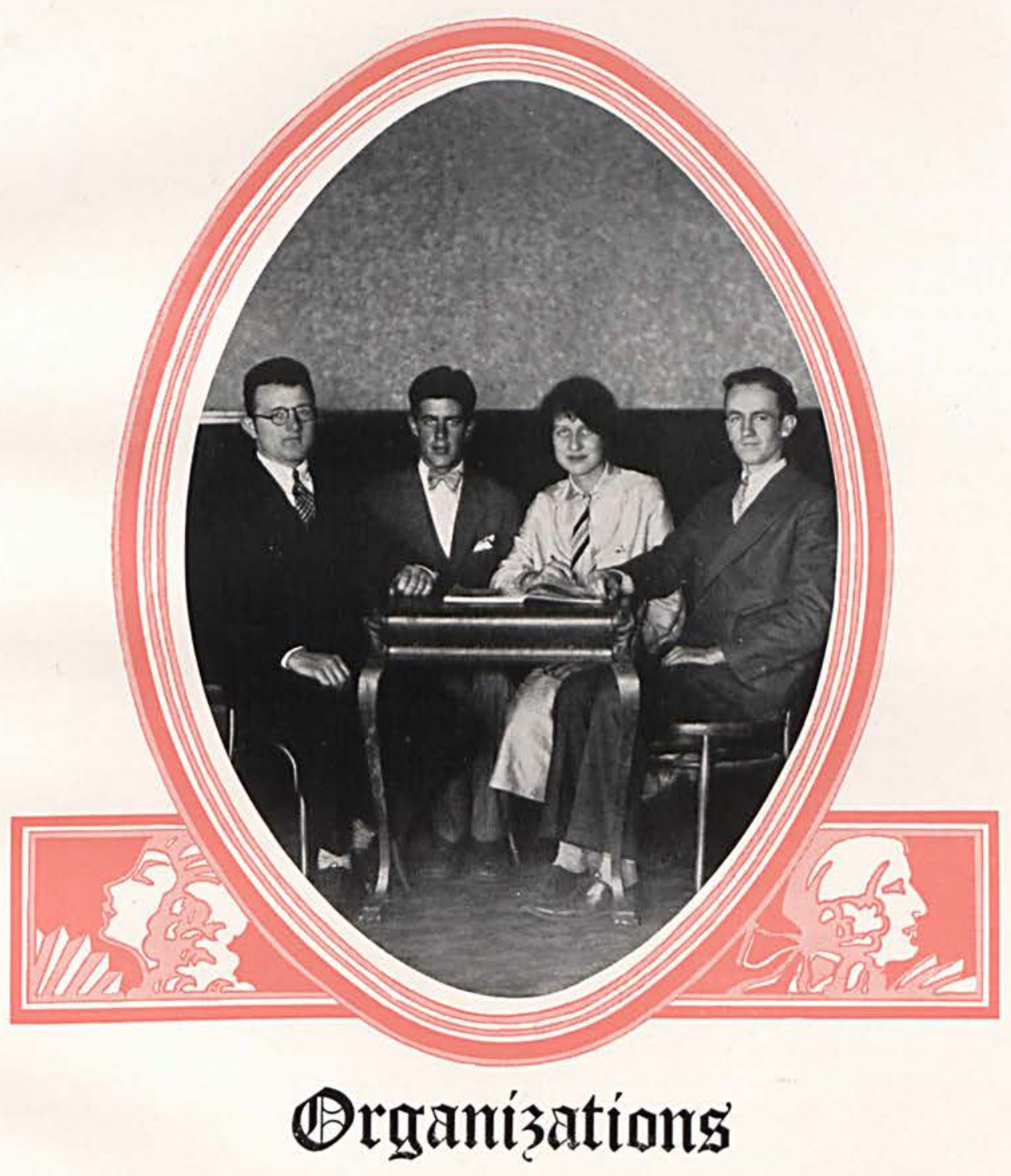




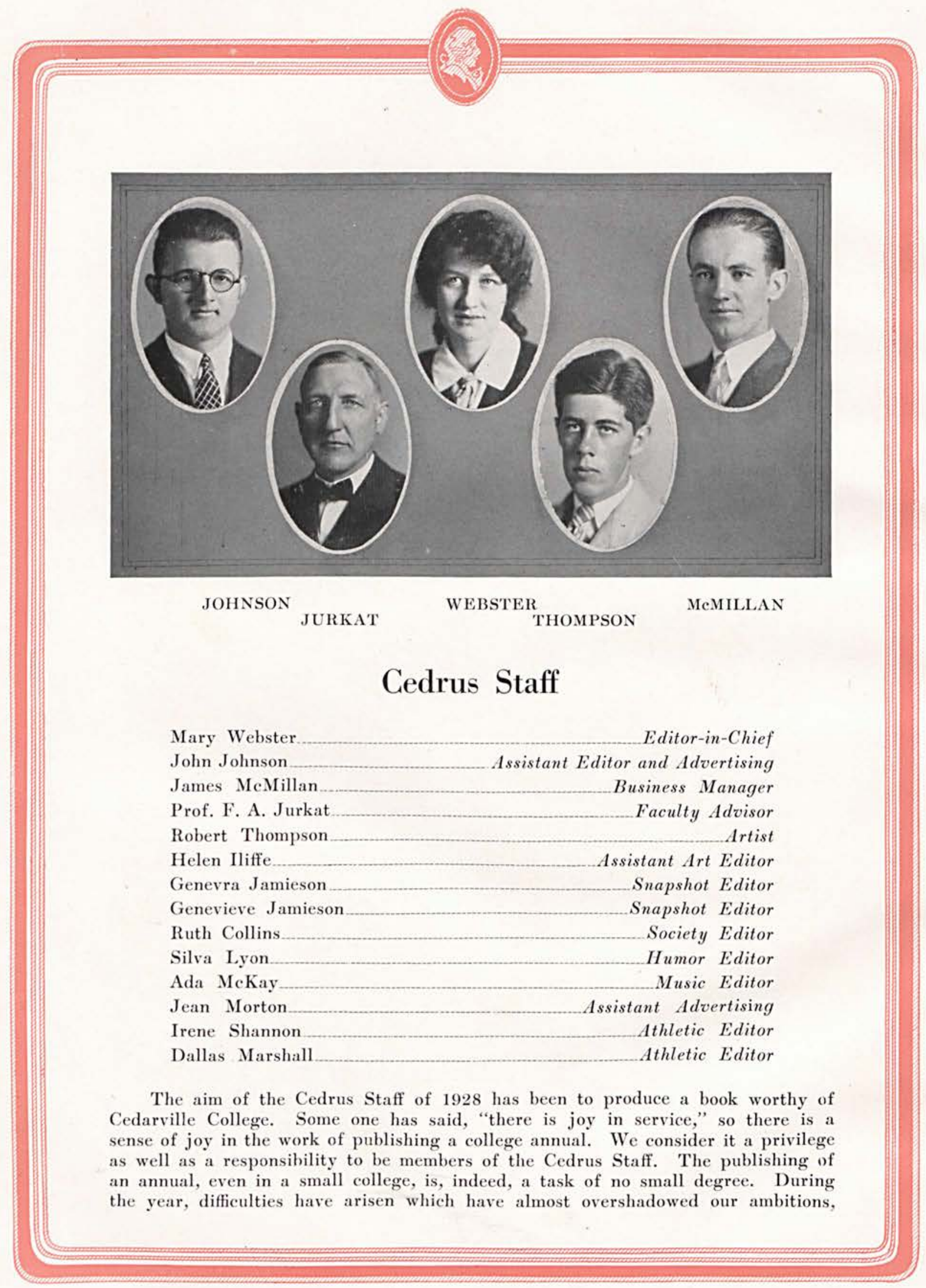




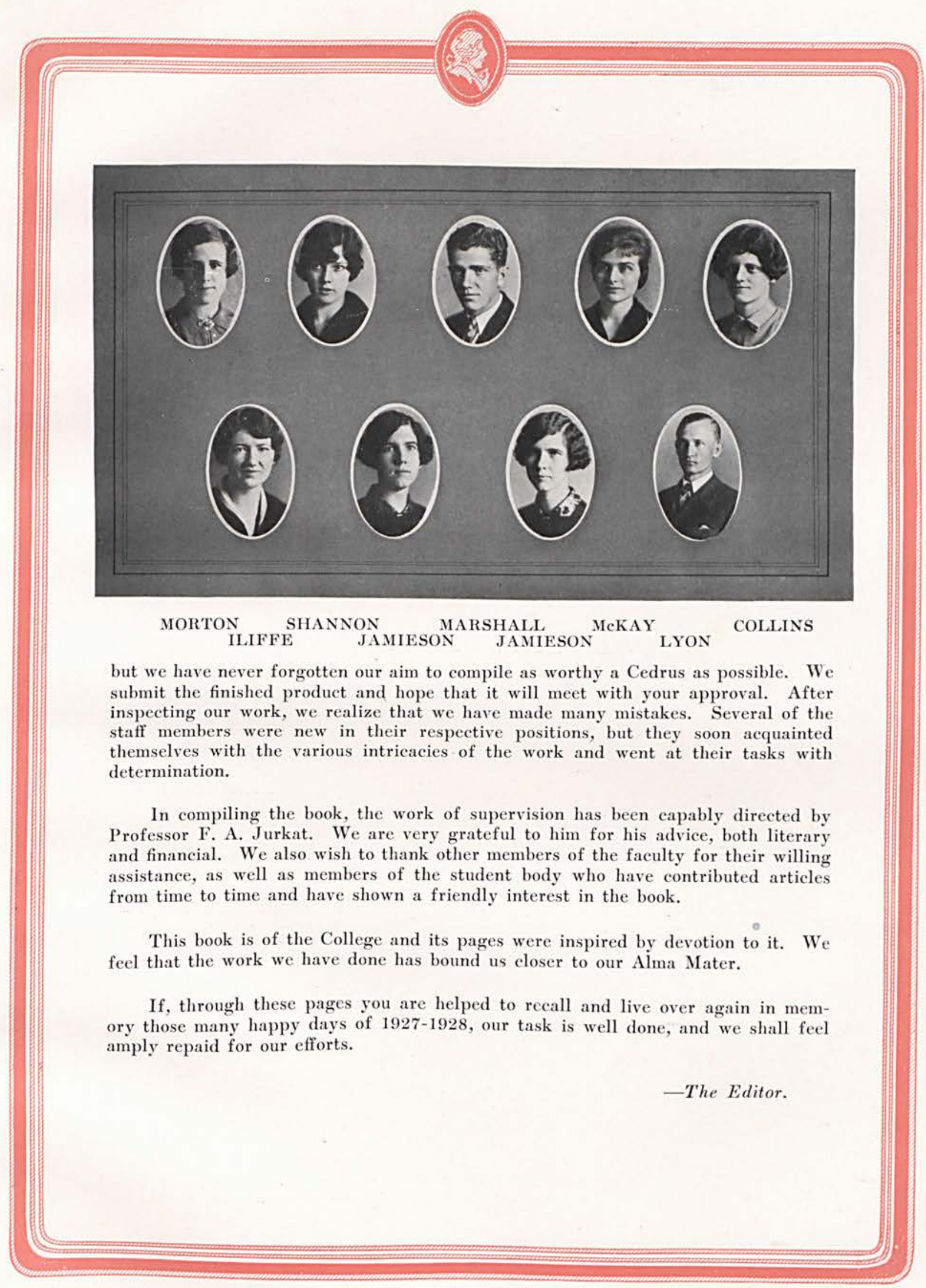

Page Eighty-one 


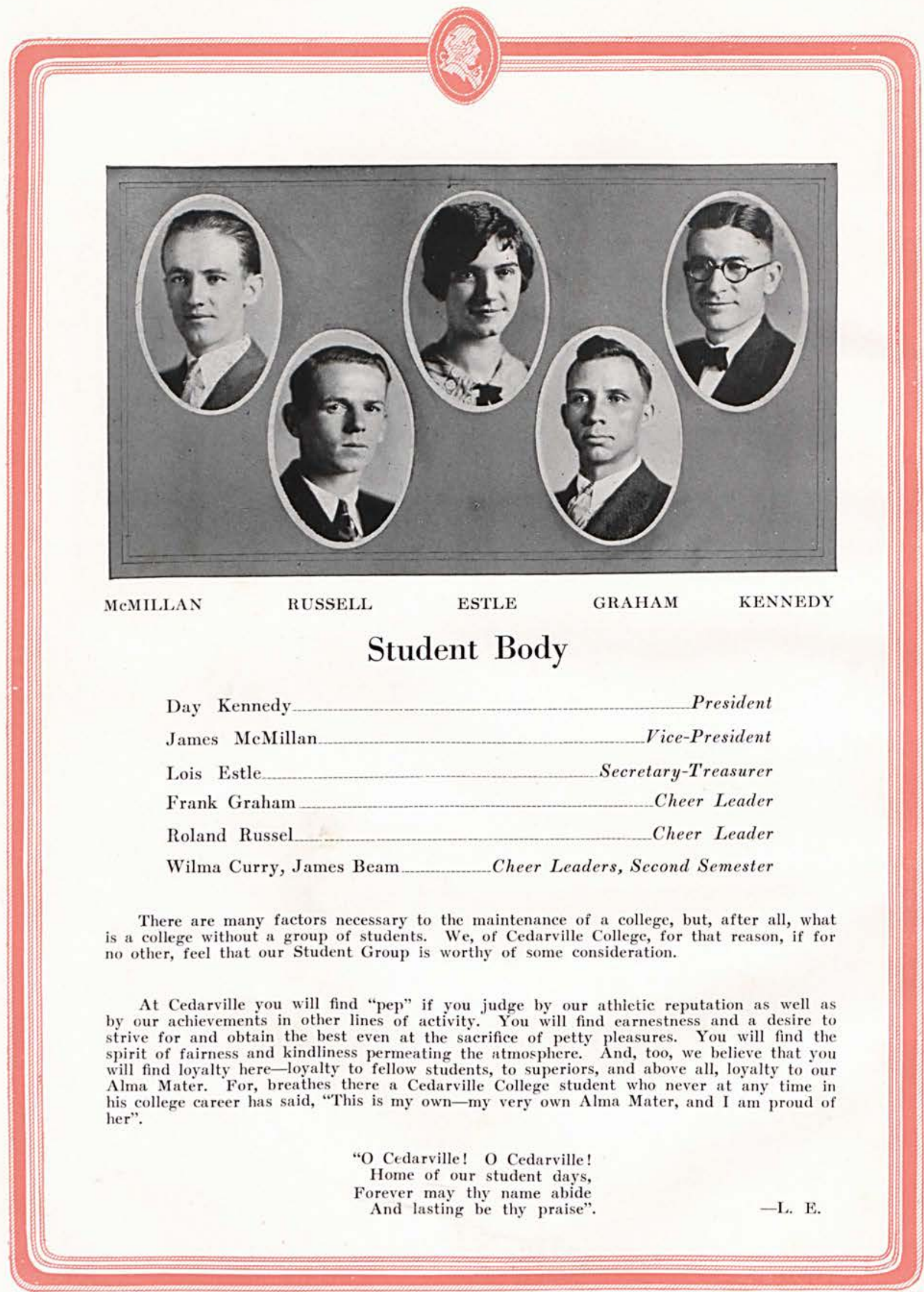

Page eighty-two 


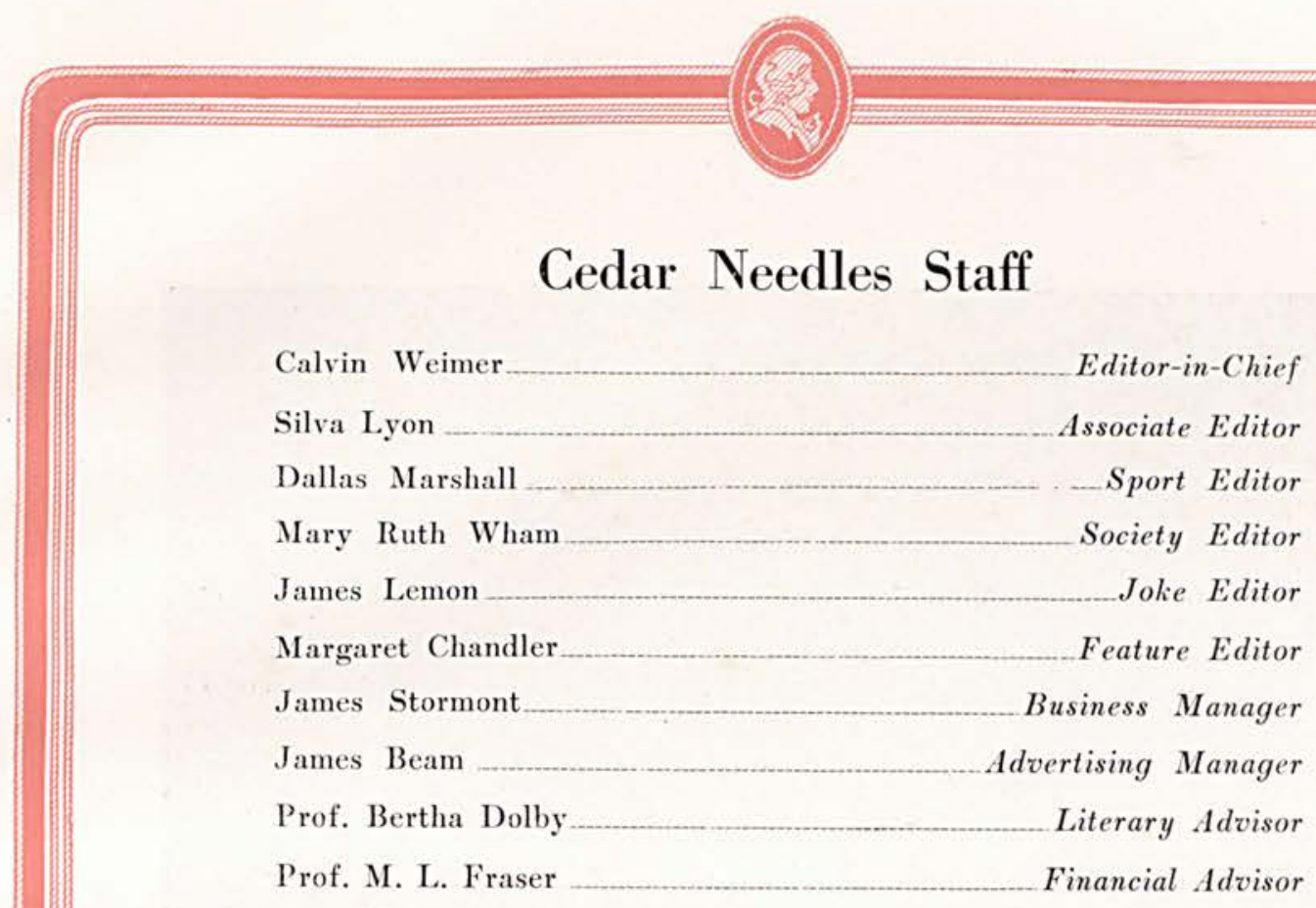

During the year, the place of Cedar Needles on the college campus has become well established, due to the efforts of those in charge of the work, and the co-operation of the faculty, student body, and community.

At the beginning of the year, the paper was edited and published by a staff composed of members of the Journalism Classes under the direction of Miss Dolby, and considerable progress was made.

To place Cedar Needles on the full basis of a student college publication, at the outset of the second semester a new staff was selected from the entire student body to carry on the work. Several new departments were created and each staff member was made wholly responsible for all articles within the sphere of his department.

Under this new form of organization and operation, the staff took up its work eagerly and earnestly, with the desire to give their very best to the project, and a determination to make Cedar Needles a most potent factor for good on the Cedarville College Campus.

Whether this has been achieved, the student body is the best judge.

Those interested in the Needles cannot but be of the opinion that it is still in its infancy and that its best days lie ahead. $-\mathrm{C}$. T. W. 


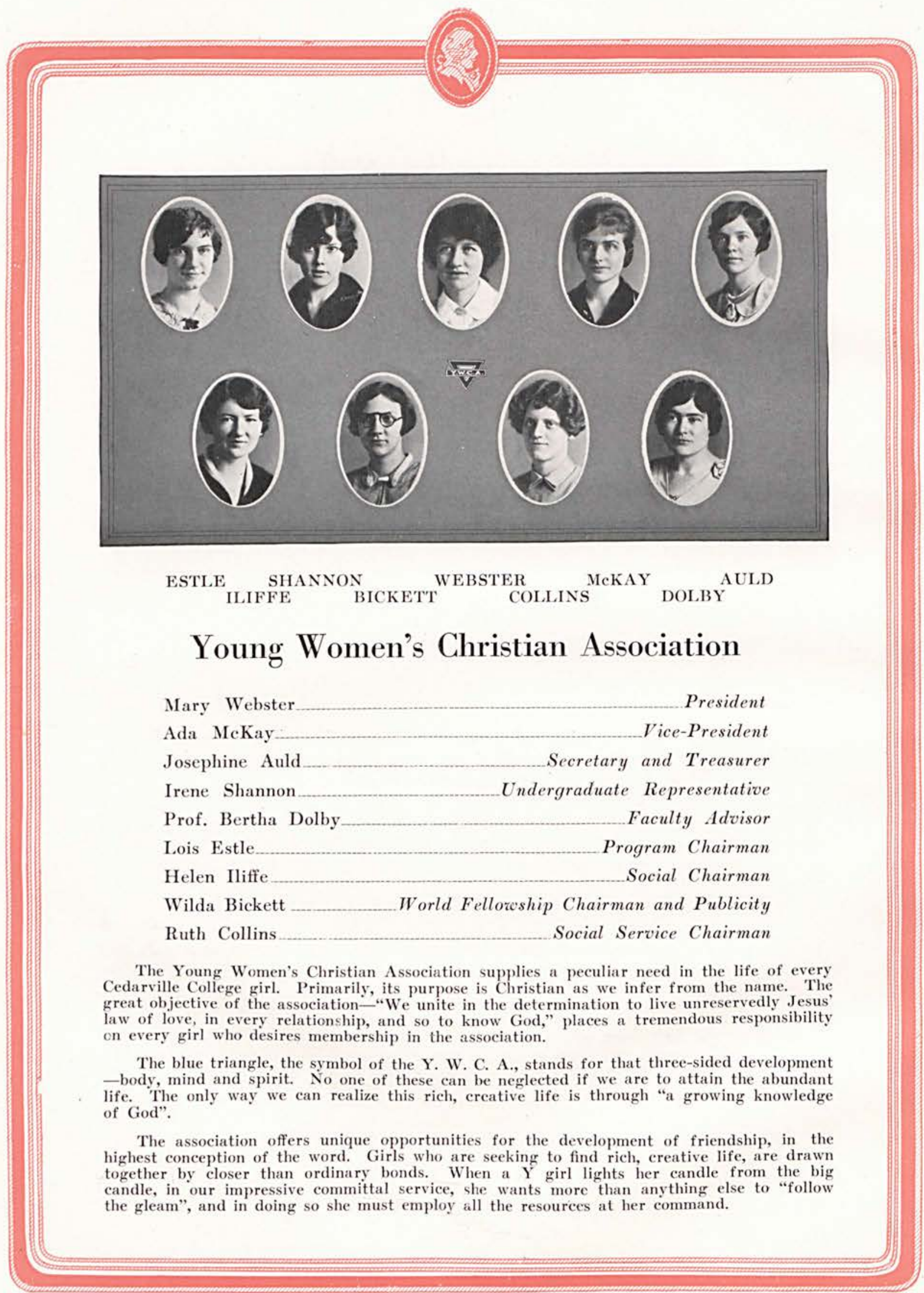

Page Eighty-four 


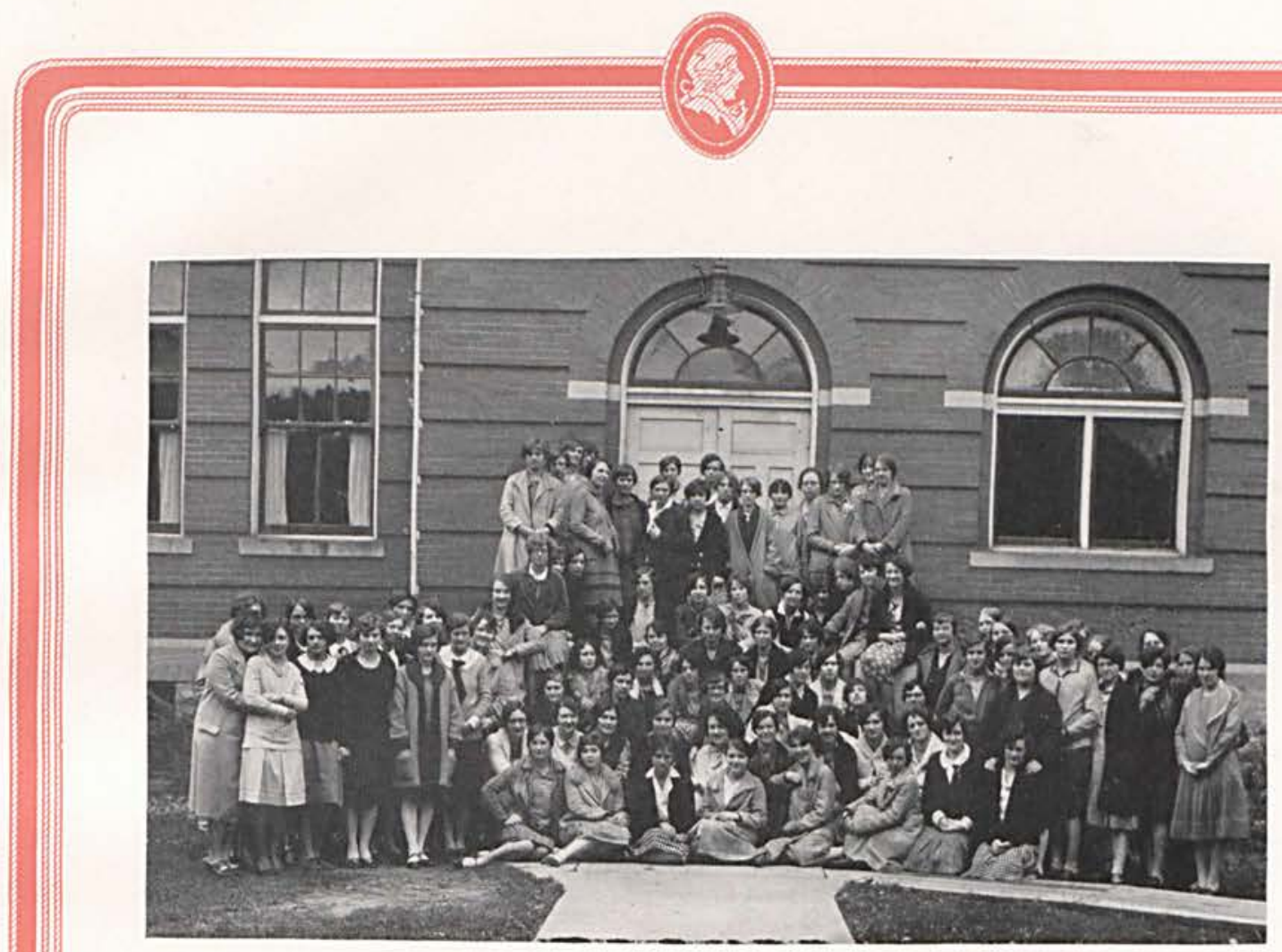

Our association at Cedarville College attempts to guide girls in seeking to find the abundant life. For this reason, our meetings have been varied. During the first part of the year, in our regular Wednesday morning meetings, we discussed the meaning of membership in the Y. W. C. A., its purpose and activities, both as a National organization and also as a student organization in our school.

In order that we might know more about students of other lands, our World Fellowship Chairman led in the discussion of the book- "Latin American Peoples". Another interesting program, brought through this same department, was that given by the Wilberforce Quartet, in song and story.

The second semester we considered four big projects

Travel (A trip from Cedarville to Europe).

When It's Hard to be a Christian.

Etiquette.

Girls Who Did

It is hard to choose those social activities which we want to remember. However, some are outstanding. The Welcome Tea given the opening day of College; the informal breakfast given by the Cabinet at the beginning of the membership campaign, and attended by every girl in college; the Hallowe'en Party, given by the Y. M.; the joint Valentine Party; the formal banquet, addressed by Dr. Auleene Marley Jamison, Dean of Women at Muskingum College; and the girls' Mock Wedding.

As a part of our social service work, we remember the needy with well-filled baskets every Thanksgiving. Three programs have been open to members of the community-the Committal Service, our Christmas program and the Silver Tea.

Our visions were broadened by Miss Maude Gwinn, National Student Secretary, who visited us for two days. Aside from speaking to a group of the girls, Miss Gwinn was available for private conferences. The Cabinet entertained at a dinner in Miss Gwinn's honor.

The president of the association and the faculty advisor were privileged to attend the Geneva Conference, during the summer months. It is the ambition of this year's cabinet that a larger delegation attend the conference this summer; for there, every girl has the experience of ten days of "real living", and she returns to her own campus with a fuller realization of the Y. W. C. A. in all its activities. -M. W. 


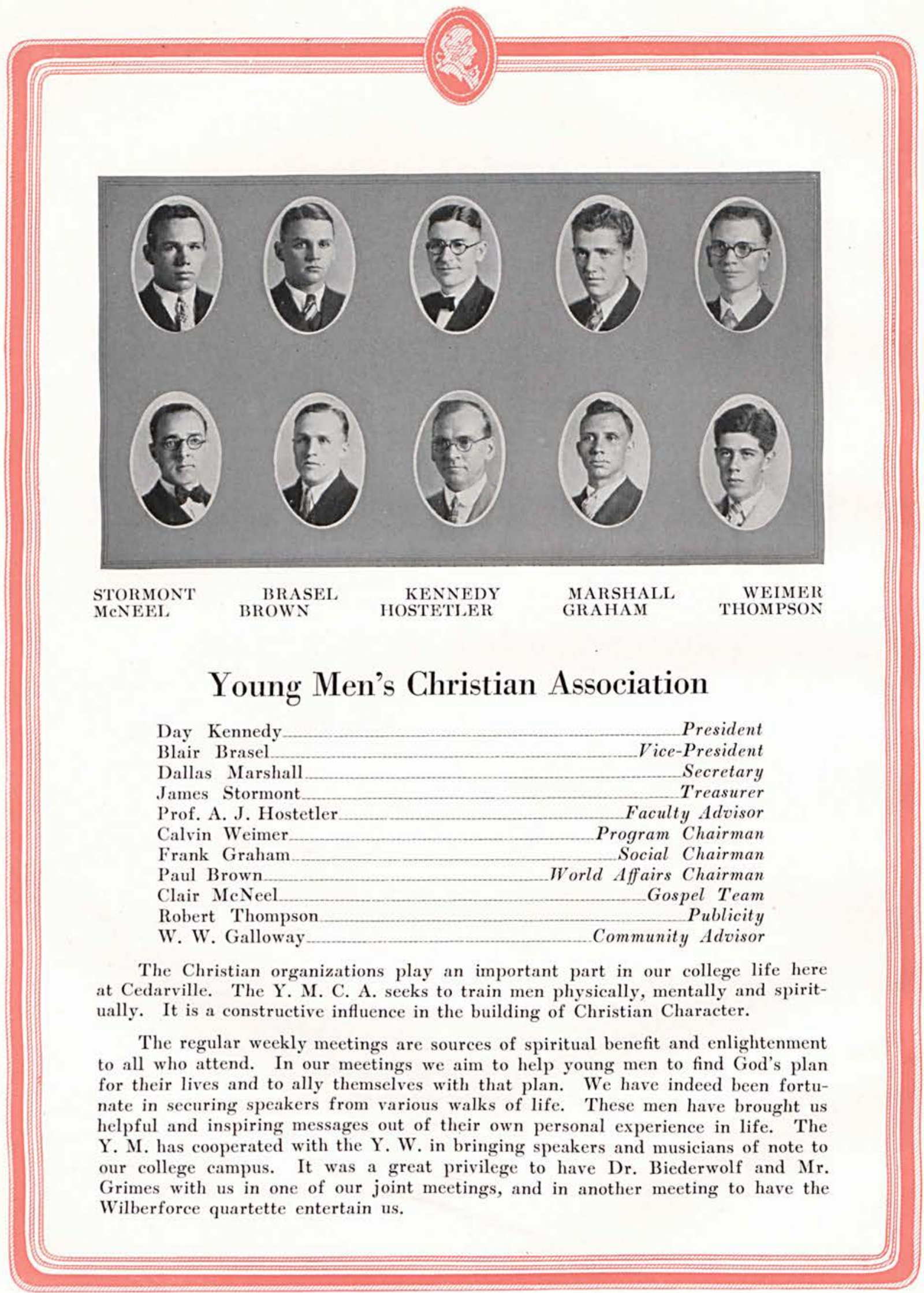

Page Eighty-six 


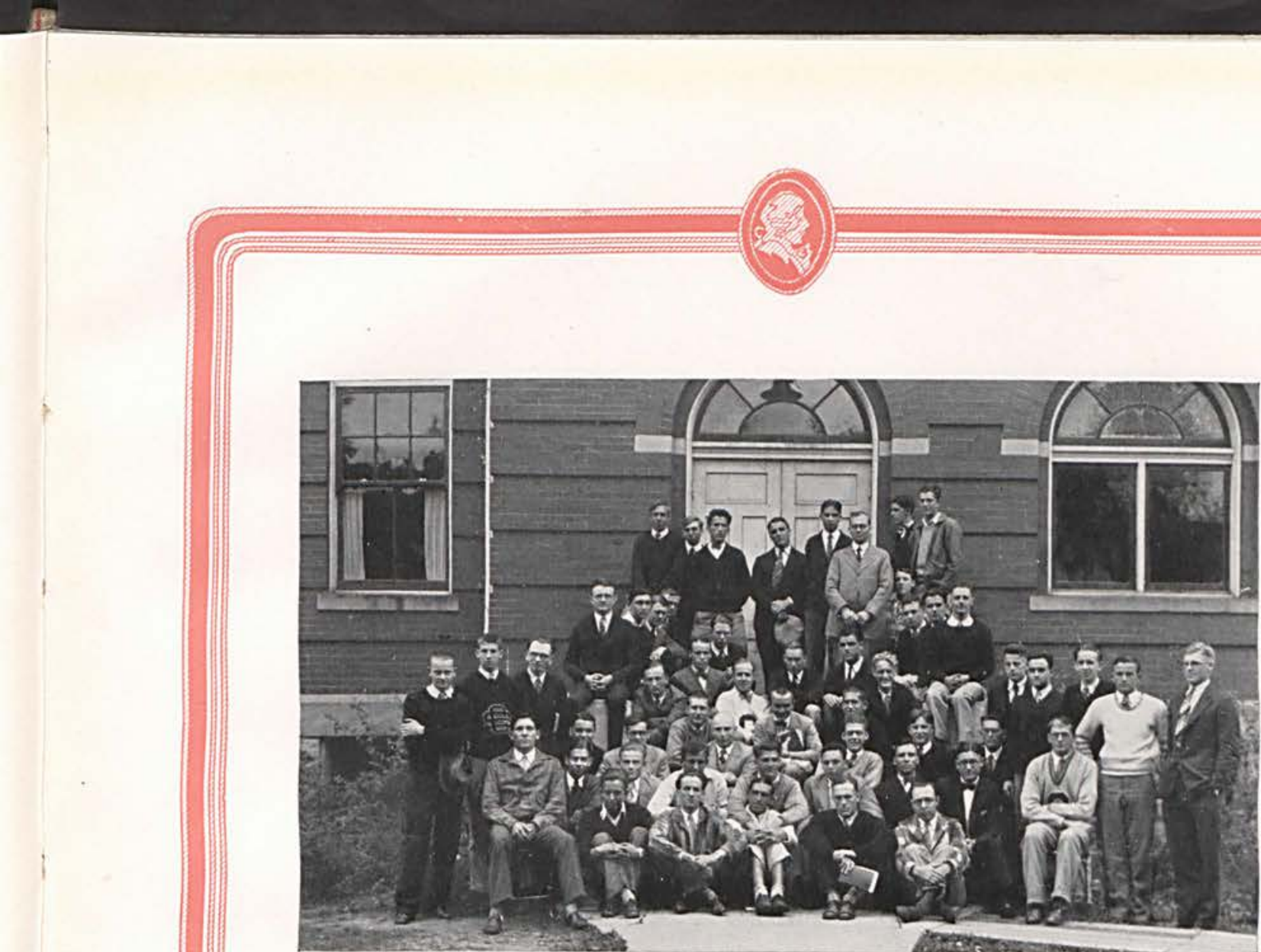

Two of our members attended the Lake Geneva Y. M. C. A. Conference which was held last June. This was made possible through the kindness of Mr. W. W. Galloway, the churches of Cedarville, and other friends of the organization. These delegates have tried to put into practice some of the good things they learned at the conference, in order that the will of Christ may be made more effective in our daily campus life.

The social activities have not been neglected in our program. We have had many good times together which have deepened the spirit of friendship. We shall long remember the Hallowe'en Party and other social affairs of the year in which the Christian organizations have taken a leading part.

One of the worthwhile accomplishments of our association this year was the College Minstrel which was presented March 28th, under the able direction of Mr. A. G. Duffey of South Charleston.

We desire to thank our many friends who have helped in any way to make the year a success in our Y. M. work.

D. $\mathrm{K}$. 


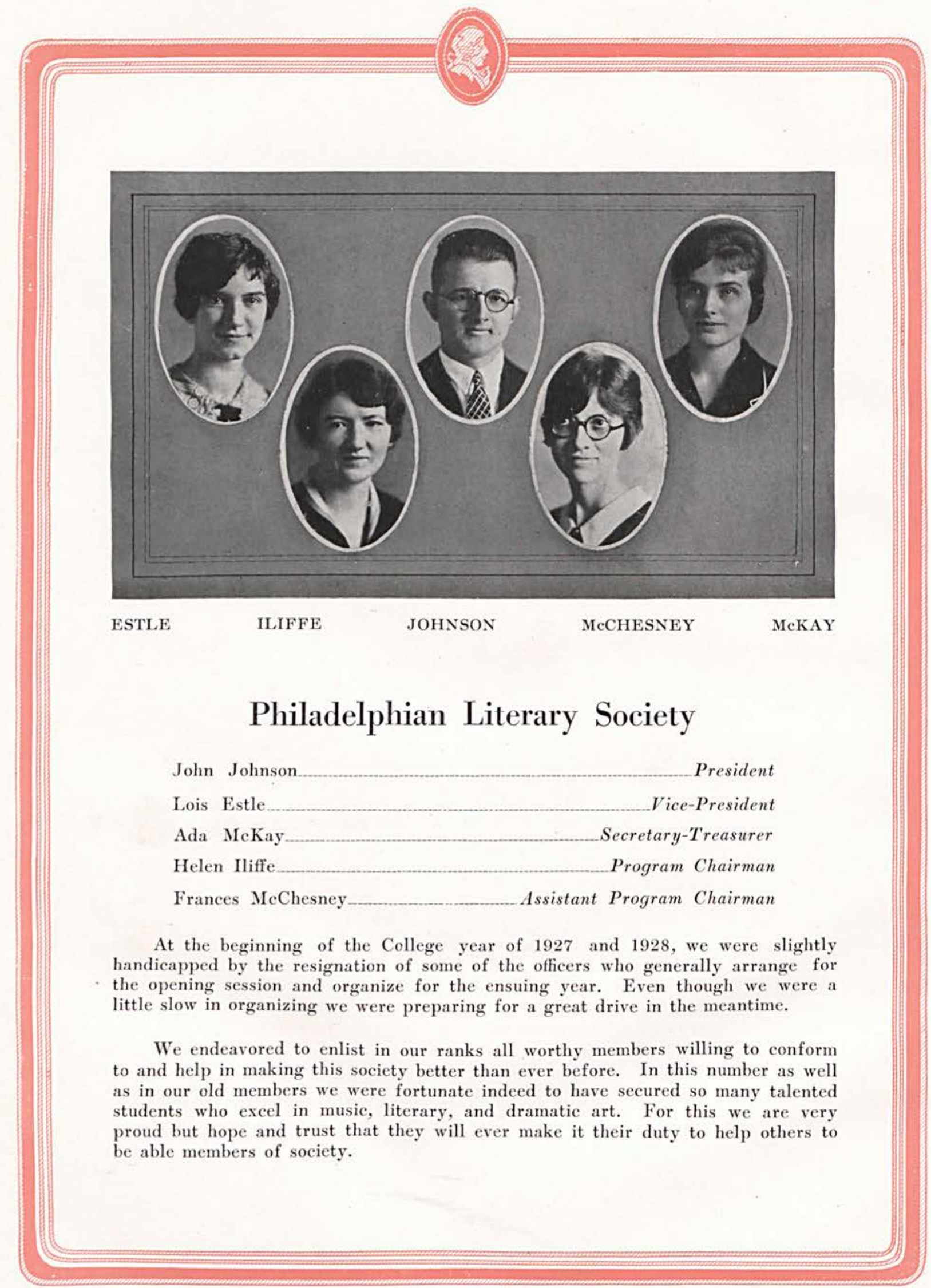

Page Eighty-eight 


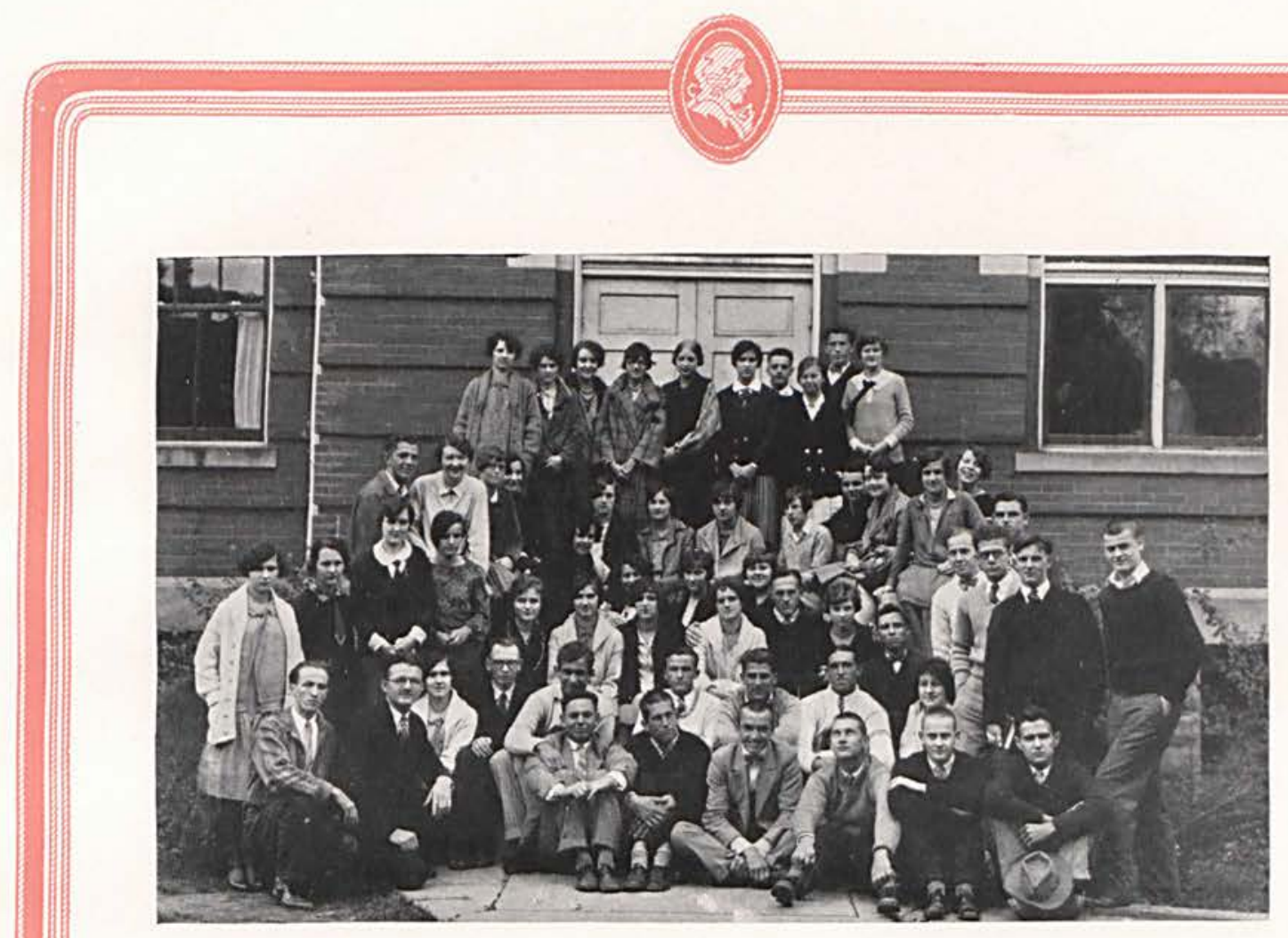

We hold our regular meetings bi-monthly and programs are logically arranged so that they may be appropriate for each meeting. They follow a course that is varied in content and form. This we do to develop the talent in the individuals and at the same time be very instructive and entertaining to all concerned. It is evident that this has embodied the eager efforts of everyone; that our profound purpose be to strive for quality in everything attempted.

It has been our aim to cultivate the highest ideals, to elevate the cultural standard and to instill in our members a desire for the best in musical and dramatic art. This we hope will ever remain not only a pleasant memory but a liking and craving for the best of everything.

All our members are prominent in the activities of the college, designating that a wonderful atmosphere prevails and a high standard maintained. From this we are confident that the cultural tone of all is moved toward noble ends. Thus the Philadelphians are not only builders but messengers; and may your genius, geniality, and ability be that which we prize. May it be our crowning glory to do that which will lead the way and be a light to others! -J. E. J. 


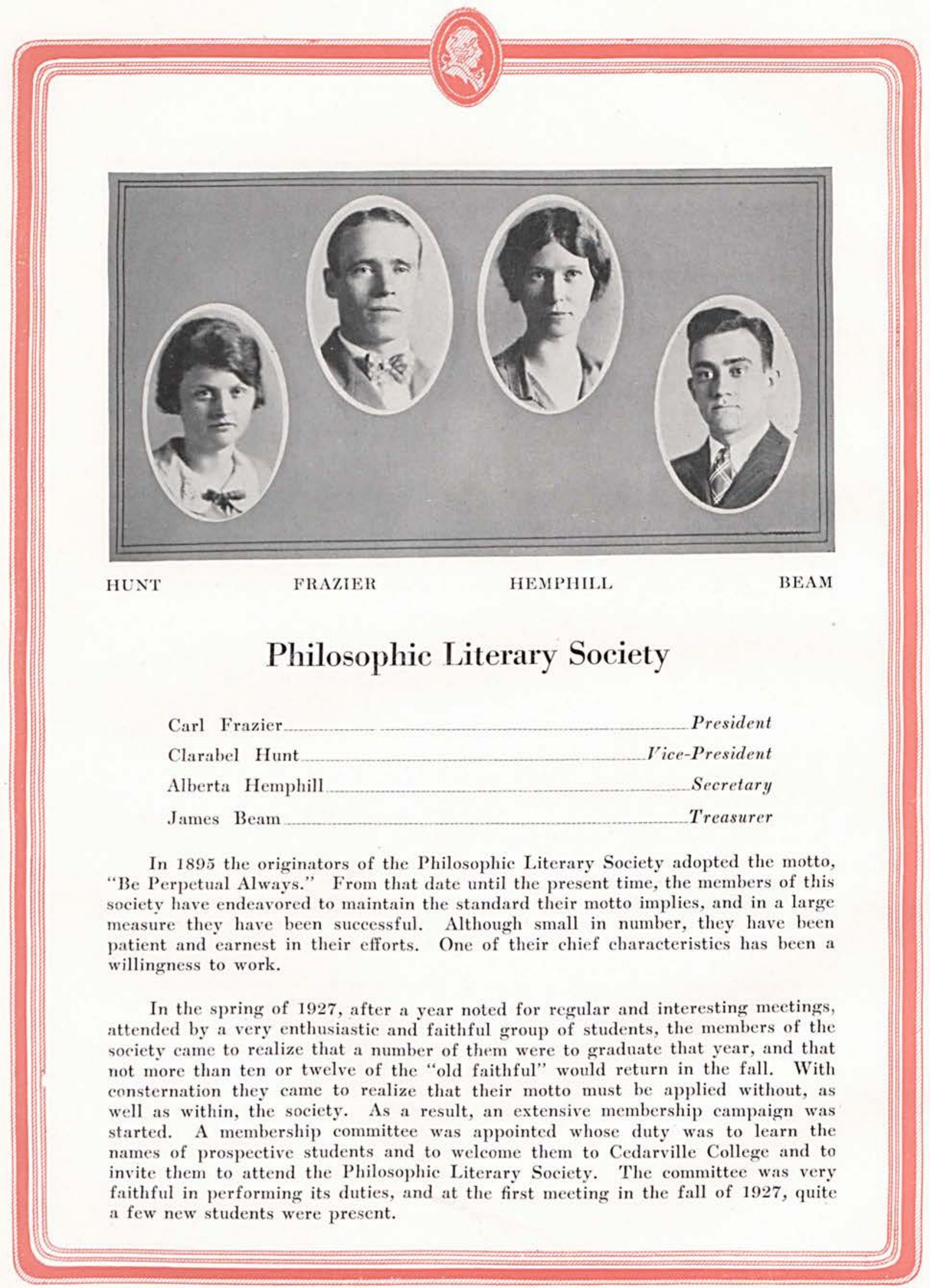

Pase Ninety 


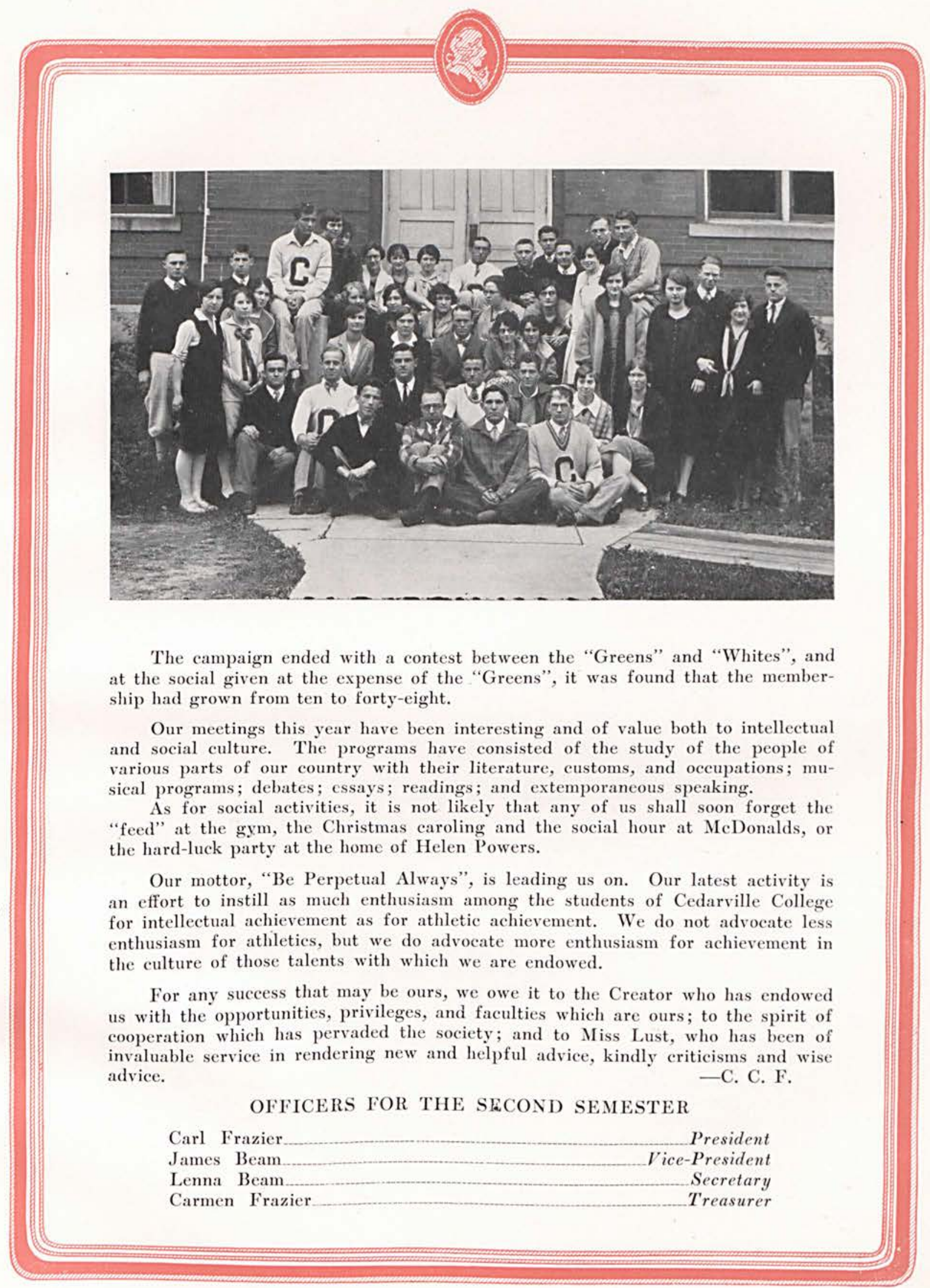

Page Ninety-one 


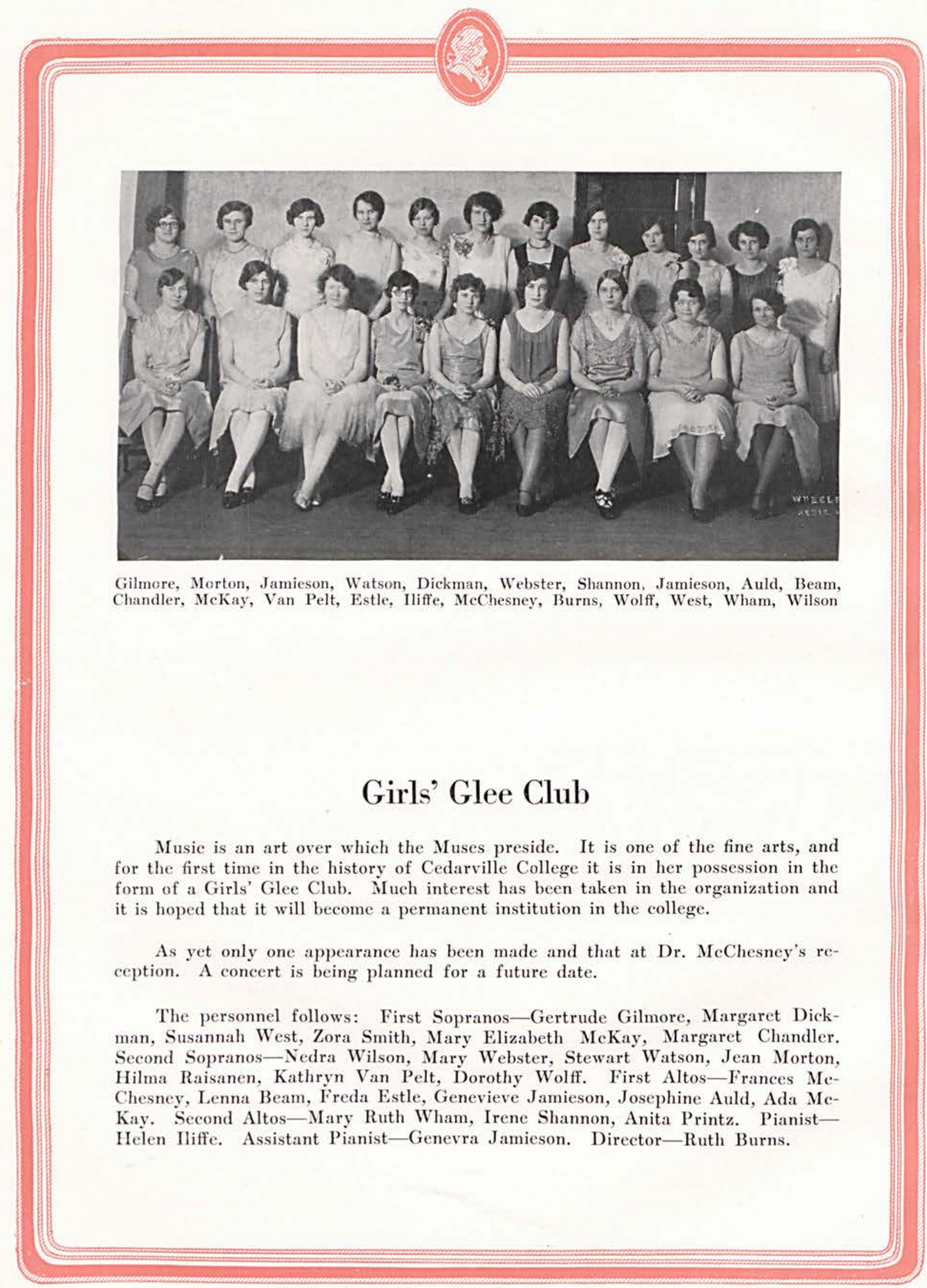

Page Ninety-two 


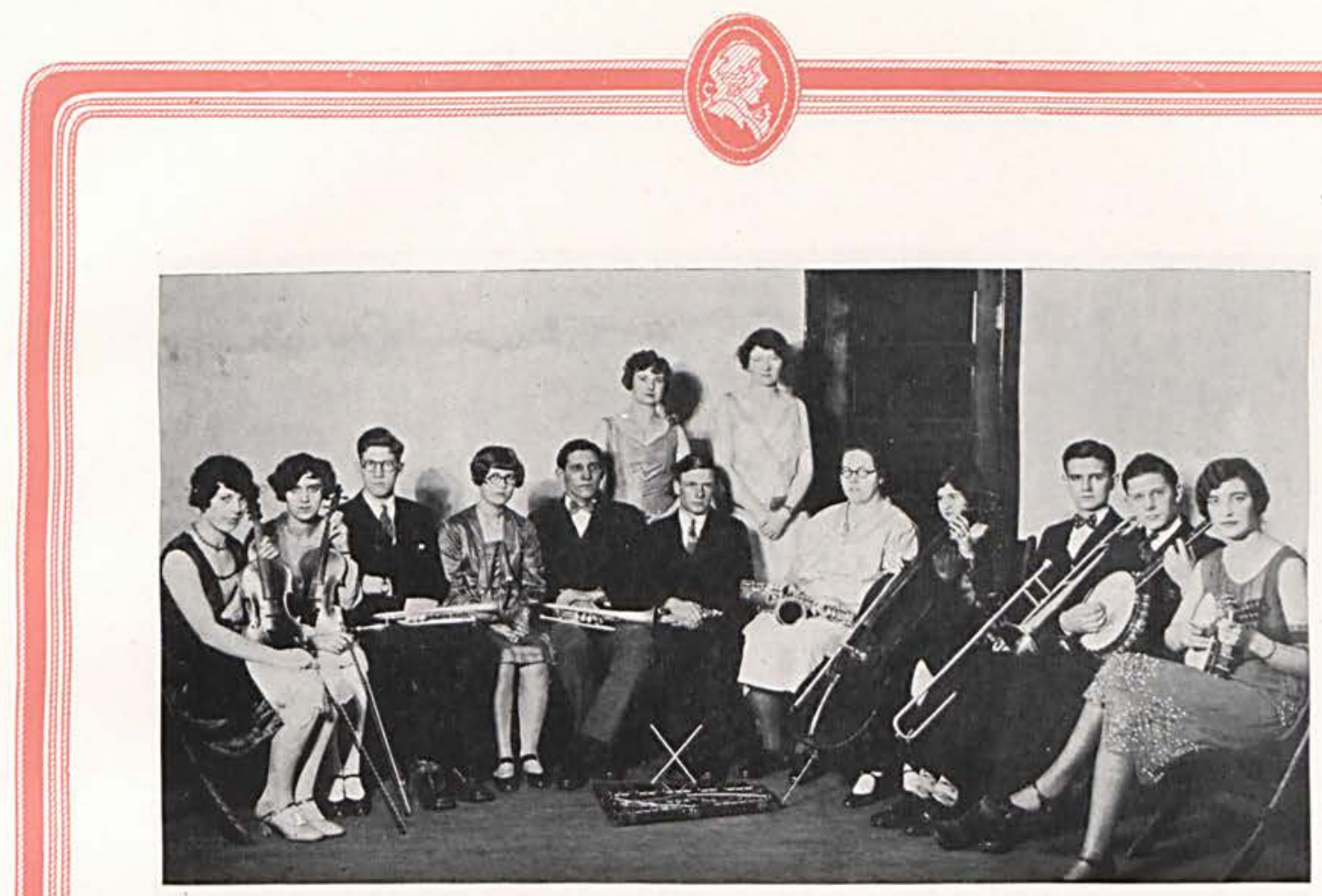

\section{College Orchestra}

It has been said that music hath charms to soothe; with this in mind the college orchestra was organized soon after the beginning of the first semester. Practice was adhered to faithfully and the debut was made at the Cedrus Play in November. Later appearances were at the Junior Play, the Home Coming Banquet, and the College Minstrel.

The members of the orchestra are as follows: First Violins-Irene Shannon, Viola Curry, Kenneth Conklin. Cello-Lillian Yaple. Mandolin-Dorothy Wolff. Banjo-Kenneth Ralston. Cornets-Robert Duffy, Irvin Harner, Myron MeDonald. Saxophones-Janis Carter, Kenneth Little, Vernon Hickman. BellsElizabeth Haydock. Trombones-James Lemon, A. C. Ewbank. Pianist-Helen Iliffe. Director-Ruth Burns. 


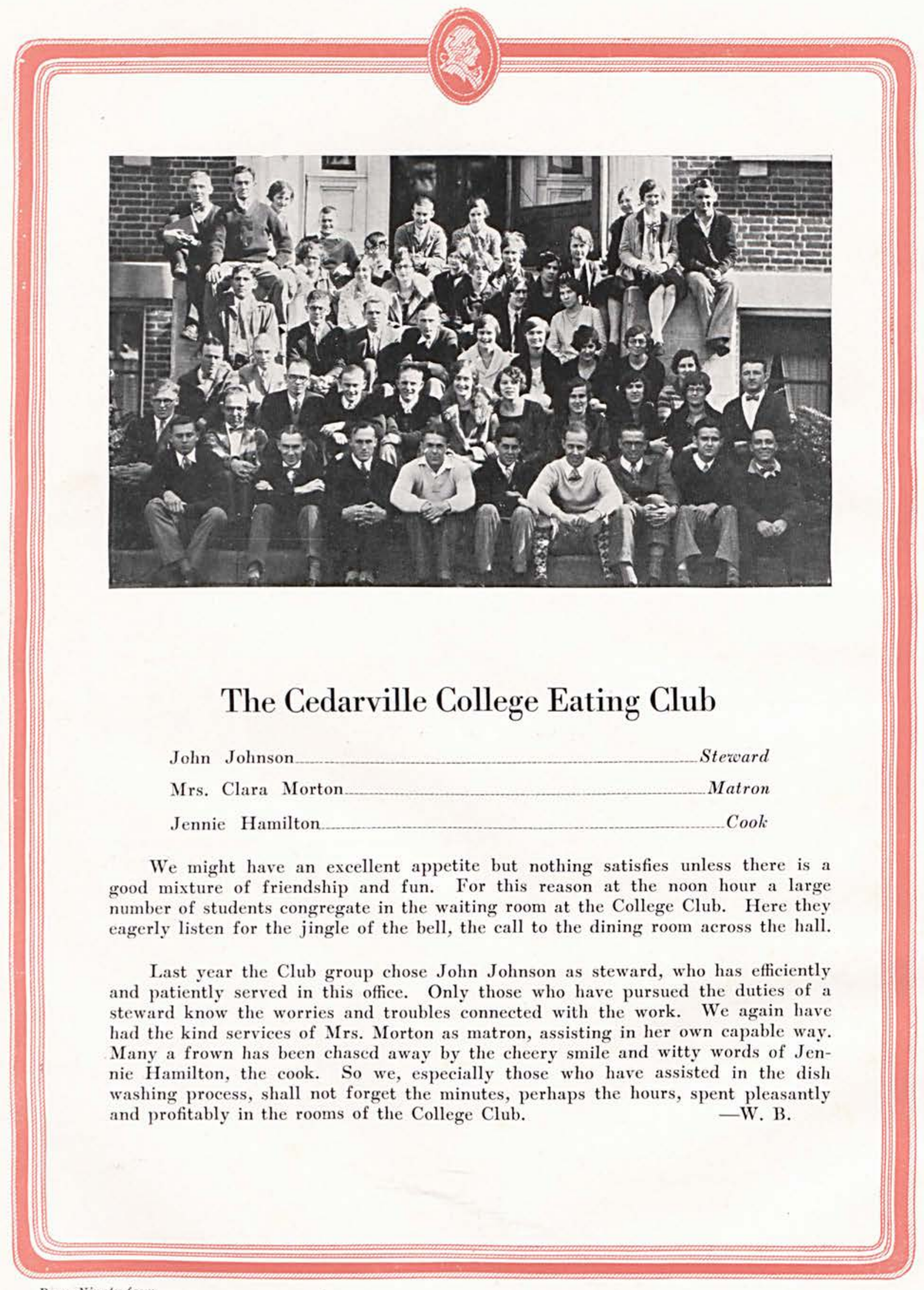

Page Ninety-four 


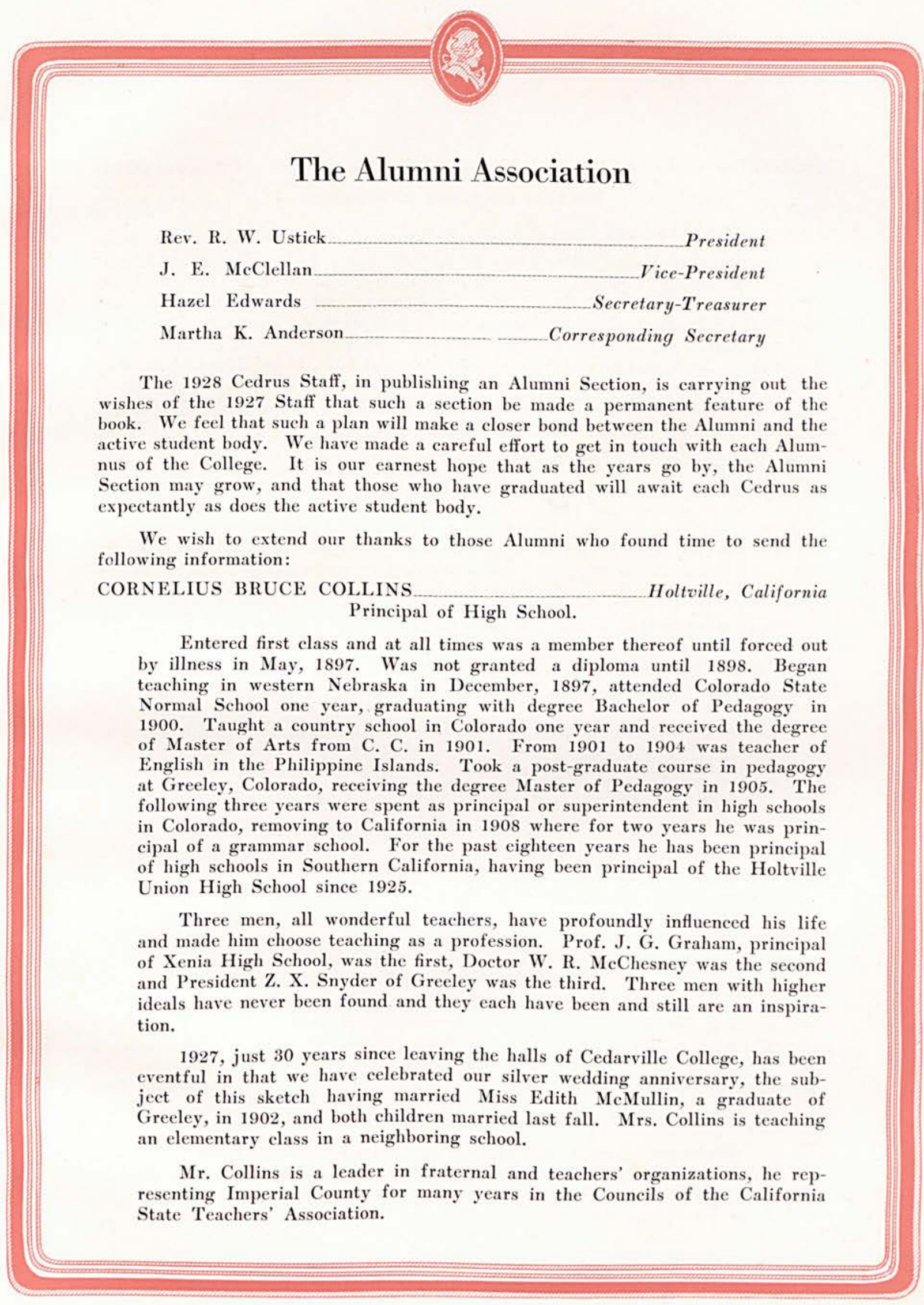


DOROTHY COLLINS Brooklyn, N. Y.

\section{Brooklyn Federation of Churches}

I've been thinking about our class of 1916, which was one of the large classes to graduate: Merle Rife at Tarkio; Ralph Elder, Knoxville College; Orland Ritchie, England (has a pastorate there); Thomas Whyte, Philadelphia, $\mathrm{Pa}$. These are our "divines". There are also several teachers, Carey Ritchie; William Hastings, Mildred Foster, and George Sieglar. David Bradfute is on the farm. Three of the girls are married, Ada Wallace, Mildred Crouse and Gladys Post; and three of us are not, Margaret Rife, Mary Bird and Dorothy Collins.

\section{RETURN}

You led me in those young untutored years Through day and night,

Brought hope and vision and dispelled my fears, My peerless light.

But in the maze of life I lost your gleam Being foolish-wise,

And on an alien and misguiding beam I set my eyes.

Now down these latter years my way I grope, And from afar

Return to thee, oh ultimate dear hope, $\mathrm{Oh}$, long lost star.

\section{Pastor of United Presbyterian Church}

Six years removed from one's Alma Mater makes you appreciate Cedarville all the more as the years go by; I must not recall my pranks, nor have I any great attainments to speak of; but having been Editor of Cedrus 1924, I can appreciate your efforts in 1928 . 

WILLARD BARLOW Wilmington, Ohio

Teacher in Kingman H. S.

I am always on the lookout for happenings and news of Cedarville Coll ge. Although I am out of college I will always be thinking of the good times and training that $I$ received there.

DOROTHY LACKEY

Xenia, Ohio

Teaching is interesting, but I fear it would be like a sandwich without the filling, if it were not for the pleasant memories of the good times and the friendships made at "dear old C. C.".

KA'THRYN HUGHES

Cedarville, Ohis

Teacher in Cedarville Public Schools.

CARI. H. SHANKS Port William, Ohio

Principal of High School.

ISABEL CLARKE West Middlesex, Penna.

MRS. HUGH FRASER (nee Ruth Burbick) Wellsville, Ohio

LOIS GRACE BAUGHN Yellow Springs, Ohio Teacher in Junior High.

Always interested in old C. C.

And to it I will always obedient be,

A splendid place for knowledge

Is our dear old Cedarville College.

MAE MCKAY

Kingman, Ohio

Teacher in High School.

"Cedarville misses Mae: We wonder if Mae misses Cedarville”.

MARTHA DEAN Cedarville, Ohio

Professor in Cedarville College.

"How lucky to still be at C. C.".

So they say. Yes, but-gone are the irresponsible days of breakfast picnics, class feeds, hikes and parties. I like to be a teacher but I'd rather be a student again. 
RALPH BAKER

Dayton, Ohio

N. C. R. Plant.

MARY BEAM

Teacher in High School.

EIIZABE'TH CRESWELL

Dayton, Ohis

Mart Tea Room

LAWRENCE DOUTHET'T

Hamilton, Ohio

Levy Shoe Co.

PAUL ORR

MeConnellsville, Ohio Teacher and Coach in High School.

JOHN ROCKHOLD Dayton, Ohis Teacher of Physical Education.

ROBERT TURNBULL Columbus, Ohio O. S. U.

HAROLD HUSTON Urbana, Ohio Teacher in High School.

WILLIAM SNELL Loveland, Ohio Business.

WARD CRESWELI Norwood, Cincinnati Mgr. Kroger Store.

LLOYD McCAMPBELL Cedarville, Ohio Farmer.

ELEANOR JOHNSON Teacher in Ross High School.

MARGUERITE SPRACKLIN Cedarville, Ohio

LORENA SHARPE Teacher in Junior High School.
LOIS MANOR Teacher in High School
Cedarville, Ohio riddletown, Ohio Bowersville, Ohio Selma, Ohio

MALCOLM TURNER Teacher and Coach in High School.

HARRIE'T KYLE Cedarville, Ohio

MARVIN WILLIAMS Superintendent of High School. Spring Valley, Ohio 


\section{WANT TO GO BACK}

I want to go back to old C. C., The best school in the land, And go to all the games again And shout Rah! Rah!

To Alma Mater we will pledge Our love and loyalty.

I want to go back, I gotta go back To old C. C.

I want to go back to old C. C.

That dear old Cedar town.

The College and the Opera House, And places of renown.

Where Father and Mother pay all the bills And leave the rest to me,

I want to go back, I gotta go back

To old C. C.

At Cedarville College,

We get our knowledge.

We slinga da ink, and pusha da pen along.

At Cedarville College,

We get our knowledge.

We slinga da ink and pusha da pen along.

We slinga da ink, da ink, da ink

And pusha da pen, da pen, da pen

We slinga da ink and pusha da pen along,

At Cedarville College,

We get our knowledge.

We slinga da ink and pusha da pen along. 


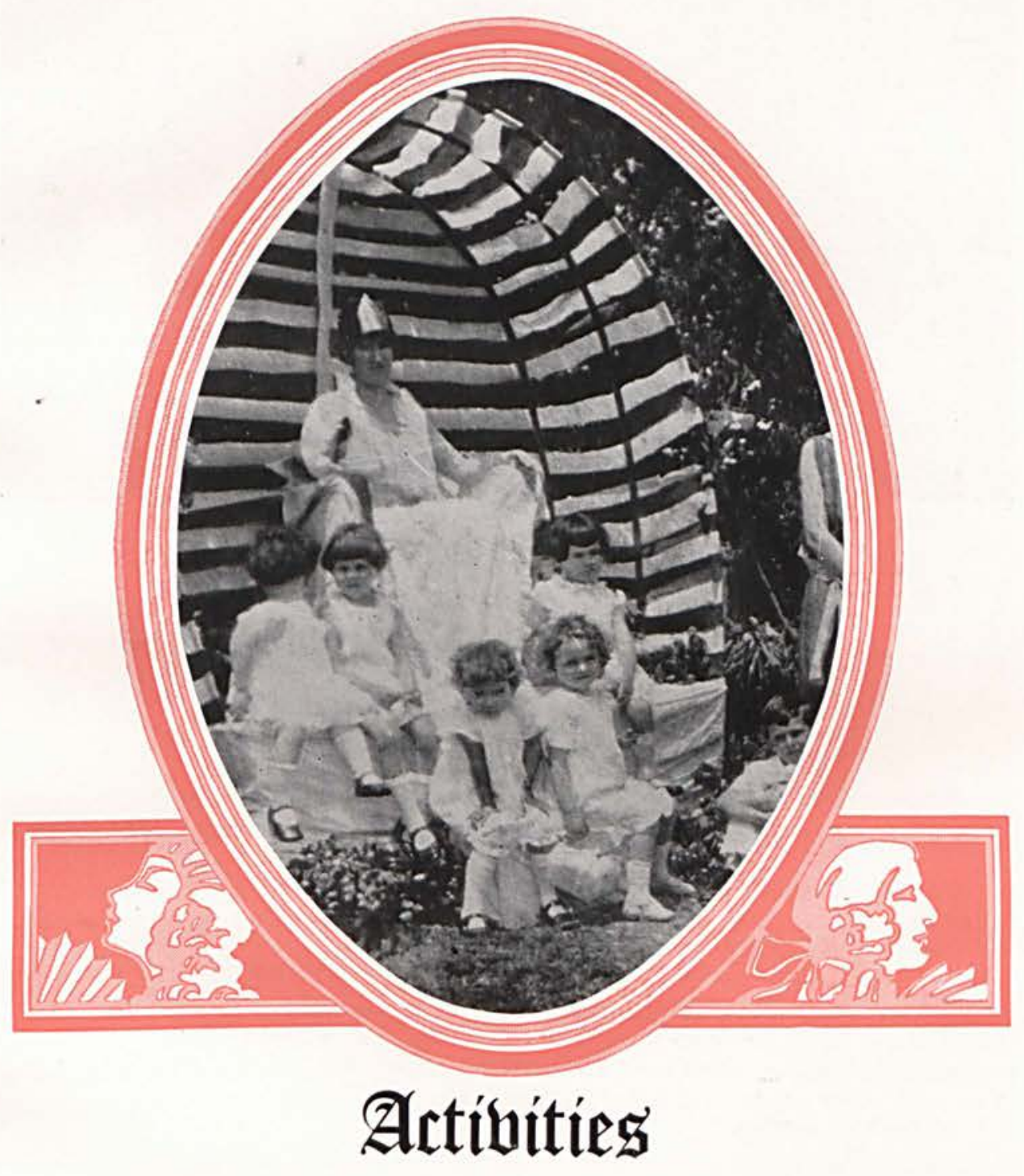




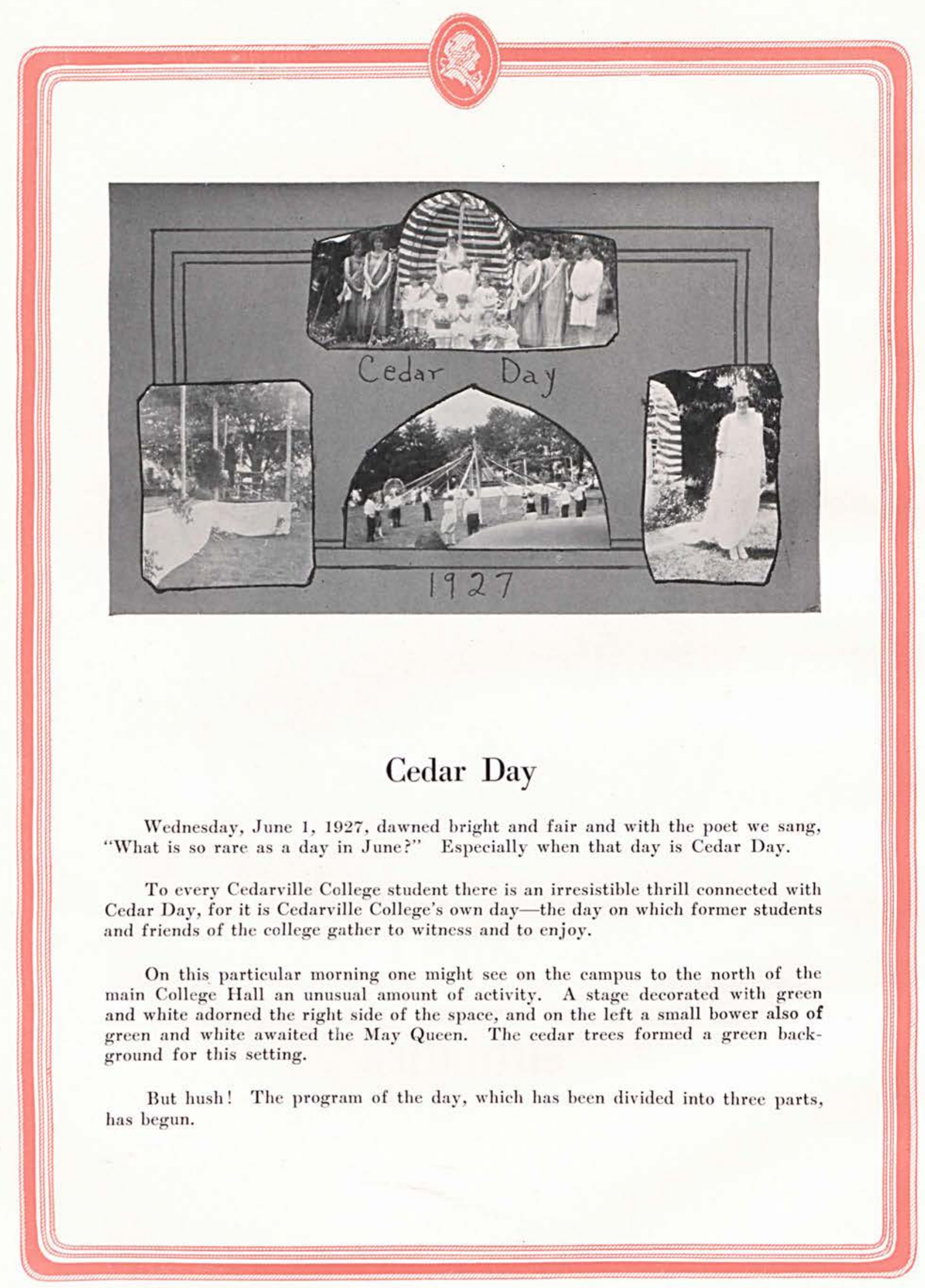

Page One Hundred and Two 



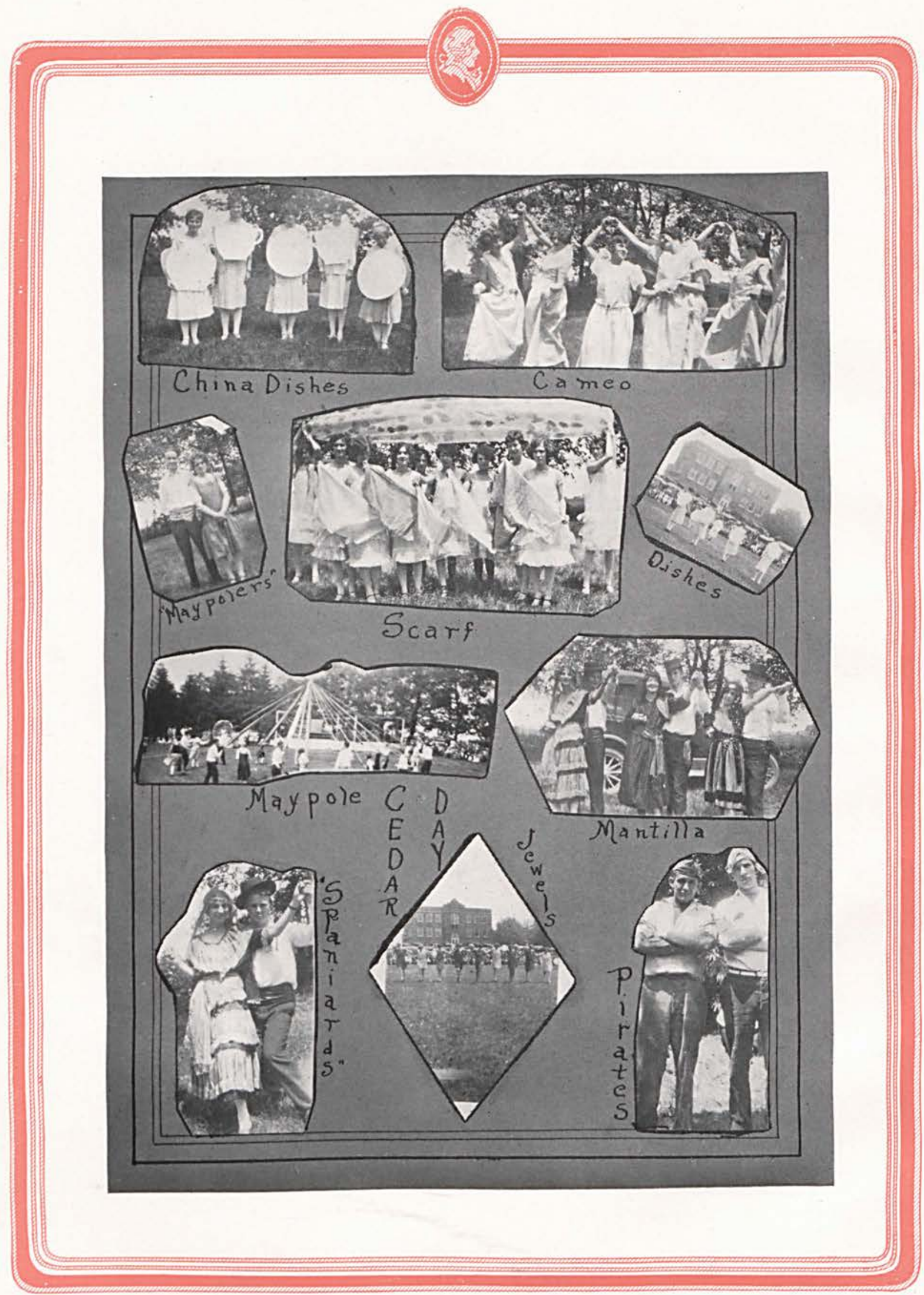

Page One Hundred and Four 


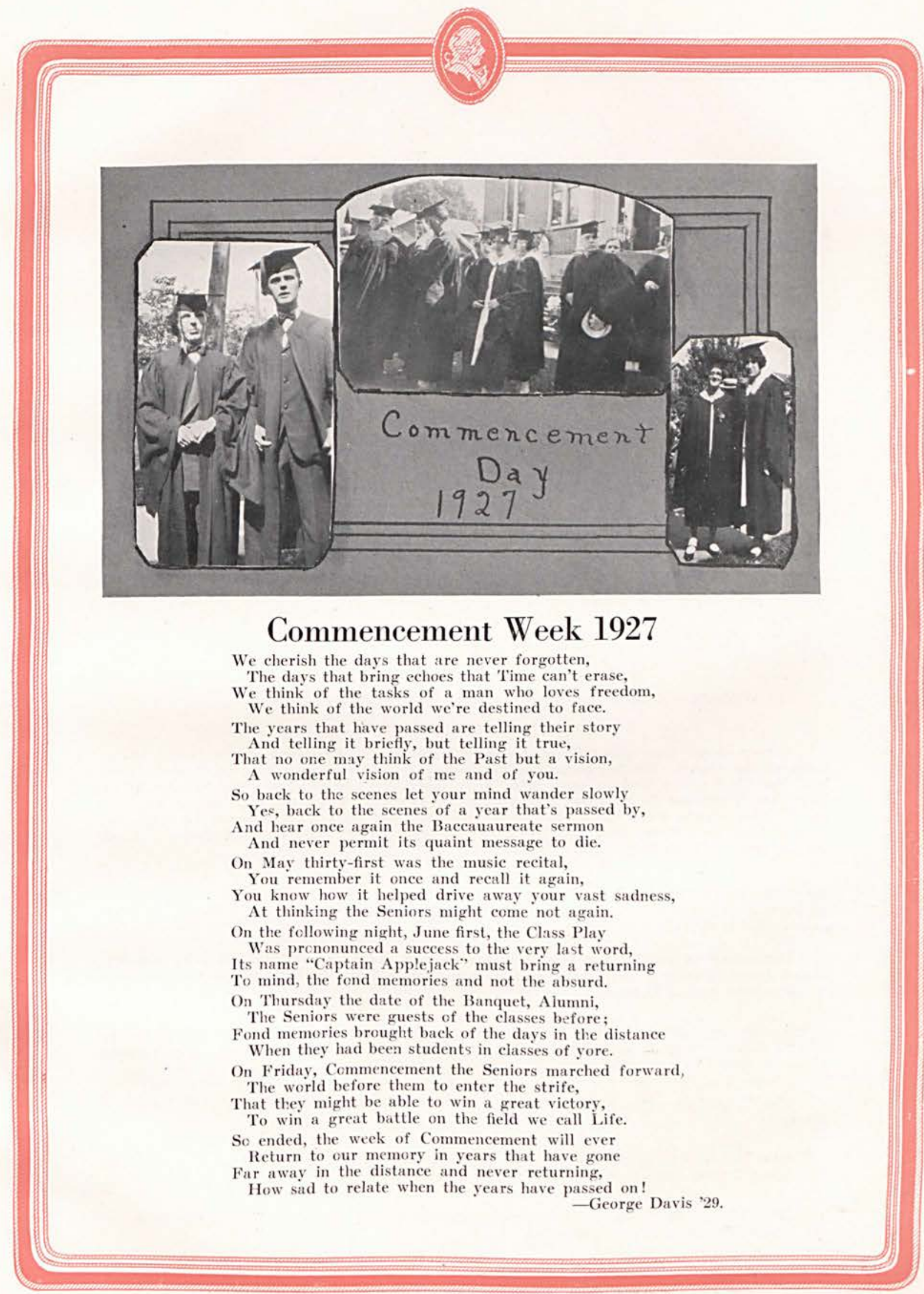

Page One Hundred and Five 


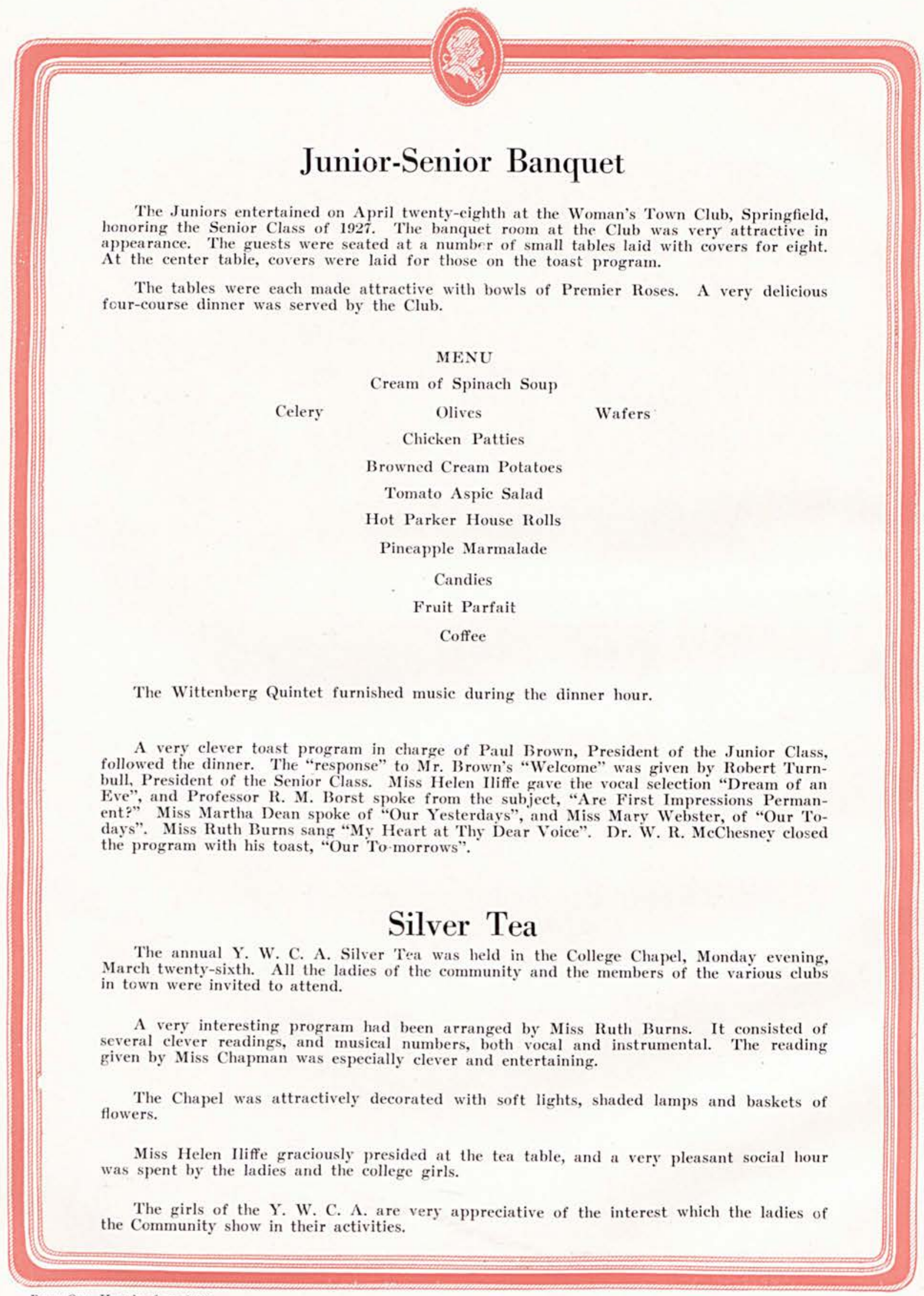

Page One Hundred and Six 


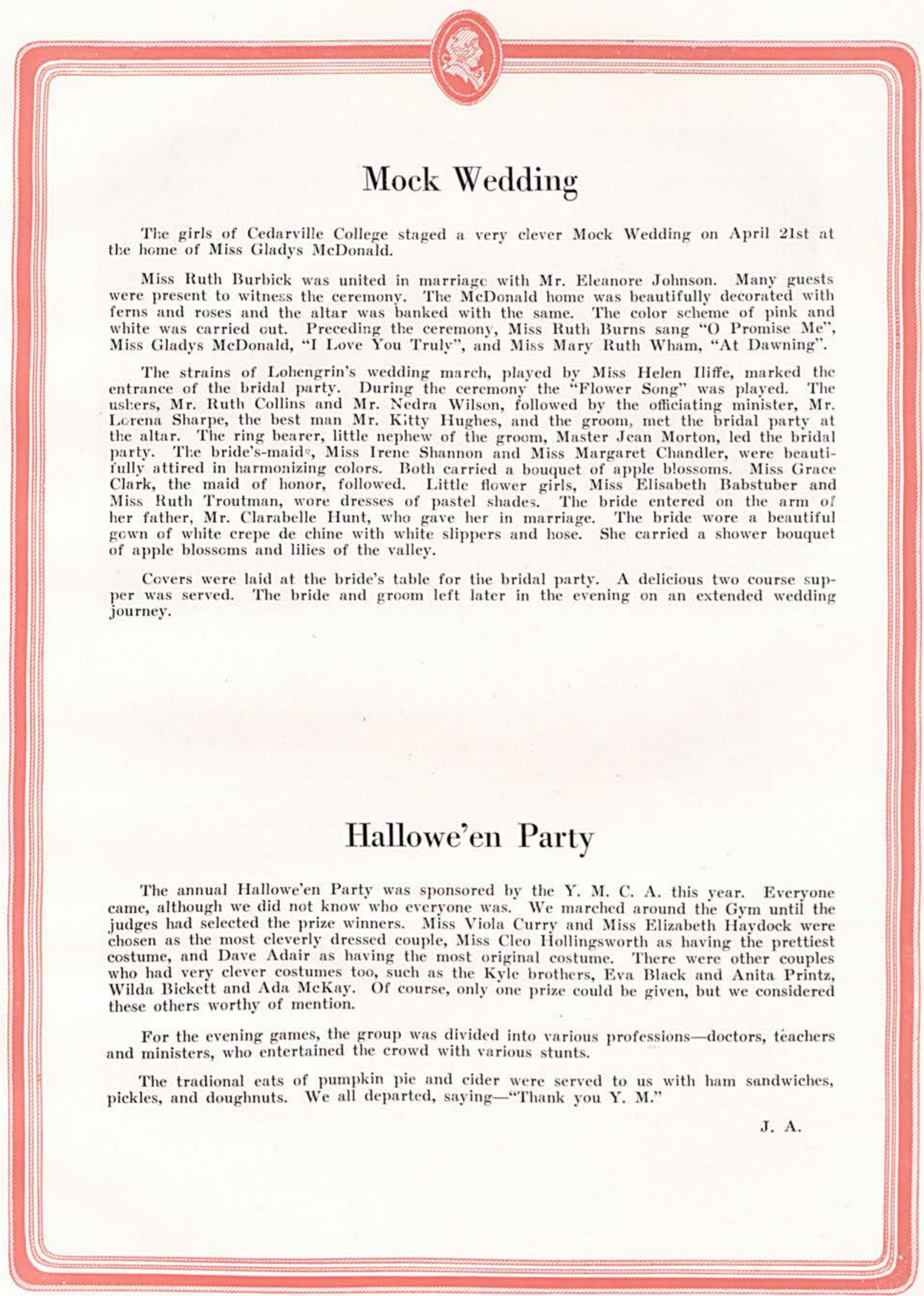

Page One Hundred and Seven 


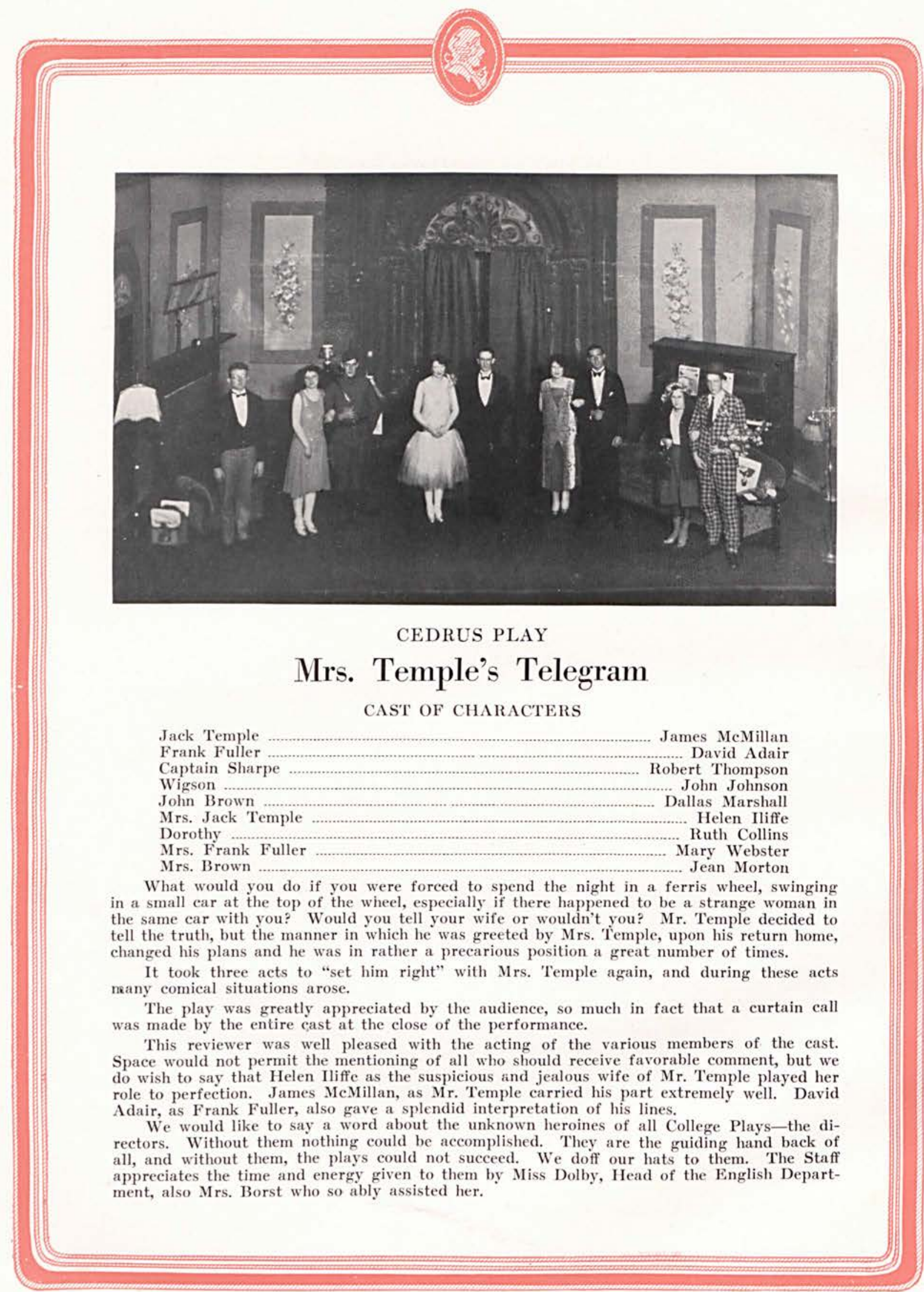

Page One Hundred and Eight 


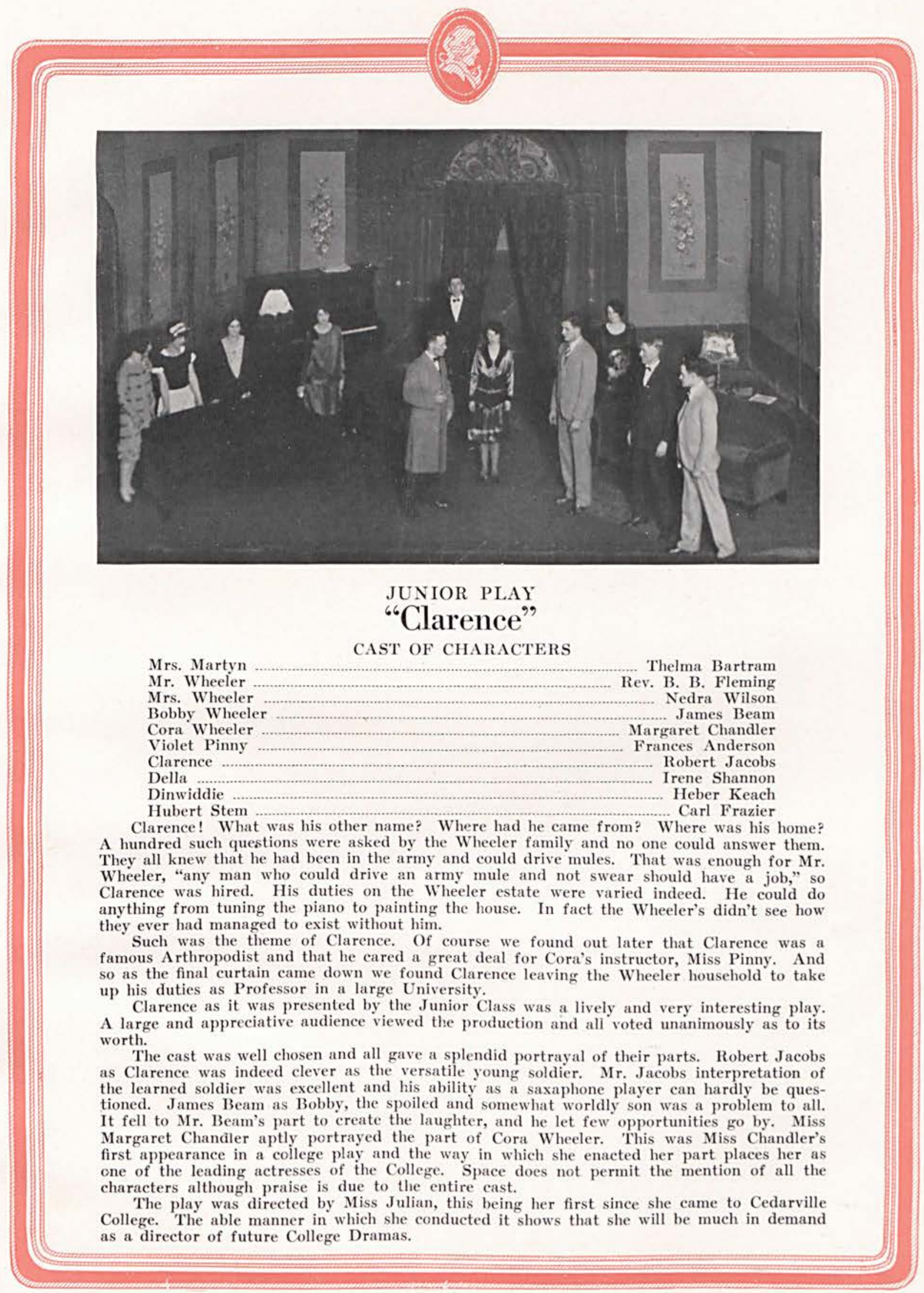

Page One Hundred and Nine 


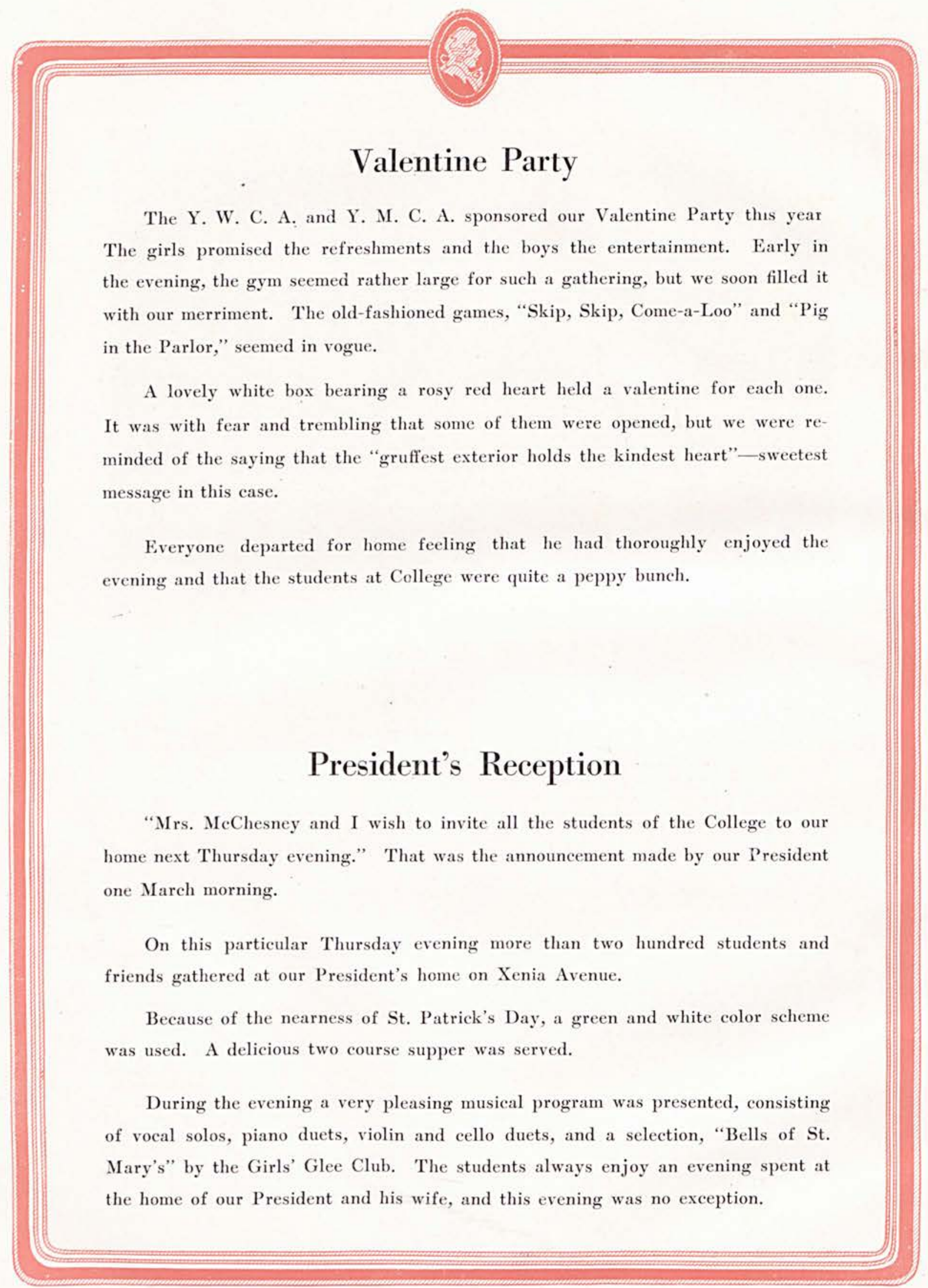

Page One Hundred and Ten 


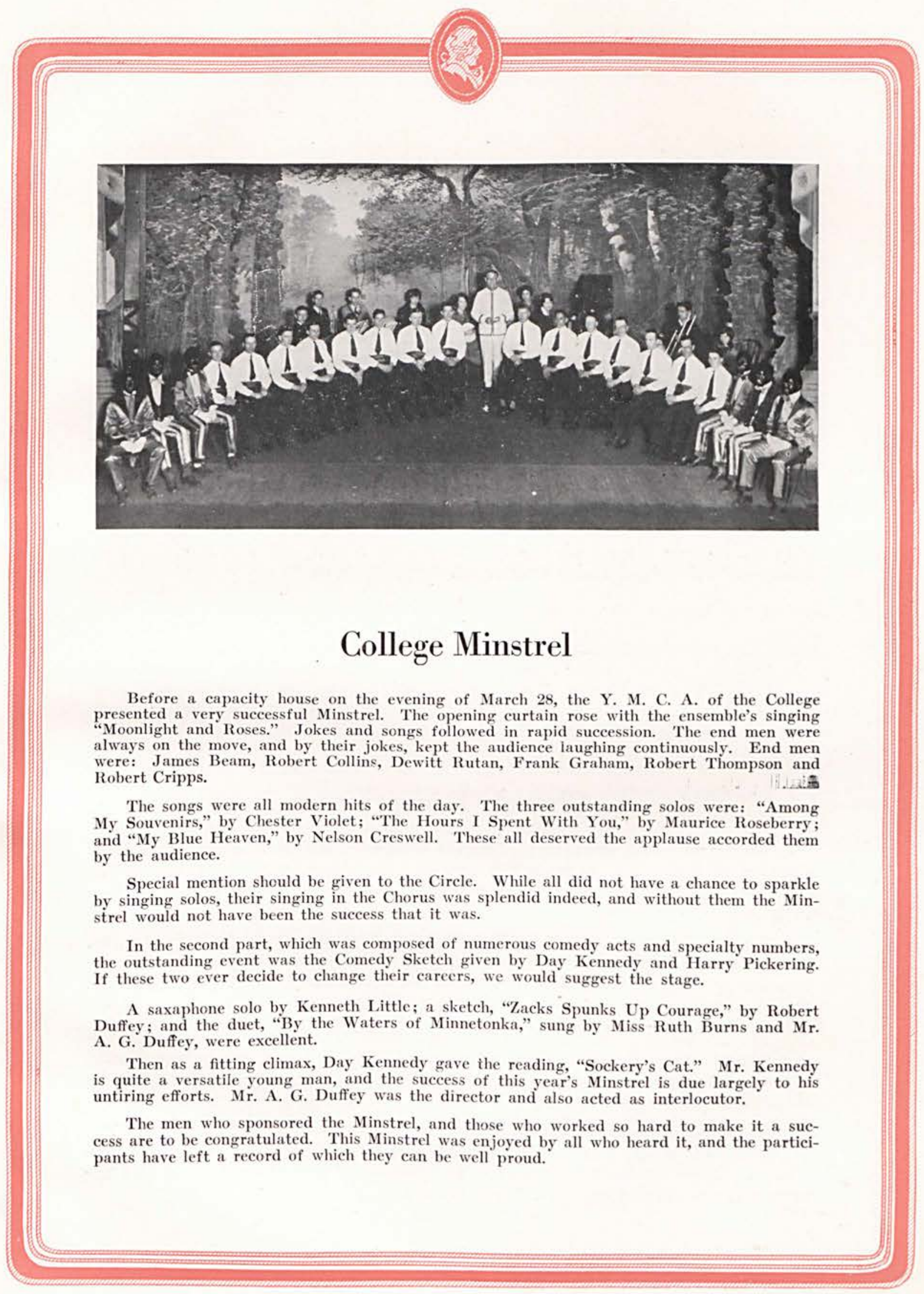

Page One Hundred and Eleven 


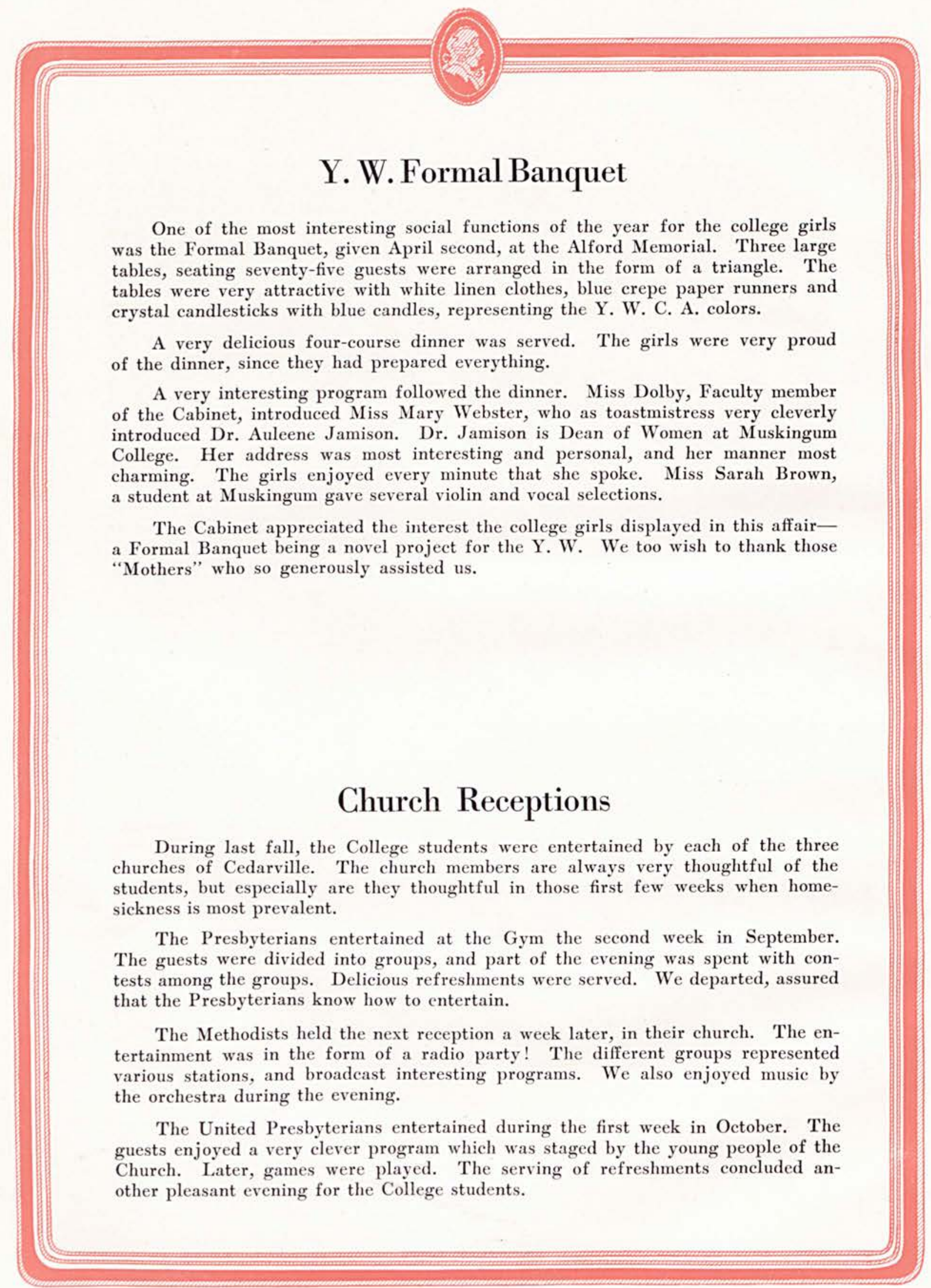

Page One Hundred and Twelve 


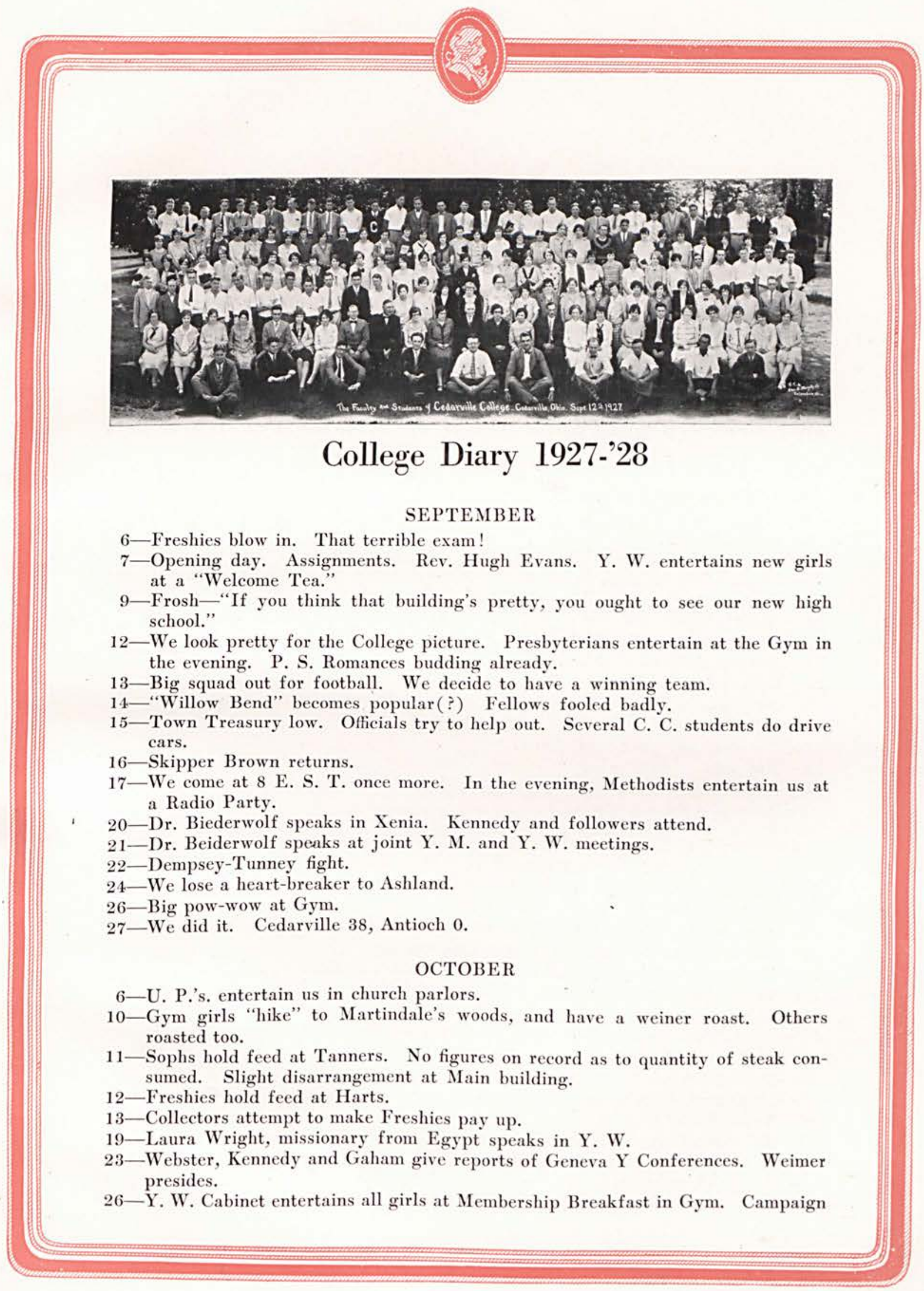

Page One Hundred and Thirteen 


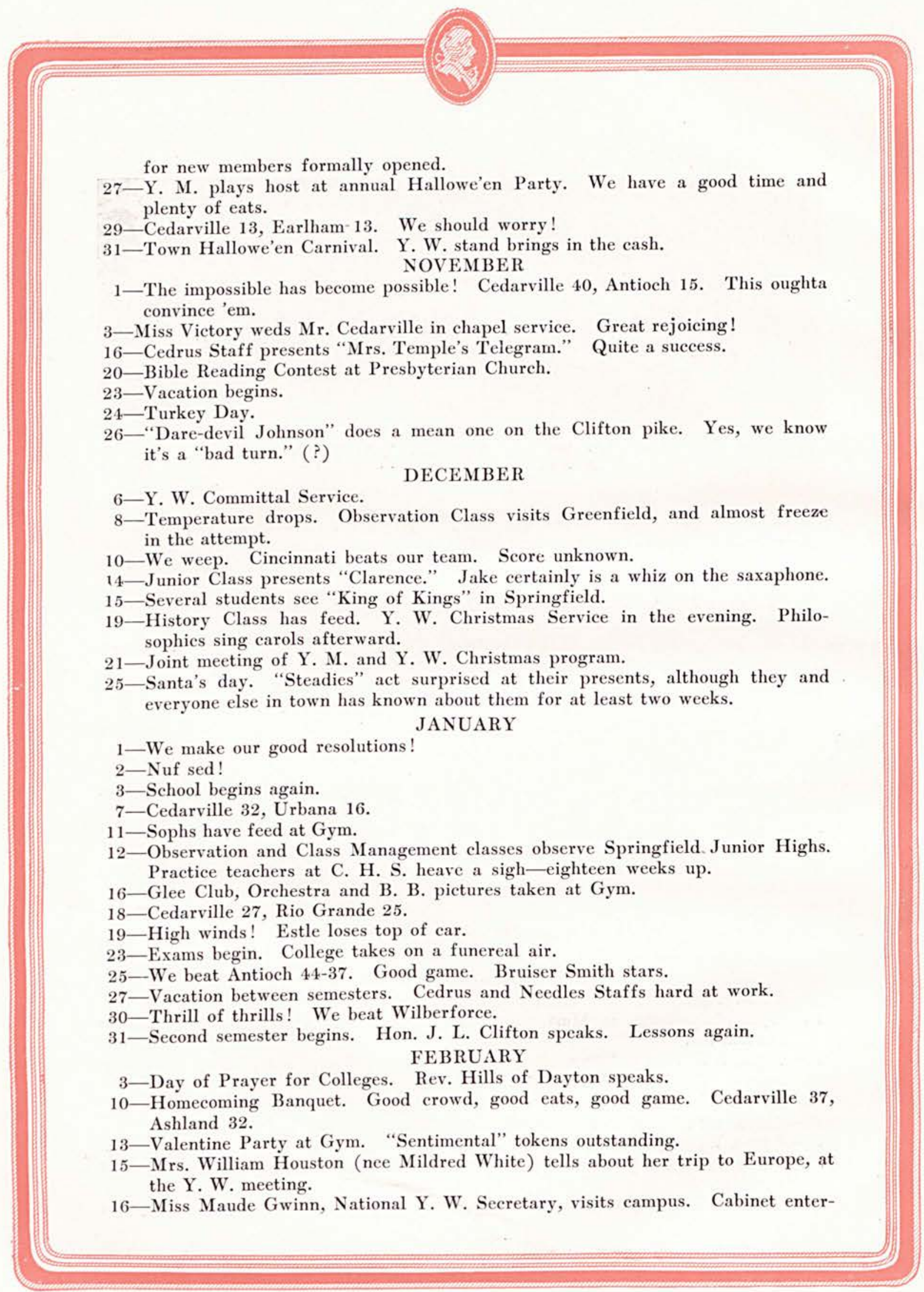

Paze One Hundred and Fourteen 


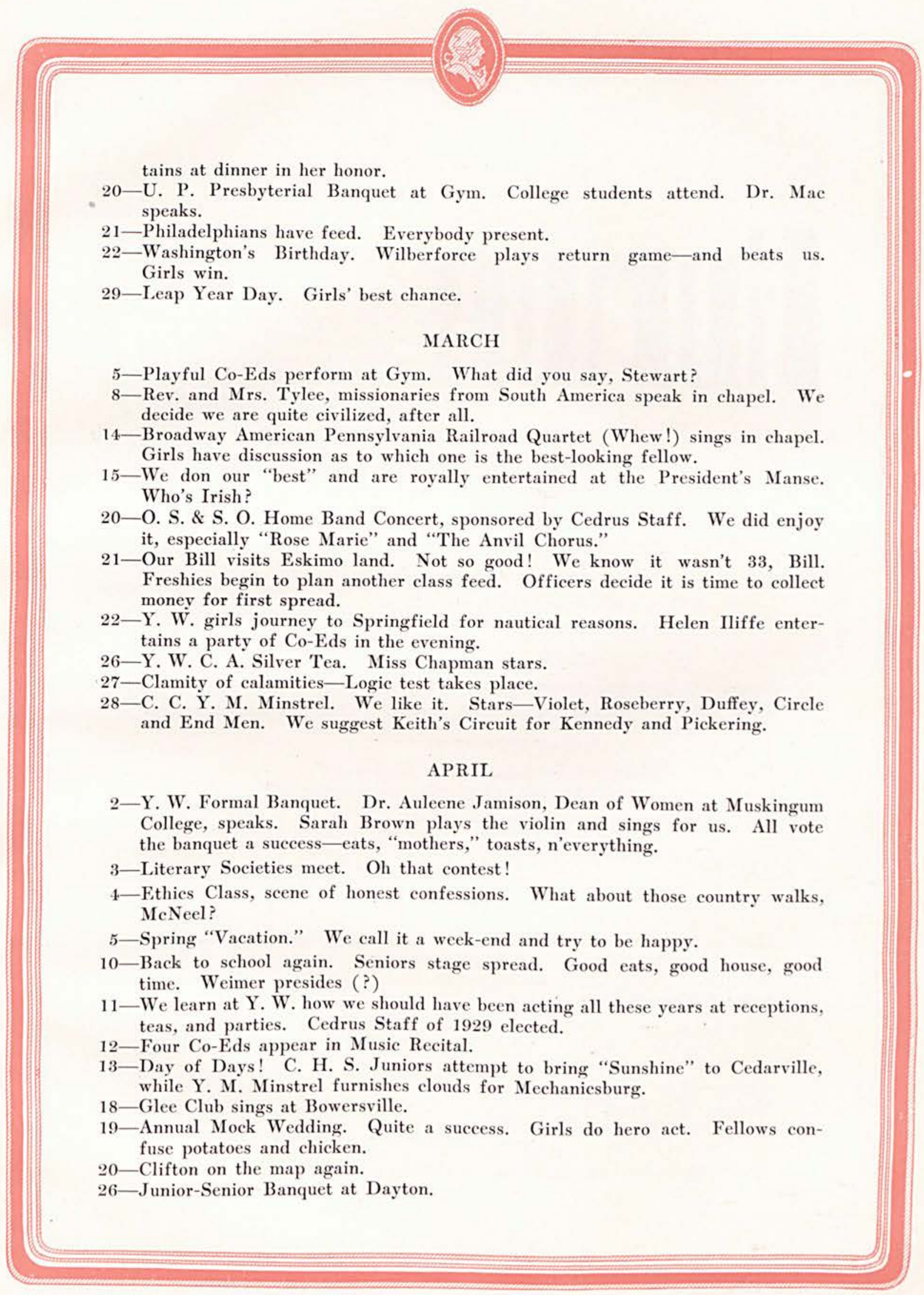

Page One Hundred and Fifteen 


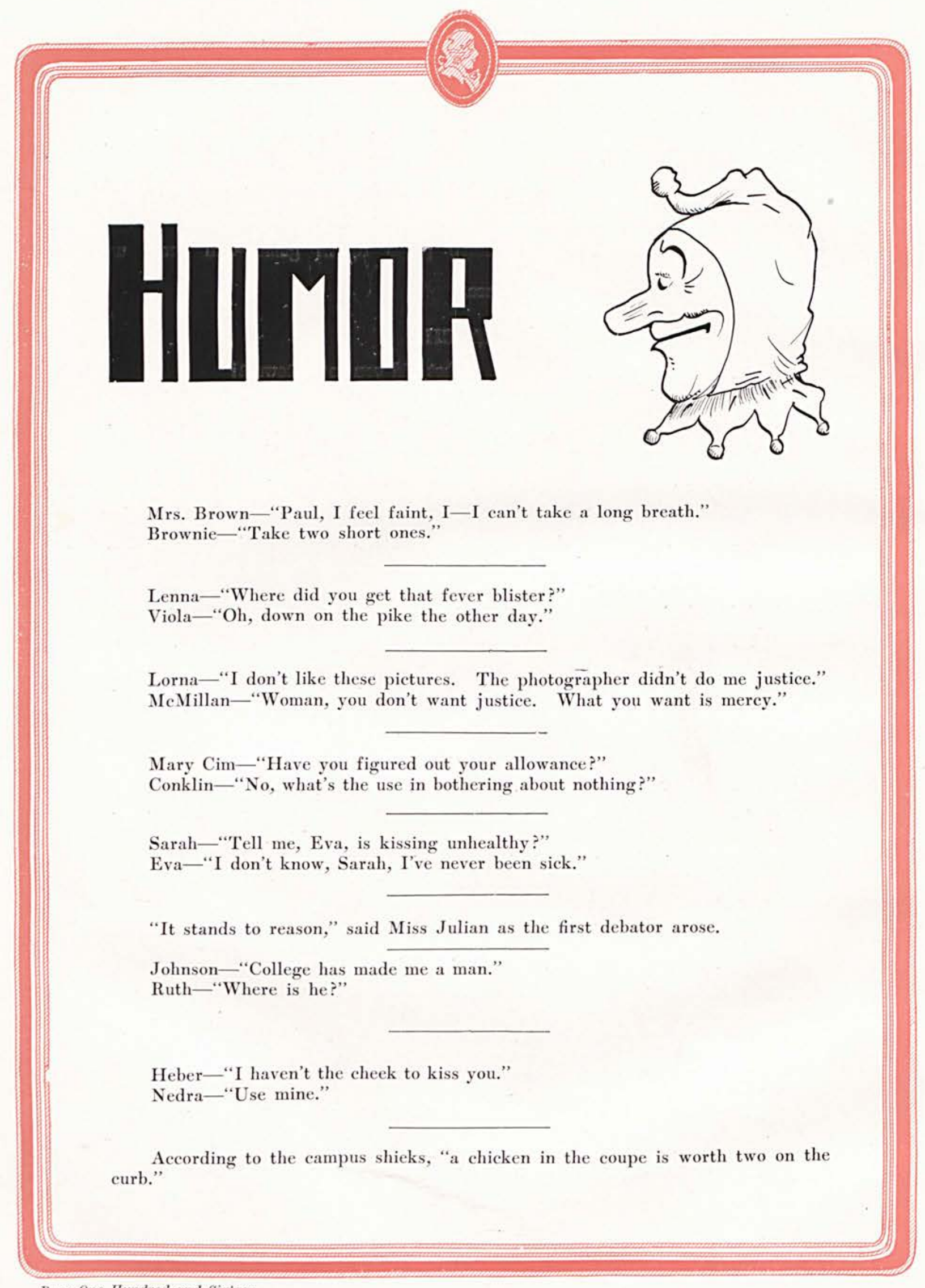

Page One Hundred and Sixteen 


\section{Our Advertisers}

We wish to express our appreciation to "Our Advertisers" for having seen fit to reserve space with us in our annual.

It is our hope that they will not have cause to regret having done so, and that they will profit by this advertising section.

\section{CEDARVILLE}

Cedarville Building and Loan

R. C. Ritneour

W. L. Clemens

Ralph Wolford

Blue Bird Tea Room

Home Clothing Co.

C. E. Masters

The Exchange Bank

Cedarville Lumber Co.

I. C. Davis

W. W. Trout

Cedarville Bakery

The Rexall Store

Miami Valley Creamery Co.

Richards Drugs

Hager Straw Board and Paper Co.

Cedarville College

Karl Bull

Robt. Birds and Sons Co.

\section{CANTON}

Canton Engraving Co.

\section{XENIA}

Adairs

Wheeler Studio

Anderson Flower Shop

MeCurren Brothers

Abe Hyman

Geyer Book Shop

Hy-Art

C. A. Weaver Co.

Valet Press Shop

L. S. Barnes and Co.

Auto Necessity Co.

Gallaway and Cherry

The Criterion

Hagler and Weaver

Geo. Dodds and Son's Granite Co.

Xenia Candy Kitchen

L. A. Wagner

\section{DAYTON}

Miami-Jacobs Business College

\section{SPRINGFIELD}

E. W. Fulmer Co.

Stanton Studio

Edward Wren Company 


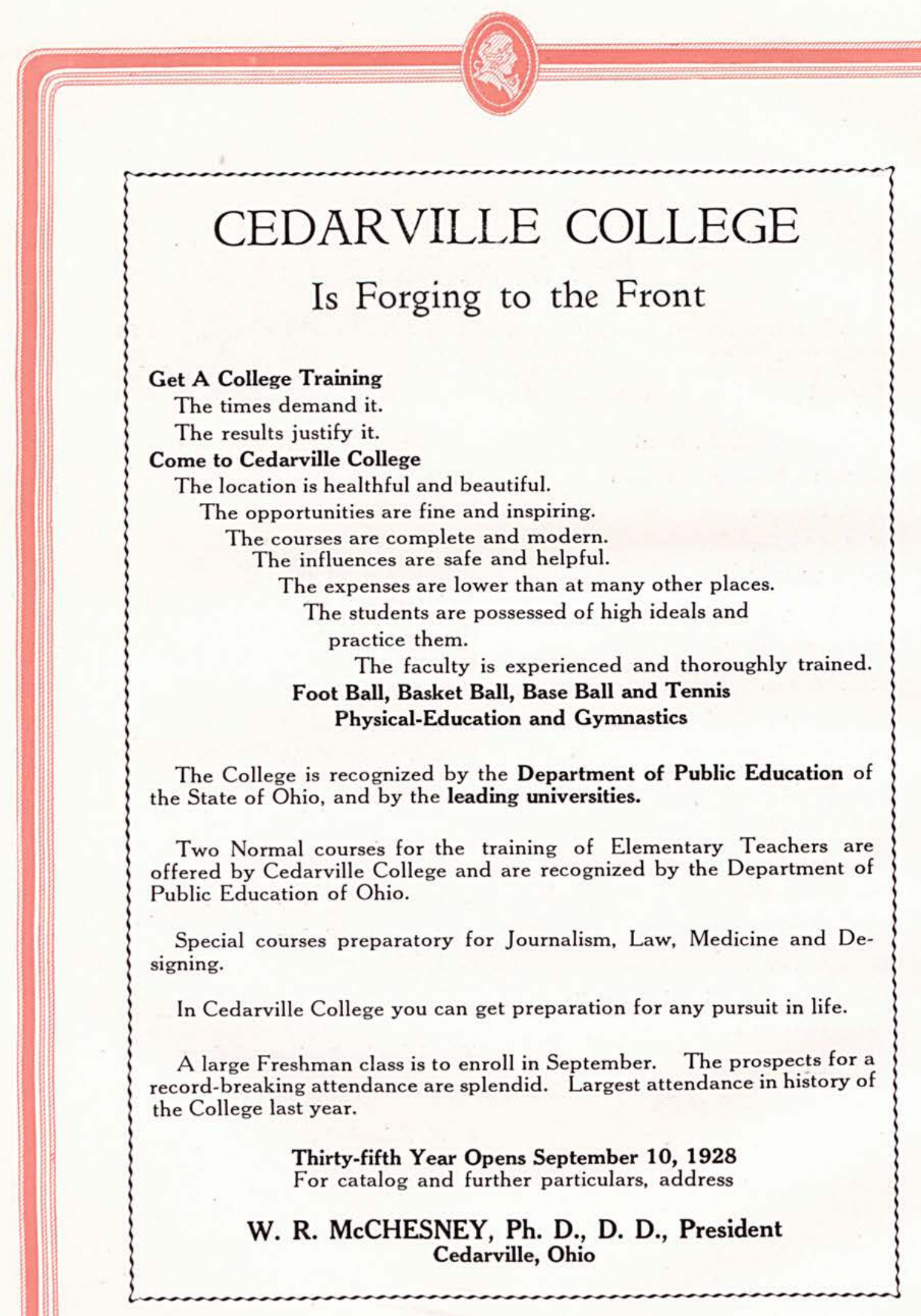

Page One Hundred and Eighteen 


\section{COLLEGE MEN-Your Clothes and You-}

You are audacious and your audacity asserts itself in your CLOTHES and your manner of wearing them.

CHARTER HOUSE CLOTHES take into account every manifestation of your audacity.

CHARTER HOUSE CLO'THES are made for you-and priced for you.

\section{THE C. A. WEAVER CO.}

Main St.

Xenia, Ohio

Opp. Court House

Dr. McChesney-"My boy there is a reason for everything."

Myron McDonald--"No sir, you forget women."

Evelyn-“Have you ever run amuck?"

Cripps-“Naw, I drive a Ford."

Ruth Burns-"Why the slicker?"

Ralston- "I'm so dumb I don't know enough to go in when it rains."

In relating a story about an escapade, one of the high school seniors said: "Every little sound made a noise."

"A few people fall in love, but the majority skid into it."

“All work and no pay makes Jack a school teacher."

Miss Julien-“What are your views on suicide?"

Keach- "I think it is too dangerous."

\section{COMPLETE DRY CLEANING SERVICE}

Clothes-Spotless and Odorless.

Carpets-Color restored like new.

Hats-Factory finish on all kinds-No chalky white finish on

Panamas but soft original finish.

\section{VALET PRESS SHOP}

33 S. Detroit St.

Carl M. Ervin, Prop.

Xenia Ohio

Page One Hundred and Nineteen 


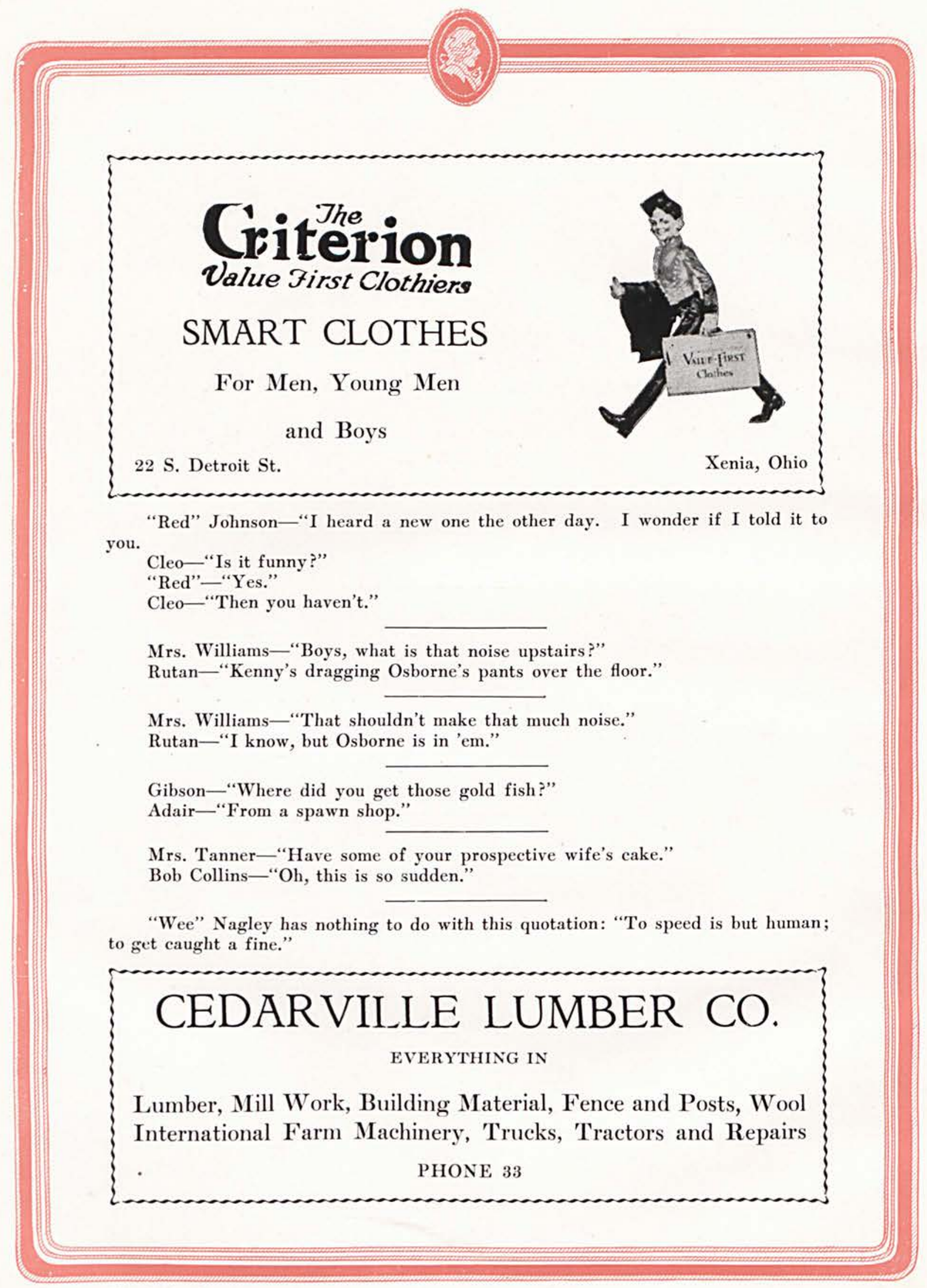

Page One Hundred and Tuenty 


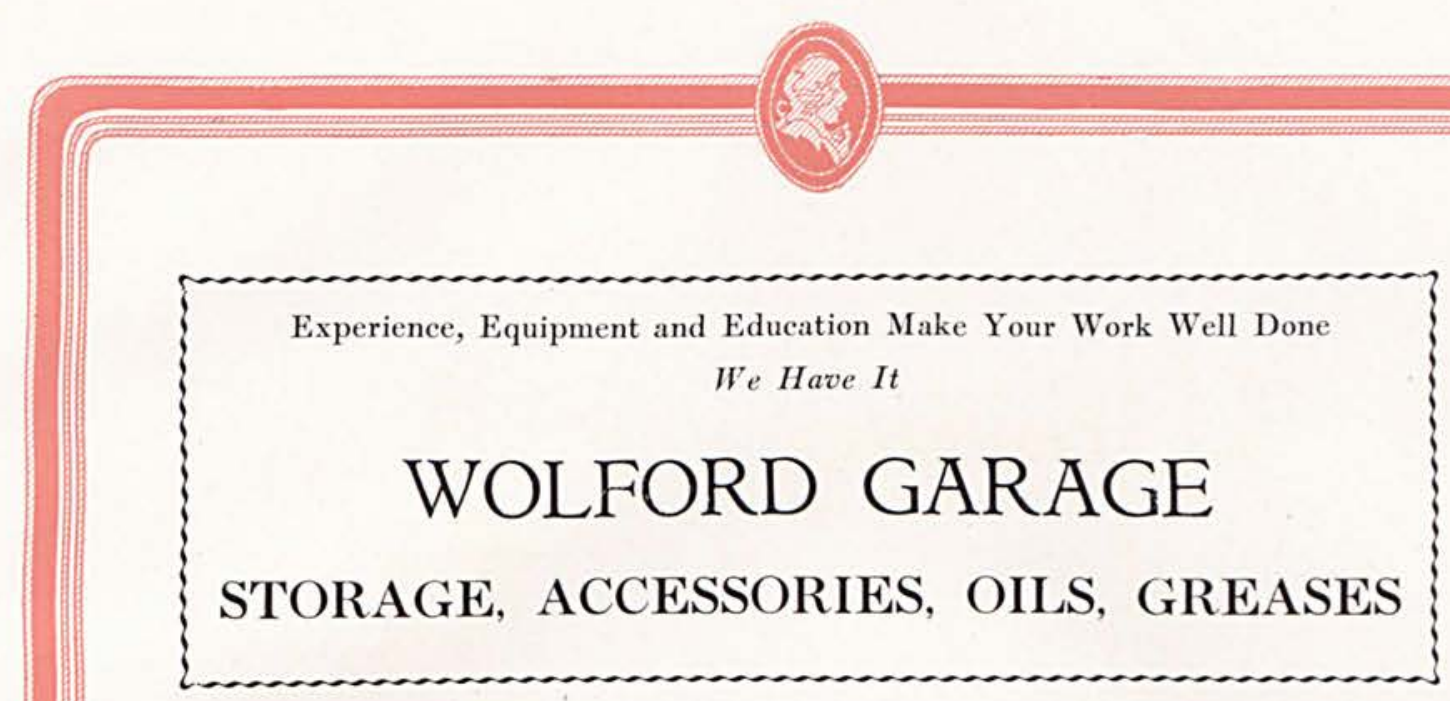

Susannah- "How do so many boys get killed in football games?" Isabel-“They kick off."

One of the "campus cut ups" was wondering the other day if it would be appropriate for a cast-off son to wear second-hand suits.

A hyprocrite is a guy who raves half the day about how beautiful his girl is, and then stands in line half the night to see a burlesque show.

Frances- "Why are you walking so slowly?"

Margaret- "Oh, so that if I fall asleep, I won't-fall so hard."

Wones-"Cheer up old man, remember that the first year of married life is the hardest."

Burke-"Yeh, I suppose after that they make rolling pins softer."

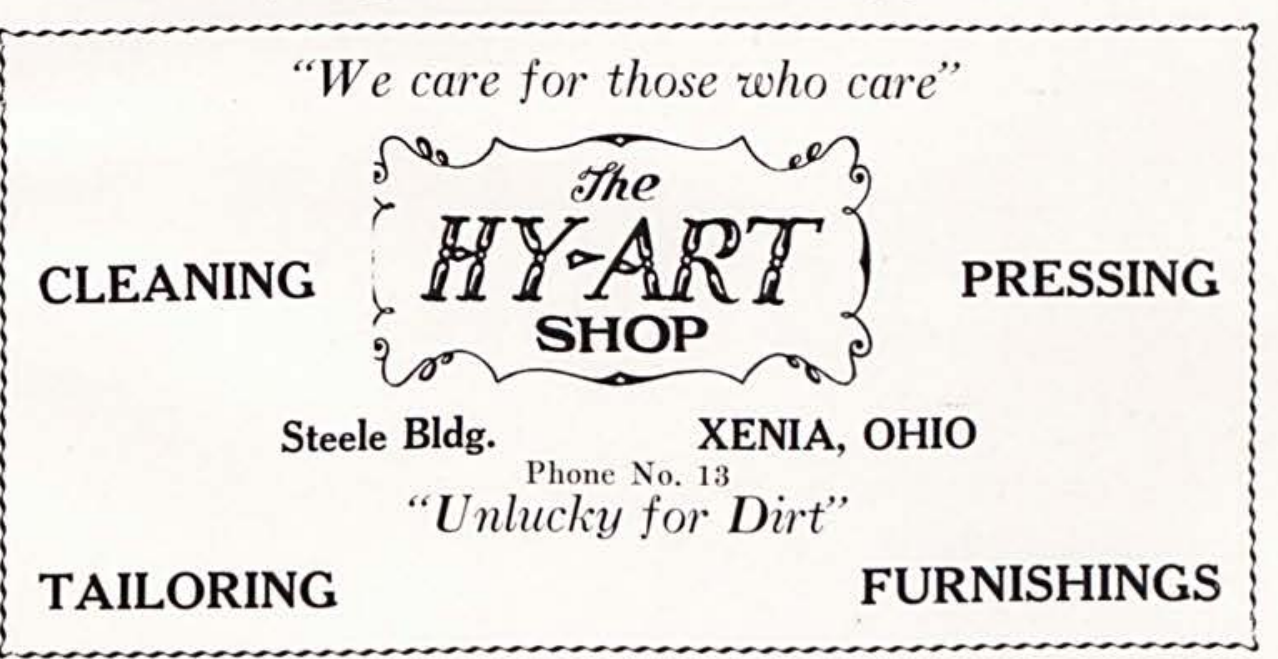

Page One Hundred and Twenty-one 


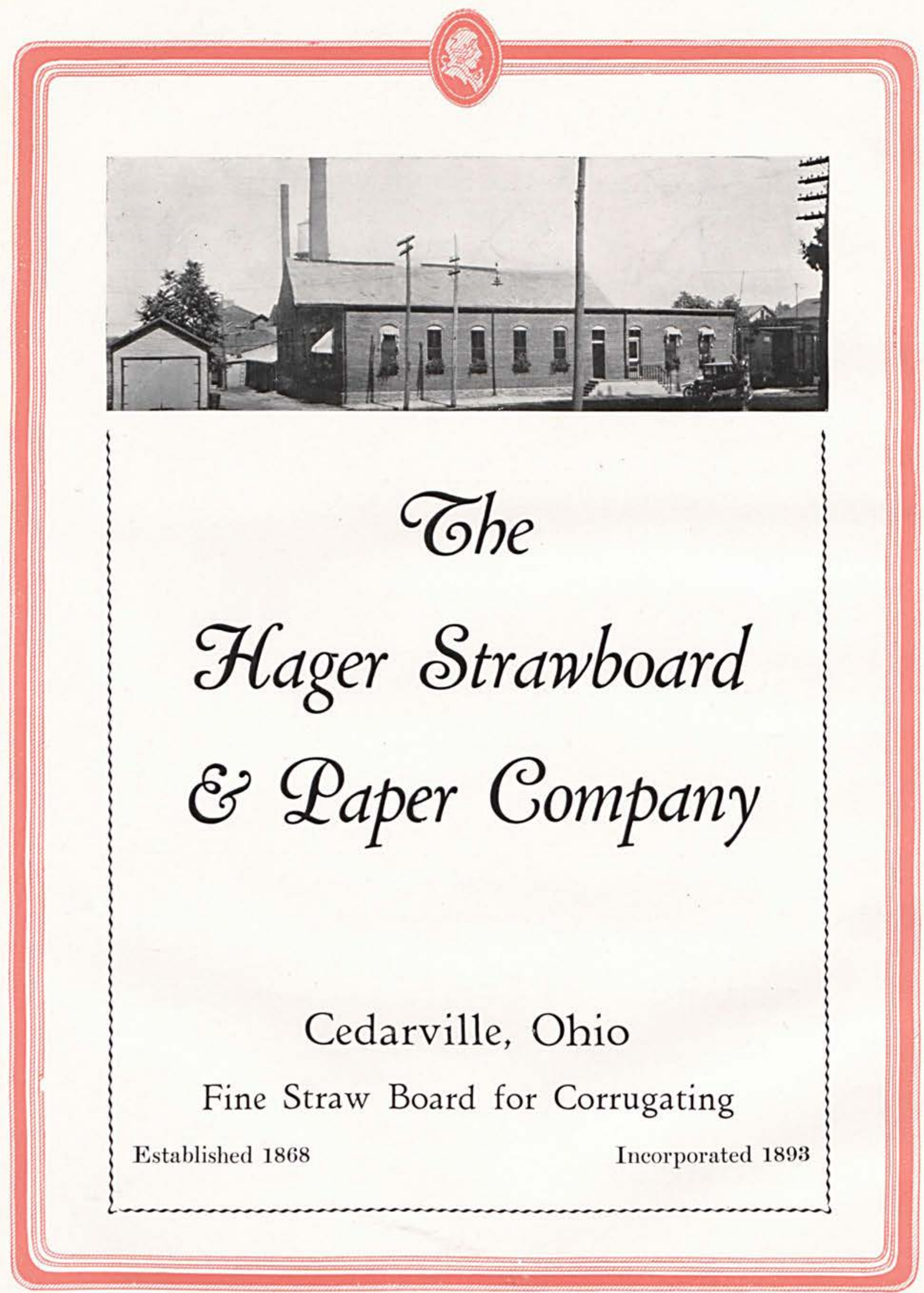

Page One Hundred and Twenty-two 


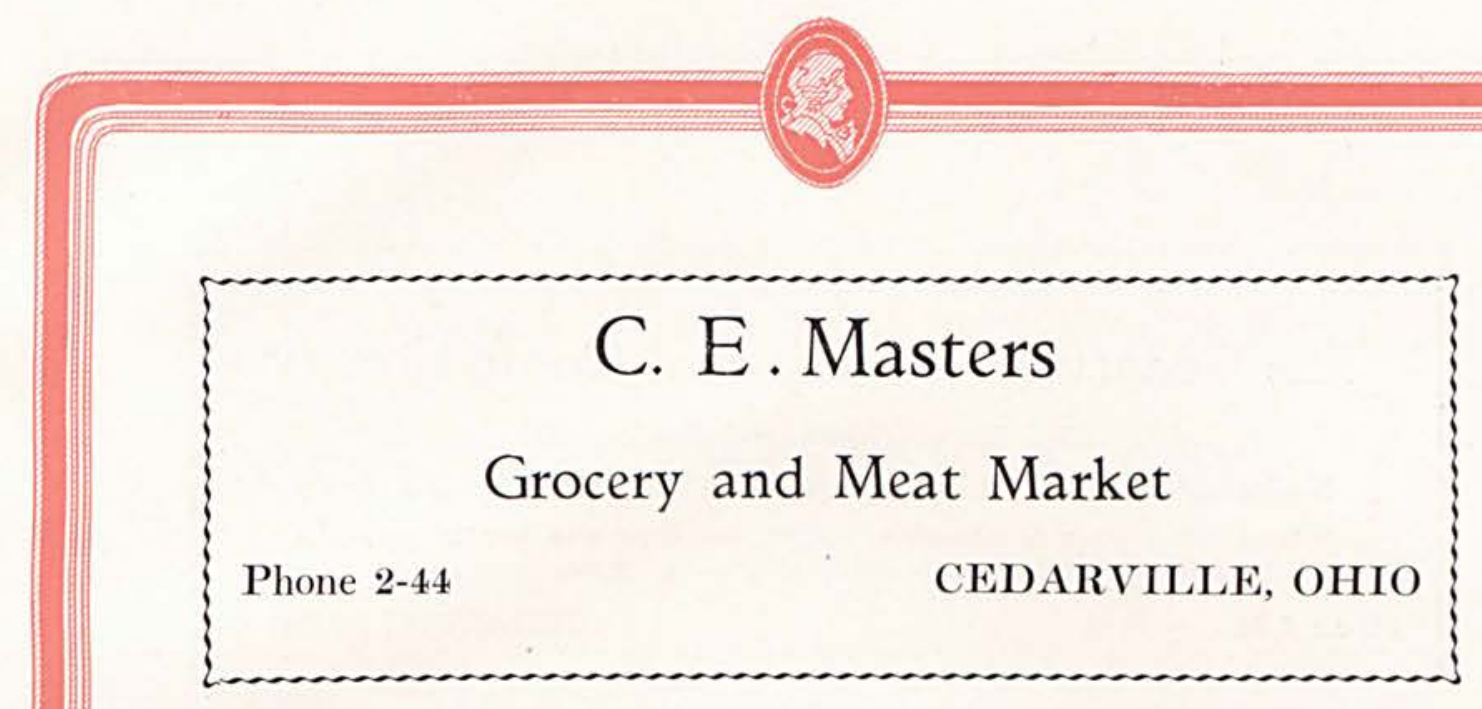

Miss Dolby - "When did Washington take his first ride, Don?"

Don Allen-"When he took a hack at the cherry tree."

The world may be going wrong for everybody else, but everything is "Jake" with Helen.

"Irish"_-"You are perfectly normal?"

"Bruiser"- "Yes."

"Irish"- "You light your cigarette with your right hand?"

"Bruiser"- - "Yes."

"Irish"- "That's not normal. Most people use a match."

Hilma- “I think necking is positively repulsive."

Mary Ruth-“I don't like it either."

Hilma- "Shake sister, we're both liars."

"Wee"- "A man just hanged himself in our cellar."

"Jake"- "Well, did you cut him down?"

"Wee"- "No, he wasn't dead yet."

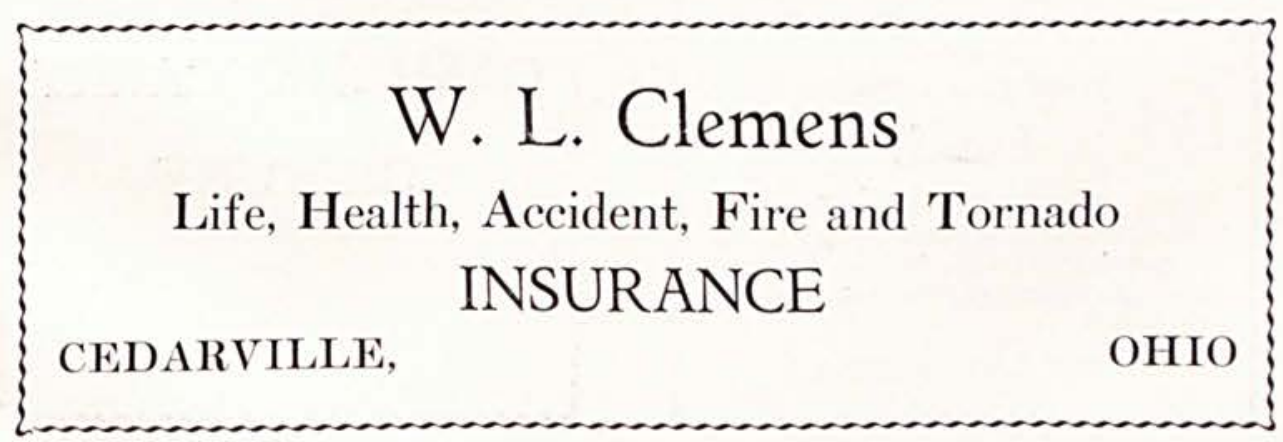




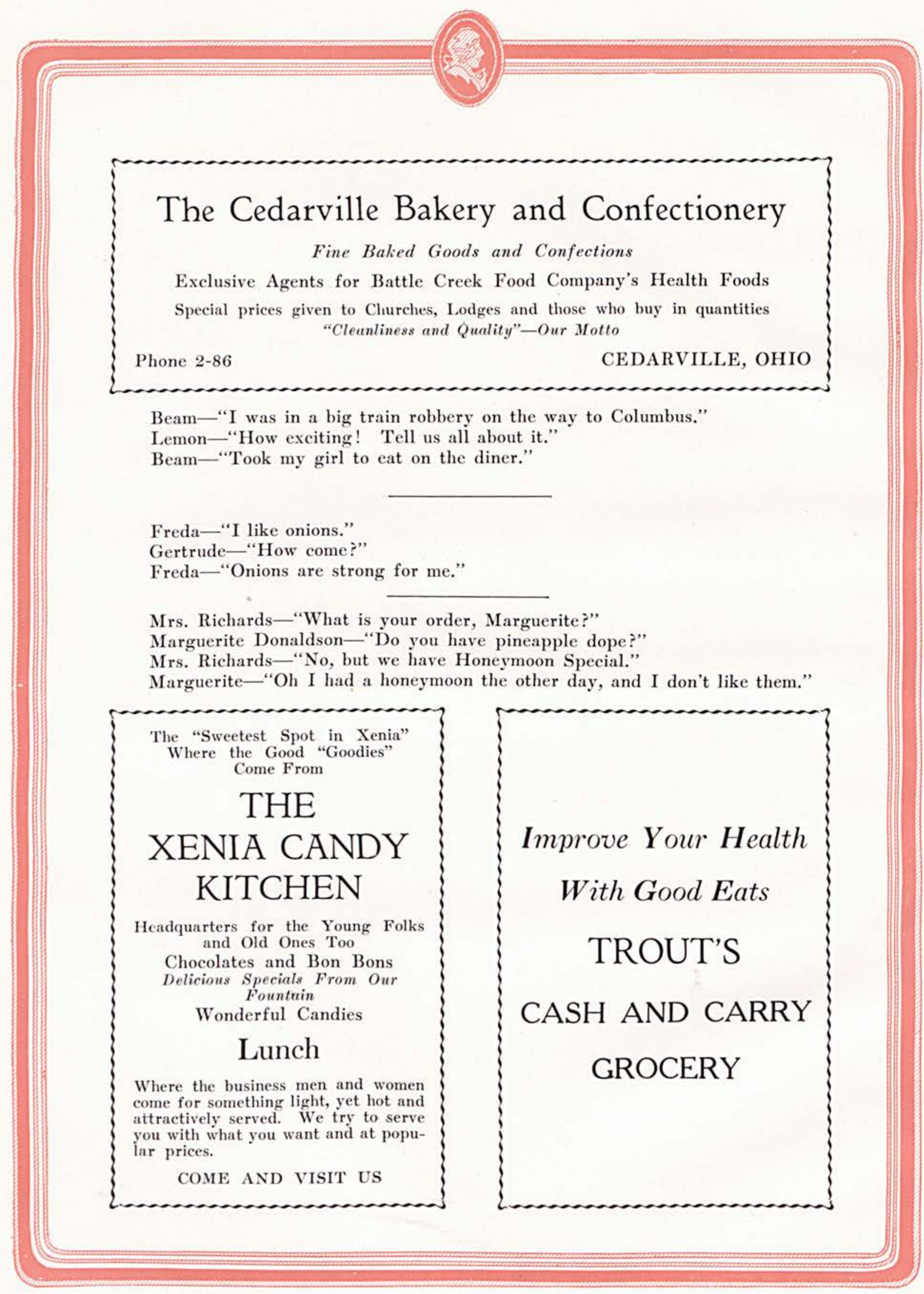

Page One Hundred and Twenty-four 


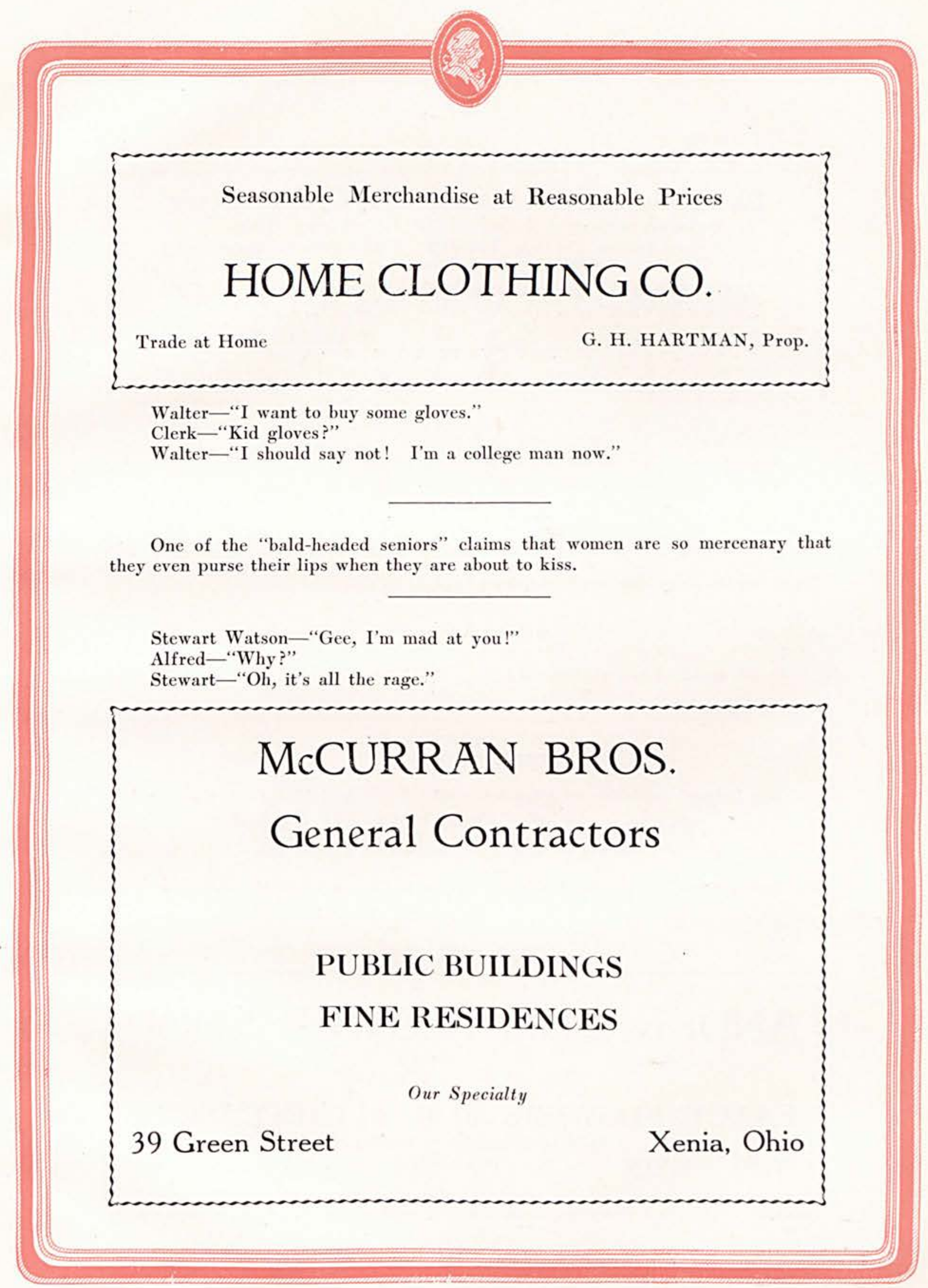

Page One Hundred and Twenty-five 


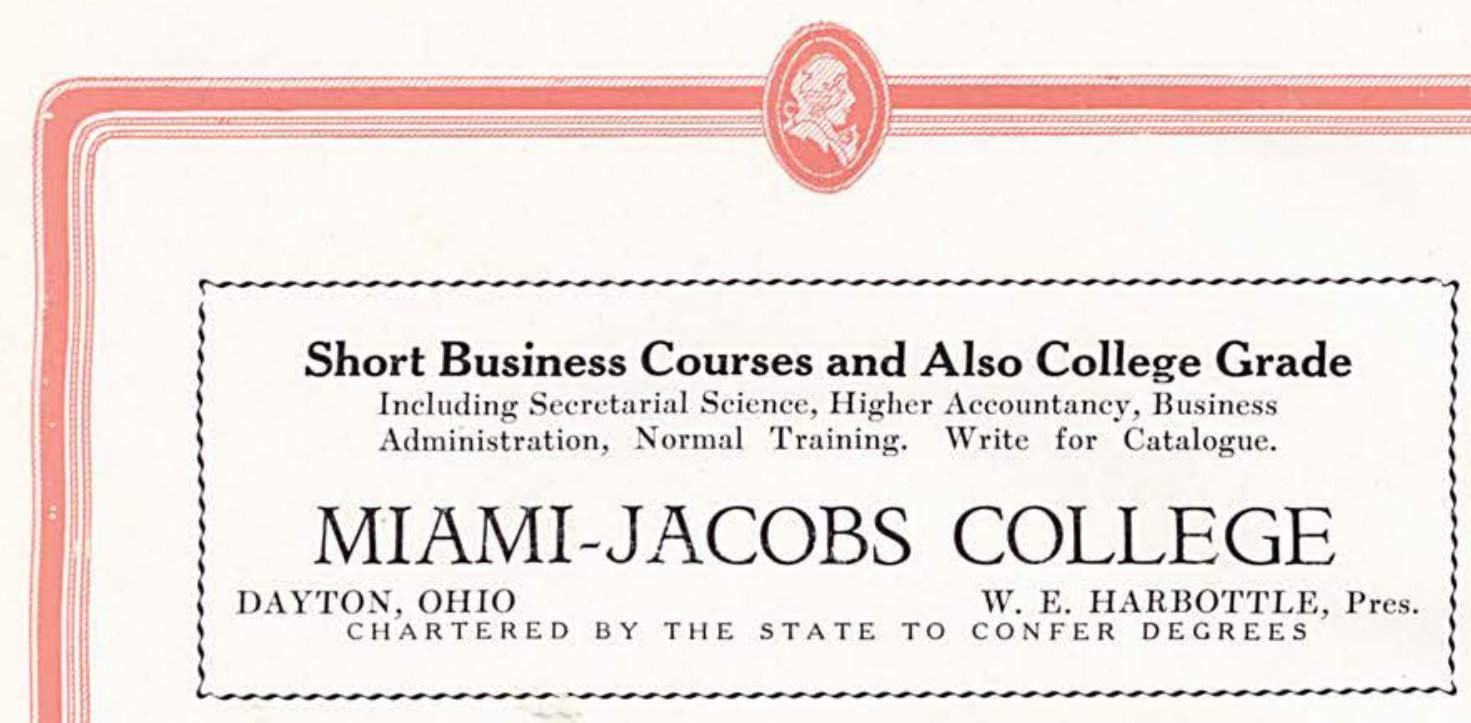

Coach Borst- "How much are your rooms?"

Night Clerk- "From six dollars, up to twelve."

Borst- "How much for all night?"

It is claimed that girls are absent-minded, but no one ever heard of a girl who shined her nose and powdered her shoes.

Coach Borst claims that there isn't a thing intellectual about long hair when your wife picks it off your coat.

Bob Cripps' definition of an ignoramus: "Anybody who differs with me."

Brownie can't understand why he has to go to bed when he isn't sleepy and get up when he is.

\section{ANDERSON'S FLOWER SHOP}

"Say It With Flowers"

\section{FANCY FLOWERS FOR ALL OCCASIONS}

101 W. Main Street

Flowers Telegraphed Everywhere

Phone 681-R

Xenia, Ohio

Page One Hundred and Twenty-six 


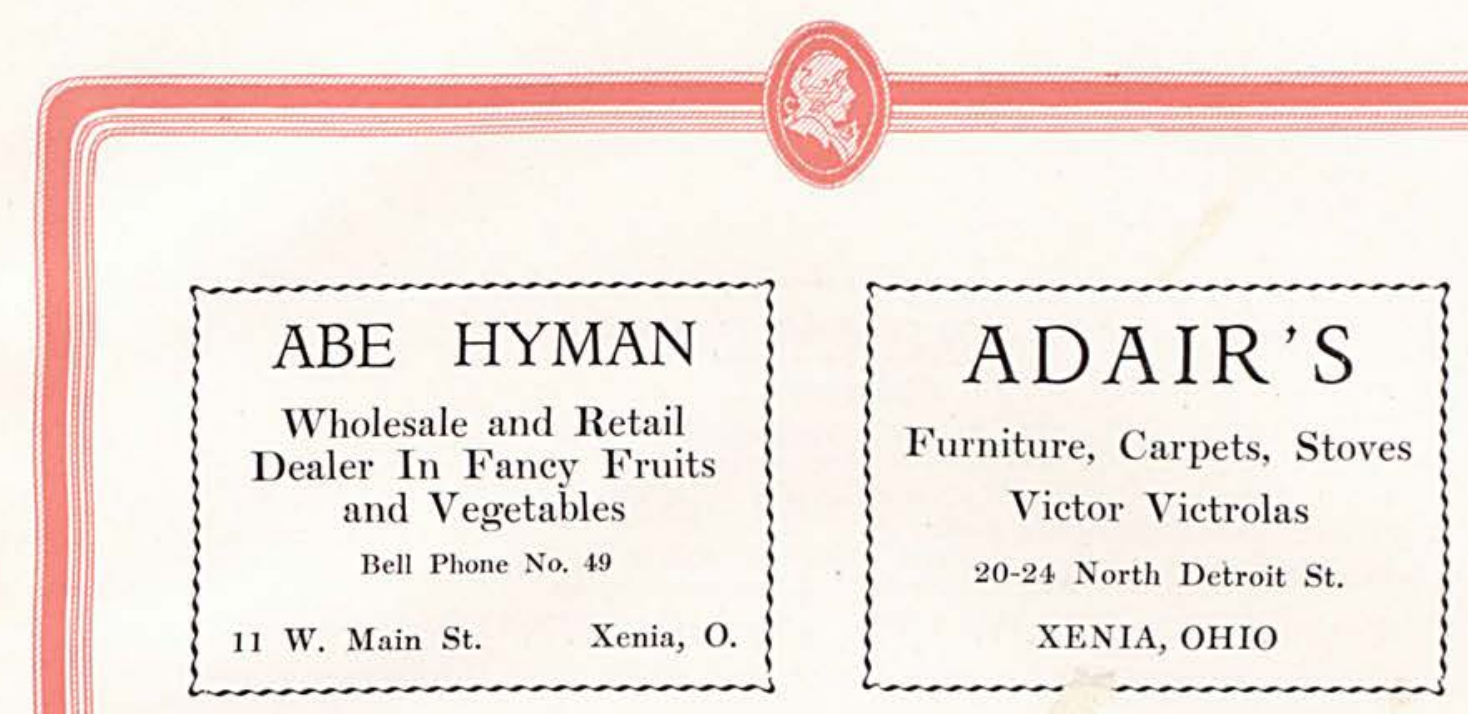

Judging from the Senior Class, we would think that a college is a place where you eat, drink, and be married.

Eva-"You men are all alike."

Fisher-"Who told you that?"

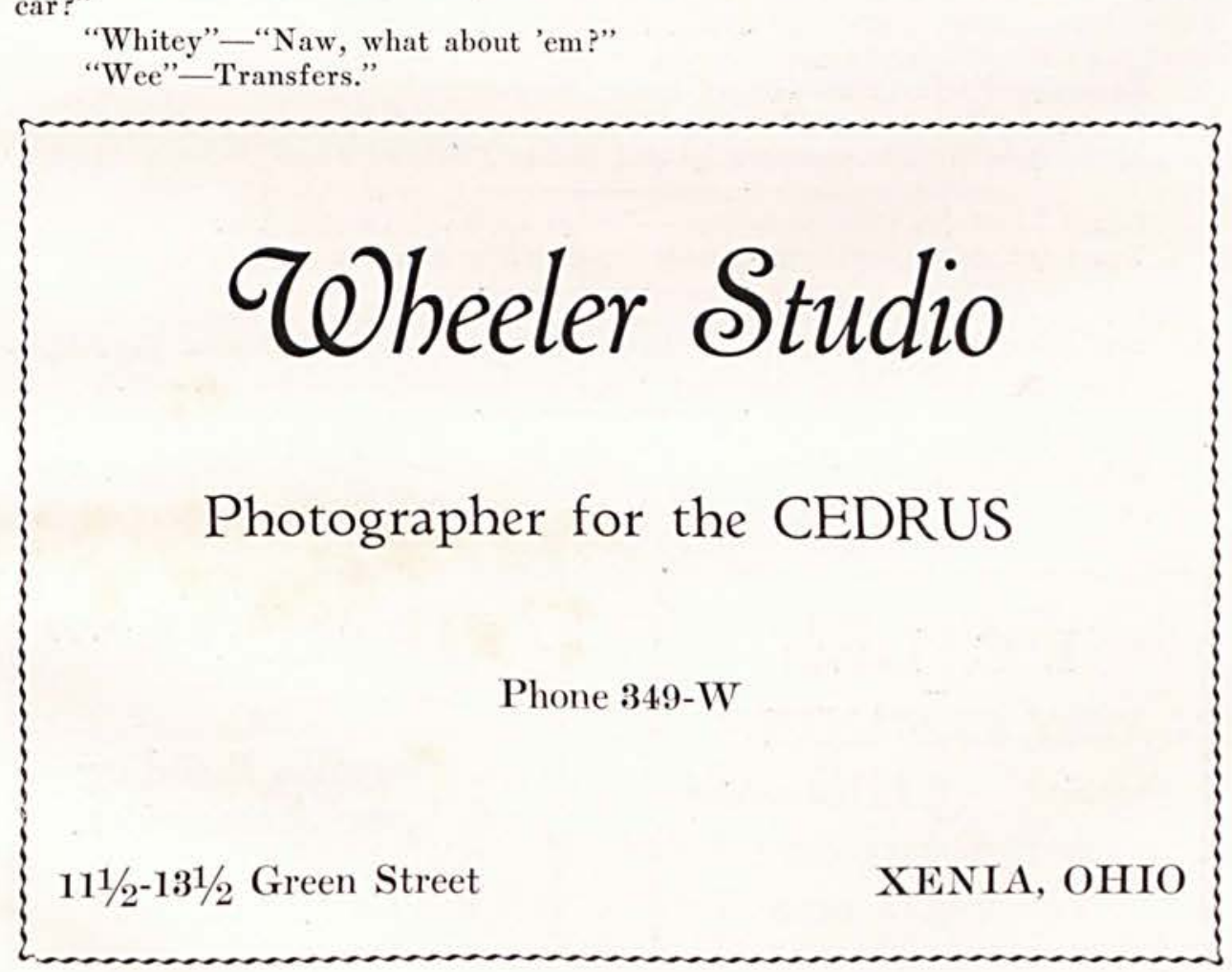

Page One Hundred and Twenty-seven 


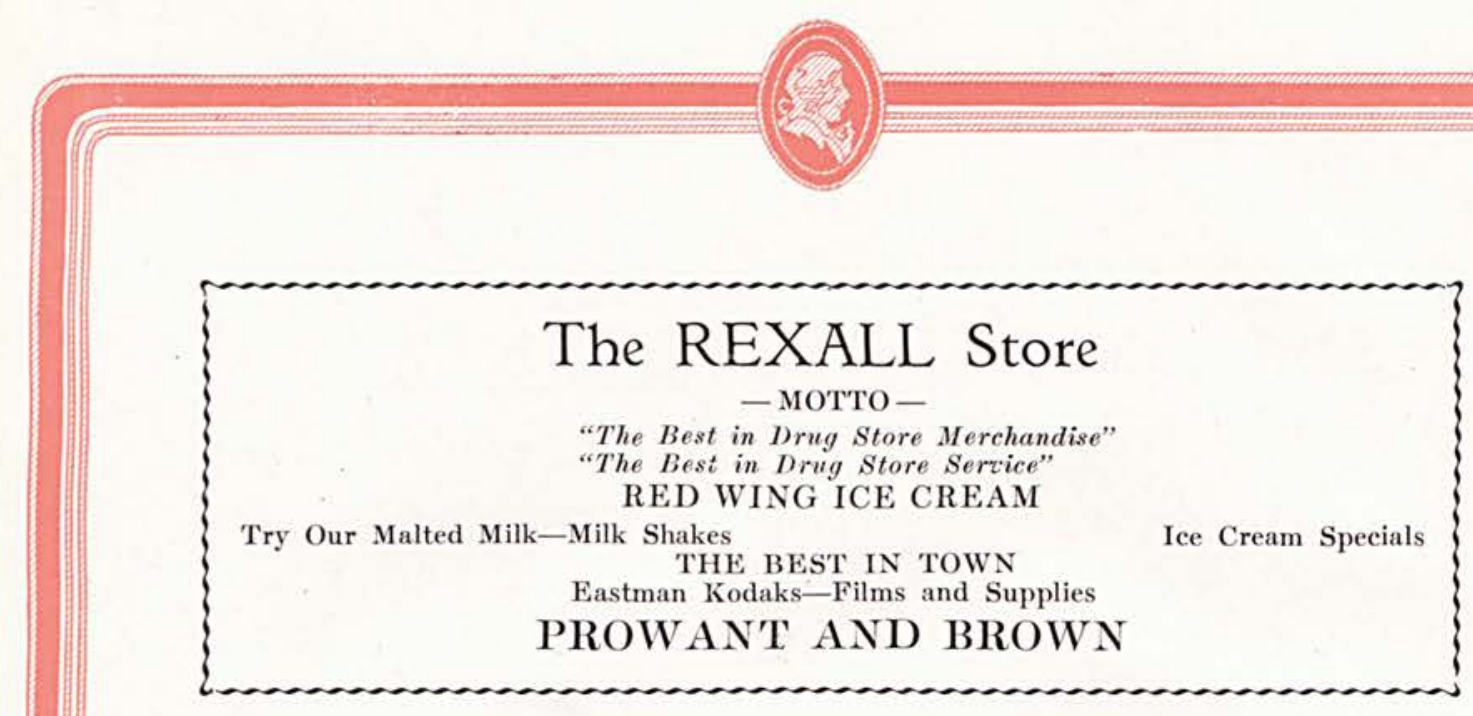

Hilma- “I just couldn't think of anything poisonous enough to call him." Jean- "Did you call him a bootlegger?"

It has been claimed that the only job Bob Jacobs ever had was when he labored under a delusion.

Alberta- "What do the three balls in front of a pawn shop mean?"

Dallas- “Two to one you won't get it back."

Kennedy-“I just shot a dog."

Weimer-"Was he mad?"

Kennedy_-"Well he wasn't very well pleased."

Coach Borst (on Cincinnati trip) - "Shall I take you to the Zoo?"

Team (in unison) - "If they want us, they'll come after us."

No Cedarville College student could ever have been the author of the following statement: "Half the girls long to kiss and the other half kiss too long." husky.

No, Freshmen, a man isn't necessarily full of corn just because his voice is
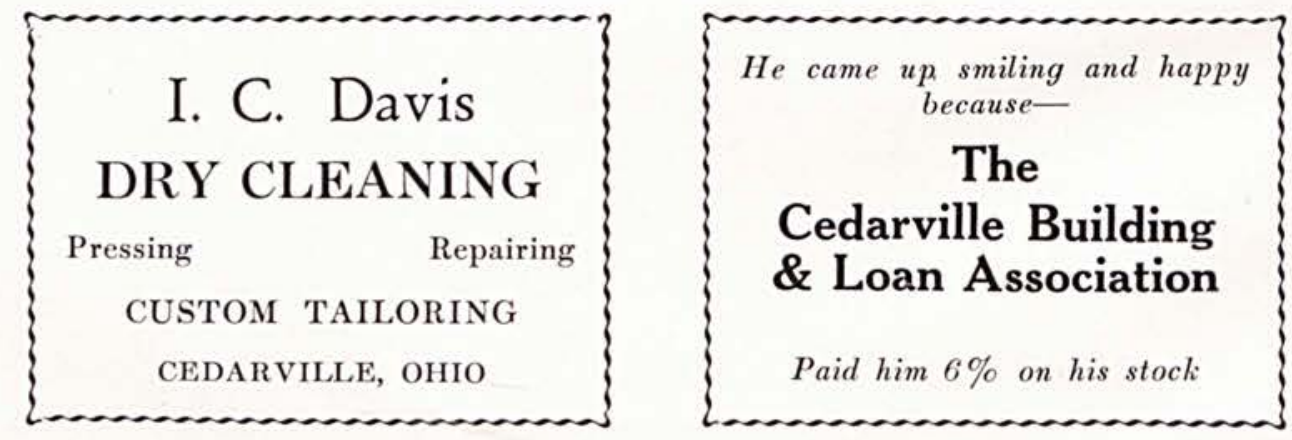

Page One Hundred and Twenty-eight 


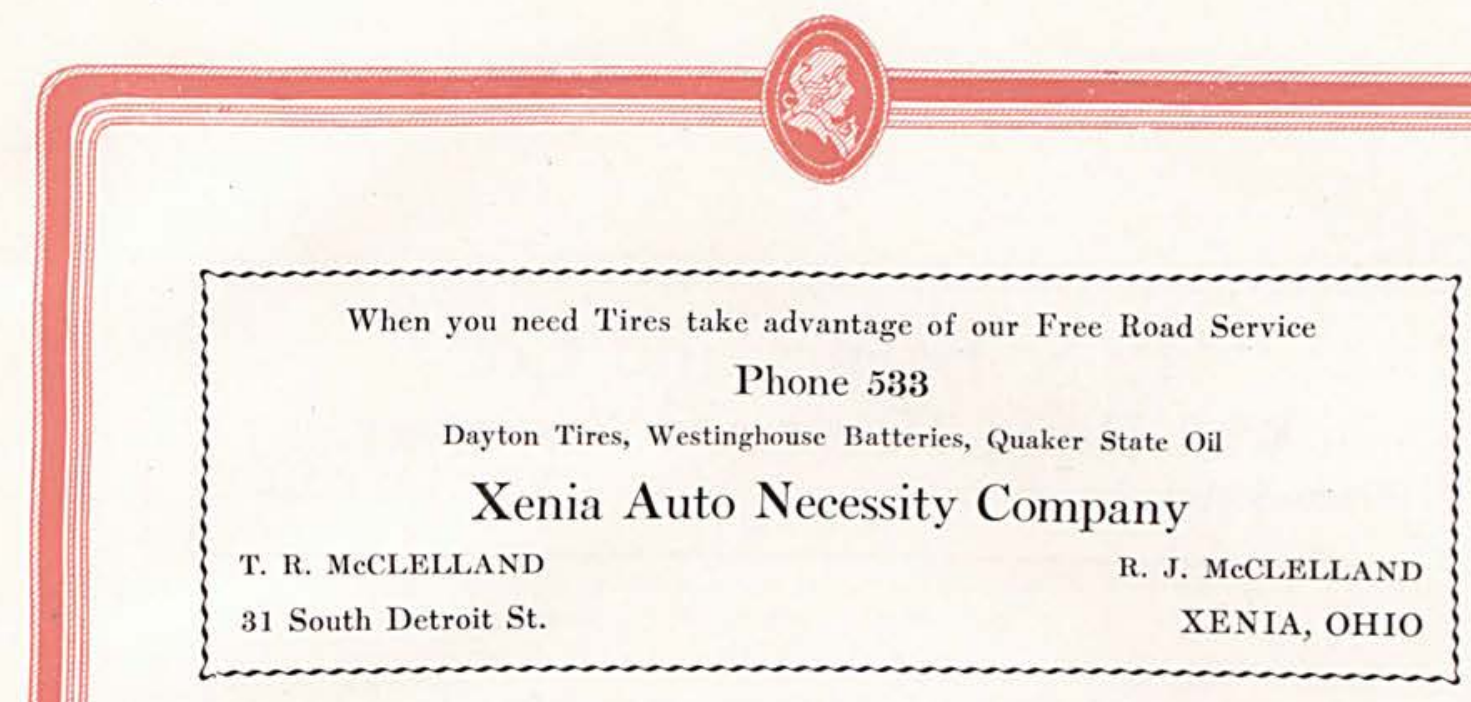

\section{A BED-TIME STORY FOR FRESHMEN}

Once upon a time, we heard a story (and on very good authority) about a little boy and a little girl who liked each other very much. Now it happened that the little girl was a preacher's daughter, and on a certain night, when the little boy had a date with the little girl, she had to go to church (as all good preacher's daughters do) so the little boy went around to the church in a neighboring town not far from Cedarville and had to content himself waiting in the lobby until the pride of his heart had finished her duties at the piano. Now the hero of our story had arrived on the scene of action just as the preacher was in the midst of his discourse, and as he was rather tired, he dreamed lazily away until the preacher had finished. However, as he heard the first notes of the closing song being played, he spruced up and thought that e'er long he could feast his eyes on his lady fair. But the little boy was very much dismayed when he heard the congregation burst forth into a negro spiritual, and he realized he had made a mistake in the church. Which all goes to show, little Freshmen, that denominations do make a difference!

\section{INTERESTING FACTS BROUGHT OUT BY THE FRESHMEN}

"March isn't the only month it's windy in Washington."

"In Mexico they run for president one day and run for their lives the next."

"Cedarville College is one college where boys about catch that peculiar malady known as 'Fraternity Grippe.'”

"How doth the busy little B

Delight to joke and tease?

He hides himself from you and me

And all we pull are D's."

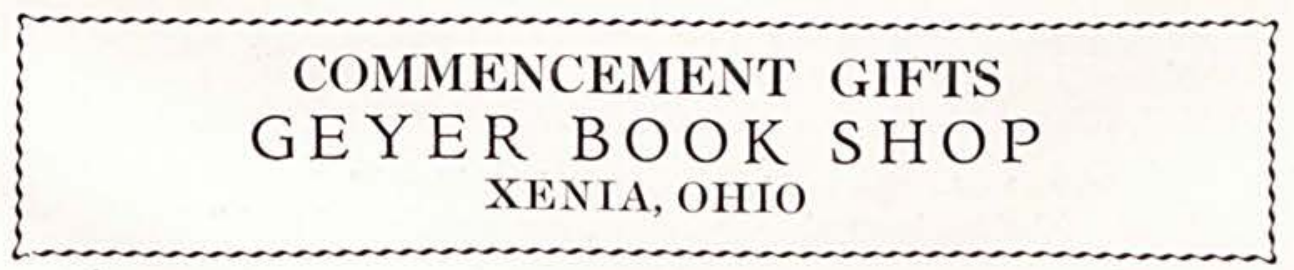




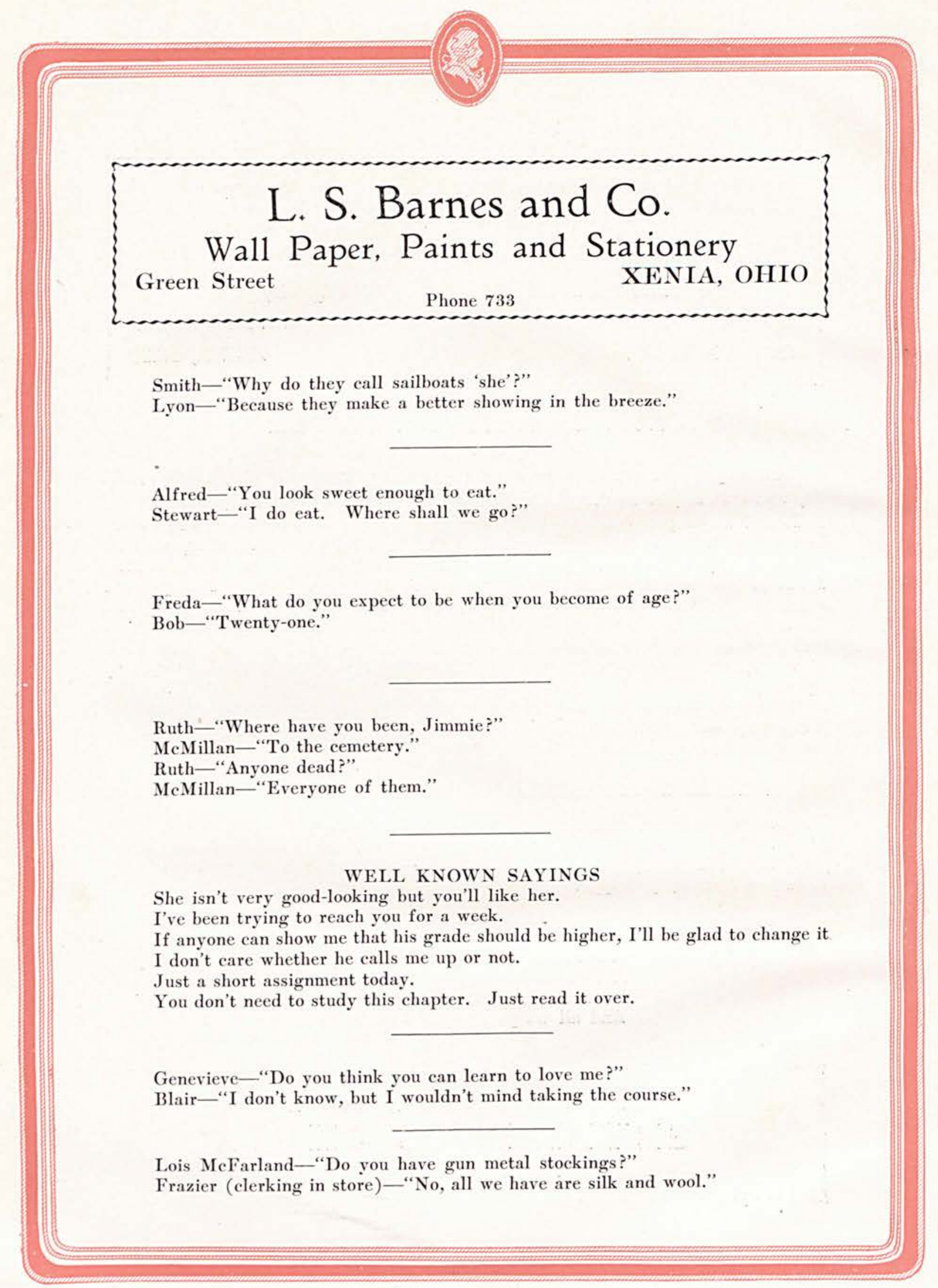

Page One Hundred and Thirty 


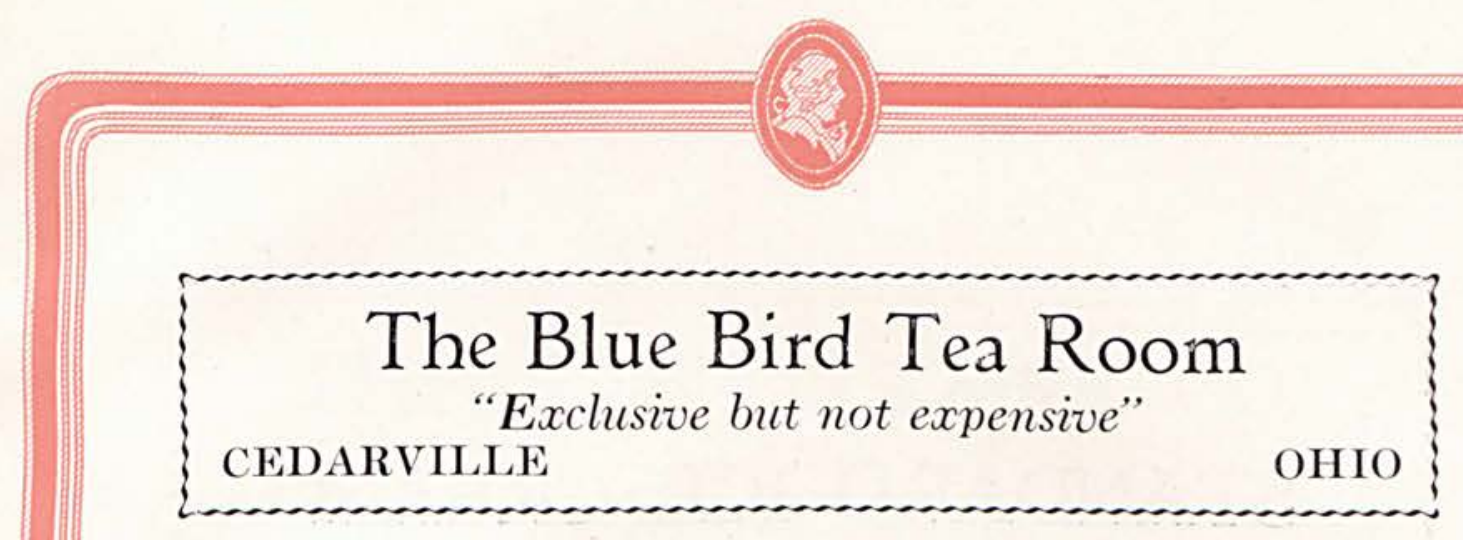

One of the football players upon being asked why he did not have a date replied: "My girl penalized me fifteen days for holding."

A member of the first year Journalism Class thinks that a "newspaper scoop" has a handle on it.

Armstrong-"What killed that aviator at Osborne?"

Fisher-"A severe sinking spell."

McNeel- "What is the temperature of a kiss?"

Helen- "I'll bite. What is it?"

MeNeel- "Two in the shade."

Since Dorothy bought her car, Kyle says that he doesn't want to keep the "Wolff" from the door.

Mayor McFarland-“Guilty or not guilty?"

Kenny-“You guess first."

Red Osburn - "Would you believe it, I only got forty in that history exam?" Anita- "Dearie, you don't know the half of it."

\section{MODERN MEMORIAL ART}

In all its beauty,-with all its symbolism-expression of love and devotion,- - and possessing true historical significance-

All of these qualities are found in the Memorials and Markers furnished by

\section{The George Dodds and Sons Granite Company}

XENIA, OHIO.

Page One Hundred and Thirty-one 


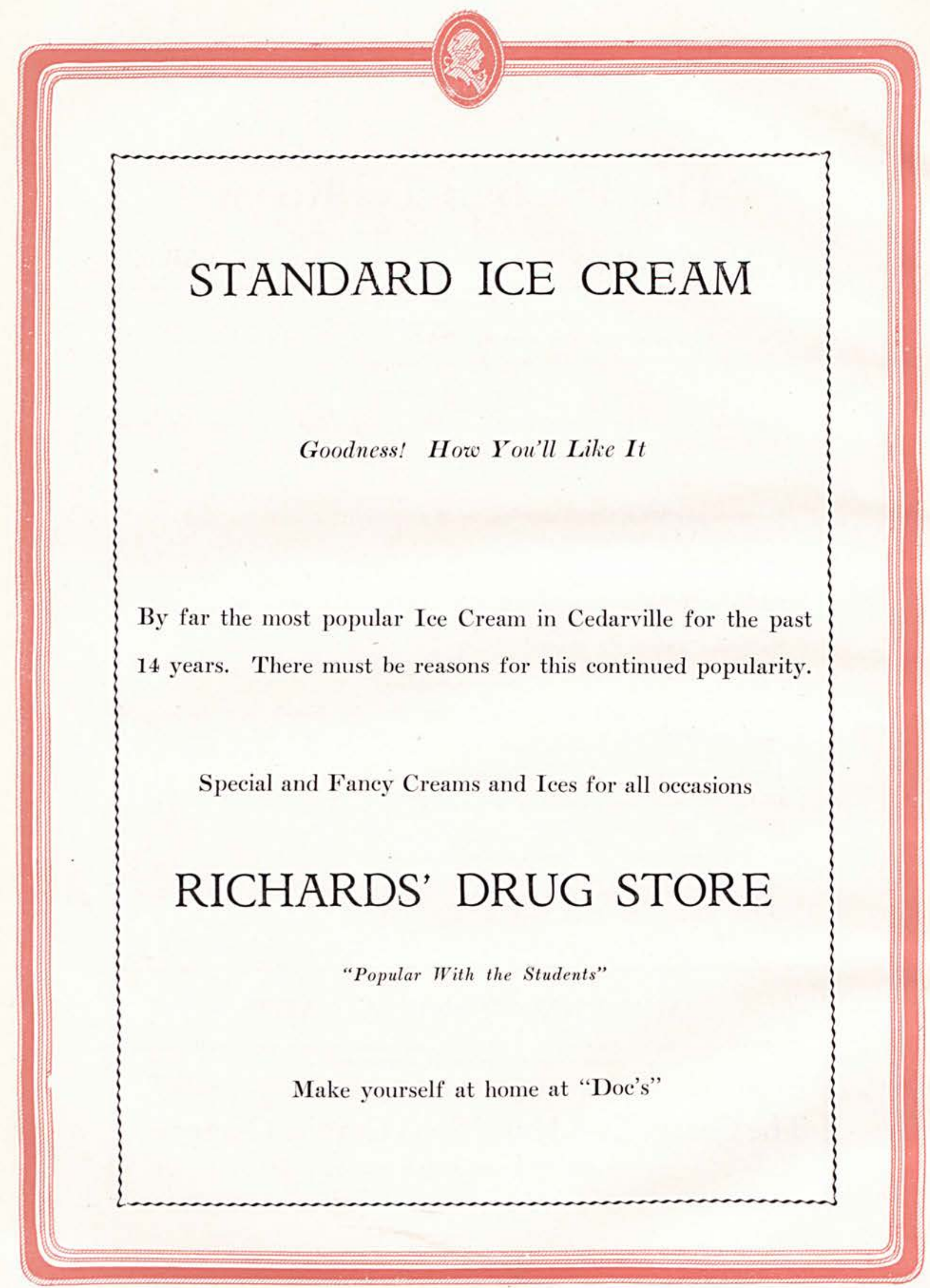

Page One Hundred and Thirty-two 


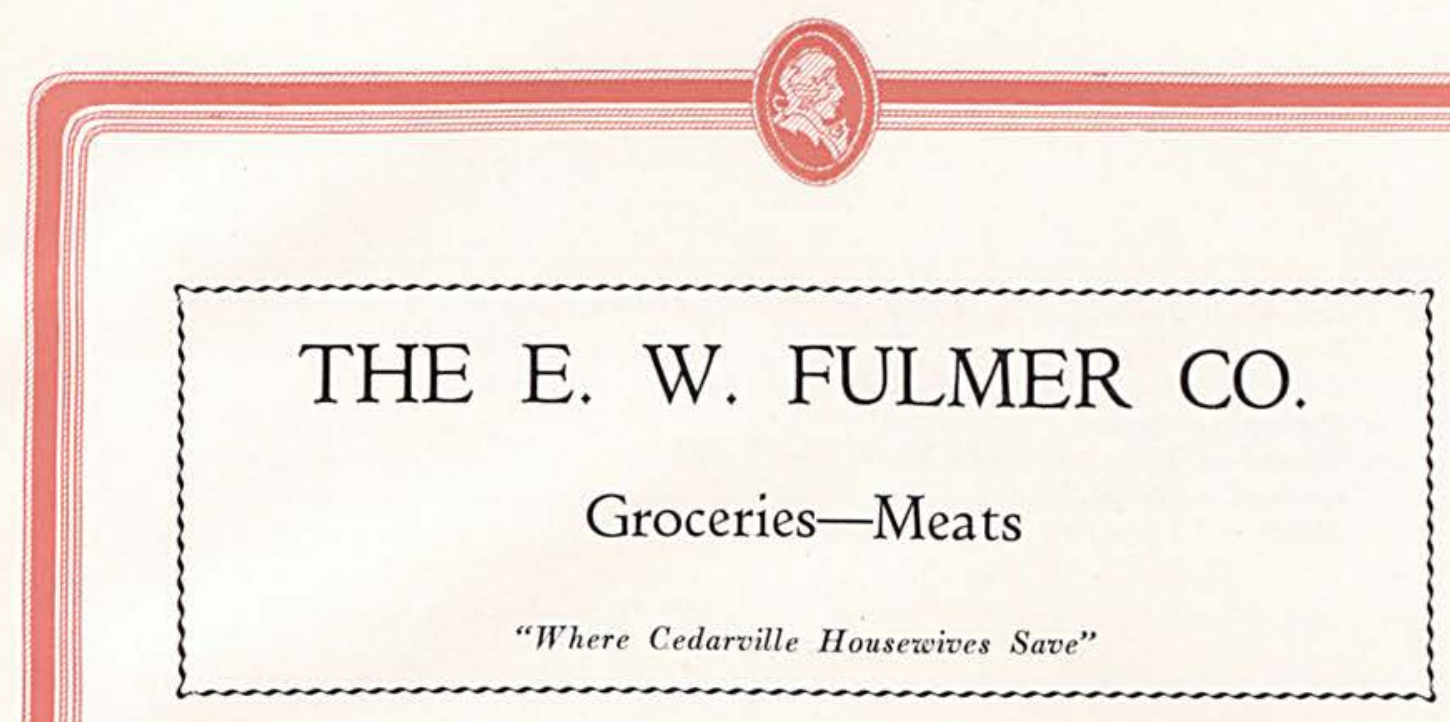

Delmar- "Hey, you going to class today?"

Tommie - "What's the matter with you, I went yesterday."

Hilma- "I've got a terrible sore in my mouth."

Wendell- "What's the matter?"

Hilma- "Ulcer, I jist don't know."

Clarence Lyon-“"Is this a one-way street?"

Marshall MeLean- "Yes, and there ain't no two ways about it."

Miss Dean-“Now, Brenton, don't you think you had better turn the page?" You have already translated ten lines on the following page."

Rozella- "Did you ever take chloroform?"

Mary Jones - "No, who teaches it?"

Wilma- "I'm nobody's fool."

Lee-“I know, but somebody may take you yet."

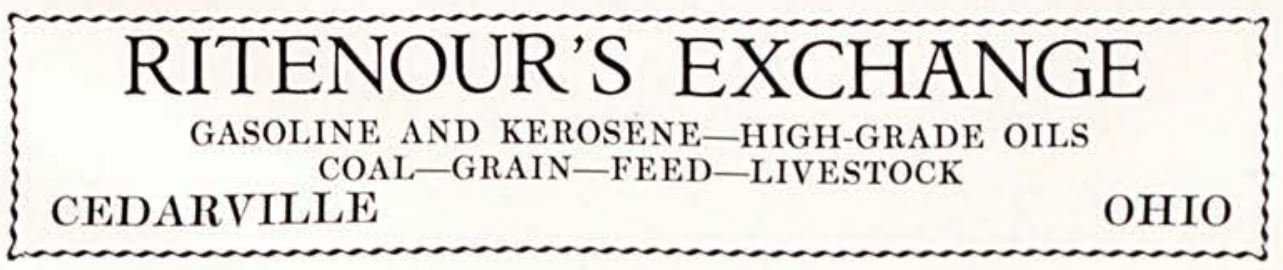


"Ethan"- “Jevver see me before?"

"Bruiser"- "No."

"Ethan"- "You know who I am?"

"Bruiser"— “Nah."

"Ethan"- "Then you don't know who I am?"

"Bruiser"- “Nope."

"Ethan"- "Then how do you know it's me?"

Kenneth Little claims that an accordion is nothing but a stretched fiddle.

Norma- "I see they have published a dictionary containing 5,000 extra words." Coach-“Great Scott, for heaven's sake, don't tell your sister." peep."

Weimer (passing Oglesbee's Dorm at 11 P. M.)-“"As ye show, so shall we WREN'S

For Fifty-one Years

A Store With

Public Confidence

Springfield, Ohio

Page One Hundred and Thirty-four: 


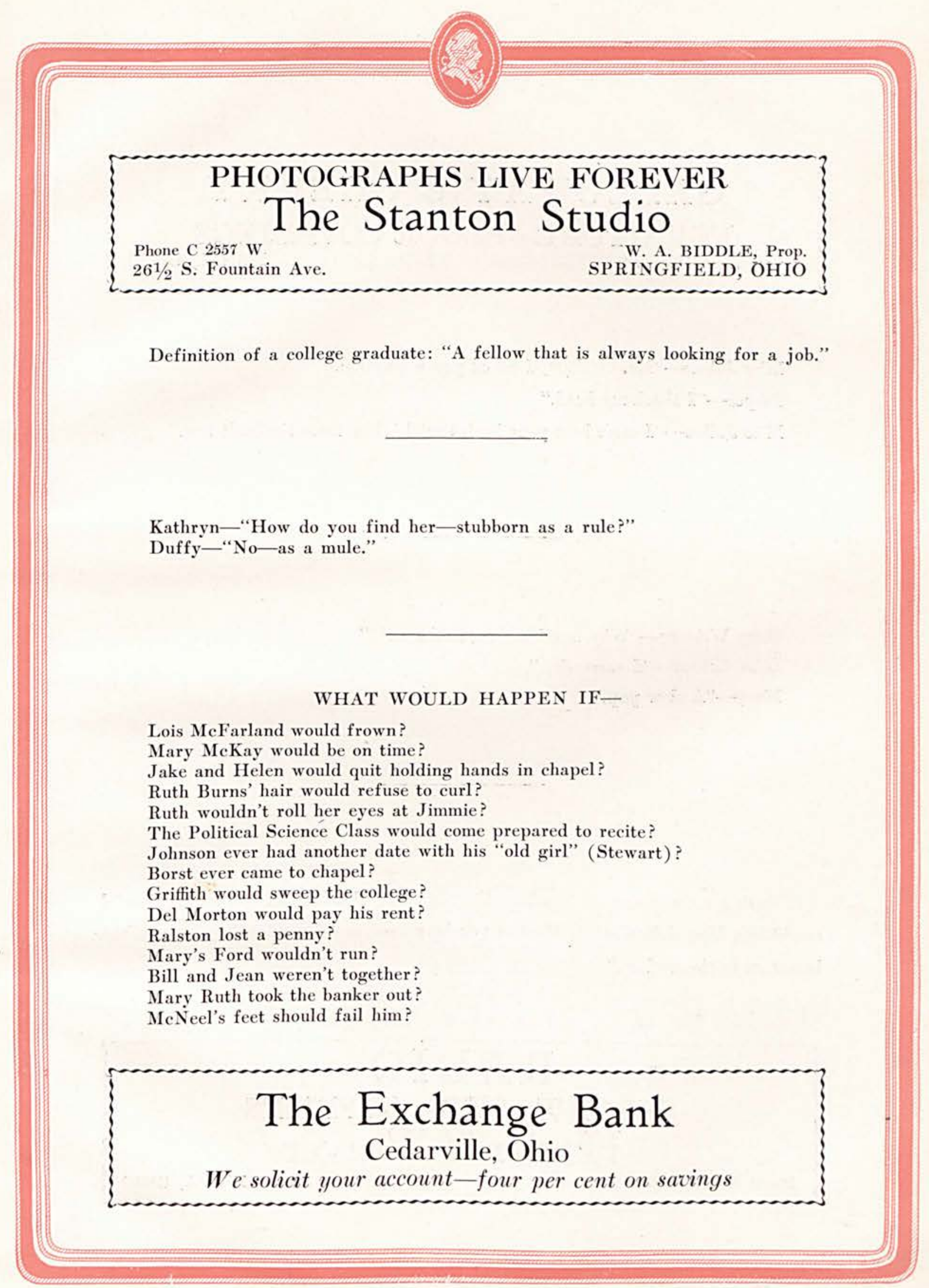

Page One Hundred and Thirty-five 


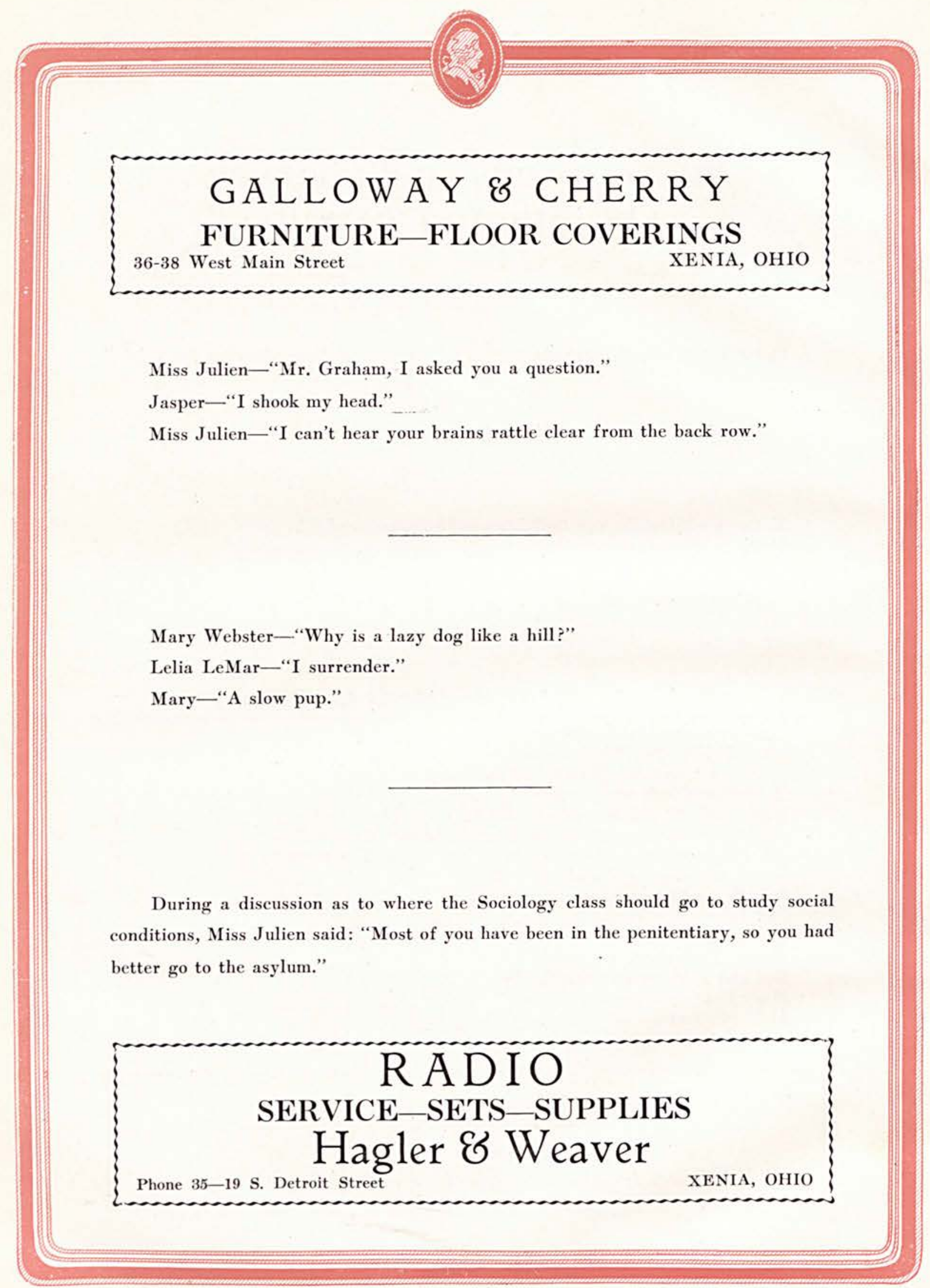

Page One Hundred and Thirty-six 


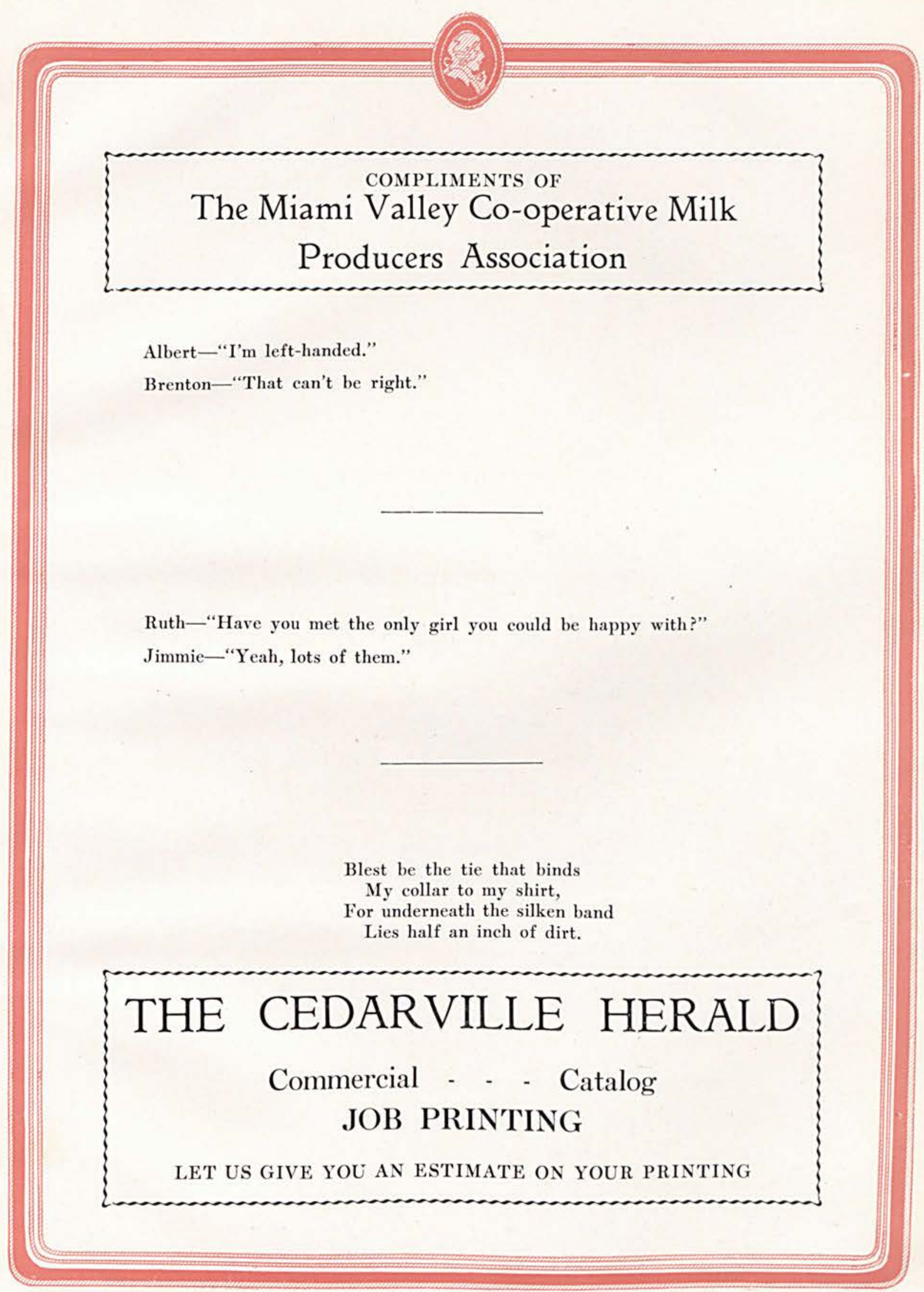

Page One Hundred and Thirty-seven 


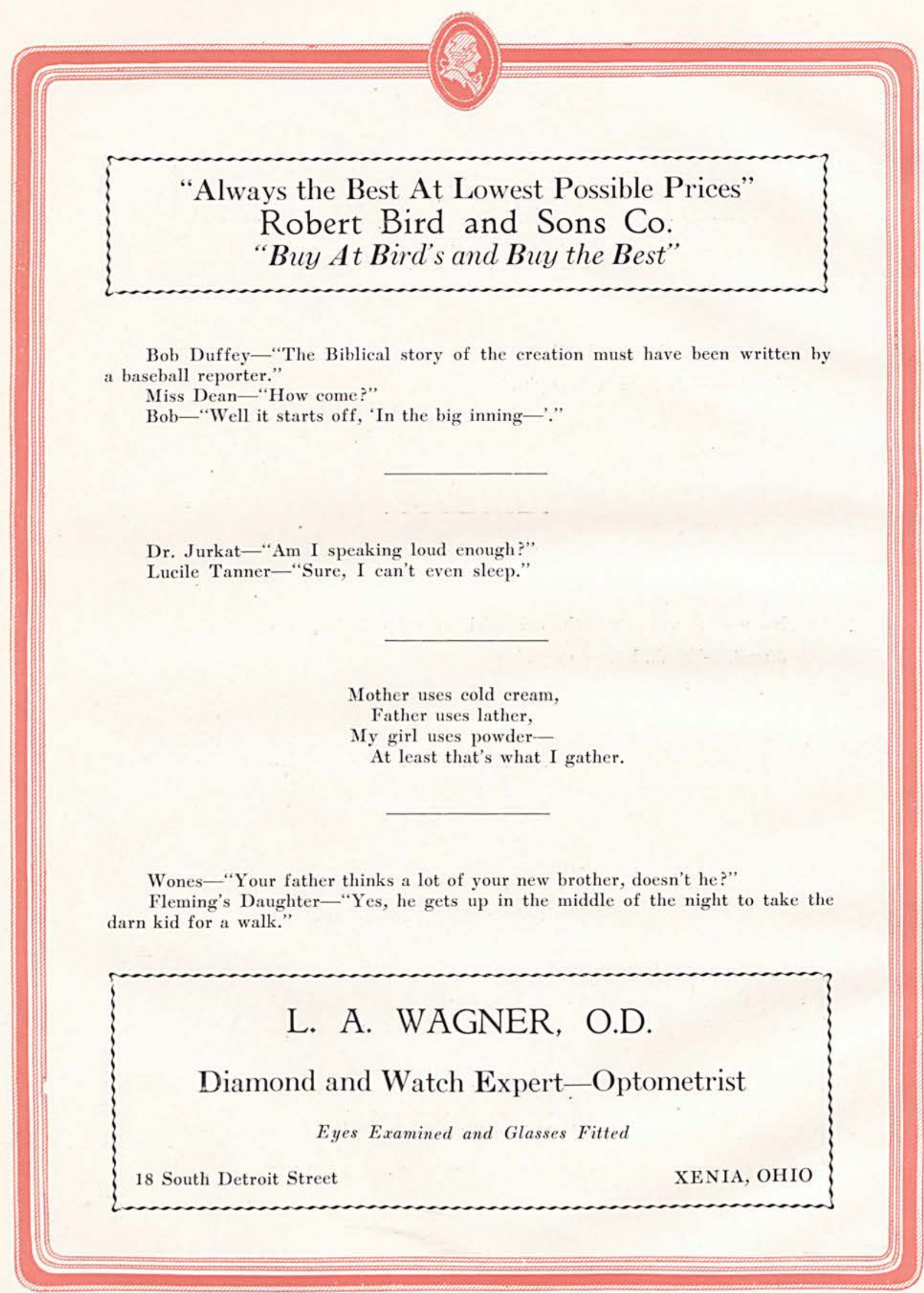

Page One Hundred and Thirty-eight 


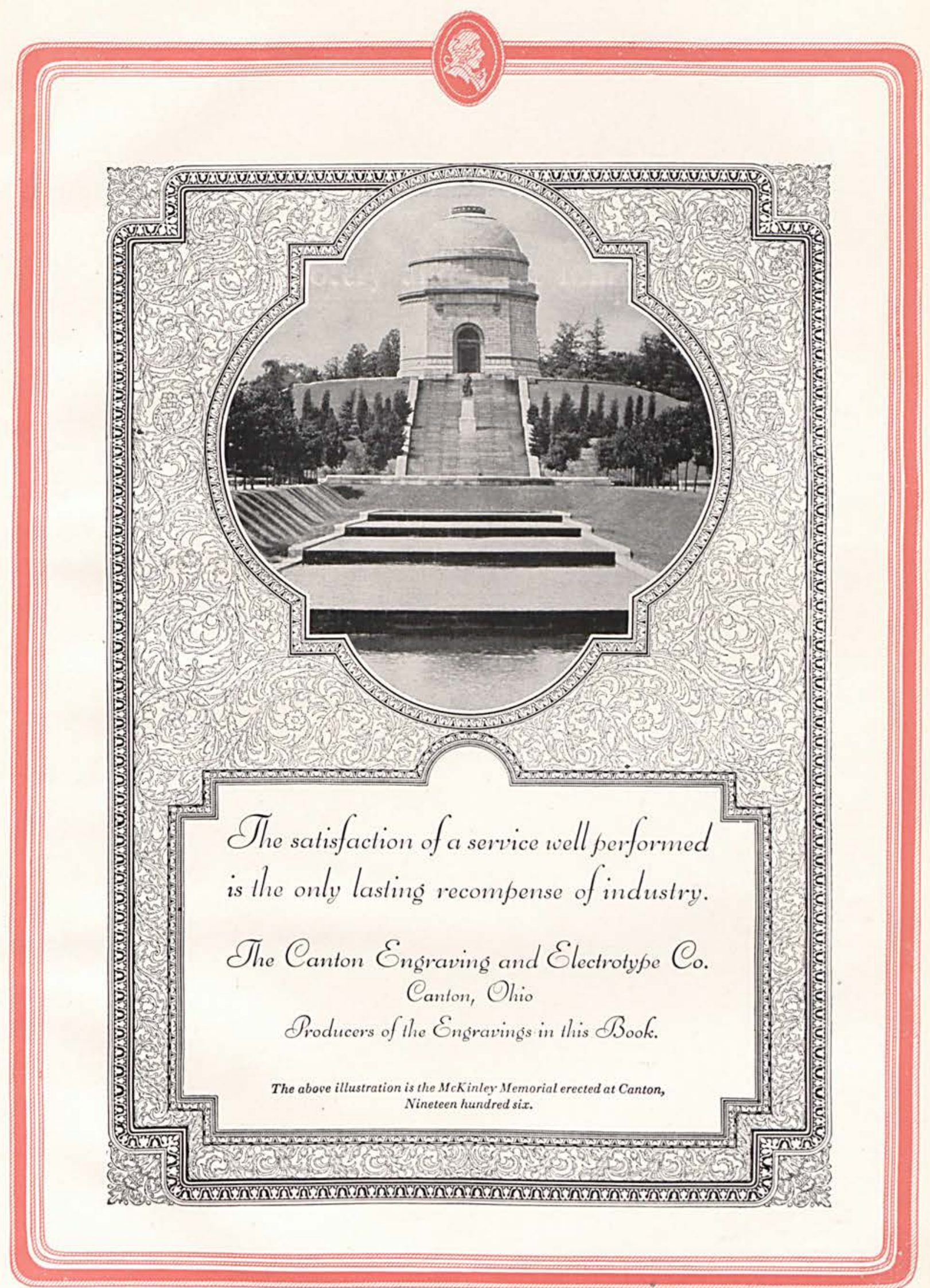

Page One Hundred and Thirty-nine 


\section{Commencement Day}




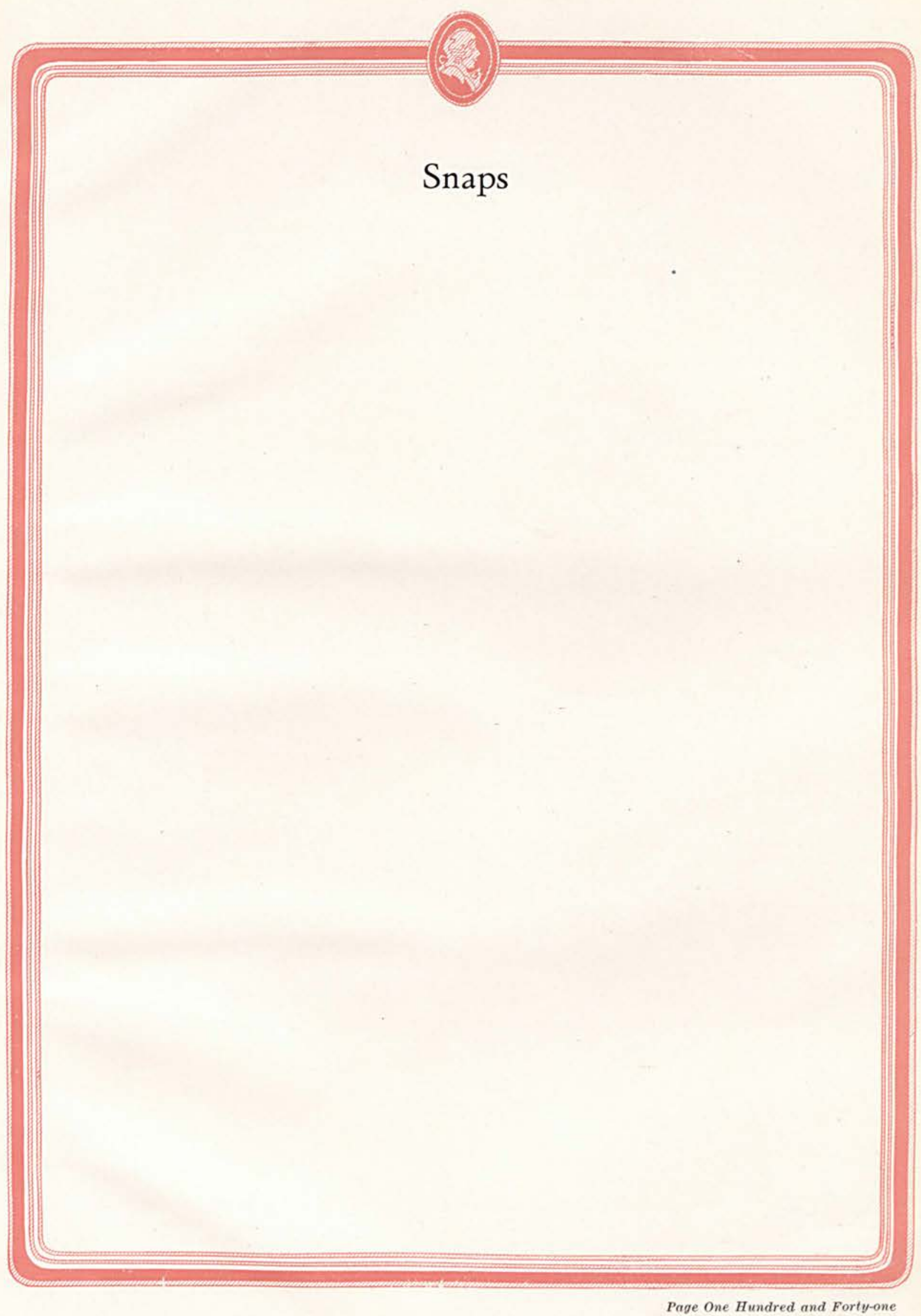




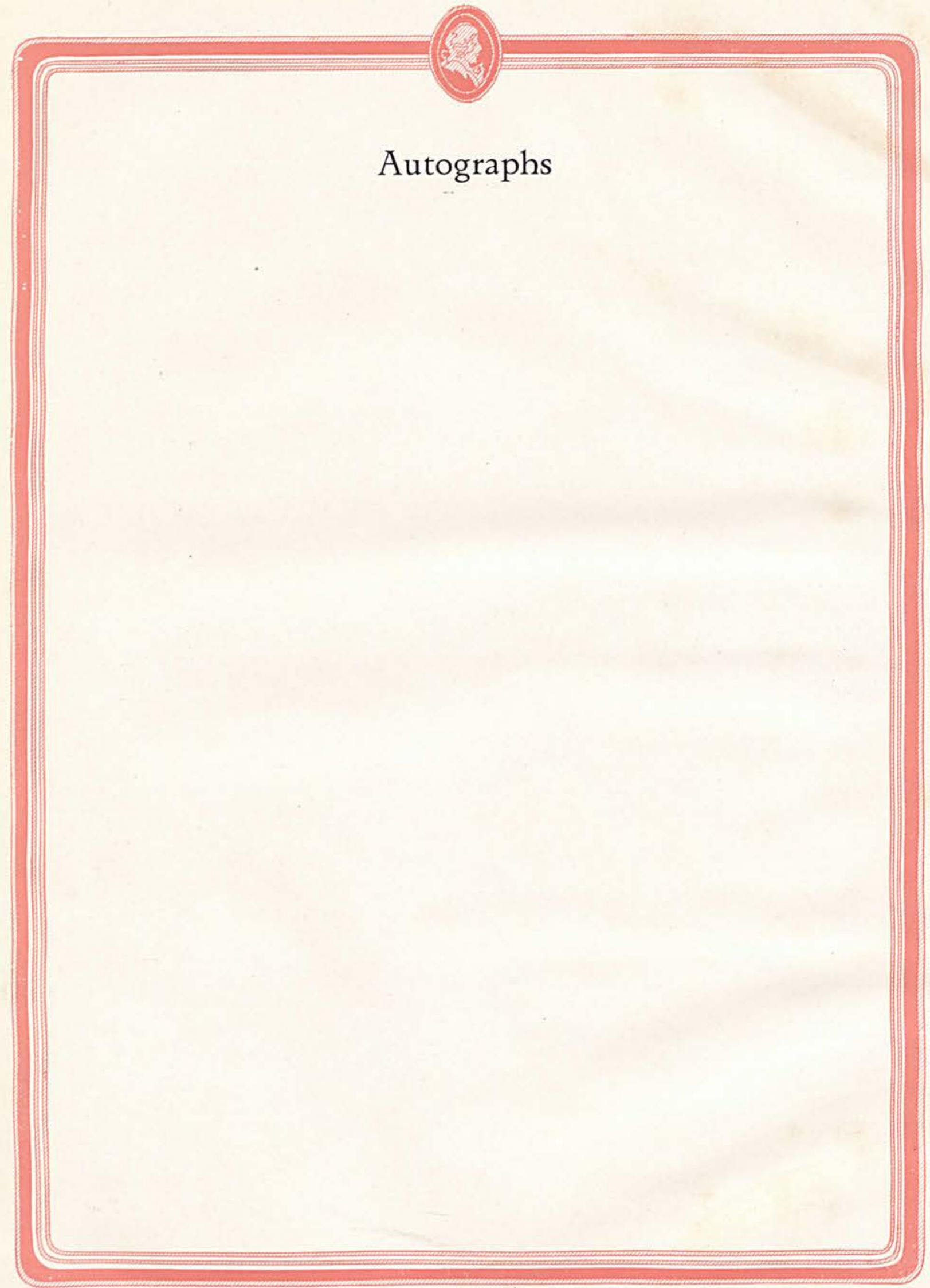




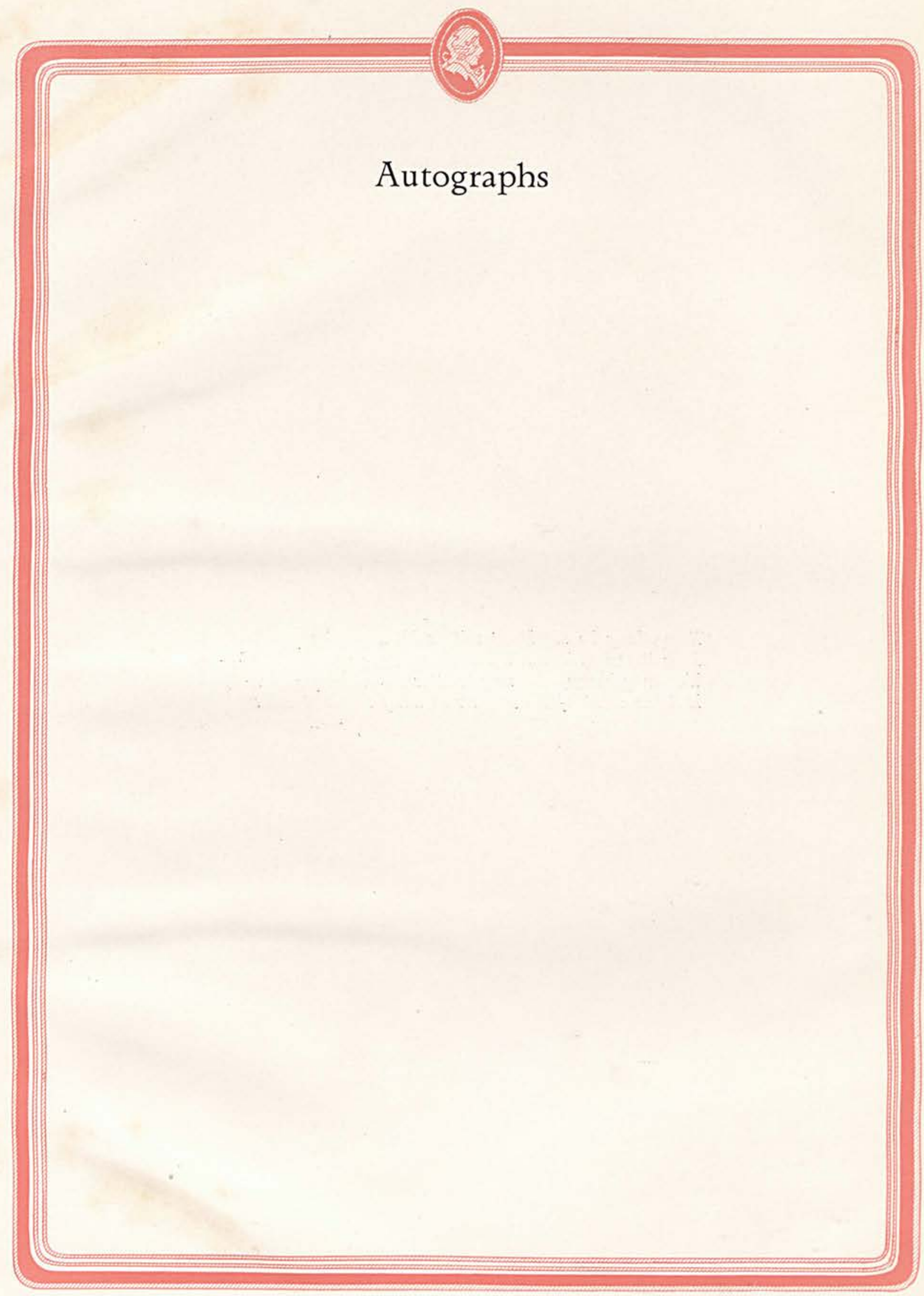

Page One. Hundred and Forty-three 
"Long, long be my heart with such memories filled! Like the vase, in which roses have once been distilledYou may break, you may shatter the vase if you will, But the scent of the roses will hang round it still."

- Thomas Moore. 


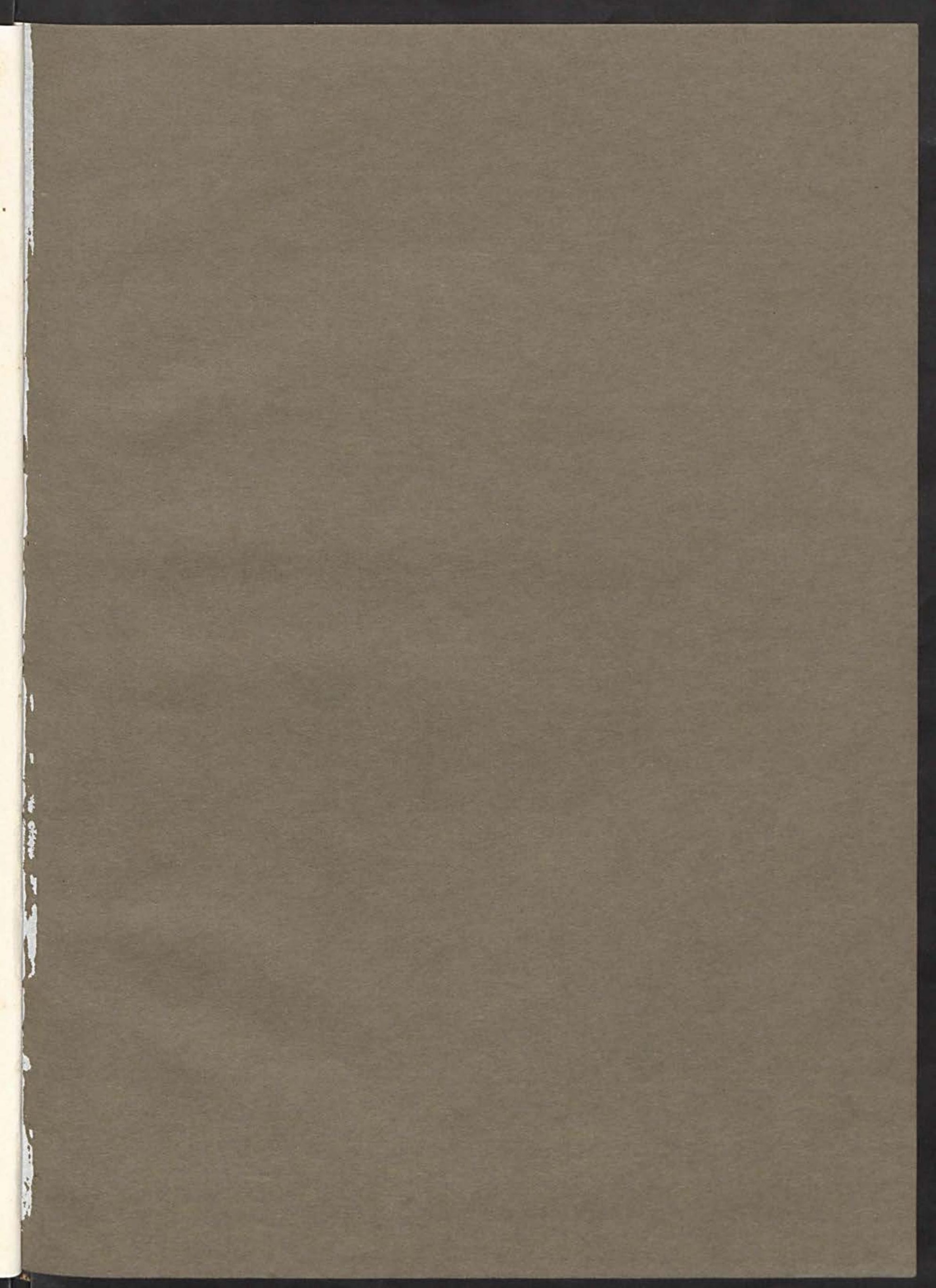




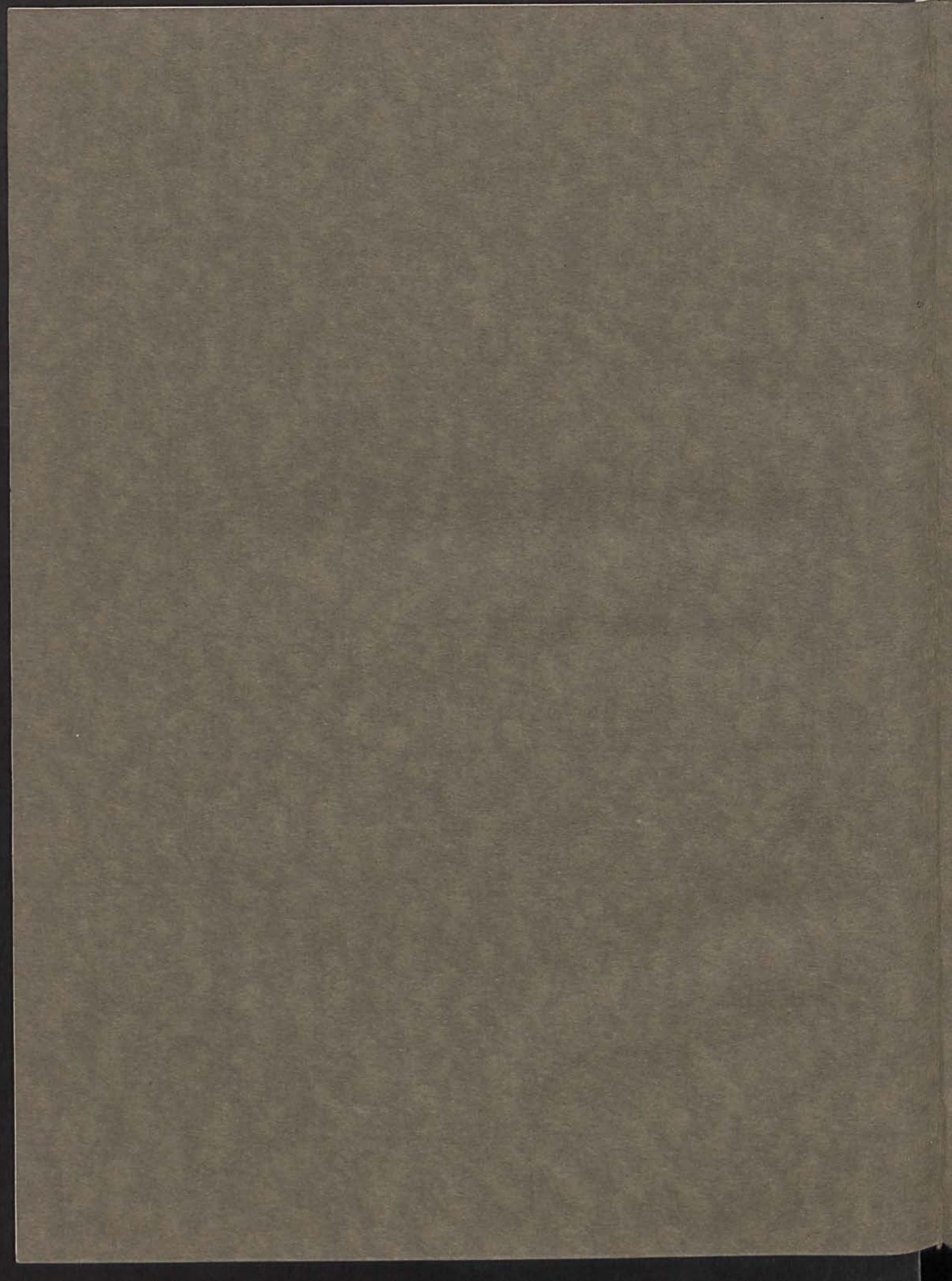


